Estudos sobre Macau

e outros orientes 



\title{
Estudos sobre Macau e outros orientes
}

\author{
Monica Simas \\ (organizadora) \\ DOI: 10.4322/85-99829-93-6
}

\section{Paulistana \\ $\sim$ Editora}

São Paulo, 2017 
Revisão e normatização: Adélia Maria Mariano da S. Ferreira

Projeto gráfico: William de Paula Amado

Dados Internacionais de Catalogação na Publicação - CIP

S598e SIMAS, Monica (org.)

Estudos sobre Macau e outros orientes / Monica Simas, organizadora. São Paulo: Paulistana, 2017.

$318 \mathrm{p}$.

ISBN 978-85-99829-93-6

DOI: $10.4322 / 85-99829-93-6$

1. Literatura. 2. Língua Portuguesa. I. USP. Grupo de Estudos Porta Macau: literaturas, línguas e culturas. II. SIMAS, Monica. III. Título.

CDU 82: 806.90

Catalogação elaborada por Maria José O. Souza (CRB 8/5641)

Nenhuma parte desta publicação pode ser reproduzida ou transmitida por qualquer processo eletrônico, mecânico ou fotográfico, incluindo fotocópia, xerocópia ou gravação, sem a autorização prévia e escrita da Editora.

As informações presentes nos textos aqui publicados são de inteira responsabilidade do seu respectivo autor.

Todos os direitos desta edição reservados à

\section{Paulistana $\sim$ Editora}

Editora Paulistana Ltda.

http://www.editorapaulistana.com.br [2017] 

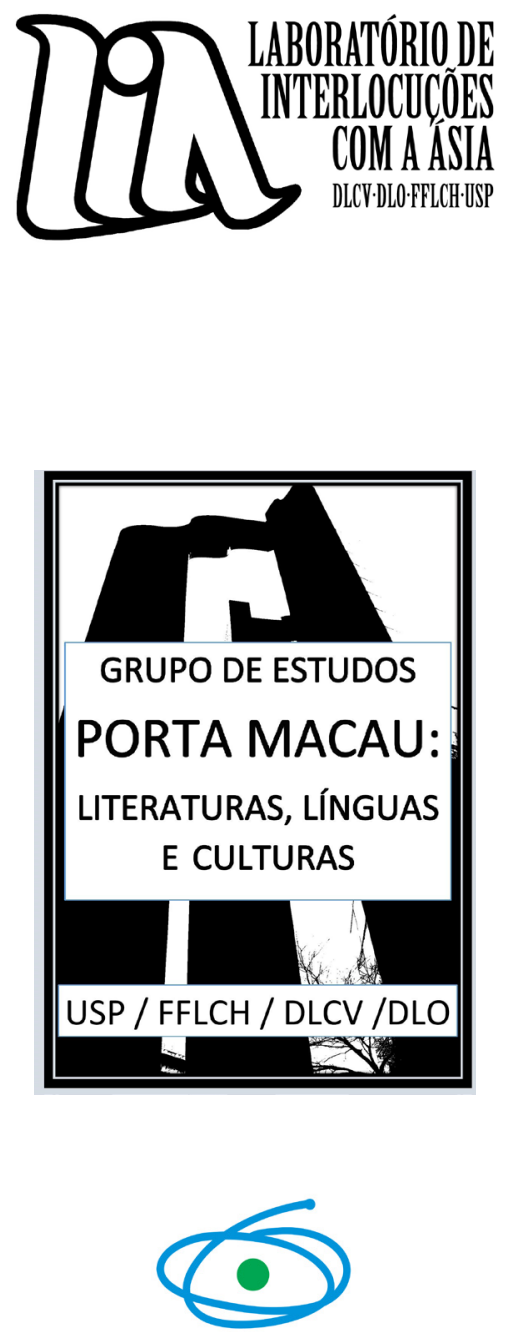

CAPES 


\section{Comissão Gientífica}

Ana Paula Laborinho

(Instituto Camões - Universidade de Lisboa, Portugal)

Fabrício Possebon

(Universidade Federal da Paraíba - UFPB)

Márcia Manir Miguel Feitosa

(Universidade Federal do Maranhão - UFMA)

Maria Elvira Brito Campos

(Universidade Federal do Piauí - UFPI)

Maria Lúcia Abaurre Gnerre

(Universidade Federal da Paraíba - UFPB)

Yao Jingming

(Universidade de Macau, China)

Eliza Atsuko Tashiro Perez

(Universidade de São Paulo - FFLCH/USP) 


\section{Sumário}

Apresentação - 09 -

Monica Simas

Confúcio e o fim da filosofia: análise do capítulo IX do Tratado da Piedade Filial traduzido por

Joaquim Guerra (1984) - 16 -

Antonio José Bezerra de Menezes Jr.

Um testemunho de inéditas modalidades de inculturação Ante Litteram. A ação missionária dos jesuítas na China da Dinastia Ming nas Cartas do Pe. Matteo Ricci - 24 -

\section{Piero Ceccucci}

As redes afro-asiáticas e suas interações culturais com os reinos ibéricos: marfins e mercadorias orientais no Brasil e no México - século XVIII - 53 Jorge Lúzio

Macau: uma literatura plural? - 68 -

\section{Monica Simas}

Oriental(ized) Portuguese-Anglophone litteratura, culture, and colonial stereotypes - 95 - 
Wenceslau de Moraes, suas obras e o serviço exterior português na Ásia - 111 -

Sérgio Pereira Antunes

No descanso eterno entre lápides e epitáfios:

São Miguel Arcanjo e Consolação - 128 -

Maria Célia Lima-Hernandes

Roberval Teixeira e Silva

Goa e Macau: às margens do macrossistema literário de língua portuguesa - 169 -

Hélder Garmes

Museus e ruinarias: orientalismo indiano na poesia de Alberto Osório de Castro - 184 -

Duarte Drumond Braga

Os paclé (portugueses) em narrativas goesas de língua portuguesa ou o "mimetismo regrado" - 201 -

Everton V. Machado

A carnavalização hiperbólica da Macau setecentista num soneto de Bocage (c.1789) em prol da figura

do ouvidor Lázaro da Silva Ferreira - 224 -

Rogério Miguel Puga

A dor que deveras sente - 260 -

Carlos Morais José

Pintar Macau e a Ilha dos Amores: José Rodrigues

e Luís de Camões (Intermedialidades) - 280 -

Isabel Pires de Lima 


\section{Apresentação}

Com a intenção de marcar os 500 anos de contatos entre Portugal e China, em 2013, o Grupo Porta Macau: literaturas, línguas e culturas, certificado pelo CNPq (Conselho Nacional de Desenvolvimento Científico e Tecnológico), promoveu o I Colóquio Internacional do LIA/FFLCH/USP (Laboratório de Interlocuções Asiáticas da Faculdade de Filosofia, Letras e Ciências Humanas da Universidade de São Paulo) - Portugal-China: 500 anos: mudanças, desafios e contrastes -, reunindo especialistas em torno de um estudo comum e multidisciplinar, o oriente, como um tópico comum e constante nos discursos da cultura europeia. A maior parte dos resultados aqui apresentados são fruto desse encontro e da evolução que as pesquisas tomaram. Espaços como Goa, Macau e Timor, entre outros, passaram a ter relevância ímpar às interfaces culturais de uma geografia que não se deu em continuidade terrestre, mas sim como rota importante das vias marítimas que se desenvolveram desde as Navegações. Muito recentemente, a República Popular da China anunciou a criação de uma plataforma - As Novas Rotas da Seda -, buscando desenvolver as relações entre o sudeste asiático marítimo, Portugal e os países de língua portuguesa. Assim se observa que aqueles antigos caminhos não foram ofuscados, mas fortalecidos na construção de novas conexões para este século XXI.

Apesar da importância do estudo sobre os contatos entre Portugal e o oriente, no Brasil os orientalismos são ainda um campo de pesquisa recente. Tanto os orientalismos quanto as si- 
nologias compõem uma grande tradição nos estudos das Ciências Humanas, em países como Inglaterra, França e Estados Unidos, e os estudos portugueses, firmemente estabelecidos no Brasil, podem oferecer uma contribuição única a esse campo do conhecimento. Imagens da China, da Índia, do Sudeste Asiático e doJapão se espalharam por toda a Europa, via Portugal, e passaram a compor um quadro relevante e particular na circulação econômica e simbólica da rede que se formou com os diversos contatos.

O I Colóquio Internacional do LIA/FFLCH/USP foi um dos primeiros eventos no âmbito universitário brasileiro que procurou estabelecer uma troca de informações inéditas, sustentar pesquisas que vêm sendo realizadas há mais de dez anos, com escasso material, pelos vários investigadores, além de possibilitar o conhecimento de documentos raros ou de estreita circulação.

Os pesquisadores, em sua maioria, mantêm uma cooperação contínua desde 2008, ano em que, em Lisboa, no decorrer do Colóquio Internacional Macau na Escrita e Escritas de Macau, a Professora Ana Paula Laborinho, atual Presidente do Instituto Camões, liderou a formação do Grupo Writing Macau, com a intenção de produzir encontros contínuos que pudessem minimizar os efeitos da fragmentação dos estudos acerca do orientalismo português. Em 2009, logo um ano depois, Rogério Puga organizou a I Conferência Internacional dos Estudos de Macau, na Universidade de Macau, ampliando as investigações sobre as relações luso-orientais. Em 2010, Piero Ceccucci desafiou os pesquisadores a aprofundarem os estudos acerca dos imaginários de Macau e do oriente, envolvendo a missionação e as literaturas de língua portuguesa, no evento Quarto Centenário da morte do Padre Matteo Ricci. Em 2011, David Brookshaw, da Universidade de Bristol, incitou todos ao debate sobre as "pena-insularidades", ou seja, 
sobre o escrever o oriente e o ocidente em português e/ou inglês. Depois de 2013, o LIA deu continuidade a esses encontros; em 2015, o Grupo Pensando Goa realizou um congresso voltado aos estudos de Goa e, neste ano de 2017, o recém-certificado Grupo de Estudos de Timor Leste prepara mais um evento internacional. Dessa forma, o leitor terá em mãos uma seleção de textos que se desenvolveram a partir dos debates que surgiram ao longo desses encontros e através dos contatos que se foram estabelecendo entre os diversos pesquisadores, também uma pequena amostra do que tem sido realizado em encontros menores do Grupo de Pesquisa Porta Macau: literaturas, línguas e culturas no âmbito das atividades do LIA.

Do conjunto de textos, no campo da sinologia, Piero Ceccucci investiga o sentido e o valor moral, filosófico e antropológico do termo inculturalidade, segundo a recente definição do Papa Bento XVI, que acabou por reabilitar a perspectiva universalista posta em ato por Matteo Ricci, na sua missionação, expressa em 54 cartas de sua autoria, a partir das relações que estabeleceu com a corte chinesa. Bem mais próximo temporalmente, a extensa obra do padre jesuíta Joaquim Guerra foi objeto de estudo da pesquisa de Antonio Meneses, que, no seu texto, examina a ironia na perspectiva da Ratio Studiorum, articulada aos conceitos de agudeza e discurso engenhoso. O exemplo de análise recai sobre as Notas Críticas da tradução dos clássicos chineses feita pelo jesuíta durante a sua estadia em Macau.

No campo da literatura, a Região Administrativa Especial (RAE) de Macau, como lugar plural, no qual diferentes culturas se distinguem e ao mesmo tempo se misturam, é abordada no meu texto com o objetivo de se definir um contorno amplo e plausível aos estudos literários. As comunidades de falantes de pelo menos três línguas - a portuguesa, a chinesa, a inglesa - li- 
gam-se historicamente de maneiras particulares à região, engendrando sistemas literários fluidos e únicos. Procura-se apresentar as condições de produção e de recepção da literatura produzida nas últimas décadas do século XX e início do século XXI. Já Hélder Garmes considera o contexto em que literaturas periféricas como as de Goa e de Macau podem ter mais sentido ao serem analisadas a partir da noção de macrossistema literário de lingua portuguesa, formulada por Benjamin Abdala Junior em seu artigo "Terra morta e outras terras: sistemas literários nacionais e o macrossistema literário da língua portuguesa", publicado no ano 2000, na revista Veredas, de Portugal. Além de questões conceituais, sempre presentes nos estudos dessas literaturas, o modo como as culturas se confrontam e negociam, o olhar dirigido ao outro, muitas vezes em função de meras projeções de alteridades, é analisado por David Brookshaw e por Everton Machado. David Brookshaw mostra, no seu trabalho, como estereótipos atribuídos aos portugueses pelos discursos anglófilos invadem cenas de filmes americanos para caracterizar o macaense, enquanto que Everton Machado analisa como o termo indo-português "pacló" indica um grau de ambivalência na representação do homem e da mulher portuguesas na literatura em português de Goa. A questão colonial parece suscitar matizes de identificação dentro das dinâmicas social e urdidura intercultural, representadas nas obras de vários autores, como Vimala Devi, Orlando Costa e Maria Elsa da Rocha, entre outros.

Nos espaços que ficam nas margens do império sempre houve escritores de destaque cujas presenças passam a fundir-se com os imaginários da terra. $\mathrm{O}$ texto de Duarte Braga esclarece certos aspectos do fenômeno orientalista português ao examinar a produção do poeta português Alberto Osório de Castro (1868-1946), apontando certo exotismo de cor local representado pela mobilização 
de uma herança ligada a Goa e Timor, bem como influências culturais de outros impérios, e Carlos Morais José debruça-se sobre hipóteses de decifração do sentido poético da obra de Camilo Pessanha. A partir da descoberta das emendas efetuadas pelo poeta, nos poemas da revista Centauro, em volume encontrado em Macau, o autor levanta, primeiro, a possibilidade de se estabelecer uma edição definitiva da obra de Camilo Pessanha com o trabalho coletivo de editores e, segundo, a possibilidade de a pesquisa poética se dar pelo epíteto que lhe atribuiu Mário de Sá Carneiro - o Grande Ritmista - na esteira da celebração musical verlainiana. Em relação aos deslocamentos que o próprio contexto colonial forjou, o trabalho de Rogério Puga contextualiza a produção do soneto "Um governo sem mando, um bispo tal" (c.1789), do escritor português Manuel Maria Barbosa du Bocage (1765-1805), dedicado a Macau e publicado em prol da política e da figura do ouvidor e governador interino Lázaro da Silveira Ferreira. Através do conceito de carnavalização de Mikhail Bakhtin, as estratégias literárias são analisadas em função das relações íntimas que se estabelecem gradualmente entre história, literatura e antropologia ao longo do século XVIII. Sérgio Pereira Antunes caracteriza as circunstâncias do conturbado momento em que Portugal viveu a invasão napoleônica, a independência do Brasil e a guerra civil entre absolutistas e constitucionalistas, culminando num importante papel que a Marinha Portuguesa iria tomar. As obras do oficial da Marinha Portuguesa Wenceslau de Moraes - Traços do Extremo Oriente e Paisagens da China e do Japão - são, hoje, consideradas fundamentais tanto pelos elementos culturais locais descritos quanto pelo seu interesse pela literatura japonesa.

Sem dúvida, a circulação simbólica que as rotas do império formaram encontra, na importante pesquisa de Jorge Lúzio, 
um lugar único para os cruzamentos de imaginários de Macau, localizados no Brasil. O seu texto mostra parte da produção artística em marfim dos espaços coloniais asiáticos do Império português, verificando contrastes e confluências estéticas de tradições culturais locais inseridos nas representações cristãs. As derivas da viagem, do mítico canto de Camões ecoando na obra de artistas até a contemporaneidade, em suas intermedialidades, foi o caminho percorrido por Isabel Pires de Lima ao identificar o diálogo estreito de José Rodrigues, um dos nomes maiores da cena plástica portuguesa contemporânea, com a literatura, em especial com Camões e a epopeia.

Por fim, é apresentado aos leitores um estudo de campo original, de Roberval Teixeira e Silva e Maria Célia Lima-Hernandes, baseado na teoria da sociolinguística interacional, no qual os discursos didáticos presentes nos materiais pedagógicos da língua portuguesa como língua materna, utilizados na RAE de Macau, são analisados em função de se verificar a presença e circulação de ideologias. Os autores partem do pressuposto de que o discurso da sala de aula é construído por interações (microcosmo) que espelham e criam valores, ideais, preconceitos, mitos, estereótipos, padrões, os quais motivam e permeiam as relações sociais (macrocosmo). Os autores observam como os vários materiais didáticos podem ser o lugar do encontro e desencontro entre sujeitos, línguas e culturas que, por questões históricas, sociais e econômicas, estão em contato na RAE de Macau.

Dessa forma, o livro ocupa-se de Macau em sua largueza, nas formações sociais e culturais do seu ambiente, nas relações entre passado e presente e, principalmente, nos cruzamentos que a literatura fundiu, tematizou ou pôs em perspectiva. Foram acrescentadas notas aos textos que já foram publicados em outros meios devido ao longo caminho até esta publicação. 
Contudo, sou convicta de que esta é uma coletânea rara, essencial aos que quiserem se introduzir nesse grande movimento de interlocução com a Ásia.

Monica Simas

Simas, Monica. Apresentação. In: Simas, Monica (Org.). Estudos sobre Macau e outros orientes. São Paulo: Paulistana, 2017. p. 9-15. 


\section{Confúcio e o fim da filosofia: análise do capítulo IX do Tratado da Piedade Filial traduzido por Joaquim Guerra (1984)}

\section{Antonio José Bezerra de MENEZES JR. ${ }^{1}$}

As traduções dos Clássicos Chineses feitas pelo padre jesuíta português Joaquim Angélico de Jesus Guerra (1908-1993), em contraste com as célebres traduções do pastor escocês James Legge (1815-1897), que segue a ortodoxia neo-confuciana de Zhuxi (朱喜, 1130-1200), procuram revelar sentidos filosóficos mais profundos em sentenças excessivamente trivializadas. Para isso, apoia-se no sofisticado aparato linguístico proporcionado pelo seu Dicionário Chinês-Português de Análise Semântica Universal (Guerra, 1981), no qual compilou diversos léxicos chineses antigos, recuperando muitos significados raros.

Um bom exemplo disso podemos encontrar no capítulo IX do "Manual da Piedade Familiar" (朱喜 Xiào Jing), atribuído ao filósofo Zeng Zi (曾子, 505-436 a.C.) e incluído no Quadrivo-

1 Professor do Curso de Chinês da Faculdade de Filosofia, Letras e Ciências Humanas da Universidade de São Paulo, Brasil.antonio.menezes@usp.br 
lume de Confúcio (Guerra, 1984). Nesse texto em particular, ao contrário das demais traduções nas quais Joaquim Guerra trava um intenso debate com James Legge, o tradutor português afirma não ter cotejado o seu trabalho com outras traduções. A razão principal disso é que o referido tratado não foi incluído na coleção "The Chinese Classics” (Oxford, 1861-1872), de James Legge, que Joaquim Guerra estudou detidamente, mas foi incluído apenas na grande coleção Sacred Books of the East (volume III, 1879), editada por F. Max Muller (1823-1900), à qual o sinólogo jesuíta não obteve acesso.

Vejamos agora o seguinte trecho do capítulo IX do "Manual da Piedade Familiar", na tradução de Joaquim Guerra:

故不愛其親而愛他人者, 謂之悖德 ; 不敬其親而敬 他人者, 謂之悖禮。以順則逆, 民無則焉。不在於 善, 而皆在於凶德。雖得之, 君子不貴也。

Se alguém não ama os seus Pais, mas ama a outras pessoas, chama-se a isso uma virtude pervertida. Não respeitar os Pais e respeitar a outros é uma perversão de relações. Se nessas coisas naturais, se põe escândalo, o povo não terá que imitar. Se não se tem o bem à vista, mas só maus exemplos, embora goze de favor, o Homem digno não lhe dá valor. (GUERRA, 1984, p. 949)

Essa passagem é assim traduzida por James Legge:

Hence, he who does not love his parents, but loves other men, is called a rebel against virtue, and he who does not revere his parents, but reveres other men, is called a rebel against propriety. When (the ruler) himself thus 
acts contrary to (the principles) which should place him in accord (with all men), he presents nothing for the people to imitate. He has nothing to do with what is good, but entirely and only with what is injurious to virtue. Though he may get (his will, and be above others), the superior man does not give him his approval. (LEGGE, 1879, p. 479)

Na recente tradução de Rosemont Jr. e Ames (2009), o sentido varia pouco:

It is for this reason that to love others while not loving one's parentes is depravity (de), and to respect others while not respecting one's parentes is a sacrilege (li). To base the norms to be followed (shun) upon such perversity would leave the people without any standards. No decency is to be found in this-only decadence (de). Even though such persons might enjoy a measure of sucess, exemplar persons (junzi) would not esteem them." (ROSEMONT JR.; AMEs, 2009, p. 110-111)

No início desse trecho, Confúcio reafirma que, sendo o respeito e o amor aos pais o princípio da Piedade Filial, na falta disso, a ordem moral da sociedade estará comprometida, ainda que exista uma ordem política visível. ${ }^{2}$ A conclusão do trecho, porém, é que aparece trivializada nas traduções inglesas: "o homem de caráter nobre (君子 jūnž̃) não aprova o governante injusto” (LEGGE, 1879) ou “o homem de caráter nobre (君子 jūnzî) não

2 Também podemos notar aqui um eco da crítica do Confucionismo às doutrinas rivais do Moísmo e do Legismo. 
estima pessoas imorais mesmo que tenham sucesso" (ROSEMONT JR.; Ames, 2009). Em outras palavras, afirmar que o justo reprova o ímpio é por demais trivial. Considerando o contexto de uma sociedade decadente e de um poder político corrompido e corruptor, é que Joaquim Guerra apresenta a sua tradução na qual o homem de caráter nobre (君子 jūnzî) nada deve estimar daquilo que eventualmente obtiver (cargos ou favores) sob pena de desviar-se da norma moral (道 dào).

Nas traduções inglesas, o texto prossegue fazendo a distinção entre o homem corrupto e o homem de caráter nobre (君子 jūnzî), mostrando as qualidades deste último de forma idealizada:

君子則不然, 言思可道, 行思可樂, 德義可學, 作 事可法，容止可觀，進退可度。

It is not so with the superior man. He speaks, having thought whether the words should be spoken; he acts, having thought whether his actions are sure to give pleasure. His virtue and righteousness are such as will be honored; what he initiates and does is fit to be imitated; his deportment is worthy of contemplation; his movements in advancing or retiring are all according to the proper rule. (LeGGe, 1879, p. 480)

Exemplary persons (junzi) are nothing like this. They are concerned that what they say be credible, and what they do be a source of enjoyment (le). Their excellence (de) and sense of appropriateness (yi) is to be esteemed and they are to be emulated (fa) in what they do. In their bearing and deportment they are to be looked up 
to, and in their undertankings they are to be taken as a standard. (Rosemont JR.; Ames, 2009, p. 111)

Joaquim Guerra, porém, considera justamente a hipótese contrária, no caso de o homem de caráter nobre (君子 jūnž̃) desviar-se da norma moral (道 dào) e, portanto, não realizar a sua humanidade, trazendo, com isso, graves consequências para ele mesmo e para a sociedade:

君子則不然, 言思可道, 行思可樂, 德義可學, 作 事可法, 容止可觀, 進退可度。

Se o Sábio se não realiza, será que as palavras e os propósitos ainda têm sentido? Ainda haverá prazer no que se faz? O ideal da virtude ainda se poderá honrar? E no que se faz ainda haverá uma norma? Avançar e recuar poderão ser ainda um procedimento avisado? (GUERRA, 1984, p. 949)

Essa tradução é perfeitamente possível tomando-se os caracteres 然 (rán) e 可 (kě), ambos no sentido (5), tal como Joaquim Guerra registra em seu dicionário: 


\begin{tabular}{|c|l|}
\hline 然 & $\begin{array}{l}\text { 1) Sim, certamente, deveras, tal qual, realmente, } \\
\text { assim mesmo; 2) Mas, contudo, todavia, nesse } \\
\text { Jen.6ih }\end{array}$ \\
rán & $\begin{array}{l}\text { 4) Aparência, como, tal como; 5) Ser, existir, ente, } \\
\text { entidade; 6) Suf. De advérbios de modo; 7) Apro- } \\
\text { var, aquiescer, embora. (GuERRA, 1981, p. 327) }\end{array}$ \\
\hline Xhau.0db & $\begin{array}{l}\text { 1) Habilidade, hábil, ser capaz de, poder, po- } \\
\text { der ser, possível, viável, viabilidade, permitido; } \\
\text { 2) Aval, autorização, anuir, anuência, aprovar, } \\
\text { aprovação; 3) Aguentar, tolerar; 4) Convenien- } \\
\text { te, apropriado, Acomodado, afeito, habituado, } \\
\text { calhar bem, acertar, acertado, acerto; 5) Como? } \\
\text { Pode lá ser? 6) Nesse caso, mas só que. (GuERRA, } \\
\text { 1981, p. 779) }\end{array}$ \\
\hline
\end{tabular}

O problema da linguagem que perde o sentido retoma a questão da "retificação dos nomes", um dos temas fundamentais em Confúcio, como podemos ler em Os Analectos XIII, 3: "Quando os nomes não são corretos, a linguagem fica sem sentido. Quando a linguagem fica sem sentido, nenhum assunto pode ser resolvido" (LEYs, 2005, p. 69).

Concluindo o capítulo IX do "Manual da Piedade Familiar", diz Confúcio:

以臨其民。是以其民畏而愛之, 則而象之。故能成 其德教, 而行其政令。

No governo do povo, começa-se pelo respeito para chegar ao amor. Se o bom exemplo se evidencia, então se 
poderá realizar a educação na virtude, e exercer um governo autêntico. (GuERRA, 1984, p. 949)

Confúcio coloca no governo do povo os mesmos princípios que formam a Piedade Filial: o respeito e o amor. Embora pareça pequena, a virtude da Piedade Filial é de importância fundamental, pois um pequeno desvio no início poderá mais tarde resultar em grandes desvios: o governo que nega a justiça e o intelecto que nega a verdade.

Somente a educação na virtude, essência do Confucionismo, é que irá produzir um governo autêntico e não um desgoverno que ofende ao Céu e que se transforma ele próprio em castigo até que o Mandato do Céu (天命 tiān mìng), conforme a historiografia tradicional chinesa, seja retirado do governante ímpio e dado ao governante justo.

\section{Conclusão}

Todas as traduções aqui apresentadas do capítulo IX do "Manual da Piedade Familiar" são perfeitamente cabíveis, diferentemente do caso de Analectos VII,11, no qual a singular tradução de Joaquim Guerra é indubitavelmente a mais acertada (Menezes JR., 2013, p. 93-103). Porém a tradução do sinólogo português possui o mérito de recolocar o pensamento confuciano em termos sempre mais agudos.

Confúcio buscava a sabedoria no passado. Não se definia como um inventor, mas um transmissor da verdade revelada nos clássicos da antiguidade (Analectos VII, 1 e VII, 19). Desse modo, o sábio que não se realiza (por descumprir os deveres elementares da piedade) representa o abandono dessa vocação e a sua hegemonia no plano cultural terá como consequência o fim da filosofia. 


\section{Referências}

Guerra, Joaquim A. de Jesus. Dicionário Chinês-Português de Análise Semântica Universal. Macau: Jesuítas Portugueses, 1981.

Guerra, Joaquim A. de Jesus. Manual da Piedade Familiar. In: Quadrivolume de Confúcio. Macau: Jesuítas Portugueses, 1984. p. 915-979.

Legge, James. The Hsiao King. In: Muller, Friederich Max (Ed.). Sacred Books of the East. Oxford: Claredon, 1879. v. III, p. 483-522.

Leys, Simon. Os Analectos. Tradução, apresentação e notas de Simon Leys (Pierre Ryckmans). São Paulo: Martins Fontes, 2005.

Menezes JR., Antonio José Bezerra de. Joaquim Guerra S.J. (1908-1993): Releitura universalizante dos Clássicos Chineses. São Paulo, 2013. Tese (Doutorado em Letras) - Faculdade de Filosofia, Letras e Ciências Humanas, Universidade de São Paulo, Brasil, 2013. Disponível em: <http://www.teses.usp.br/teses/ disponiveis/8/8150/tde-13032014-124801/pt-br.php>. Acesso em: 10 jan. 2015.

Rosemont JR., Henry; Ames, Roger T. The Chinese Classic of Family Reverence: A Philosophical Translation of the Xiaojing. Honolulu: University of Hawai'i Press, 2009.

Menezes JR., Antonio José Bezerra de. Confúsio e o fim da filosofia: análise do capítulo IX do Tratado da Piedade Filial traduzido por Joaquim Guerra (1984). In: SimAs, Monica (Org.) Estudos sobre Macau e outros orientes. São Paulo: Paulistana, 2017. p. 16-23. 


\title{
Um testemunho de inéditas modalidades de inculturação ante litteram: a ação missionária dos jesuítas na China da Dinastia Ming nas Cartas do Pe. Matteo Ricci
}

\author{
Piero CECCUCCI \\ Xitai, ${ }^{2}$ depois de ter efetuado uma difícil \\ viagem de $80.000 l i^{3}$ para o Oriente, veio \\ à China para fazer amigos. Quanto mais \\ profundo é o conhecimento que ele tem \\ das doutrinas e da amizade, tanto mais sente \\ a necessidade de procurar amigos e tanto \\ mais de mantê-los.
}

1 Docente de Língua e Literatura Portuguesa e Brasileira na Universidade de Florença. Tem uma produção científica rica e diversificada com mais de 110 títulos, que compreende livros, ensaios, artigos, etc. e de que se podem salientar os trabalhos sobre Cesário Verde, José Saramago, Fernando Pessoa, a poesia portuguesa de hoje (Ana Hatherly, Sophia de Mello Breyner Andresen) e os trabalhos sobre Clarice Lispector e Jorge Amado, como assim sobre a acção missionária dos Jesuítas no Brasil, na China, etc. Traduziu para o italiano, com um grande êxito editorial, O Livro do desassossego e sempre de Pessoa, em dois volumes, a poesia orto-eteronima; piero.ceccucci@unifi.it

2 Li Xitai é o nome honorífico com que os chineses chamavam ao Matteo Ricci. Xitai quer dizer "Mestre do grande Ocidente".

3 O li é uma unidade de medida de distância, que corresponde a uns 500 metros. 


\begin{abstract}
$[\ldots]$
Eu, Yingjing, tão pouco capaz, em jovem estava mergulhado nos livros: não tive tempo para viajar à procura de amigos [...]. Ao ver que Xitai passou montes e atravessou mares para fazer amigos, sinto-me tão envergonhado! Então refleti sobre o seu ensaio e cada vez mais convenci-me de que mentalidade e doutrina do Oriente e do Ocidente são idênticas.
\end{abstract} (Feng Yingjing $\left.{ }^{4}\right)$

Após um século de viagens e descobrimentos portugueses, que "abriram o mundo ao mundo", e de uma sucessão rapidíssima de encontros, "por mares nunca de antes navegados" CAMÕES, 1972), com universos completamente desconhecidos, mas espantosos pelas suas belezas naturais exóticas e artísticas, entre os quais in primis o da China, propaga-se na comunidade eclesial católica do século XVI, com uma humanitas e pietas inéditas e exemplares, o debate sobre a função da criação e, por conseguinte, sobre o mistério da salvação. De resto, o extraordinário cenário do universo humano e natural das Índias, com a China e oJapão como ponto de chegada, que de forma inesperada, mas providencial, se ia então abrindo à evangelização, não deixava dúvidas sobre a necessidade da acção missionária de salvação de todos os homens, vistos como filhos de Deus.

Como corolário desse processo, era justamente a Companhia de Jesus que maior impulso dava ao debate e adequava a

\footnotetext{
4 Feng Yingjing (1555-1606), "letrado", amigo de Matteo Ricci, mandou imprimir em Pequim no ano de 1601 o Tratado da amizade, inserindo nele a 9 de fevereiro de $1601 \mathrm{um}$ seu prefácio, de que foi tirada a epígrafe, acima citada.
} 
sua prática evangelizadora a essas concepções, com um projecto missionário realmente inovador.

$$
* * *
$$

Como sabemos, a Companhia de Jesus constituíra-se formalmente em 1540 com a aprovação da Regra mediante a bula Regimini Militantis Ecclesiae, emanada pelo Pontífice Paulo III, a 27 de setembro do mesmo ano. Já no mês de abril de 1541, a pedido do rei de Portugal, D. João III, os primeiros Jesuítas guiados pelo Padre Francisco Xavier embarcaram para as Índias, onde só chegaram em maio do ano seguinte, devido a numerosas tempestades.

Os jesuítas, enquanto neófitos de uma ordem há pouco formada, eram verdadeiramente animados por uma fé extraordinária e apaixonada, que se revelava e manifestava de imediato através de uma atividade incansável de proselitismo e de evangelização, defendendo e propagando o Catolicismo no mundo, mas mantendo as tradições culturais autóctones. No Oriente, Francisco Xavier obtinha resultados surpreendentes graças à prodigiosa intensidade e novidade metodológica da sua acção missionária.

Isto vem explicar o extraordinário fenómeno da rápida difusão da Companhia em terras de Oriente, sustentado por um fluxo abundante e contínuo de jovens missionários cheios de entusiasmo. Foi um movimento que haveria de se prolongar ao longo do tempo, ao ponto de, um século mais tarde, o historiador italiano da ordem, Padre Daniello Bartoli (1608-1685) escrever: "Se si mandassero alle Índie quanti ne han desiderio, scemerebbe, si può dire, per metà la Compagnia in Europa" (BARTOLI, 
1825, p. 39) . Com efeito, quer antes, quer depois da "Grande Missão" de 1574 - durante a qual quarenta e um Jesuítas embarcaram para as Índias com o Padre Visitador Alessandro Valignano - segundo o Catálogo dos Padres e dos Irmãos que foram enviados para as Índias por ordem de cad'ano, entre 1541 e 1600, partiram 427 missionários da regra de Santo Inácio. Esses empenhavam-se com todas as suas energias na concretização da sua missão, que se baseava não no aniquilamento das culturas pré-existentes com que entravam em contacto, mas, num processo ante litteram de inculturação - cujo conceito filosófico-religioso analisaremos daqui a pouco - mas na recuperação e utilização, se não in toto pelo menos em parte, de elementos que podiam ser plasmados de forma a neles inserirem a palavra evangélica e a fé cristã.

De resto, para os jesuítas era quase um desafio e, como tal, aceitavam-no, conhecendo plenamente a tarefa que os esperava. Aliás, tinham a convicção - que de resto constituía a trave mestra da sua performance pedagógico-missionária -, de que só através de uma postura verdadeiramente respeitadora de modelos comportamentais ancestrais, poderiam suscitar o interesse junto de povos evoluídos quer em termos civilacionais quer em termos de riqueza de tradições religiosas. Tratava-se de uma performance que se realizava de modo muito coerente e claro em todas as terras do Oriente, sobretudo na China, cuja organização político-social e económica, e nível civilizacional alcançados eram superiores aos de todos os outros Estados. Nesse sentido, Serafim Leite, o grande historiador da acção missionária jesuita no Brasil, parece glosar:

5 "Se se mandassem para as Índias todos os que nos apresentam pedido, a Companhia ficaria com menos de metade dos seus efectivos na Europa" (Bartoli, 1825, p. 39). Su questo argomento si veda anche Gian Carlo Roscioni (2001). 
Ordem nova, protótipo das Ordens religiosas modernas, fundada com o fim determinado de propunhar, na Europa, pela unificação do espírito cristão e latino, in quavis mundi plaga, onde se travassem batalhas por Deus [e pela Igreja Católica, s.n.r.] os Jesuitas, sobretudo [...], logo se assinalaram em todas as regiões, onde flutuasse a bandeira das Quinas, como senhora e hospede de honra. No Oriente S. Francisco Xavier assombrou o Mundo com as suas maravilhas. (Leite, 1938, X)

Assim, o padre jesuíta, Matteo Ricci (nascido na cidade de Macerata em 1552 e falecido em Pequim em 1610), num atento processo de inculturação, prudente e decisivo, fazia de tudo para entrar imediatamente em sintonia, por um lado com a metodologia evangelizadora dos inacianos, por outro lado com a mentalidade dos nativos, chegando até a abdicar dos seus trajes de estrangeiro, muito mal vistos pelos chineses, e edificando casas e igrejas de acordo com a estrutura arquitectónica e as cores do urbanismo chinês, abandonando o estilo europeu e fazendo com que a missão, como lugar real de residência, passasse o mais despercebida possível. Como ele recorda:

E porque ja tinhamos determinado de deixar os nomens de bonzos, que entre os Chines he tido em tão vil e baixo estado, e tomar nome de letrados e pera isto conforme aa licença que nos tinha deixado o padre visitador, fizemos creser as barbas e o cabelo ate orelha, e iuntamente haviamos de usar de um vestido particular, que os letrados usã no tempo das visitas e não do que primeiro usavamos de bonzos. (RICGI, 2001, p. 217) 
As medidas adoptadas, que aos nossos olhos poderão parecer precauções tácticas, correspondiam verdadeiramente a uma específica estratégia de pensamento, ou se quisermos, a uma efectiva preocupação ideológica; porque era real a necessidade, mas também o sentimento, com vista à evangelização, de uma adequação aos modelos culturais locais, aceitando-os e deles se apropriando nas modalidades e nos comportamentos da vida quotidiana. De resto, os missionários jesuítas, graças à sua longa e orientada educação recebida nos colégios, eram estimulados a plasmar uma sua própria forma mentis das categorias de pensamento específico que, harmonizando-se no conjunto dos seus confrades, encontravam a sua justifcação teórica e comportamental nos textos fundadores da Companhia, como as Constituições e os Exercícios Espirituais, onde o tema da missão surge, sem sombra de dúvida, como o que melhor caracteriza a identidade jesuíta.

Assim, os missionários que operavam no Império Celeste, através de performances mutáveis e adaptadas aos acontecimentos e às circunstâncias sociais, iam ultrapassando com êxito desconfianças e oposições. A esse propósito, como sublinha Horácio Peixoto de Araújo num seu excelente estudo "os efeitos de tal mudança não se fariam esperar, manifestando-se, especialmente, ao nivel da facilitação das relações com os mandarins e de um acrécimo de credibilidade junto das populações" (ARAújo, 2000, p. 109).

Era, sem dúvida alguma, a atitude mais correcta e certeira no processo de inculturação que, favorecendo a abertura no sentido de um intercâmbio cultural, acabaria por facilitar a entrada dos Padres nas mais altas instâncias do poder chinês e fornecer um decisivo impulso à evangelização. Através da actividade missionária, assim concebida e posta em prática, a Companhia 
não só se abria para o mundo, glorificando Deus, como também implementava uma nova forma de monaquismo, abandonando a clausura para modelar e impor uma inédita "ascese intramundana", de um itinerarium a Deum ${ }^{6}$ individual no apostolado entre as gentes do mundo.

Por outro lado, na China, o nível de civilização era decididamente superior ao de qualquer outro território extraeuropeu. Se abdicarmos do pressuposto que leva a associar o nível de civilização com o desenvolvimento e o progresso da ciência e da técnica, apanágio da Europa ocidental, instrumento de poder e colonialismo, teremos forçosamente de reconhecer que na China de então, no pensamento e nas artes, bem como na organização e no exercício do poder, se tinham alcançado níveis de excelência, até mesmo em relação ao modelo europeu. E isso aparece nitidamente desde as primeiras reflexões sobre o Império de Meio que o já recordado Pe. Visitador Alessandro Valignano fez, quando se encontrou pela primeira vez, em setembro de 1578, em Macau:

El reyno de la China es tan diferente de todos los demás reynos y naciones que hay en todo este Oriente, assí en la qualidad de la gente y sus costumbres, como en la qualidad y fertilidad de la tierra, que no tiene quasi nenguna semejança con los otros, mas a todos excede; y es la cosa más principal y más rica que hay en todo el Oriente. [...] Es la más pacifica y bien governada tierra que hay en lo descubierto; y es mucho de meravillar,

6 A leitura dos textos fundadores da Companhia de Jesus permite-nos conhecer não só as origens e as intenções da missão, mas também aceder à própria essência das categorias jesuítas. A missão não é apenas um meio para ampliar o reino de Deus, mas uma modalidade de salvação pessoal. 
specialmente siendo de gentiles, que no tienen luz de la verdad ni de la doctrina de Dios, que es la que enseña el verdadero modo de govierno. (Valignano, 1944, p. 214-215)

O Padre Visitador tinha-se apercebido logo da enorme importância estratégica da China, embora não subestimasse as graves dificuldades e os riscos reais que os missionários corriam ao entrar na terra dos chineses. Todavia, tendo em conta as extraordinárias potencialidades que se abriam à evangelização, tinha solicitado os Padres Michele Ruggeri e Matteo Ricci, que na altura se encontravam em Goa, para que se transferissem para Macau e se dedicassem ao estudo da língua e da cultura chinesa, em vista à entrada naquele Pais.

Além disso, os próprios padres missionários no dito processo de inculturaçaõ, tanto cuidadoso quanto decisivo, fizeram tudo para entrarem logo nos modelos de comportamento dos nativos.

De fato, no Império Celeste, foi o Matteo Ricci que, exemplarmente, ensinou os colegas para agirem com a prudentia et pietas do "bom pastor", do padre amorável e do irmão diligente. Sobretudo, ciente que esse processo de evangelização apesar de o mesmo assentar numa relação de reciprocidade, o Ricci monstrou-se, desde os primeiros contactos, atento e respeitoso em relação às tradições e aos modelos culturais enraizados e, certamente, não "bárbaros", que nada tinham a invejar aos europeus, pondo a tónica do projecto de evangelização nos mecanismos de composição harmoniosa de um encontro de culturas capazes de dialogarem entre si e de se abrirem a uma influência recíproca e profícua.

Ao mesmo tempo, porém, soube tirar proveito dos seus conhecimentos tecnológicos e científicos superiores, que des- 
pertavam vivo interesse junto das autoridades locais e centrais. Especialmente no que se referia às ciências matemáticas e astronómicas, bem como a alguns instrumentos, de que o nosso grande apóstolo da China era profundo conhecedor, ${ }^{7}$ graças à óptima educação que recebera em Roma, adquirindo assim grande estima e consideração, junto dos mandarins e "letrados" chineses e na própria corte imperial de Pequim, não só pelos conhecimentos humanísticos e científicos que mostrava possuir, mas ainda pela capacidade de construir esferas metálicas, quadrantes solares, prismas, relógios, canóculos (a elaboração do seu primeiro Mapamundi é de finais de 1584), que depois doava às autoridades ou a pessoas influentes no entourage político-administrativo local.

De fato, durante a sua formação humanística no Colegio Romano, que podemos equiparar aos nossos Institutos Superiores Universitários, ${ }^{8}$ teve a grande sorte de encontrar como professor o célebre matemático e astrónomo Cristoforo Clavio, autor do tratado In spheram Ioannis de Sacro Bosco Commentarius, 1570, conhecido simplesmente como Esphera e que foi também um dos artífices da reforma do Calendário Juliano, promulgada pelo papa Gregório XIII em 1582.

Entrar, portanto, no imaginário e na cultura compósita desse imenso país e, ao mesmo tempo, utilizar a sua superioridade tecnológica e científica, representava para o missionário maceratese a condição imprescindível para abrir uma brecha na

\footnotetext{
7 Lacouture (1991, p. 261).

8 Na verdade, adaptado ao modelo do Ateneu de Paris, o Colégio Romano foi outorgado pelo Papa Paulo IV como centro de estudos superiores no ano de 1556. Tinha nascido como "Escola de gramática, de humanidades e de doutrina cristã", em que podiam entrar os jovens "omnis conditionis", de todas as condições sociais, provindos de diversas nações europeias. Por isso foi titulado de "Collegium Universale - Omnium Nationum Seminarium". (Vd. Scartezzini, 2009, p. 38).
} 
postura dos Chineses, orgulhosamente conscientes do valor da própria civilização, com vista a um projecto missionário duradouro e profícuo.

Nisso emerge, de forma evidente, a extraordinária capacidade do jesuíta a adaptar-se e submeter-se - sendo ponto assente os fins da evangelização e os fundamentos da doutrina católica - às diferentes circunstâncias e situações quer espaciais quer temporais em que vinha a encontrar-se durante a prossecução da sua missão.

$$
\text { *** }
$$

Portanto, o ponto central da ação missionária no plano teórico e prático do Padre Matteo Ricci, que constitui aliás o próprio fundamento do seu sucesso em terras chinesas, baseia-se essencialmente numa abordagem empática, que ultrapassa - ainda que inconscientemente - qualquer processo de interculturação, com a milenária cultura de um povo, como ele mesmo defende, naturalmente predisposto ao bem. Trata-se, antes, visto e definido com a mais correta terminologia filosófico-antropológico-eclesial de hoje, de um original e acabado modelo de inculturação, segundo a codificada, afinal de contas, recente aceção formulada pelo Sínodo dos Bispos italianos em 1977 e formalizada pelo Papa João Paulo II.

Ultimamente reproposta pelo pontífice Bento XVI, a inculturação fundamenta-se, de facto, em formas de fecundo diálogo entre os povos, que em referência à ação missionária dos Jesuítas na China, encontra no Padre Matteo Ricci ${ }^{9}$ o pioneiro e

9 Recorde-se que, no quarto centenário da sua morte, a 10-11 maio de 2010, se celebrou, também na Universidade de Florença, a figura do célebre apóstolo da China, 
o testemunho mais incisivo e significativo do encontro paritário de culturas tão diferentes e tão distantes. Ele, de fato, emerge assim como personagem singular que soube realizar um inédito estilo de evangelização, através de uma metodologia científica e uma estratégia pastoral baseadas, por um lado, no respeito dos usos sãos do lugar e, por outro, na consciência que o verbo cristão podia ainda mais valorizá-los e completá-los, tirando dele, o próprio movimento missionário, de reflexo, alto enriquecimento espiritual e novo impulso; uma personagem, portanto, de elevada estatura moral e inteletual, cuja metodologia evangelizadora, tenazmente seguida e defendida, se plasmou como modelo de diálogo entre culturas, de respeito e de colaboração, de encontro e de profícuo, sugestivo intercâmbio entre dois mundos que se esforçavam por compreender-se.

O nosso jesuíta, de resto, encorajado também pelos antigos escritos filosóficos da tradição cultural dos "letrados" dos quais aflora, como extrema síntese de pensamento pedagógico-religioso, uma famosa máxima moral de K’ung fu tzu, conhecido no Ocidente com o nome de Confúcio, relatada num fragmento dos Lü jü (Diálogos) - que afirma: "Podemos aprender a ser sábios de três maneiras. A primeira é aprender a refletir e é a melhor. A segunda é a imitação, e é a mais fácil. A terceira é confiar na experiência, e é a mais dolorosa" - (o jesuíta, dizia eu) indica com o exemplo e com a palavra, sobretudo escrita, mas também com a sua postura metodológica, fruto de atento estudo e de experiência, aos seus confrades e à Instituição os percursos de sapiência confucianos que, apoiando-se na tradição cultural do

com um Congresso Internacional, com ampla repercussão cultural, intitulado "Quarto Centenário da Morte do Padre Matteo Ricci (1552-1610), do qual em 2012 saíram as respetivas Atas com a chancela da Sociedade Editora Dante Alighieri di Roma. 
Império de Meio, oportunamente recebidos e repropostos pelos evangelizadores, mediante a reflexão, o exemplo e a maturação humana, teriam contribuído para levar o homem chinês para o homem novo cristão. Deste modo, Li Madou (transliteração chinesa de Matteo Ricci) acabaria por se propor como importante testemunho e reconhecido protagonista de um fenómeno que, ontem como hoje, é central no Cristianismo e na obra de evangelização, e que encontrou a posteriori na inculturação, nas últimas décadas do século passado, como acima referido, uma acabada estruturação concetual. Esta, em termos antropológico-filosóficos em oposição à aculturação, entendida negativamente como modalidade de absorção e dissolução destrutiva das diversidades étnico-culturais dos vários povos, define-se nitidamente como

[...] abordagem missionária-pastoral-cultural que reconhece a diferenciação das culturas e escolhe encaixar nelas a semente do Evangelho de forma a, na base de uma mútua fecundação (entre semente e terreno fértil), se realize uma autêntica encarnação e regeneração benéfica do próprio Evangelho no novo contexto. (RAVASI, 2009, p. 27)

Essa escolha pastoral, teológica e cultural, sentida aliás como enriquecimento recíproco espiritual entre os diversos atores, encontrou no Papa João Paulo II, como acima recordado, o seu mais convicto defensor, ao ponto de, num discurso proferido no Quénia em 1980, afirmar: “A inculturação será realmente um reflexo da encarnação do Verbo, quando uma cultura, trasformada e regenerada pelo Evangelho, produz a partir da sua própria tradição expressões originais de vida, de celebração, de pensamento cristão" (Giovanni PaOlO II). 
A intervenção do Papa polaco foi determinante para recolocar no trilho da ortodoxia as várias diatribes sobre a ação missionária dos jesuítas na China - em primeiro lugar de Matteo Ricci -, não só confirmando o decreto de tolerância sobre os Ritos chineses de Pio XI ${ }^{10}$ e acabando com a chamada "Questão dos Ritos", ${ }^{11}$ que durante séculos tinham moldado a Igreja chinesa, mas reconhecendo mesmo a correção teológico-doutrinal da estratégia evangelizadora dos "inacianos".

A inculturação, enfim e como já dito, não pode ser redutivamente vista como tática missionária ou, no máximo, como estratégia pastoral, mas deve ser assumida como estrutural à evangelização, operada pelos Jesuítas, e à própria fé cristã, como sapientemente tinha compreendido e posto em prática, ante litteram, Matteo Ricci, com uma anticipação de quatrocentos anos, na formulação concetual de uma específica ação missionária. De facto, tornando-se chinês entre os chineses, ele conseguia, graças a uma fé intrépida e firme, naquela missão considerada impossível aos demais, abrir as portas do grande Império de Meio, fechado em si mesmo e hostil ao estrangeiro, avançando com convicção e prudência ao encontro com o outro, portador de uma mensagem de irmandade, de paz e de ascenção social e espiritual que viria a encaixar-se, vivificando-a, na tradição mais fecunda do pensamento confuciano, professado e seguido pelos "letrados".

10 Pio XI em 1939 tinha acabado com a "querelle" relativa aos ritos chineses, promulgando um decreto de tolerância, embora reconhecesse deles só o sentido social.

11 Recordamos aqui, incidentemente, que o Papa Clemente XI em 1704 tinha chegado ao ponto de promulgar um decreto de condenação dos ritos confucianos, tolerados pelos jesuitas, reforçado e agravado em 1715 com a bula Ex Illa Die, vindo proibir claramente, como não ortodoxa no plano teológico-doutrinal, a metodologia evangelizadora dos jesuitas e do próprio Ricci. 
Decerto ter-lhe-ão servido o conhecimento da língua e da escrita chinesa ${ }^{12}$, cujo estudo tinha iniciado imediatamnete após a sua chegada a Macau (1582), sabendo-as tornar suas para cruzar o diálogo paritário e construtivo com a doutrina confuciana, numa troca de saberes aberta e respeitosa. Não é por acaso nem sequer neutral que, neste sentido, ele se-autodefina um "confuciano ocidental" 13. Bastará, a esse propósito citar o Tratado da Amizade (1595) e as Vinte e cinco sentenças (1605), escritos por Matteo Ricci diretamente em língua chinesa, não tanto para conferir vestes orientais à mensagem evangélica, mas sobretudo para lhe dar maior profundidade comunicativa.

Mas, para compreendermos plenamente e melhor do nosso jesuíta a postura, o pensamento, as aspirações, mas também os improvisos temores e abatimentos, relacionados com os êxitos do seu incansável labor, não podemos não colocar em primeiríssimo plano, entre os seus escritos mais significativos, as Cartas - ainda que grande parte delas perdidas ou nunca chegadas ao destino, por causa dos inúmeros naufrágios das embarcações do tempo - hoje disponíveis num belo volume ${ }^{14}$, em que podemos encontrar, sob o signo da inculturação, as mais convictas teses de uma metodologia de evangelização esforçada e difícil, mas frutuosa e, sobretudo, precursora dos tempos.

Escreve a este respeito de Nanchang em 1595 ao Padre Duarte de Sande S.I.:

12 "Eixo da nova estrátegia era o domínio da língua do pais que o acolhia, para poder interagir sem necessidade de intérpretes e de ser capaz de estudiar as crenças religiosas, a cultura, as tradições, os ritos e os hábitos de vida, bem como as regras que regulavam as normais relações interpersonais". (Vd. RicCARdo Averini, p. 37).

13 Vd. Wang Suna e Filippo Mignini (2010, p. XIX).

14 Vd. nota 7 do presente capítulo. 
Como V.R. ve, himos muito cresendo no credito e no respeito com os Chinas; o qual he summamente necessario assi pera poder ter entrada com os grandes, como tambem pera que tenhão em estima nossa sancta ley e doutrina. Porque, posto que não seia de nossa profissão andar buscando honras, todavia nesta terra, onde a lei de Nosso Senhor não he conhecida e do credito e reputaçã que terão os pregadores desta sagrada doutrina depende, em hum certo modo, tam bem a reputação da mesma lei, he necessario quanto ao exterior que nos acomodemos com os costumes e modo de proceder dos Chinas. E bem se comessa a enxergar quanto isto emporta: porque ata agora com hirmos mais humildemente no esterior e sermos tidos por bonzos, fomos sempre tratados como gente baixa e de nenhum ser, nem numca podemos ter entrada com os mandarins e outras pessoas de conta; e agora com esta mudança que fizemos ja comesamos a ter entrada com todos e somos tratados delles com muita honra e cortezia: quanto mais que pera nos não fazer mal esta honra e credito, que agora comesamos a ter entre os Chinas, nos fez Nosso Senhor passar primeiro por doze anos continuos em Xauquin (Zaoqing) e em Xaucheo (Shaozhou) tantas desonras, abatimentos e afrontas e tantas perseguições. (Ricci, 2001, p. 264-265)

$$
* * *
$$

O volume em questão assumido por mim quase como repertório rico de acentos de inculturação, editado pela chancela 
da Quodlibet de Macerata (2001), ${ }^{15}$ terra do Ricci, recolhe um corpus de 54 cartas, mais uma, a quinquagésima quinta, datada de 12/11/1607 e endereçada ao Padre Gaspar Fernandes, provincial da Índia em Goa, colocada em apêndice. Esta, enfim, não é uma verdadeira carta, mas o resumo de uma passagem de uma missiva que não chegou ao destinatário.

Como é óbvio, para os fins hermenêuticos que me propus, não farei uma análise estilistico-estrutural das cartas, nem irei examinar as várias questões temáticas nelas desenvolvidas. Ater-me-ei exclusivamente ao argumento escolhido, o de apreender e pôr em evidência a metodologia evangelizadora de Ricci, como aflora dos textos e que, mostrando tirar proveito dos ensinamentos recebidos nos anos de estudo e de formação no Colégio Romano, acima recordado ${ }^{16}$, de facto, "como a experiencia é a que melhor ensina" (Gouves, 2001, p. 100), adota, no encontro com o outro, uma originalíssima estratégia de diálogo e generosa atenção para com a cultura milenária com a qual entra em contato. Inaugura, afinal, formas de inculturação eficazes e sobretudo personalíssimas; audazes para o tempo, tanto que, como acima indicado, pelas outras ordens (domenicanos e franciscanos) - entrados na China no século XVII ${ }^{17}$ - depois da sua morte - talvez também com uma ponta de disfarçada inveja, consideradas não

15 Na verdade, o texto das cartas do nosso missionário foi extraído, salvo pouquíssimas variantes, do segundo volume das Opere storiche del Pe. Matteo Ricci S.I., editadas com organização do Comité para as honras nacionais com prolegómenos, notas e quadros do Padre Pietro Tacchi Venturi S.I., Macerata, Stab. Tip.Giorgetti, 1911-1913.

16 Vd. nota 10 do presente texto.

17 Os primeiros missionários dominicanos entraram na China em 1631, enquanto os franciscanos - se exceptuarmos o periódo da sua presênça na China de 1294 a 1368, em que se salienta a figura de frey Giovanni da Montecorvino (1247-1328), durante a Dinastia Yuan - chegaram ao Celeste Império da Dinastia Ming em 1633. 
completamente ortodoxas, criticadas por muitos e longos anos, provocaram a inopinada e ruinosa condenação do método ricciano por parte do Santo Ofício romano em 1704. A consequência foi que, alguns anos mais tarde, o imperador Kangxi que, embora em 1692 tivesse promulgado um decreto de tolerância para os missionários ocidentais, irritado pelo comportamento arrogante dos delegados pontifícios cada vez mais irreverentes perante ele, começou a tornar-se rígido nas suas posições. Instaurou-se assim de novo um clima de incomunicabilidade extremamente aceso entre a China e a Igreja Católica, que induziu em 1724 o Imperador Yongzheng, sucessor de Kangxi, a emanar o edital de expulsão de todos os "bárbaros" europeus. Fecharam-se desse modo, definitivamente, aos missionários ocidentais, as portas que Ricci, com o seu saber, o seu amor e a sua ductilidade performativa, tinha conseguido abrir. A desconfiança e os medos perante o estranho-estrangeiro voltaram a erguer barreiras entre os dois mundos, com alternadas oscilações até hoje.

E, no entanto, como sublinhámos acima várias vezes, as Cartas abriam um amplo campo à discussão, quer interior quer exterior da própria Companhia, constituindo um precioso testemunho de uma sagaz ação missionária, que Ricci, com o seu saber e a sua dedicação de pastor, tinha positivamente sortido efeito de instaurar com o universo chinês, no diálogo e na recíproca confrontação, vencendo a desconfiança de governadores e mandarins, até obter a benevolência pessoal do próprio Imperador, que o tinha chamado à corte, embora sem o admitir nunca na sua presença nem lhe falando diretamente.

Está fora de questão que tenham sido o seu forte sentimento religioso, a sua fé e o amor a Deus e ao próximo a induzir o jesuíta a uma particular atenção com este povoadíssimo e sempre amado reino, onde com imensos sacrifícios ia recolhendo riquís- 
simos frutos espirituais de salvação, absorvendo-lhe a língua, cultura e estilo de vida. Escreve assim de Zhaoqing em 10/1 1/1585:

Como homem, que aqui me parece que irei acabar os poucos dias que Deus me concederá de vida, vou-me acomodando e afeiçoando à terra quanto posso, e cada dia vou podendo mais, porque já falo correntemente a língua e comecei pregar aos cristãos na nossa igreja, e daqui em diante temos de abrir a porta também a alguns gentis que o desejem. De igual modo fiz com ao ler e escrever as suas letras, que são alguns milhares; porque vou intendendo muitos livros sozinho et todos com uma ajuda qualquer. (RICGI, 2001, p. 109)

As Cartas ricciane propõem-se, portanto, como precioso documento emblemático da fenomenologia do encontro e do diálogo e como texto eloquente de análise de suasiva metodologia comunicativa, capaz de derrubar barreieras de medos ancestrais, de desconfianças e de incomunicabilidade.

Com efeito, eles desenham uma pessoal e natural inclinação de Ricci para estabelecer relações de atenção e de afeto com o estrangeiro, até à abnegação e anulação do seu próprio eu, renunciando a grande parte dos sonhos, com os quais vem sendo construída a identidade pessoal. Decidindo "fazer-se enteiramente China", para comunicar com este "outro mundo", com os homens "de diversas nações", ele não hesita em despojar-se de todos os sinais exteriores da sua identidade de filho da Europa (língua, alimentos, roupas, costumes, formas de relação social), chegando a ocultar até muitos signos e símbolos, que considera estritamente não essenciais, da sua fé religiosa. 
Quase todas as cartas que compõem o volume descrevem, mesmo a intervalos irregulares, por causa da muito precária circulação das missivas, um modo de ser, de se colocar e de se propor do missionário que, por índole ou consciente escolha, desenvolve e aperfeiçoa um método de evangelização, levando, com a máxima, infinita humildade, até ao extremo do humano possível, a capacidade de se negar - excetuando os princípios da fé - como homem religioso imbuído de doutrina ocidental, pronto a abrir-se aos saberes do outro, aprendendo-lhes a língua e lendo e estudando os livros dos Letrados confucianos.

A 8 de março de 1608, escreve ao Preposto General da Companhia, Pe. Claudio Acquaviva:

Por esta causa, faço tudo o que puder para que todos os nossos Padres estudem muito bem os livros da China e procurem saber compor; porque na verdade, coisa que não se crê facilmente, faz-se mais na China com os livros do que com palavras [...] e deve-se proceder nesta via com muita maturidade para ser esta gente sábia nas coisas do mundo, alertada e suspeitosa dos forasteiros; acima de tudo, deve-se considerar bem os sujeitos que nestes principíos se enviam, que sejam prudentes e de bons estudos, porque tratamos com gente exercitada nos seus livros, e não facilmente lhes poderiamos vender chumbo por prata. (RicCI, 2001, p. 470-471)

Numa outra carta, alguns meses depois, a 23 de agosto de 1608, pontualiza desse modo o seu pensamento ao Pe. Fabio de Fabii que se encontra em Roma: 
Com tudo isto, pregamos aqui continuamente a nossa santa lei com palavras e com livros, e está entre os letrados em muito boa reputação, porque tratamos aqui todos com muito respeito, tanto grandes como pequenos; e de forma a que nenhum se queixe de nós, todo o dia estou na sala recebendo gente que nos vem visitar, e depois disto vou-lhes retribuir a visita, às vezes, oito ou dez mihas de distância. (Ricci, 2001, p. 501)

Todavia, a carta mais importante, entre as que nos chegaram, referentes à metodologia ricciana é a que foi enviada, a 15 de fevereiro de 1609, ao Viceprovinciale da Compagnia, Pe. Francesco Pasio, que constitui, um ano antes da morte do autor, uma espécie de revisitação testamentária de toda uma vida, passada ao serviço de Deus e da Igreja, levando o dom da palavra evangélica à amadíssima "nação" chinesa.

Ao mesmo tempo, ela configura-se também como um legado espiritual e operativo, para os seus sucessores, para que não abandonem o seu exemplo e a sua metodologia de apostolado, propondo-os aos confrades, aos fiéis e ao mundo chinês como sinal e convite à continuidade, para que:

[...] quando morrermos nós que fomos os primeiros, e quando também morrer este rei, a mesma coisa deve ter um seguimento com a divina graça. E assim o meu parecer agora seria que, como nesta corte estamos com tanto crédito e com estima não só daqueles que estão fora da corte, mas também dos mandarins da corte, e embora seja falso que o rei nos queira muito bem e que às vezes fala connosco, devemos nós aproveitar para pôr mais padres em diversas partes da China, para que, 
quando faltasse aos nossos este apoio do favor que se dá a eles da nossa parte, mantidos pelo erário do rei, ficasse a China cheia dos nossos confrades em segurança sem medo de serem expulsos. [...] O risco de qualquer edital do rei contra nós só existe em duas coisas: uma é manter relações com os forasteiros, e fazer saber fora do reino que somos mantidos e damos e temos informações; a outra é o pregar a lei nova na China. A este segundo nós não podemos obviar, uma vez que é esta a nossa finalidade, se não confiar na divina providência, [...] e da nossa parte fazer esta missão prudentemente e com discrição e com bons livros e boas argumentações, demonstrando aos letrados a verdade da nossa doutrina [...]. E sobretuto neste começo procurar bons cristãos que muita multidão, e se for possível alguns letrados de alto grau e mandarins, que pudessem com a sua autoridade, serenar aqueles que tivessem medo desta novidade. (RICCI, 2001, p. 513-514)

Enfim, continuando, ele resume, teoricamente, com extrema síntese e lucidez, em oito pontos, os elementos fundadores daquela estratégia evangelizadora, que valerá a pena di referir como conclusão do presente trabalho. Com efeito, segundo as convicções metodológicas missionárias de Ricci, nascidas da experiência de trinta anos de obra feita no Império de Meio, a difusão do cristianismo foi-se articulando segundo as seguintes prioridades operativas, que nós, hoje em dia, reconhecemos constituir a própria essência da inculturação.

Realmente, ele diz:

O primeiro motivo [a ter em consideração, n.d.r.] é ver o princípio e o progresso desta missão como muito mi- 
lagroso, e semelhante ao que são próprios das coisas divinas; [...] visto que já vamos contando os cristãos feitos aos milhares [...] e somos estimados não só como homens muito virtuosos, mas também por letrados e de muito valor $[\ldots]$.

O segundo, uma vez que neste reino são muito apreciadas as letras e, consequentemente, as ciências e as argumentações fundadas na razão. [...] E por isto parece ser fácil convencer os principais do reino sobre as coisas da nossa santa fé confirmadas com tanta evidência de raciocínio, e obtendo o consenso das pessoas mais importantes que existem entre elas, será fácil converter todos os demais. [...]

O terceiro, que segue este, é a facilidade que temos de divulgar a nossa santa religião cristã com livros que entram por toda a parte sem impedimento; e assim facilmente se divulgam $[\ldots]$ as coisas mais consideradamente e com mais exatidão do que aquilo que se pode dizer verbalmente.

Quarto: são os chineses de belo engenho natural e aguto, $[\ldots]$ que surpreende todo este Oriente. Por isso, se lhes pudéssemos ensinar as nossas ciências [...] por meio delas levá-los-emos facilmente à nossa santa lei. Quinto: são também inclinados para a piedade, ainda que a outros possa parecer o contrário, porque fui descobrindo isto pouco a pouco. [...] E, examinando bem todos os seus livros, encontraremos neles pouquíssimas coisas contra o lume da razão e muitíssimas conformes a ela.

Sexto: têm bastante facilidade em conservar-se cristãos, os que se podem fazer por causa da grande paz que 
ordinariamente há neste reino [...] E é certo que se a este se pudesse converter o rei e a sua casa real, seraiam eles mesmos a procurar que todos se fizessem cristãos [...], porque se fossem os Chineses cristãos, nunca mais existiriam entre eles as revoltas e as perturbações dos Estados que existem por vezes e que sempre se temem. Sétimo: com isto e com o modo que usámos para tratar com pessoas muito importantes e segundo as suas maneiras corteses, todos os nossos já ganharam o nome de doutos e santos, e creio que devemos conservar isto até o fim; porque, aliás vão aqui muito bons missionários e todos teólogos, não houve ninguém até agora que não atenda mais do que mediocremente às letras da China, uma vez que saber as nossas sem saber as deles não serve de nada; e V.R. verá bem quanto importa este punto nestes inícios. Por mim considero-o mais do que ter feito mais dez mil cristãos, para ser este meu agir favorável e necessário para a conversão universal de todo o reino. Oitavo: com este ponto, quero sublinhar o apoio que temos dos livros dos leitrados da China para as coisas da nossa fé. [...] e como, por meio disto, muitos deles se fizeram cristãos e dão sinais manifestos de ser claramente bons cristãos. (RICCI, 2001, p. 516-520)

A coisa que parece incontrovertível desta longa citação é que o método missionário de Ricci é um cruzar de tantas estratégias e é difícil captar-lhe o nexo unificante sem primeiro enovelar os muitos fios que o compõem, analisando-o um por um: a chegada a Pequim, a permissão imperial, o apostolado através da ciência, o acomodamento, a distinção entre catecismo e doutrina cristã, a diferença entre apostolado direto e indireto, 
a admissão na Companhia dos nativos, o apostolado através dos livros, a frequência de letrados e funcionários.

Todos, porém, tomados no seu conjunto, reconduzem a um único conceito, explicitado no termo "acomodamento"18, que é o elemento caracterizador e central da inculturação. Com efeito, o método do acomodamento, seguido na sua atividade missionária, mergulha as suas raízes no pensamento teologico-pedagogico de S. Tomás de Aquino e de Erasmo de Roterdão. Acomodamento, portanto, não quer dizer, ao enfrentar complexas questões culturais e religiosas, ceder perante as razões do outro renunciando às próprias convicções, mas - no nosso caso específico - suma disponibilidade e vivo espírito de caridade a encontrar um elemento de síntese entre duas diferentes tendências de pensamento, a confuciana e a cristã, que, salvaguardando a essência irrenunciável das questões da fé e da verdade revelada, permita abrir-se à escuta das razões do interlocutor.

No fundo, em toda a ação missionária de Ricci há qualquer coisa de semelhante entre o seu método de evangelização e a catequese dos primeiros séculos do cristianismo, quando ela previa a atenção ao bom que provinha do mundo antigo e a introdução gradual aos mistérios da fé. Gradualidade e ductilidade parecem a estrela polar da ação missionária do nosso jesuíta, que

18 Segundo um modelo proposto pelo psicólogo suíço Jean Piaget e largamente aceitado, existiriam os dois processos de assimilação e de acomodamento, através dos quais os esquemas mentais são enriquecidos mediante a incorporação dos contributos provenientes do ambiente. Estes dois mecanismos são complementares e asseguram a manutenção do equilíbrio entre continuidade e mudança. Por extensão, porém, no sentido político-social e filosófico-antropológico,

a adaptação significa tomar consciência de uma nova realidade, para nela adaptar as suas categorias filosofico-antropológico-religiosas, segundo o pensamento tomista e erasmiano, que constituía um dos fundamentos pedagógicos, ensinados no Colégio Romano dos Jesuítas. 
tem - só para dar um exemplo - com o apóstolo Paulo de Tarso - e o confronto não deve parecer irreverente - surpreendentes pontos de contato e de convergência estratégica, na adaptação do método às situações e à experiência.

Como glossa iluminante, a tudo quanto disse, chegam, como conclusão, as palavras de alta autoridade do Papa Bento XVI, que acabam por encerrar com sapiência e síntese eloquente o presente trabalho:

Não obstante as dificuldades e as incompreensões que encontrou, o Padre Matteo Ricci quis manter-se fiel até à morte, a esta modalidade de evangelização, atuando uma metodologia científica e uma estratégia pastoral baseadas, por um lado, no respeito dos hábitos sãos do lugar, [...] e, por outro, na consciência que a Revelação podia ainda mais valorizá-las e completá-las. E foi mesmo a partir destas convicções que ele, como já o tinham feito os Padres da Igreja no encontro do Evangelho com a cultura greco-romana, imprimiu o seu trabalho sagaz de inculturação do Cristianismo na China, procurando um entendimento constante com os doutos daquele país. (BENEDETTO XVI, 2012, p. 16)

\section{Bibliografia}

Andreotti, Giulio. Un gesuita in Cina (1552-1610). Milano: Rizzoli, 2001.

Catto, Michela; Mongini, Guido. Missioni e globalizzazioni:

L'adattamento come identità della Compagnia di Gesù. In: 
Evangelizzazione e globalizzazione. Le missioni gesuitiche nell'età moderna tra storia e storiografia. Roma: Società editrice Dante Alighieri, 2010. p. 1-15.

D'Elia, Pasquale M. Storia dell'introduzione del Cristianesimo in Cina. In: Fonti Ricciane: documenti originali concernenti Matteo Ricci e la storia delle prime relazioni tra l'Europa e la Cina (1579-1615). Roma: La libreria dello Stato, 1942-1949. 3 voll. Edite sotto il patrocinio della Reale Accademia d'Italia (Edizione nazionale delle opere edite e inedite di Matteo Ricci).

Feng, Yingjing. Prefazione per la stampa dell'Amicizia [1601]. In: Rica, Matteo. Dell'amicizia. Macerata: Quodlibet, 2005.

Fontana, Michela. Matteo Ricci, un gesuita alla corte dei Ming. Milano: Mondadori, 2005.

MieLI, Paolo. Il Vangelo e Confucio: un incontro mancato. Corriere della Sera, Milano, 24 luglio 2012.

Mignini, Filippo. Matteo Ricci. Il chiosco delle fenici. Ancona: Il Lavoro Editoriale, 2004.

Mongini, Guido. Ignazio di Loyola: un illuminato al servizio della Chiesa. Milano: 24 Ore Cultura, 2014. OcchetтA, Francesco. Matteo Ricci, il gesuita amato dalla Cina. Elledici, 2009.

Po-Chia-Hsia, Ronnie. Un gesuita nella città proibita. Matteo Ricci (1552-1610). Bologna: Il Mulino, 2012.

Ricai, Matteo. Catechismo. (Il vero significato di "Signore del Cielo" [1603]. Traduzione dal cinese di Antonio Olmi e Giovan Battista Sun. Bologna: Edizioni Studio Domenicano, 2013. . Descrizione della Cina. Macerata: Quodlibet, 2011. 
. Dieci capitoli di un uomo strano - seguito da - Otto canzoni per manicordo occidentale. Macerata: Quodlibet, 2010. Della entrata della Compagnia di Giesù e Christianità nella Cina. Macerata: Quodlibet, 2000.

\section{Referências}

AraúJo, Horácio Peixoto De. Os Jesuítas no Império da China. O Primeiro Século (1582-1680). Lisboa: Instituto Português do Oriente, 2000.

Bartoli, Daniello. Della vita di Sant'Ignazio [1650]. Torino, 1825. 5 voll.

Benedetto xvi. Messaggio del 6 maggio2009 alla Diocesi di Macerata per le celebrazioni ricciane. In: Ceccuca, Piero (Org.). Quarto Centenário da Morte do Padre Matteo Ricci (15521610. Atas do Colóquio Internacional, Florença 10-11 de Maio de 2010. Roma: Società Editrice Dante Alighieri, 2012. p. 16.

Camões, Luís Vaz de. Canto I. In: CAMões, Luís Vaz de. Os Lusíadas. Lisboa: Editora do Instituto de Alta Cultura, 1972. v. 3.

Ceccucar, Piero (org.). Quarto Centenário da Morte do Padre Matteo Ricci (1552-1610) - Macau e o Oriente nas Literaturas de Língua Portuguesa) - Receios e Seduções. Atas do Colóquio Internacional, Florença 10-11 de Maio de 2010. Roma: Societá Dante Alighieri, 2010.

Dreyfus, Paul. Matteo Ricci: uno scienziato alla corte di Pechino. Milano: S. Paolo, 2006. 
Gouvea, António S. I. Ásia Extrema: Primeira Parte - Livros II a VI. Lisboa: Fundação Oriente, 2001.

Lacouture, Jean. Les Jesuites: les conquérants. Paris: Seuil, 1991.

Leite, Serafim Soares. História da Companhia de Jesus no Brasil. 1938. 10 vol.

Mignini, Filippo; Suna, Wang (Org.). Introduzione. In: Ricai, Matteo. Dieci capitoli di un uomo strano, seguito d Otto canzoni per manicordo occidentale. Macerata: Quodlibet, 2010.

Ravasi, Gianfranco. Matteo Ricci e l'inculturazione. In: Ai crinali della storia: Matteo Ricci fra Roma e Pechino. Torino: Allemandi \& C., 2009.

Rica, Matteo. Dell'Amicizia [1595], Macerata: Quodlibet, 2005.

. Lettere (1582-1609). Macerata: Quodlibet, 2001.

Roscioni, Gian Carlo, Il desiderio delle Indie. Storie, sogni e fughe di giovani gesuiti italiani. Torino: Giulio Einaudi Editore, 2001.

Scartezzini, Riccardo. L'innesto della cultura rinascimentale europea in un contesto confuciano. In: Ai crinali della storia, Padre Matteo Ricci fra Roma e Pechino. Torino: Allemandi \& C., 2009.

Valignano, Alessandro, Historia del Principio y Progresso de la Compañia de Jesus en las Indias Orientales (1542-1564). Ed. de Josef Wicki. Roma: Institutum Historicum S.I., 1944. 
Venturi, Pietro Tacchi. Opere storiche del Pe. Matteo Ricci S.I. Macerata: Stab. Tip.Giorgetti, 1911-1913.

Cencucci, Piero. Um testemunho de inéditas modalidades de inculturação ante litteram: a ação missionária dos jesuítas na China da Dinastia Ming nas Cartas do Pe. Matteo Ricci. In: Simas, Monica (Org.). Estudos sobre Macau e outros orientes. São Paulo: Paulistana, 2017. p. 24-52. 


\title{
As redes afro-asiáticas e suas interações culturais com os reinos ibéricos: marfins e mercadorias orientais no Brasil e no México - século XVIII
}

\author{
Jorge $\mathrm{LU}^{\prime} \mathrm{ZIO} \mathrm{O}^{1}$
}

\section{Girculações em Nova Espanha}

Os estudos sobre as circularidades ${ }^{2}$ e as dinâmicas de comércio e cultura no contexto político dos reinos ibéricos impulsionaram grande parte dos debates que a historiografia colonialista vem discutindo para repensar questões culturais na América lusa e hispânica ${ }^{3}$. Na dimensão dos circuitos marítimos e vínculos mercantilistas do expansionismo europeu - um dos as-

\footnotetext{
1 Doutor em História pela Pontifícia Universidade Católica de São Paulo - PUC SP, é mestre em História pela mesma instituição. Membro do Laboratório de Interlocuções com a Ásia - LIA FFLCH USP e do Grupo Outros Orientes EBA-UFRJ, com Lato Sensu em Cultura e Arte Barroca / UFOP-MG, especialização em Yoga / UniFMU-SP. Docente no Centro Universitário Assunção Unifai - São Paulo; jorgeluzio@hotmail.com

2 De acordo com as abordagens de Russel-Wood (1992).

3 Cf. Gruzinski (2001).
} 
pectos que caracterizam as relações de Portugal e Castela com as suas possessões ultramarinas -, torna-se elementar compreender que as rotas transoceânicas constituíram o quadro econômico que determinou muito do que artisticamente se consumiu e do que foi artesanalmente reproduzido nos espaços coloniais para atender as demandas das elites locais no fascínio pelo exótico e pelos produtos orientais, amplamente comercializados nas naus, nos portos e nas praças das cidades interligadas pelas chamadas grandes navegações, e destas para os principais centros urbanos das unidades coloniais.

Para os portugueses, foi, sem dúvidas, a Carreira da Índia - rota intercontinental que unia Lisboa ao sul da Índia e vice-versa do século XVI ao começo do XIX -, o principal caminho para os intercâmbios estabelecidos entre os espaços coloniais, haja vista o mercantilismo, a integração administrativa, o poder centralizador da Coroa e o trabalho missionário da conversão das almas, alguns dos fatores que alimentaram o Império português, nesse prisma compreendido como uma complexa rede comercial, detentora de uma infinidade de produtos e bens extraídos dos mercados sob o seu domínio, na América, na África e na Ásia.

No contexto hispânico encontra-se o Galeão de Manila, rota comercial que surgiu das pioneiras circunavegações dos espanhóis no Pacífico, como atesta Andrés de Urdaneta (15071568), navegador e religioso agostiniano, a quem fora atribuída a criação do roteiro marítimo de $\mathrm{Cebu}^{4}$, no sudeste asiático, à ilha de Guam, e desta para Acapulco, ligando o Oriente ao México. A viagem era feita pelas grandes naus ibéricas, entre elas os galeões

4 Nas Filipinas. 
que designaram tal rota onde circularam objetos de $\operatorname{arte}^{5}$, porcelanas, sedas, especiarias e demais mercadorias orientais para a Nova Espanha ${ }^{6}$ e, no sentido inverso, fez escoar a prata do México nos mercados asiáticos. Desse comércio floresceu a cidade de Manila como centro do domínio hispânico na Ásia, iniciado em $1565^{7}$ com a chegada dos espanhóis que já encontraram naqueles arquipélagos vínculos comerciais consolidados entre mercados chineses e sultanatos em todo o sudeste asiático, do subcontinente indiano à Indonésia. Memije explica que:

La base comercial del continente americano hace posible el mantenimiento del archipélago filipino. Sólo la contrapartida de la plata mexicana puede alimentar el tráfico de los productos orientales, que sustentan la vida econômica de Filipinas, aun cuando arroje um déficit constante que debe ser suplido por el situado desde Nueva España. Estos galeones, pues, son para los americanos los que lês llevan los cargamentos de mercancias del Oriente. Para Filipinas son embarcaciones que traen pesos mexicanos y peruanos, que constituyen el critério o medida de valor em su território. Los manifestos de los galeones son um verdadero catálogo de productos orientales, que se llevan a México y Perú principalmente. ${ }^{8}$ (Memije, 1992, p. 96)

5 Cf. Durán (2005).

6 Cf, Bayón (1993).

7 Ver Manel Ollé i Rodríguez (Universidade de Barcelona) in "A inserção das Filipinas na Ásia Oriental (1565-1593)", disponível em: <http://www.upf.edu/grimse/_pdf/2_Ollex.pdf>. Acesso em: ago. 2017.

8 Cf. Memije (1992, p. 96). 
É, portanto, numa dimensão teórico-metodológica, importante reconhecer que as redes afro-asiáticas ${ }^{9}$, absorvidas pelos reinos ibéricos são responsáveis pelo grande volume de mercadorias que circularam no Brasil, na bacia platina e em portos importantes da América Latina, como México ${ }^{10}$ e Peru. Assim como os empreendedores comerciantes lusos, os mercadores de Sevilla incentivaram o comércio do Galeão de Manila que, se proporcionou altíssimos lucros aos investidores espanhóis na apropriação das riquezas na Ásia e no México, favoreceu uma notável interação cultural de produtos, conceitos e padrões estéticos vigentes entre os séculos XVI e XVIII, o que incita uma investigação mais criteriosa sobre as relações intracoloniais ${ }^{11} \mathrm{e}$ intraimperiais ${ }^{12}$ das monarquias ibéricas. Um exemplo claro dessas dinâmicas está na iconografia luso-oriental em marfim produzida nas oficinas das ordens religiosas e nos ateliês dos artesãos autóctones em Goa e Macau que criaram as representações cristãs de Jesus, de Maria e dos santos e santas católicos, para efeito de evangelização e, sobretudo, enquanto produto e obra de arte de grande apelo comercial na Europa. A circulação dessas esculturas, nas naus da Carreira da Índia e dos vínculos entre Macau e Cebu, nos galeões de Manila, influenciou a propagação de cultos

\footnotetext{
9 As rotas tiveram, na costa oriental africana banhada pelo Índico, a integração de África com os mercados asiáticos que, comercialmente vinculados, formavam uma ampla e intensa economia marítima.

10 Cf. Bailey (s/d).

11 No contexto português, as relações Brasil e Ásia, no hispânico Manila e México.

12 De acordo com Fabio Pesavento (2009), que classifica as redes de comércio interimperiais em três dimensões básicas de interação de redes: as transimperiais, para transações que envolveram diferentes impérios, podendo ser divididas em extra-imperial, que se dava entre dois impérios, e intraimperial que operava dentro dos limites de um império. Sobre as relações intracoloniais no Império português, tomando como exemplo Brasil e Índia, consultar Antony (2004).
} 
religiosos e de uma produção artesanal de imagens como a do Menino Jesus Bom Pastor em marfim, que, se na Bahia oitocentista inspirou a obra-prima das religiosas do Recolhimento dos Humildes $^{13}$, com o seu peculiar Senhor Deus Menino, no século XIX, teve o seu correspondente no Peru ${ }^{14}$ no culto ao Menino Jesus de Huanca e no Menino Jesus Inca, representações disseminadas pelos jesuítas nos séculos XVII e XVIII, os quais em Lima receberam características das indumentárias indígenas locais.

Na bacia do Rio da Prata, na América do Sul, a Colônia do Sacramento ${ }^{15}$ - no Uruguai (Província Cisplatina), possessão portuguesa - manteve intenso comércio com os hispânicos, localizados no vice-reinado do Rio da Prata, estabelecido em $1778^{16}$, na margem oposta do rio, que contribuiu para o acúmulo de bens na cidade de Buenos Aires, capital do vice-reino, configurando assim, como em Macau e Manila, as relações intraimperiais entre lusos e castelhanos, e suas experiências comuns na absorção de padrões culturais do Oriente em seus espaços coloniais no Novo Mundo. Esses padrões também estão presentes na arquitetura colonial em igrejas com elementos estéticos orientais, como é o caso da Igreja de Nossa Senhora do Rosário em Embu das Artes, construção jesuítica da primeira metade do século XVIII, em São Paulo - permeada em sua sacristia de uma plástica orientalista e que traz um altar dedicado a São Francisco Xavier, o apóstolo das Índias. Também estão presentes na Igreja de Nossa senhora do Ó em Sabará, Minas Gerais, do mesmo período, caracterizada pelas chinoiseries, e pela Igreja de Nossa Senhora da Glória, no Rio de Janeiro, do mesmo período que, segundo

13 Cf. Lúzio (2011).

14 Cf. Silva (2010).

15 Atualmente cidade turística e importante sítio arquitetônico na história do Uruguai.

16 Cf. Fausto e Devoto (2004). 
Martins (2001, p. 93), "lembra mais um templo indiano do que a arquitetura barroca do Rio de Janeiro colonial", haja vista as conexões com o Oriente evocadas no cotidiano ${ }^{17}$ da capital carioca, o que nos sugere comparações e análises com as igrejas barrocas de vestígios orientais do México.

\section{Produção artesanal e comércio no Império português}

As relações Ocidente e Oriente nas unidades coloniais ibéricas produziram ressonâncias em usos e costumes, com a incorporação de artefatos e ideias oriundos dos espaços coloniais afro-asiáticos visíveis em acervos brasileiros e latino-americanos referentes ao período colonial, com ênfase no século XVIII, o auge das vinculações comerciais, já que no século anterior tais vínculos apenas se desenvolveram e no século XIX enfrentaram o seu declínio em função da falência da Carreira da Índia e do fim do Galeão de Manila, quando da independência do México. Um forte comércio estabelecido com a movimentação das naus da Índia em calafetagens e reabastecimentos nos portos brasileiros foi o fator responsável pela disseminação dos produtos orientais nas principais cidades brasileiras. Por outro lado, de acordo com Ahmad (2002, p. 7) "é correto dizer, de um ponto de vista histórico, que a riqueza roubada da América Latina foi um componente financeiro essencial nos recursos que tornaram possível a colonização europeia da Índia". É nessa polaridade que se situa um elo econômico determinante para o funcionamento do sistema colonial português, uma monarquia pluricontinental que se abastecia com os lucros das redes comerciais inter-

17 Ver Freyre (1981). 
continentais do extenso empreendimento lusitano, e de um modo particular na organização da Companhia de Comércio do Estado da Índia.

O comércio consolidado nas redes dos têxteis indianos, que também atendia os mercados de Angola e Moçambique, a comercialização das especiarias, do tabaco, do açúcar e dos metais preciosos, além do rentável mercado de escravos africanos, e das rotas comerciais do marfim pelo Índico, tracejaram o percurso da economia indo-brasileira, num quadro de evoluções dos fluxos mercantis coloniais ao longo do século XVIII que foram ao encontro das etapas da emancipação da América portuguesa no primeiro quartel do século XIX. O dinamismo de um comércio interasiático possibilitou uma reavaliação da dimensão econômica entre o Brasil e Índia, com participação direta de mercados africanos durante o período de permanência da Coroa portuguesa no Brasil, principal componente da estrutura econômica do Império, em suas conexões políticas entre a metrópole e demais espaços do mosaico marítimo que foi o Império colonial português.

Do volume e diversidade de itens que fluíram nas redes deste comércio, inicialmente no porto da Bahia e do Rio de Janeiro, Lapa apresenta fontes para citar que

As mercadorias orientais que entravam no Brasil, principalmente através do porto do Salvador, apresentavam considerável variedade e atingiam cifras respeitáveis na balança comercial da Colônia, mesmo considerando globalmente o comércio do império português. Assim, é na nau Santo Antônio e Justiça, cuja carga arrolamos que dois anos antes da viagem, nos vai fornecer outro exemplo da variedade e volume de mercadorias desem- 
barcadas na Bahia. Do livro da receita que resultou da dízima recaída sobre as referidas mercadorias foi possível relacionar, entre outras coisas, o seguinte material: figuras de barro; pratos e tigelas esmaltadas; mesas de louça dourada; aparelhos de chá; pratos de guardanapo; aparelhos de café; "covilhetes" de tampa; bules de barro; louça grossa de Macau; carpideiras pequenas de cobre esmaltadas; bengalas sem castão; chávenas com seus pires; frasqueiras; porcelanas diversas; pratos de cozinha; tabuleiros de charão; escrivaninha de louça; "cunhetes"; jarras atabacadas e esmaltadas; "inxoens" atabacados; escrivaninhas de metal esmaltado; cana da Índia com castão de ouro esmaltado; coroas de rezar de "Ambaque"; incenso; pimenta; chá; canela fina; figuras de leões; "bispotes"; cobertas de balagate; lenços de algodão; "gargarazes" finos da Costa; peças de "precalos", cortes de vestia de meias; linhas; chitas; lenços de morim, colchas de cetim bordadas, forradas e franjadas; peças de linha de "Surrate"; peças de linha de Diu; peças de linha coromandéis; chitas de balagate; panos de cafre; chita da Costa; cetim bordado; panos de zuarte; peças de linhas cadeas; folhinhas; ramos de folhinha, chitas de Damão, etc. (LAPA, 2000, p. 272)

O eminente historiador comenta da dificuldade de avaliar o vulto da mercadoria procedente do Oriente que era colocada no Brasil, mas argumenta que o declínio do mercado das especiarias acentuou a aceitação das manufaturas orientais e cita um cronista do século XVIII que relata a penetração dos artigos orientais entrados em Salvador como o principal fator de ativação do seu comércio, processo idêntico "que os navios 
da Índia despejavam nos demais portos brasileiros" (LAPA, 2000, p. 272-273). Os dados adquirem mais sustentação quando revelam

[...] a importação do salitre da Índia, que destinava à fabricação de pólvora na Bahia, pois o salitre das minas do sertão baiano era insuficiente para atender à demanda de pólvora de todo o Estado do Brasil, Angola e São Tomé. (LAPA, 2000, p. 282)

Notório observar que, da lista numerosa dos itens orientais, artigos do comércio árabe, elementos dos mercados africanos, produtos indianos, manufaturas chinesas, e artefatos de outras praças asiáticas, foram englobados por, além de Lapa (2000) e Freyre (1981), outros autores que permaneceram na visão de um Oriente homogêneo, sem as devidas particularidades e peculiaridades relativas a cada diferente contexto e cultura que as produziu, o que incorre na assertiva de Edward Said em apontar a percepção massificante do Ocidente ao generalizar distintas culturas e conceitos num único e restrito patamar de produção, que também implica limitar as discussões sobre identidade e memória dos, assim chamados, orientais.

Das culturas indianas, a diversidade é extensa e revela fusões dos dravídicos, autóctones do sul da Índia, com os indo-arianos do norte do subcontinente, e destes com os muçulmanos, presentes na Índia desde o século $\mathrm{XI}^{18}$, oriundos de regiões a oeste do vale do Indo e da Pérsia, e áreas correspondentes aos atuais Afeganistão, Iêmen e Turquia. Das populações africanas da costa oriental é considerável a presença dos bantos entre o predomínio

18 Cf. Ferro (1996). 
dos swahilis ${ }^{19}$, povos afro-asiáticos de reinos afro-islâmicos localizados desde o norte de Moçambique ao sul do Sudão. O contraste se amplia se inseridos os diversos grupos árabes e os asiáticos do extremo Oriente, como chineses e indonésios. Na mesma esfera, os lusos radicados na Ásia, aculturados e circulantes nas rotas comerciais do Império, na manutenção dos seus cargos e negócios dissipados nas zonas periféricas intracoloniais. ${ }^{20}$

O comércio indo-brasileiro é então, um emaranhado de homens e mercadorias que transitaram nas redes afro-asiáticas interligadas ao Brasil, dispersando costumes e concepções. À medida que circulava, promovia interações que se fragmentaram ao longo dos seus extensos percursos, como é o caso das rotas com a Bahia e o Rio de Janeiro, numa trama de redes que absorveu um orientalismo já não mais do Oriente, mas luso-oriental ${ }^{21}$, com expressões específicas como a arte indo-portuguesa em marfim africano produzida em Goa, as faianças com motivos chineses - para citar algumas das inúmeras influências chinesas na arte colonial brasileira, ou os itens dos mercados árabes, sempre associados aos produtos da Índia.

O comércio indo-brasileiro promoveu a circulação de objetos, conceitos e bens oriundos dos diversos espaços coloniais do Oriente nos principais centros urbanos do Brasil colonial, inserindo uma cultura material afro-asiática e, de certo modo, o próprio Oriente que, num primeiro momento resultou numa concepção orientalista na descrição de um patrimônio brasileiro classificado como luso(-afro)-oriental ${ }^{22}$, condicionando-o a uma

19 Cf. Cabaço (2009, p 28).

20 Cf. Lopes (2006).

21 Cf. Dias (2008).

22 É pertinente observar as distintas variáveis geopolíticas, localizando o continente africano no cerne do debate. 
percepção reducionista, reforçando o orientalismo no discurso imperialista. Claro está que se trata de uma epistemologia eurocêntrica, todavia carente de novas análises e de releituras a partir de outras interpretações, como o criticismo pós-colonial ${ }^{23}$ e o debate dos estudos subalternos da historiografia anglo-indiana. ${ }^{24}$ No contexto hispânico, as rotas comerciais do Pacífico e as relações intraimperiais entre portugueses e castelhanos disseminaram o escoamento de mercadorias e padrões culturais do Oriente com evidências documentais no México, Peru e Argentina sobre os vínculos Ocidente/Oriente que se acomodaram e se recriaram no cotidiano das elites coloniais e das ordens religiosas, fenômeno compreensível até porque estas traziam em sua matriz cultural ibérica um componente oriental que sobreviveu como herança moura dos oito séculos da presença árabe na Península Ibérica, tão determinante quanto o mercantilismo, nas readequações e ressignificações dos orientalismos nos espaços coloniais dos reinos ibéricos.

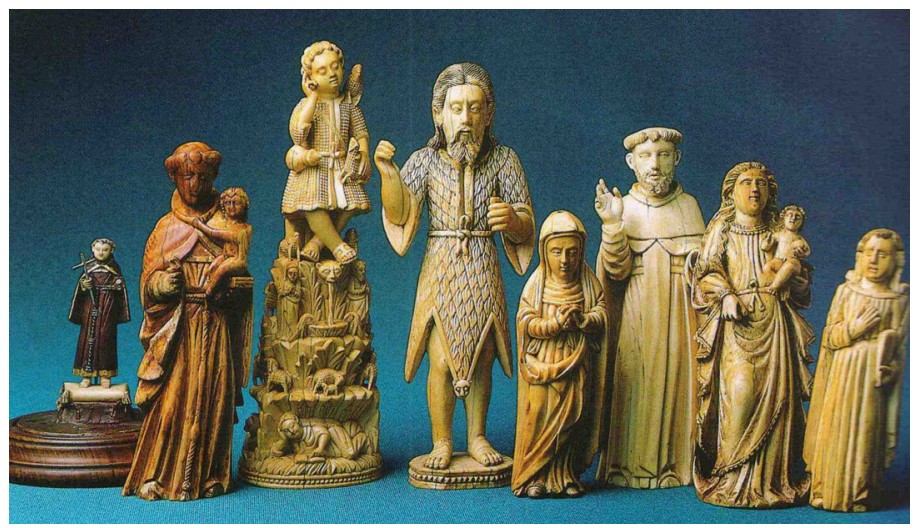

Marfins de Goa - Coleção Mário de Andrade (Col. Artes Visuais, IEB - USP) Fonte: Batista (2004, p. 64).

23 Cf. Antonacci (2009).

24 Cf. Barbosa (s/d). 


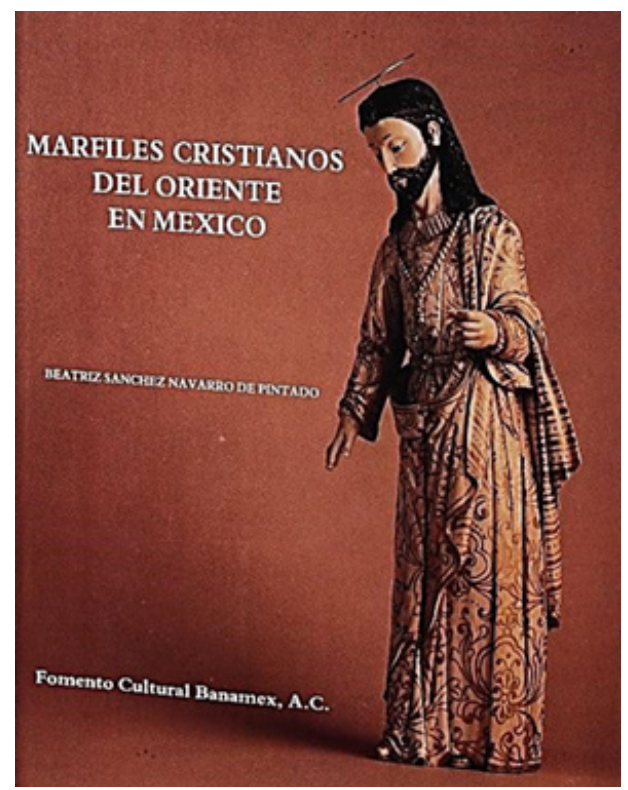

Marfins cristãos do Oriente no México Fonte: Pintado (1985).

\section{Referências}

Ahmad, Aijaz. Linhagens do Presente. São Paulo: Boitempo, 2002.

Antonacci, Maria Antonieta. Colonialidade e decolonialidade de corpos e saberes. Pesquisa financiada pelo $\mathrm{CNPq}$, no triênio 2005/2008. Versão apresentada no I Seminário Internacional Áfricas: historiografia e ensino de história, Salvador e Florianópolis, 2009.

Antony, Philomena Sequeira. The Goa Bahia intra-colonial relations - 1675 / 1825. Tellicherry: Irish, 2004.

BaIley, Gauvin Alexander. Art on the Jesuit missions in Asia and Latin America. 1542-1773. Toronto: University of Toronto Press, 
2001. [Asia en las artes de la America Latina colonial. In: Revelaciones: Las artes en America Latina, 1492 - 1820. Mexico: Fondo de Cultura Económica, s/d.]

Barbosa, Muryatan. A crítica pós-colonial no pensamento indiano contemporâneo. São Paulo: NEACP (Núcleo de Estudos sobre África, Colonialidade e Cultura Política - DH- FFLCH -USP), s/d.

Batista. Marta Rossetti. Coleção Mário de Andrade: Religião e Magia, Música e Dança, Cotidiano. São Paulo: Imprensa Oficial / Edusp, 2004. (Série Uspiana Brasil 500 anos).

Bayón, Damián. Pensar com los ojos: ensayos de arte latino americano. Mexico: Fondo de Cultura Económica, 1993.

CABaço, José L. Moçambique: identidade, colonialismo e libertação. São Paulo: Unesp, 2009.

Dias, Pedro. História da arte portuguesa no mundo (1415-1822): o espaço do Índico. Navarra: Círculo de Leitores, 2008.

Durán, Rosa Dopazo. El Galeón de Manila: los objetos que llegaran de Oriente. México. Castillo, 2005.

Fausto, Boris; Devoto, Fernando J. Brasil e Argentina: um ensaio de história comparada (1850-2002). São Paulo: 34, 2004.

FERro, Marc. História das colonizações: das conquistas às independências - séculos XIII a XX. São Paulo: Cia. das Letras, 1996.

Freyre, Gilberto. Oriente e Ocidente. In: Sobrados e Mucambos. Decadência do Patriarcado Rural e Desenvolvimento do Urbano. 6. ed. Rio de Janeiro: José Olímpio, 1981.

Gruzinski, Serge. O pensamento mestiço. São Paulo: Companhia das Letras, 2001. 
Lapa, José Roberto do Amaral. A Bahia e a Carreira da Índia. Campinas: Hucitec/Unicamp, 2000.

Lopes, Maria de Jesus dos M. O Império Oriental / 1660-1820. In: Nova história da expansão portuguesa. vol. V, tomos 1 e 2. Lisboa: Estampa, 2006.

LúzIo, Jorge. Sagrado Marfim. O Império português na Índia e as relações intracoloniais Goa e Bahia, século XVII: iconografias, interfaces e circulações. 2011. Dissertação (Mestrado em História Social) - PUC/SP, Pontifícia Universidade Católica de São Paulo, São Paulo, 2011.

Martins, Luciana de Lima. O Rio de Janeiro dos viajantes. O olhar britânico (1800-1850). Rio de Janeiro: Zahar, 2001. МемJе, Antonio M. M. América en Filipinas. Madrid: Fundación Editorial Mapfre S. A. 1992.

Pesavento, Fabio. Para além das fronteiras: as redes trans, extra e intraimperiais na segunda metade do século XVIII, Brasil, Portugal e Inglaterra. Tese (Doutorado) - PPGE-UFF, Niterói, 2009.

Pintado, Beatriz Sánchez Navarro de. Marfiles cristianos del Oriente em México. Fomento Cultura Banamex, A.C, México, 1985.

Russel-Wood, A.J.R. A world on the move: The Portuguese in Africa, Asia and America. 1415-1808. Manchester: Carcanet/ The Calouste Gulbenkian Foundation, 1992.

Silva, Edjane G. R. Menino Jesus do Monte: arte e religiosidade na cidade de Santo Amaro da Purificação no século XIX. 2010. 
Dissertação (Mestrado em Artes Visuais) - UFBA, Universidade Federal da Bahia, Salvador, 2010.

Lúzio, Jorge. As redes afro-asiáticas e suas interações culturais com os reinos ibéricos: marfins e mercadorias orientais no Brasil e no México - século XVIII. In: Simas, Monica (Org.). Estudos sobre Macau e outros orientes. São Paulo: Paulistana, 2017. p. 53-67. 


\section{Macau: uma literatura plural? ${ }^{1}$}

\section{Mônica SIMAS $S^{2}$}

\section{Ponto de partida}

Na última década, o interesse sobre lugares de acentuada interseção étnica e cultural parece ter aumentado consideravelmente e aqueles nas fronteiras da presença portuguesa não serão exceção. Considerando que, de meados do século XX, depois da II Grande Guerra em diante, o mundo tem enfrentado várias guerras de fundo étnico como as da Bósnia, do Camboja, do Irã e do Iraque, a Região Administrativa Especial de Macau (RAEM), por ter conseguido defender, até o momento, um convívio seguro aos seus habitantes de tão variadas origens, constitui, sem dú-

\footnotetext{
1 Uma versão em inglês deste texto foi publicada em Asian Diasporic Visual Cultures and Americas, v. 2. Special Issue: Memory and Migration, 2016. ISSN: 2352-3077; E-ISSN: 2352-3085.

2 Professora Associada na Faculdade de Filosofia, Letras e Ciências Humanas da Universidade de São Paulo (USP) e coordenadora do LIA (Laboratório de Interlocuções com a Ásia), onde tem pesquisado as interfaces culturais entre Brasil, Portugal e China. Apoio CNPq; Fapesp-Bolsa Pesquisa no Exterior; monicasimas@usp.br
} 
vida, um lugar especial de reflexão. Se se compararem, ainda, as desastrosas campanhas portuguesas na África e as sofridas guerras pela independência que aqueles países tiveram que enfrentar contra Portugal - Guiné-Bissau, Angola, Moçambique, São Tomé e Príncipe, e Cabo Verde -, o contraste com o processo diplomático de transferência da administração portuguesa de Macau para a República Popular da China (1999) torna a sua história uma exceção absoluta. Também na Ásia, a desocupação de Goa, na década de 1960, e a ocupação de Timor pela Indonésia, logo após a Revolução dos Cravos (1974) em Portugal, mostram que os choques entre grupos e nações estão sempre em curso e que os imperativos de convivência pacífica são uma frágil construção que precisam ser bem preservados.

É Wordie (2013) que, entre seus livros sobre lugares, chama a atenção para o fato de Macau ser descrita comumente e de uma forma simplista como uma sociedade dual, de matriz portuguesa e chinesa, mas que a indicação é imprópria, usada em certos discursos oficiais, fomentando uma mitologia da cidade que não corresponde à sua realidade tão interessante quanto os múltiplos legados que ela contém. Ao seu ver, a realidade histórica é bem mais diversa e particular do que o slogan mais geral de lugar de encontro entre "o Oriente e o Ocidente", sendo formada por várias minorias étnicas que residem na região ou que formaram o sincrético grupo denominado de macaense, hoje, vivendo, por sua vez, diasporicamente espalhado pela América do Norte e do Sul, Canadá e Portugal. O ponto principal do texto de Wordie (2013) é que Macau, como lugar de passagem, foi também o de recepção e residência e, portanto, de contínuas trocas culturais, afetivas e econômicas. Só para dar alguns exemplos, ele mostra como chineses de Burma e da Indonésia vão se estabelecer nos arredores de Mong Há; como os persas fizeram história no ter- 
ritório, sendo os muçulmanos que hoje habitam em Macau bastante discretos comparados aos que residem em outras geografias próximas. Mostra como no Bairro da Horta e Mitra, para os portugueses, ou "Jardim do Pequeno Passarinho", para os chineses, os tailandeses vão desenvolver pequenos negócios desde que o antigo Hotel Estoril, hoje abandonado, começou a buscar massagistas para incrementar o turismo local. Indo além da descrição de grupos nos espaços específicos, Rocha (1998) constata: "Se aceitarmos que Macau é uma sociedade multicultural, então tudo deve fluir dessa característica: as suas leis, as suas instituições, as suas escolas e os seus currículos. A não ser assim, temos uma sociedade multicultural e cidadãos monoculturais" (p. 26). Para o autor não basta justapor monoculturas para se desenvolver uma educação voltada para a multiculturalidade porque esse tipo de organização transporta consigo o gérmen da segregação. Para ele, são necessárias "abertura, troca, interação comunicacional, reciprocidade, solidariedade objetiva" (Rocha, 1998, p. 34). A questão que se quer sublinhar, no espaço dessa breve reflexão, é a de pensar quais implicações as colocações apresentadas trazem à Literatura? É possível se pensar em uma Literatura de Macau multilíngue e multicultural? As análises de repertórios literários da região parecem indicar uma necessária reflexão sobre a própria definição de literatura, pois, até o momento, ela tem sido estudo no âmbito das monoculturas linguísticas localizadas no espaço excêntrico dos cânones produzidos fora do seu próprio território físico. Pensar a Literatura de Macau significa pôr à prova a validade de valores nacionais ou regionalistas e também as alterações por que a própria historiografia literária tem passado desde a década de 1970. 


\section{Molduras teóricas}

Olinto (1996) reforça que, desde que a chamada "Nova História”, na França, postulou rupturas com os modelos tradicionais historiográficos, as historiografias literárias foram deixando de veicular valores essencialistas e passaram, cada vez mais, a integrar a discussão sobre a Literatura com outras das Ciências Sociais. Dos construtivistas mais radicais, como Schmidt ou Rusk, até os cognitivistas, como Maturana, passou a haver uma tendência de teóricos discutirem seus próprios limites, evitando noções de verdade ou aquelas antigas de literariedade. $\mathrm{O}$ sistema literário, nesse contexto, passou a designar condições de produção e de recepção complexas e a ideia de que o texto literário em si e por si pode constituir o objeto de estudo foi desaparecendo.

No campo dos estudos das Literaturas Africanas de Língua Portuguesa, Moraes (2014) identifica que as relações entre literatura e sociologia são antigas, principalmente com a repercussão que os trabalhos de Antonio Candido tiveram no âmbito acadêmico. Ela repara que, no Brasil, tem sido frequente a crítica seguir o modelo teórico proposto por Antonio Candido, com destaque para a sua noção de sistema literário, mas com adaptações, e que vários autores, como o estudado por ela, Ruy Duarte de Carvalho, resistem às noções tal como definidas nessas molduras mais antigas. O que se pode observar é que cada uma dessas literaturas implica questionamentos próprios e tem que ser tratada em suas especificidades.

\section{Crítica e sentido comunitário}

Na apresentação da Antologia de Poetas de Macau (1999), bilíngue em línguas chinesa e portuguesa, Laborinho começa a 
descrever algumas dificuldades de se definir a Literatura de Macau e percorre um artigo de Cheng Wai-Ming em que a Literatura chinesa de Macau entre os anos 1980 e o princípio da década de 1990 é analisada, para mostrar o quão difícil é estabelecer contornos dessa literatura. Laborinho (1999) sublinha que o autor citado considera que a Literatura de Macau é formada por todas as línguas que tematizem o território mesmo que seu autor não tenha ali nascido e crescido, e por quaisquer obras de naturais de Macau. Em contraste, num artigo de outro crítico, Weng Chong, citado no seu mesmo texto, aparece um outro critério, que seria o "estilo literário nacional", tema, assunto e cor local, mas revelando uma grande dificuldade em definir o conceito de "macaense". Parece o restringir ao significado de "filho da terra" (entendido como euroasiático) para, depois, abranger ações dele decorrentes, como culinária e linguagem própria. Portanto, o autor restringe a literatura à temática macaense, apenas incluindo a literatura de expressão portuguesa, sem dúvida, uma forma muito "estrita" de se entender o conjunto dessa literatura.

Retorno ao texto de Cheng (1995), "Literatura chinesa de Macau entre os anos oitenta e os princípios da década de noventa", citado no prefácio de Ana Paula Laborinho, para sublinhar outros aspectos bastante importantes. Logo no início do seu artigo, do mesmo modo que entende que obras editadas fora da região possam ser inseridas na literatura de Macau, como as de Yi Ling ou Wang He, publicadas em Hong Kong e Taiwan, observa que não se deveria concluir que todas as obras que sejam publicadas e editadas na região sejam consideradas "literatura macaense". A observação é importante por dois aspectos: 1) porque, de alguma forma, busca atrelar a noção de literatura a uma noção de construção de sentido comunitário e 2) porque parece alargar a noção de "macaense". A formulação é muito interessante, por- 
que é uma das primeiras análises a fazer uma distinção entre as obras escritas por chineses que nasceram e viveram no território daqueles que ingressaram, da República Popular da China, como estrangeiros. O que parece estar em jogo, nessa formulação, é a importância de se fazer uma ligação entre a produção textual e um projeto cultural que traga significação histórica e, portanto, na abrangência do termo, um sentido "político" a Macau.

Em "A escrita de Macau: uma literatura de circunstâncias ou as circunstâncias de uma literatura", Brookshaw (2010) recorda, antecipando as reflexões apresentadas por Moraes (2014), que essa dificuldade já estava presente nas literaturas africanas das últimas décadas ou na literatura brasileira em determinadas épocas dos séculos XIX e XX. No contexto específico de Macau, e o mesmo servirá para Goa, o professor enfatiza que a noção de literatura deveria abranger, além das categorias tradicionais de ficção, poesia e teatro, a tradição jornalística moderna que remonta ao século XIX. Também defende que, devido ao fato de Macau ser um lugar de "chegadas" e "partidas", muitas vezes, sendo o seu passado evocado através de memórias, os livros publicados fora da região, por autores que emigraram, sejam inseridos no contexto do que se define como literatura de Macau. Ambos, Brookshaw e Laborinho, consideram que o termo writing Macau, paralelo ao writing Hong Kong, proposto por Akbar Abbas (2002), em Culture and the Politics of Disappearance [ou: Hong Kong: Cultural and the Politics of Disappearance], indicando uma formação de corpus literário que não esteja ligada necessariamente à questão de autores e temas, mas sim à maneira pela qual o espaço se inscreve em textos, como espaço cultural, tende a ultrapassar a forma mais tradicional de se pensar o cânone.

Como disse Laborinho, na "Introdução" de Macau na Escrita, escritas de Macau, "ao adotarmos o conceito 'Escrever 
Macau/Writing Macau', é possível delimitar um corpus literário que problematize Macau como um espaço cultural permeado de fricções" (2010, p. 16). O termo teria sido, primeiro, usado para a literatura de Hong Kong, depois, transposto para a literatura de Goa, na dissertação de mestrado de Evandro Luis Von Sydow, $F(r) i c c ̧ \tilde{e} e s$ Goesas: vários mundos numa só vida, defendida na Universidade Federal Fluminense, em 2008, e hoje tem sido utilizado, de forma produtiva, para se pensar também a literatura de Macau. Mas será o espaço, mesmo tomado em sua acepção mais alargada da cultura, necessariamente nuclear ao pensarmos sobre corpus literário?

Parece que a questão "associativa", levantada por Cheng (1995) para se buscar definir essa literatura, não seja menos importante do que a outra. Talvez, ambas somadas, possam alargar horizontes, principalmente com relação ao cânone, mesmo que não consigam traçar contornos do fenômeno literário de Macau de forma exata (ou definitiva).

Por isso, seria, talvez, interessante que se revisse outro texto de Candido (1967/1985), "A literatura na evolução de uma comunidade", que retrata o contexto paulista do Brasil e que toca exatamente nessa questão. O professor já descartava o critério de nascimento, para falar da literatura paulista, em detrimento a um outro, que considerava mais "compreensivo" e que se definia a partir "da participação na vida social e espiritual da cidade de São Paulo" (p. 139). Nessa formulação, literatura já era entendida como "fato eminentemente associativo" (CANDIDO, 1967/1985, p. 139), que não existe sem "um sistema de valores que enforme a sua produção e dê sentido à sua atividade" (p. 140). Parece que essa definição é bem abrangente ao mesmo tempo que evita um relativismo absoluto, desde que o "espaço social", no contexto atual, seja redimensionado e compreendido fora da fixidez do 
local, ou seja, relacionado também aos espaços das migrações ou, ainda, de um modo mais geral, ao mundo das viagens. Dessa forma, a literatura diaspórica, por exemplo, poderia contribuir à diversidade cultural do espaço social do "local de destino" ao mesmo tempo participar da "vida espiritual" dos valores do "local de origem", ou seja, nem sempre o local da vida social é o mesmo daquele dos valores mentais e culturais de uma determinada formação.

Também a meu ver, no seu artigo, Cheng (1995) busca exatamente definir a literatura de Macau a partir desse sentido mais "compreensivo", buscando caracterizar justamente esse "sistema de valores" que enformam a produção escrita de língua chinesa bem como o seu vigor, já que, segundo as suas contas, no simples período citado de uma década e meia, teriam sido lançadas, em Macau, pelo menos 23 coletâneas de poesia (de língua chinesa). Esse é um dos artigos, de maior fôlego, sobre a literatura chinesa de Macau e, devido à sua restrita circulação, é pertinente acompanhar as principais informações a respeito dessa literatura, pouco conhecida entre os que não têm domínio da língua chinesa e que serão, certamente, de interesse a algumas mediações com as literaturas de língua portuguesa e de língua inglesa da região.

\section{Literatura de língua chinesa de Macau}

O professor faz, no seu texto, um pequeno histórico de como a literatura chinesa desenvolveu-se em Macau, mostrando a importância de algumas instituições e associações que apareceram no período, como a criação da Universidade da Ásia Oriental, primeira universidade moderna, na história de Macau e também a organização da "Associação da Literatura Chinesa" 
ligada à mesma universidade (CHENG, 1995). Além disso, o "Diário de Macau" (Macao Daily Newes) teria criado uma página literária, nos anos de 1980, reforçando o interesse por obras de ficção e poesia. O mesmo jornal, de acordo com o autor, promoveu um simpósio, em 1984, com a presença de escritores de Hong Kong e de Macau. Um ano depois, a Associação da Literatura Chinesa da Universidade da Ásia teria organizado e publicado a primeira coleção de obras literárias, em cinco volumes. Até então não se encontrava, em Macau, nenhuma instituição destinada a editar livros literários chineses. Em 1986, foram promovidos encontros mensais sobre a nova poesia e o "Prêmio Júnior da Literatura", patrocinado pela referida Associação, juntamente com o jornal Va Kio, o Centro Pastoral da Juventude Católica de Macau e a Federação dos Estudantes de Macau. Em 1987, foi criada a Associação dos Escritores de Macau (Pen of Macau). Em maio de 1989, fundou-se a Associação Poemas de Maio de Macau, reunindo cerca de 30 membros da mais antiga e média geração. Em 1990, foi criada a Associação de Arte Poética de Macau, destinada exclusivamente à composição dos poemas antigos. A referida Associação tem um periódico regular, desde então, a "Poesia Macaense". Já na década seguinte, 1992, foi fundada a Associação Técnica de Composição Literária de Macau, formada por um grupo acadêmico e erudito macaense que se ocupava do ensino e estudo da composição literária. No período de transição, a literatura chinesa teria passado, portanto, por uma transformação absoluta, da insuficiência de páginas destinadas à publicação de colunas literárias em jornais locais ao crescimento constante de publicações com o reconhecimento de várias regiões vizinhas, como Hong Kong e Guangzhou.

Em relação às formas estéticas da poesia contemporânea de Macau, Cheng (1995) mostra que a forma tradicional dos "ci" 
(um padrão de versos antigos) ocupa um lugar de destaque entre a comunidade, aparecendo simultaneamente em formas antigas e renovadas. Haverá, entre os poetas de versos modernos, duas facetas, uma de uma poesia suave, terna, romântica, que descreve sentimentos afetuosos ligados à natureza, e, outra, de uma poesia com inspiração mais realista, política e histórica, entre as quais se destaca a poetisa Yi Ling. Existe também uma escola que se caracteriza pela poesia "nebulosa" do interior da China, mais sugestiva e simbólica e, numa outra mão, a tendência poética modernista de expressão chinesa de Hong Kong e do ultramar mais voltada para o cotidiano e os movimentos de vanguarda. Além disso, os temas foram amplificados na literatura atual, bem como o rompimento de tabus, com o predomínio de "uma reavaliação de fundo sobre a racionalidade e valor de todas as coisas do tempo e espaço onde nos inserimos" (Cheng, 1995, p. 518).

Se tomarmos a Antologia de Poetas de Macau, organizada por Arrimar e Yao (1999, p. 226), citada anteriormente, e que reuniu 20 poetas de cada língua, podem-se observar algumas das diferentes formas poéticas referidas por Cheng na teia que vai desde imagens sutis de aspectos da natureza, mas já com algum estranhamento, como em "Cidadezinha", de Wang Hao Han, até a denúncia explícita dos problemas da cidade, como em "Paisagem de Macau", de Gao Ge, ou "Incinerador", de Wu Gao Chang:

\section{Gidadezinha}

Os raios solares decorando a cidadezinha no Outono

Mesmo as ruelas partilham da sombra do sol

A trepadeira verde sobe janelas desbotadas

e as aldrabas da porta ferrugenta fecham o silêncio. 
$[\ldots]$

Em todos as ruas apenas olhos estranhos

Eu deixo repousar a saudade nas acácias

e aguardo secretamente que Maio floresça rubro

[...] (p. 194)

\section{Paisagem de Macau}

$[\ldots]$

O Deus que protege a Praça do Cavalo de Cobre saiu do memorial ainda numa postura de dom Quixote

e os alcoviteiros adaptaram histórias eróticas com as lendas do herói.

São histórias que se repetem todas as noites

porque nas gaiolas de luxo vive-se um ambiente sensual em que os homens sobrevivem com uma sensação amorosa

Mas a questão é como manter a eterna erecção

e como fortalecer o regime representativo com o bálsamo mágico da Índia

"O jogo moderado dá prazer" é justificativa do público para se divertir

Os "Come-moedas" funcionam para criar efeitos publicitários Desde os assaltos dos piratas até aos desafios contra o rei do casino

tudo é uma combinação da civilização ocidental e da sabedoria oriental.

[...] (p. 143-144) 


\section{Incinerador}

Quando chegamos frente ao sol

o fumo preto da fábrica volta a rir cinicamente

$[\ldots]$

Trabalhar um dia todo para trocar por uma noite que se consome

no êxtase das chamas de néon

E depois refrescamo-nos com uma coca-cola gelada

As correntes de lata de estanho incorporam-se delicadamente na maré consumista

$[\ldots]($ p. 226)

Que a poesia chinesa se ponha de forma antagônica aos processos de um materialismo exacerbado que tomou conta de Macau não deve causar espanto, pois é próprio da poesia resistir aos ritos do mercado, ou tentar sobreviver apesar deles, mas evocar um certo despertencimento depois da transferência do território é quase uma subversão. Seguindo os passos da leitura de Yao (2010), no seu artigo "Em busca do habitável a partir da Antologia de Poesia Contemporânea de Macau", de Li Guanding $\left(2007^{3}\right)$, na poesia de Yi Ling, cidadã residente em Macau e portadora do bilhete de identidade de Hong Kong, há um questionamento acerca da própria possibilidade de Macau ser um lugar ao qual pode se pertencer. Segundo Yao,

3 Guanding. Li. Antologia de Poesia Contemporânea de Macau. Macau: Fundação de Macau, 2007. Citado em Yao (2010). Em busca do habitável a partir da Antologia de Poesia Contemporânea de Macau ... em Laborinho ... e Pachoco, Macau na escrita, escritas de Macau ... 
Trata-se de uma das vozes mais corajosas, moldando o seu discurso poético com uma profunda consciência de intervenção social. Como cidadã residente em Macau e portadora de bilhete de identidade de Hong Kong, Yi Ling já expressou no livro Ilha Móvel, editado em 1990, a dificuldade de identificar-se com uma terra dentro da própria terra. Nesta perplexidade, a relação entre o Eu e o país é mediada mais por aqueles valores universais do que pela cegueira do patriotismo. Como chinesa, não lhe custa identificar-se com a cultura chinesa mas ela não consegue identificar-se com um regime ainda menos democrático, o que lhe atribui uma postura dissidente que subsiste sob muita pressão numa sociedade conservadora como Macau. (2010, p. 55)

Percebes o que é o destino de repouso?

É onde a vida começa e acaba

É onde se nutrem o pensamento e o sentimento

É onde se guardam o desejo e a gratidão

É um lugar inexistente no mapa frio

mas sim é guardado quente no fundo do teu coração

(Li Guanding, 2007, p. 524. Citado em YaO, 2010, p. 55-56)

A expressão desse incômodo, no entanto, é muito incomum. Yao considera que, ao contrário, muito comum, é encontrar, na poesia chinesa, antes ainda da transferência ou logo nos anos seguintes à transferência, a imagem de Macau como "um filho humilhado" por ter sido ocupada pelos portugueses. Os chineses aguardaram com confiança o futuro da região, no entanto a série de escândalos que surgiu com relação ao governo da RAEM 
deixou a população bastante decepcionada. Apesar disso, o constante é não intervir, como aparece no poema de Lu Aolei, traduzido por Yao da seguinte forma:

O que pensa da situação actual, por favor?

Não tenho nada a dizer.

Qual é sua opinião sobre a prevenção da epidemia, por favor? Óptimo! Não aponte a câmara para mim.

Onde é que vamos, por favor?

Silêncio! Distribua as cartas!

Como é Macau de agora?

Chegue ao balcão 2 para apostar.

[...] (Li Guanding, 2007, p. 245. Citado em YaO, 2010, p. 56)

Seja nas imagens de um exílio na terra própria, na dificuldade de se enraizar, na monotonia repetida, ou seja, naquelas de vazio, de tédio e de solidão, que se sucedem nos trechos selecionados por Yao (2010) para comentar a Antologia da Poesia Contemporânea de Macau, o que vem à tona é um desconcerto muito grande, jogando o leitor contra os slogans que circulam nos discursos oficiais/ turísticos da cidade.

\section{Novas apostas: a poesia de língua inglesa}

O próprio título da apresentação de Yao (2010), no Congresso "Macau na escrita, escritas de Macau" - "Em busca do habitável" - parece reforçar a ideia de uma necessidade de os poetas de Macau pensarem o espaço vivido no cotidiano da própria cidade. Nesse sentido, talvez, o espaço linguístico da "língua comum" das vivências urbanas - o de língua inglesa, tenha crescido bastante em seus testemunhos. 
Devido às dificuldades que os chineses têm para aprender o português e vice-versa, que os portugueses têm para aprender o chinês, é comum, entre as diversas comunidades presentes hoje em Macau, que a comunicação se dê em inglês, como segunda língua, uma língua estrangeira que as diferentes comunidades vão tentando aprender. Hoje, na região, devido às oportunidades de emprego na área de serviços exigirem o domínio da língua inglesa, especialmente os cassinos e restaurantes, o ensino dessa língua vem sendo bastante reforçado. Também as migrações de mão de obra especializada do sudeste asiático e da Austrália para Macau estão formando uma nova comunidade de língua inglesa com estadia mais duradoura na região.

Num gesto bastante "novo", em 2008, Kelen e Vong publicaram uma antologia de poesia contemporânea de Macau, a primeira tentativa de reunir a poesia de Macau para um público leitor de língua inglesa, como afirma o editor na introdução do livro. Mais da metade dos poemas da antologia foram traduzidos do chinês, perto de um quarto do português e o resto foi escrito originalmente em inglês. Entre os mais de 100 poetas que participam da antologia, 33 escreveram originalmente em inglês. Isso permitiu a Kit Kellen afirmar que: "o número de poemas não traduzidos atesta a criação local de uma nova literatura inglesa" (2008, p. 18). ${ }^{4}$ Literatura inglesa ou literatura inglesa de Macau querendo dizer literatura de Macau em língua inglesa? Observo também que a maioria dos poemas chineses e portugueses dessa antologia em língua inglesa foram recolhidos das antologias anteriormente referidas (tanto as chinesas quanto a de Yao) e que o critério de seleção foi, simplesmente, poesia "de e sobre

4 Tradução livre de "[the number of untranslated poems] attests the local creation of a new English literature". 
Macau", no entanto acabou pondo em circulação numa obra conjunta onde os autores de línguas diferentes poderiam, a partir daí, conhecer a escrita uns dos outros. O trabalho foi "em processo" e durou três anos e incluiu em torno de 15 tradutores. A edição foi limitada e a sua circulação ainda é bastante restrita.

Muito elucidativa também são as palavras de Kellen (2008) ao explicar o objetivo principal da antologia: "nosso propósito, neste caso, foi criar uma antologia inclusiva com um tom democrático; isto é, representar tantas e tão variadas vozes poéticas quanto possível" (p. 18). ${ }^{5}$ Se, por um lado, o critério de seleção dessa antologia é altamente contestável, pois tanto para Yao quanto para Cheng, este "sobre Macau" pode "não significar nada" em termos de conceituação para a definição de "literatura de Macau", por não ter nenhum vínculo associativo, por outro, sem dúvida, é a mais abrangente e completa antologia de poesia contemporânea de Macau feita nos últimos tempos. Também, em relação ao termo "macaense", opta por uma postura prudente em que prefere substituir estrategicamente o termo por "de Macau". Além disso, a sua antologia dá visibilidade às comunidades minoritárias de língua inglesa ao mesmo tempo que, como língua franca utilizada em Macau, vai ao encontro de um público mais abrangente.

Kelen, australiano, professor, na Universidade de Macau, de redação criativa, poeta e editor, parece ver o espaço citadino de Macau como esse lugar de muitas possibilidades e também de determinações. Para sobreviver à intensa pluralidade de signos

5 Tradução livre de "our aim in this case has been to create an inclusive anthology with a democratic tone; that is, to represent as many and as varied poetic voices as pratical" (p. 18). 
da cidade é necessário fazer escolhas o tempo todo. Por sobre o lance dos dados mallarmeniano, no seu "Poem for Macao", faz rolar os "dados dos cassinos":

\section{Poem for Macao}

I roll the dice

and the numbers

fall out

they spread on the table

I think I hear

a sigh of relief

now luck is everywhere

for good or for ill

everyone has it

the dice are blank

as if to say

'now it's your turn -

Choose!' (Kelen, 2008, p. 123)

Próprio dos espaços urbanos hipersemiotizados, o prazer estético de redescobrir e regenerar cada vez (que os dados são lançados) a força inventiva que eles podem transmitir, existe na atenção do olhar dessa poesia, mas seria só nela? Buscar um fio de sentido às peculiaridades dessa cultura multicultural

6 Versão livre: "Poema para Macau"/ eu jogo os dados/ e os números/caem/ espalham-se na mesa/ Eu penso que escuto/ um sinal de alívio/ agora a sorte está em todo lugar/ para o bem e para o mal/ todos a têm/ os dados estão brancos/ como se dissessem/ 'agora é a sua vez - escolha'. 
parece ser um desafio aos poetas de Macau de todas as línguas. Além disso, cada vez mais, como editor, o seu trabalho vem expandindo fronteiras e, como poeta, fazendo interfaces com outras artes.

Na fascinação pela representação do espaço, em seus cursos e publicação de poesia, Kellen (2009), em seu mais novo estudo sobre a poesia da RAE de Macau, City of Poets, exploring Macao Poetry today, pergunta se ela será uma mera construção fantasista tal como entendida pela crítica em relação ao exótico, de acordo com o orientalismo concebido por Edward Saïd. Na verdade, aproveita para reconhecer a tensão que Saïd identifica na visão orientalista, entre a tendência universalizante e a de um engajamento com o "aqui" e "agora" de forma que seja produtiva para a criação poética. Aproveita a larga tradição anglo-saxã da poesia moderna, motivando os seus alunos a situarem o conhecimento particular, a isolarem elementos, tal como o define, por exemplo, a sugestão de Raymond Williams, de uma "radical particularidade", na qual, mesmo tendo sido isolados, mostrarem-se conectados a características dominantes. Como um lugar comum em meio a outras megacidades do sul da China ou do leste da Ásia, para Kellen, teoricamente, pontos anunciados por Benjamin, Bradiliard, Certeau, Zukin, Augé seriam contíguos à vontade de resistência à lógica mundial que aparece na poesia de língua inglesa mais recente. No seu estudo, tenta fazer um paralelo entre o lugar do poeta e o da cidade, na República de Platão, e o dos poetas dos tempos atuais e as novas desorientações urbanas.

Buscar a legibilidade do espaço, portanto, caracterizado dentro de uma dinâmica de desenvolvimento que mudou radicalmente o seu ambiente, as suas acessibilidades e as suas representações culturais, parece constituir um terreno comum 
às poesias de língua chinesa, de língua inglesa e, como se pode ver logo adiante, de língua portuguesa.

\section{Macau: cultura portuguesa em novos rumos}

Como já foi referido, depois da década de 1970, se dá, em Macau, uma ascensão expressiva dos valores culturais chineses, no que acarretou o incremento de publicações. Cabral e Lourenço (1993) apontam para uma total reformulação da identificação do macaense ${ }^{7}$ em relação aos tradicionais vetores que definiam o seu projeto étnico, ou seja, a associação com a língua portuguesa, a miscigenação entre sangue europeu e asiático, e a identificação com o cristianismo. Em finais da década de 1960, com a introdução da televisão em cantonês, afirmou-se progressivamente a mudança das formas de socialização da comunidade, privilegiando-se o cantonês como língua de interação. As antigas estratégias associadas ao contexto matrimonial também foram deixando de funcionar por conta da tendência que se manifestou, durante os anos 1980, de os casamentos se fazerem fora da comunidade lusófona. Os chineses assumiram, de forma crescente, os direitos de cidadania, em um movimento que convergiu com o da classe média que participava do contexto da lusofonia. De acordo com

\footnotetext{
7 Genericamente, termo usado para designar os euro-asiáticos de cultura portuguesa, numa formulação que, claramente, distingue e separa as famílias chineses que também residem no território numa longa duração, mas que, aos olhos da sociedade euro-asiática, eram inscritos simplesmente na "cultura chinesa". Nunca houve a preocupação de se fazer uma caracterização dos "chineses de Macau" ou "chineses macaenses". O primeiro e único trabalho científico que se ocupou da comunidade chinesa de Macau é o de Santos e Gomes (1998) e teve a sua circulação impedida ou dificultada, em Macau, nos anos de transição.
} 
os autores, os macaenses deixaram de se apresentar como promotores do projeto privilegiado dos portugueses (colonial), ${ }^{8}$ passando a legitimar a sua presença em virtude da contribuição histórica que Macau trouxe para a própria China. A ação discursiva dos macaenses passou a recair, fundamentalmente, sobre a interculturalidade no sentido de se caracterizar uma condição cultural "especial" do território.

Destituídos da possibilidade de manifestar a sua vontade política, através de uma representação oficial no contexto das negociações que determinaram a transferência da soberania, ficaram, portanto, com a pertença cultural dessa condição que se formulou como "condição especial". As transformações do projeto étnico macaense, mencionadas por Cabral e Lourenço (1993), surgiram nesse fluxo de articulação das determinações políticas com a elaboração dos significados da sua formação e presença na região. Juntamente com a transformação do projeto étnico macaense que é analisada por Cabral e Lourenço, ocorreu uma alteração dos modos de recepção da produção literária dos escritores macaenses enquadrados na lusofonia.

8 É possível considerar que, apesar de Macau não ter sido propriamente uma "colônia", até porque o seu estatuto político só foi clarificado, no período de transição, depois que Macau foi inserido no contexto dos "tratados desiguais" e, ainda, principalmente, depois que a tese histórica de Fok Kai Cheong, acerca das bases da instalação dos portugueses na região, começou a circular, existiu, em Macau, uma administração colonial, uma educação em acordo com as sociedades coloniais e formas de socialização afins às coloniais e, portanto, a região foi eivada de discursos no âmbito dos colonialismos, de forma muito marcada, no período de 1880 até os anos de 1970 em que o capital cultural chinês começou a preponderar. O que quero afirmar é que associar Macau à crítica pós-colonial é perfeitamente plausível. Como afirmou Ana Mafalda Leite, no seu Literaturas Africanas e Formulações Pós-Coloniais (2003), a crítica pós-colonial não pode ser atrelada de forma restrita nem aos países recém independentes nem a um sentido cronológico. $\mathrm{O}$ termo diz respeito à crítica que analisa, frustra e desconstrói as estratégias discursivas formadas no âmbito dos impérios. 
A recepção de textos dos mais conhecidos representantes da comunidade macaense, de matriz portuguesa, José dos Santos Ferreira, Luís Gonzaga Gomes, Deolinda da Conceição e Henrique de Senna Fernandes passou a ser atualizada em função de uma acumulação de significados que correspondem à tradição do passado de uma (grifo meu) dentre as várias etnias que compõem o território, deslocando uma perspectiva que abrangia esses textos como a representação de uma força cultural dominante (colonial) para uma de diversidade cultural.

A memória coletiva dos macaenses legitima, sem dúvida, uma identidade cultural bastante particularizada de Macau, evocando uma cultura crioula que pode ser identificada na língua própria de Macau (patoá de Macau), e que, hoje, apesar de ter perdido a sua função comunicativa, foi reavivada, recentemente, com a criação do grupo Papiaçam di Macau, dirigido por Miguel de Senna Fernandes. Com certeza, é na culinária que o padrão dessa cultura mestiça é mais vivo e forte.

No período de transição, de 12 anos, a alteração do modo de se compreender a presença cultural portuguesa foi seguindo as transformações das infra-estruturas pelas quais a região passou e que serão descritas no próximo capítulo. O que interessa a este trabalho é que esse mar de empreendimentos e acontecimentos que transcorreram em Macau foi responsável pelo retorno ao território de macaenses que viviam diasporicamente e antigos residentes portugueses que haviam partido em decorrência da situação do Pós-Guerra, acionando antigas solidariedades do eixo familiar e/ou do círculo de amizades. Foi também responsável pela transferência de vários portugueses, tanto de Lisboa quanto dos países africanos, para Macau - seja por se enquadrarem nos quadros funcionais das instituições públicas, seja por buscarem melhores oportunidades de trabalho na iniciativa privada. 
Das rotas africanas surgiram, na poesia, modulações de vozes e ritmos que procuram marcar a fusão de tempos ou de fragmentos espaciais, como os que aparecem nas poesias de Jorge Arrimar e de João Rui Azeredo, ou ainda, de Alberto Estima de Oliveira. Nota-se, nesses escritores, no período de transição, a presença de uma preocupação comum em ancorar sentidos do tempo histórico em seus textos, por conta das transformações culturais radicais pelas quais passou a região. Portugueses que cruzaram a RAE de Macau, como José Augusto Seabra, em seu Poemas em nome de Deus (1990), ou José Jorge Letria, em seu Oriente da mágoa (1992), acabam por ativar, inclusive, os sentidos míticos da possível presença de Camões na região e também da história de Portugal. Este último livro, um longo poema narrativo, retoma, por exemplo, o exílio de Camões, dentro de uma noção decadentista que se formou, na Europa, com relação ao oriente, nos séculos XVIII e XIX, fixando-o dentro da visão romântica. De uma forma bem mais complexa, estará Macau representada, em meio a outras localidades, no oriente de Até ao longínquo China navegou ..., de Antônio Manuel do Couto Viana, publicado pelo Instituto Cultura de Macau, em 1991. Todas essas obras precisariam ser estudadas, de forma cuidadosa e atenta, para que se pudesse fazer uma análise mais rigorosa da significação de Macau.

Na RAE de Macau, enquanto a fugacidade e o provisório eram conceitos sinalizadores da ruptura eminente, que emergiam em textos diversos, uma demanda de rememorações procurava resistir à voracidade do tempo. Na poesia, é possível verificar que os poetas produziram um inventário de referências do espaço urbano, tornando-se cúmplices da(s) cultura(s) outra(s), mas, de algum modo, não deixam de situar Macau como um signo que interroga as suas próprias qualidades. 
Em Margens do Destino. Macau e a literatura em língua portuguesa (SIMAS, 2007a), foi feita a análise de várias obras entre elas Chü Kong, de Maria do Rosário Almeida (1987), também da obra de João Rui de Azeredo (1992), de Fernanda Dias (2002) e, ainda, da prosa do mesmo período, para o qual se remete o leitor. Desta última autora seria interessante que se desse a conhecer este primeiro poema do livro Chá verde:

\section{definição}

chá: esse outro meu coração verde

que fora do meu peito pulsa.

ritual de silêncio, amargo e quente,

que te dou a beber em cada taça

(DIAS, 2002, p. 13)

O poema abriga, de cara, uma alta interação com esse "outro" cultural, o que vai se revelar também no fato de traduzir e recontar poesia e estórias das comunidades chinesas de Macau. Fez versões para a poesia de Wong Io Fong, conhecido por Gao Ge e para a poesia de Shu Wang, além de, em 2011, num gesto admirável, ter publicado uma versão poética do Yi Jing, ${ }^{9}$ o clássico livro das mutações, que está tanto na base do pensamento taoísta quanto na do confucionismo, sendo considerada, portanto, uma das obras mais importantes do enraizamento cultural.

Própria das transculturalidades é a convivência da habitação de mais de um código cultural na ação ético-social, nos modos de se falar, ou seja, nos usos da linguagem.

9 Escrevi um ensaio sobre essa obra de Fernanda Dias, a ser publicado na Revista de Cultura do ICM. 


\section{Conclusão}

Do ponto de vista da multiculturalidade, a literatura de Macau apresenta-se bastante rica, com um vasto repertório e com instigantes perspectivas para a crítica. Ao se questionar sobre a possibilidade de essa literatura ser percebida em sua forma plural, acredita-se que ela pode, ainda, revelar uma contribuição ímpar às próprias definições do fenômeno literário, constituindo uma elaboração em processo daqueles limites axiais produzido mais em função da alteridade do que de definições de identidades.

\section{Referências}

Abbas, Ackbar. Hong Kong: Gultural and the Politics of Disappearance. 3. ed. Minnesota: University of Minnesota Press, 2002.

AlmeidA, Maria do Rosário. Chü Kong. Macau: Instituto Cultural de Macau, 1987.

ARrimar, Jorge. Secretos sinais. Macau: Instituto Cultural de Macau, 1992.

Arrimar, Jorge; YaO, Jingming (Sel. e Org.). Antologia de Poetas de Macau. Macau: Instituto Camões, Instituto Cultural de Macau, Instituto Português do Oriente, 1999.

Augé, Marc. Não lugares. Introdução a uma antropologia da supermodernidade. Campinas: Papirus, 1994.

Azeredo, João Rui. Poemacau. Macau: Livros do Oriente, 1992. Brookshaw, David. A escrita em Macau: uma literatura de circunstâncias ou as circunstâncias de uma literatura. In: 
Laborinho, Ana Paula; Pinto, Marta Pacheco (Org.). Macau na escrita, escritas de Macau. Vila Nova de Famalicão: Húmus, 2010. p. 19-30.

Cabral, João de Pina; Lourenço, Nelson. Em terra de tufões. Dinâmica da etnicidade macaense. Macau: Instituto Cultural de Macau, 1993.

Candido, Antonio. O escritor e o público. In: Candido, Antonio. Literatura e Sociedade: estudos de teoria e história literária. 7. ed. São Paulo: Nacional, 1985. p. 73-88.

Candido, Antonio. A literatura na evolução da comunidade. In: Candido, Antonio. Literatura e Sociedade: estudos de teoria e história literária. 7. ed. São Paulo: Nacional, 1985. p. 139-167. 1a edição de 1967.

Cheng, Wai-Ming. Literatura Chinesa de Macau entre os anos oitenta e os princípios da década de noventa. Revista Administração, v. 8, n. 29, p. 501-523, 1995.

Couto Viana, António Manuel. Até o longínquo China navegou. Macau: Instituto Cultural de Macau, 1991.

Dias, Fernanda. Chá Verde. Macau: Círculos de amigos da cultura de Macau, 2002.

Kelen, Christopher. City of Poets, exploring Macao Poetry today. Macau: ASM, 2009.

Kelen, Christopher; Vong, Agnes (Org.). I roll the dice. Macau: Association of Stories in Macau, 2008.

Laborinho, Ana Paula. Introdução. In: Laborinho, Ana Paula; PINTO, Marta Pacheco (Org.). Macau na escrita, escritas de Macau. 
Vila Nova de Famalicão: Húmus, 2010. p. 9-16.

Laborinho, Ana Paula. Apresentação. In: Arrimar, Jorge; YaO, Jingming (Sel. e Org.). Antologia de Poetas de Macau. Macau: Instituto Camões, Instituto Cultural de Macau, Instituto Português do Oriente, 1999.

LeIte, Ana Mafalda. Literaturas Africanas e Formulações Pós-Coloniais. Lisboa: Colibri, 2003.

Letria, José Jorge. Oriente da mágoa. Macau: Instituto Português do Oriente, 1992.

Moraes, Anita. Espaço e representação em Ruy Duarte de Carvalho. In: Alves, Ida; Lemos, Masé; Negreiros, Carmem (Org.). Estudos de paisagem: literatura, viagem e turismo cultural. Rio de Janeiro: Oficina Raquel, 2014.

Olinto, Heidrun Krieger. Histórias da Literatura: as novas teorias alemãs. São Paulo: Ática, 1996.

Rocha, Rui. Macau, Sociedade Multicultural? Revista da Cultura, Macau, II Série, n. 78, p. 26-35, out. 1998.

Santos, Boaventura de Sousa; Gomes, Conceição. Macau: o pequeníssimo dragão. Lisboa: Edições Afrontamento, 1998.

Seabra, José Augusto. Poemas em nome de Deus. Macau: Instituto Cultural de Macau, 1990.

Simas, Monica. Margens do Destino: Macau na literatura em língua portuguesa. São Caetano: Yendis, 2007a.

Simas, Monica. De Portugal à África a Macau: exclusões, inclusões. Via Atlântica, São Paulo, n. 12, p. 67-77, 2007 b. 
Von Sydow, Evandro Luis. F(r)icções Goesas: vários mundos numa só vida. Tese (Doutorado em Letras) - Universidade Federal Fluminense, Niterói, RJ, 2008.

Wordie, Jason. Macao. People and places, past and presente. Hong Kong: Angsana, 2013.

YAO, Jingming. Em busca do habitável a partir da Antologia de Poesia Contemporânea de Macau. In: Laborinho, Ana Paula; PInTo, Marta Pacheco (Org.). Macau na escrita, escritas de Macau. Vila Nova de Famalicão: Húmus, 2010. p. 49-61.

Simas, Monica. Macau: uma literatura plural? In: Simas, Monica (Org.). Estudos sobre Macau e outros orientes. São Paulo: Paulistana, 2017. p. 68-94. 


\section{Oriental(ized) Portuguese-Anglophone Literature, Culture, and Colonial Stereotypes}

\section{David BROOKSHAW}

The root of stereotypes is prejudice, and the root of prejudice, according to Gordon Allport (1954), is the need felt by one human group to define itself against another or others. During the period of European imperialism, colonial rule was upheld and underpinned by prejudice, which in turned was justified by theological and, in the course of time, pseudo-scientific theory. African slavery in the New World was justified by the notion that the forced migration of slaves brought them into Christendom, and therefore freed their souls to enjoy the afterlife, while later, their continued enslavement and/or abandonment at the bottom of the social pyramid could be explained by their inherent backwardness, now bolstered by Social-Darwinist theories. At the same time, all manner of specific stereotypes emerged to allow the dominant group to assuage its conscience by 're-fencing' its

1 University of Bristol; D.R.Brookshaw@bristol.ac.uk 
prejudice, to use another of Allport's term (1954, p. 23). The dangers (and delights of - or right to) consort with the female slave among slaveowners and their offspring, brought with it the idea that the slave woman was naturally lustful. In Brazil, of course, this witnessed the birth of all the mythology surrounding the 'mulata', elevating the female born within slavery (or indeed out of it) to a female fantasy figure for the dominant white male. Yet during the nineteenth century, when slavery began to be questioned, and an abolition campaign mounted in literature, a new stereotype emerged: that of the suffering slave woman, as depicted in fiction, drama and poetry. This detail will become relevant later in this paper, when we discuss the subject of the Eurasian female in fiction about Macau or the Macanese.

But prejudice and stereotypes were not just the product of the top-down culture of social control within colonial society, the maintenance of what in effect amounted to a caste system. Prejudice emerged out of colonial rivalries. A number of colonial rivals were, of course, European neighbours, with a history of cross-border suspicion and hostility (England/France, Portugal/ Spain), but the biggest rift occurred between Northern and Southern Europe, based as it was on religious difference. The Black Legend, which portrayed the Spanish as fanatical, cruel and bigoted, may have been born elsewhere, but it was widely used in anti-Spanish propaganda in England, as Tudor and then Stuart England sought to carve out its own imperial space in the New World. This prejudice against a supposedly prejudiced Spain was to outlive the century or so of Spanish colonial supremacy, to later feed the nineteenth-century 'romantic' view of Spain projected by writers such as Washington Irving and Prosper Merimée: a Spain of Moorish castles, gispsies, and flamenco, in short, an orientalized Spain, still fanatical, but now 
're-fenced' as exotic other. In other words, behind every negative stereotype, there was the potential for a supposedly positive, attractive, and interesting alternative. It is important to bear in mind this violent, dangerous, but exotically seductive depiction when reading Charles A. Gunnison's short story, 'In Macao'.

\section{The Oriental(ized) Portuguese male}

Gunnison (1861-97), who was the secretary of the Commercial Publishing Company in San Francisco, published 'In Macao' in $1892^{2}$. Set in Macau, as the title indicates, it mingles elements of romanticism with gothic horror, as two critics have pointed out (PugA, 2011; SHAw, 2011). The narrator tells the story of his uncle, Robert Adams. The tale opens with the narrator sitting near the Camoens Grotto, when a priest sits down next to him and engages him in conversation, and begins to tell him about Goa. Suddenly, the narrator's uncle, Robert, appears from under a great banyan tree, the priest jumps up and attacks him with a knife, but is gunned down. The bulk of the story is then a long flashback to explain this action, leading us eventually back to the opening scene of the tale.

Robert Adams, the narrator's uncle, was a New Englander, "as good a specimen of Anglo-Saxon youth as England herself could boast of. He was the last descendant of a New England family, which had preserved its purity for three centuries as unmixed with continental blood as though the three centuries had been passed in the quiet vales of Devon, instead of in the New World with its broken barriers". After college, he had

2 Available at: < http://www.gutenberg.org/files/18658/18658-h/18658-h.htm_>. Accessed on June 6, 2017. 
gone to work in a shipping office in Hong Kong, "which the sickly American commerce of the day was able to support in the once flourishing China trade". There, in the course of time, he had met Priscilla, orphaned offspring of a New England couple, who had been brought up in Macau by her aunt, the second wife of Dom Luiz de Amaral, a local grandee: "it was a strange transplanting for such a flower from the cold coast of Puritan New England to the tropical, Roman Catholic colony in the heart of heathendom. But the flower of so sturdy stock remained true".

It had long been assumed that Priscilla would marry Dom Luiz's son, Dom Pedro de Amaral, by his first marriage to a Spanish woman. We can only guess why Gunnison had made D. Pedro half-Spanish, but that old stereotype of passion and violence was readily available, and while Macau was a Portuguese colony, the stereotype could be transferred with impunity by the agents of a culture that saw little, if any difference, between Portuguese and Spaniards. As we shall see, the use of the stereotype may indeed have had wider geopolitical ramifications. However, to return to the plot, Priscilla had been introduced to the wider world of Hong Kong by her foster parents, and it was there that she met Robert: "There were many disappointed youths and envious of Robert Adams, but all took their misfortune as in the way of the world, except young Amaral, who, in silence, had watched the course of events and now hated the happy suitor with all the fierceness of his Southern blood".

The situation is complicated by the fact that Adams is a friend of the Amaral family. D. Luiz's fortune has been built on his wise investments in Hong Kong and in trade, unlike most of his fellow citizens who live in poverty and pride, including his son, who is an inveterate gambler. It is on one such gambling expedition that D. Pedro persuades Robert, who is visiting 
Priscilla, by now his fiancée, to join him. After their visit to the gambling den, Robert decides to take a late night stroll among the ruins of St Paul's Church, where he is set upon and stabbed in the arm with a poisoned dagger, creating a stir in Macau not felt since the assassination of the Governor Amaral ${ }^{3}$.

The same night, Priscilla mysteriously disappears. Robert has to have his arm amputated, and after some weeks, during which time there is no news of his betrothed, the now recovered Robert receives a cryptic message instructing him to make for a junk anchored in the harbour. There he finds Priscilla, while he himself has been lured there by D. Pedro, his sweetheart's kidnapper. D. Pedro's intention is to force a marriage with Priscilla and, we assume, to dispose of Robert. However, at this point, nature intervenes in the form of a typhoon, which destroys the junk. Both, being good swimmers (even the one-armed Robert), the two are saved and return to D. Luiz's house. As for D. Pedro, he survives with a broken arm, but Priscilla develops a fever and eventually dies. We assume that D. Pedro, who disappears shortly afterwards to Hong Kong, either joins the priesthood, or perhaps runs away to Goa, as suggested at the beginning of the story.

There is, of course, nothing new in the figure of the sinister villain, who inhabited tales of gothic horror in the literature of the first half of the nineteenth century, but the racial/ racist references to $\mathrm{D}$. Pedro are, it could be argued, pertinent to a particular period of history. Gunnison lived through a time of transformation in his native California, and indeed in the history

3 João Maria Ferreira do Amaral (1803-1849) was a Portuguese naval officer appointed to the governorship of Macau in 1846. He pursued policies that were seen by the regional Chinese elite as hostile to their interests, and was assassinated in 1849. News of his death shocked the colonial authorities of Macau and Hong Kong, and the publicity given to the event may be why Gunnison used the family name in his story. 
of the United States and its relationship with what might broadly be termed, the Iberian and Ibero-American world. The year 1848 witnessed the formal surrender by Mexico of California to the United States, as a result of the US-Mexican War (18461848). The opening up of the North American western seaboard to a rapidly expansive United States paved the way for further incursions into the Pacific, culminating in the seizure of the Philippines in 1898 resulting from the brief war with Spain. If, in parallel to this, we also consider the establishment of Hong Kong as a British colony in 1841, which severely dented the historic prestige of Portuguese Macau as the only European entrepot in China, then we could regard the second half of the nineteenth century as a period of unbridled Anglo-American capitalist expansion at the expense of the older Iberian empires in the Western Pacific and South China Sea. It is important to bear this process in mind when reading 'In Macao', for it explains the stereotyped portrayals of Robert, "as good a specimen of AngloSaxon youth as England herself could boast of" and of Pedro de Amaral, his failed rival for the hand of Priscilla, who "bent upon him such a look of hatred as only the eyes of Latin races can give", and "hated the happy suitor with all the fierceness of his Southern blood". This hatred is accentuated by the fact that Priscilla has been brought up in Macau. Robert is therefore the rescuer of one of his own stock from the threat of race mixture.

A brief look at two of Gunnison's other short stories available in the same volume as 'In Macao' places him well within the vein of romantic Indianism associated in North America with figures such as Fennimore Cooper, and in South America with the Brazilian, José de Alencar. 'The beautiful 
eyes of Ysidria'4 and 'A Napa Christchild'5 are both set in the author's native California, at a time before its incorporation into the United States, but when the first Yankee settlers and traders were beginning to make incursions into the area, a period that corresponded to the narrator's youth, "those merry days of California before the gold was about her dear form like prisoner's chains; before the greed of the States and England had forced us into the weary drudgery of the earth, and made us the slaves of misbegotten progress" ${ }^{\prime \prime}$. Gunnison, like both Cooper and Alencar, was ambiguous about the merits of conservation and the inevitability of progress, and it is precisely this depiction of an older world, but which is threatened by change, that is visible in the author's depiction of Macau, at once beautiful, placid and at one with Nature, but dangerous, secretive, venomous towards that or those which threaten its static order. The idea is that just as exotic beauty may conceal an underlying ugliness, the old cannot give way to the new without extracting a high price and a violent outcome: "On the yellow water here and there were junks with tanned sails and gay banners; islands with graceful pagodas were seen, and the huge white cathedral of the near dependency of Taipa. Then in the foreground at their very feet was Macao, a feast of colour, red roofs, many-hued walls, green trees and brilliant gardens, beautiful as the jewel-set sheath of a Venetian dagger, with its poison and death-dealing wickedness hidden".

This attraction to the 'Other', coupled with fear and revulsion, is a characteristic of colonial literature and of what

4 Available at: 〈https://www.gutenberg.org/ebooks/18660〉. Accesed on June 6, 2017.

5 Available at: 〈https://www.gutenberg.org/ebooks/18725〉. Accessed on June 6, 2017.

6 'The beautiful eyes of Ysidria'. 
we now understand by the blanket term Orientalism, and this is most tangibly reflected in the figure of the male 'Other', who, in accordance with the morality of the colonizer, is feminized. Nowhere is this more clearly reflected in the figure of the open, honest, upright Robert Adams, on the one hand, and the emotional but devious Pedro de Amaral on the other, and in the former's upbraiding of the latter during his brief imprisonment on the junk: "I thought you my friend, Dom Pedro, and I thought you a man (my stress)". If Robert and Priscilla, the archetypal innocent victim, are saved from the vengeance of Dom Pedro by a typhoon, this excess of Nature merely serves as a metaphor for the violence and chaos of Dom Pedro's 'Otherness'. Equally, Robert's replacement of Pedro as Dom Luiz de Amaral's trusted adviser and honorary son seems to suggest a type of compromise at the end between old fashioned concepts of honour and decency enshrined in the decadent Pedro's father, who significantly, has made shrewd investments in Hong Kong to ensure his position in Macao's wealthy elite, and progressive capitalism enshrined in Robert, the young, "pure-blooded" Anglo-Saxon New Englander, drawn to the East by the opportunities afforded by Hong Kong. However, the long arm of vengeance impedes even this new association, and the scene of departure at the end of the story seems to throw into relief Macau's general abandonment and stasis, which of course, have been commented on throughout the tale, with references to Macau as a "drowsy city", whose residents sleep during the week and awaken on Sundays, a timetable diametrically opposed to that of puritanical, Protestant capitalism. 


\section{The Oriental(ized) Portuguese female}

We now move on to the figure of the 'orientalized' Portuguese female, while also fast-forwarding seventy years to the Hong Kong of James Clavell. Clavell (1924-94) was a British writer, now remembered mainly for his blockbuster novels set in East Asia, most of which were turned into films or TV miniseries. In fact, Clavell settled in Hollywood in the early 1950s, and became a film scriptwriter, counting among his major successes, 'The Great Escape' and 'To Sir with Love'. The links between the cinema and stereotypical characterization will be returned to later, but for now, suffice to say that the novel that interests us here is Noble House (1981). Noble House is a sequel to Clavell's earlier novel, Tai-Pan, which was set in Hong Kong in the 1840s, and traced the emergence of two trading houses, and two bitter rivals for commercial hegemony, Dirk Struan and Tyler Brock, the founders of enterprises loosely based on the real life Hong Kong trading houses of Jardine-Mathieson and Butterfield \& Swire. Hong Kong in the early 1960s is of course, very different and far more complex. Ian Dunross is now 'tai-pan', or chief executive of Struan's, and family rivalry with Rothwell-Gornt, led by Quillan Gornt, a descendant of Tyler Brock, still forms the central pivot for all that happens. Against a general background of espionage and counter-espionage (we are at the height of the Cold War - the Cuban missile crisis, US involvement in Vietnam, the Profumo scandal), and Triad activity, Struan-Gornt rivalry is spiced up by the arrival of two American entrepreneurs, Linc Bartlett, buccaneering president of Par-Con Industries and his vice-president, Casey Tchulok, with whom he is rumoured to be sexually involved. Bartlett is in Hong Kong to seek investment partners and to make a quick profit out of the Hong Kong boom, 
but he is undecided whether to invest in Gornt or in Struan. Both are potentially willing partners, Struan because he is overstretched as always with loans to repay, Gornt because he sees Bartlett as a conduit to his taking over Struan's and becoming the one and only 'tai-pan', much as his nineteenth-century ancestor had tried and failed to become. In his effort to win over Bartlett to the Gornt camp, Quillan deploys his most seductive weapon: Orlanda Ramos. Orlanda is the daughter of a Chinese mother and a Portuguese father from Macau. Born in Shanghai, she was sold to Quillan by her indebted parents, as a 'mui jai' (in effect, a slave girl). Educated in the United States until she was eighteen, she had returned to China to become Quillan's mistress, and even though they are no longer romantically involved with each other, she remains dependent on him.

Orlanda is not unlike generations of 'mestizo' women portrayed in Latin American literature. Morally ambiguous, we are never sure whether her seduction of Linc Bartlett is to secure her own position with Gornt, or done out of genuine attraction for the American, or whether it is the offer of rewards from Gornt: if she succeeds in becoming his mistress, she will get a Jaguar and the flat she lives in in Hong Kong, if she becomes his wife, she will get the additional reward of a house in San Francisco. On the other hand, all the characters in the book are driven by the pursuit of material gain, and prostitution is merely a way in which women can get a slice of wealth produced by men. In a world where women are enslaved by men, then Orlanda's pursuit of Bartlett can be seen as an act, which, if successful, will free her from Gornt, but of course, only to become a slave of Bartlett. And this is where Orlanda, the sex puppet, becomes the tragic slave woman. Firstly, we are made aware that she had a child by Gornt, now being raised in Portugal, to where her family 
fled after the fall of Shanghai to the Communists in 1949. The separation of mother and child within slavery was a trope that anti-slavery writers in the New World used in literature in the second half of the nineteenth century in order to emphasize the inhumanity of the institution. In Orlanda, there is still a dream of reconciling the pieces of her shattered world, by taking Bartlett one day to visit her family in Portugal, by freeing herself from the limiting label of being classified in the strict social hierarchy of colonial Hong Kong as a Eurasian, and by escaping her past and disappearing into the American melting-pot, where one's ethnic origin can be forgotten or re-invented. Orlanda's tragedy is that she seeks to throw off the shackles of the stereotype that she has been forced to accept of herself.

The ultimate tragedy is one of irony. At the onset of a devastating typhoon, Orlanda and Linc eventually 'pillow' (the term used locally throughout the book meaning to have sex). As Bartlett, sleeps in her bed, Orlanda goes out to buy some food, only for the apartment block to collapse when it is hit by a landslide. As attempts are made to rescue him, a further slide obliterates the remains of the building, and the American dies. This not only shatters Orlanda's dream, but also symbolically marks the end of Gornt's dream to take over Struan's. The tower block was one of the first to be put up in the post-war boom by Gornt, with uninterrupted views of the harbour. Struan had put up another skyscraper partially blocking this view, much to his business rival's resentment, but the fact that Struan's concrete phallus survives and Gornt's does not seems to reflect the outcome of the story, namely Gornt's ultimate failure to topple Dunross.

But perhaps the greatest irony in this story is that Orlanda's real guardian angel is in fact another woman, 
her supposed love rival, Casey. It is Casey, the embodiment of American beauty, athleticism, and the values of venture capitalism, who saves Orlanda's life during a fire on a floating restaurant when it transpires that the terrified Orlanda cannot swim. It is Casey who goes to meet Orlanda after the final tragedy. Orlanda has succumbed to what is seen as native fatalism: "Joss about Linc, she told herself for the ten thousandth time. Joss. Now everything's as before. Everything has to start again. The gods laughed at me again. Perhaps there'll be another chance of course there'll be another chance. There are other men... Oh God! Don't worry, everything will be as it was. Quillan said not to worry, my allowance would contin" (CLAVELL, 1981, p. 1276).

Casey, who has made a large amount of money on the side, unbeknown to Bartlett, in a separate deal with Dunross, suggests a way out for her:

"on a sudden impulse Casey said, 'Why not try the States? Maybe I could help you find a job'.

'What?'

'Yes. Perhaps in fashion - I don't know what exactly but I'll try'.

Orlanda was staring at her incredulously. 'You'd help me, really help me?'

'Yes'. Casey put the envelope and her card on the table and got up, her whole body aching. 'I'll try'.” (CLAVELL, 1981, p. 1278)

Whether Orlanda will take her up on her offer or fall back into dependency on Gornt is left open at the end of the novel, while Casey returns to America. The film version has a 
less ambiguous ending, in keeping with romantic Hollywood convention: Orlanda is left with Quillan, while Casey has a brief affair with Dunross (appropriately played by Pierce Brosnan), promising to return to Hong Kong. Hollywood therefore maintains the nineteenth-century literary convention of punishing the ambitious, dark-skinned female for aspiring to rise beyond her station, while rewarding the light-skinned female with the possibility of the male hero's hand.

The two stereotypes we have considered here, the orientalized 'Portuguese' male and female emerged out of history, like other stereotyped images, the history of European colonialism and colonial rivalry. But they linger on after their time has passed. The excessively formal, phlegmatic Englishman, such a figure of fun among continental Europeans, seems as out of place now in our globalized age, as does the vindictive Latin. Moreover, there is evidence to suggest that in the late medieval and early Tudor periods, life was as violent and licentious as that stereotyped in later English depictions of foreign countries. The formal, efficient and moralistic Englishman emerged during Britain's imperial expansion, and was an English creation in so far as it embodied qualities inculcated in the male pupils of its elite schools, precisely those who would become the political leaders and administrative officials of empire. The same culture, in its own rivalry with Southern Europe, created the venal, immoral, vindictive foreigner, and in its religious scorn was clearly an arm of Protestant nationalism. The so-called Britain of the 'stiff upper lip' became redundant with the end of empire and the destabilising of older more deferential values during that watershed decade of the 1960s, when the social mobility facilitated by the welfare state, and state education system instituted after the Second World War, saw a first generation 
come of age and take on some of the values of 'rock' culture emanating from the United States.

\section{Orientalized Portuguese for Postmodernity}

If Europe has changed out of all recognition since the end of empire, stereotypes continue to abound in popular culture, a popular culture dominated now, no longer by the printed word, but by cinema (we only have to think of Hollywoodian visions of aristocratic Britain and the British that are totally dated, not to mention stereotypes of Latin Americans). The 2012 James Bond movie, 'Skyfall', takes us back to Shanghai and Macau as Bond (played by Daniel Craig) is sent to pursue the villain who has succeeded in destroying the headquarters of MI5 in London by some form of computerized remote control. From Shanghai, Bond is led to Macau by the discovery of a gambling chip found on a dead body. In a Macau casino, he encounters Sévérine (played by the Franco-Chinese actress Bérénice Marlohe), enslaved to the sex trade and to the villain, Silva, alias Tiago Rodrigues (played by Javier Bardem). Sévérine could be Orlanda, as she lures Bond to the offshore island that has been taken over by Silva in the hope that he might save her from her enslavement, Silva could be Pedro de Amaral from Gunnison's story, driven by a lust for vengeance against a world he feels has treated him badly. Silva's rancour is a measure of his inability to behave like a man - that is, to show a stiff upper lip. There is, however, a difference between the portrayals of Silva and Sévérine in the Bond film, and that of the earlier literary models considered above.

Despite the circumstantial link with Macau, their Portuguese identity is never mentioned, but somehow assumed. 
They are orientalized Latins who are Portuguese by geographical association or by name. Silva's identity is fluid, including his sexuality, as witnessed in his implied gay propositioning of his briefly imprisoned Bond. He was an MI5 operative in Hong Kong between 1986 and 1997, significantly the year of the handover of the territory to China. Silva may well be a Hong Kong Portuguese. Sam Mendes, who directed 'Skyfall' is himself from a Trinidadian family of Portuguese background, and would have been aware of the presence of people of Portuguese origin resident in the British colonial world. Abandoned by his employers, Silva's bitterness is turned against the British Empire and what he sees as Bond's misguided attachment to country. He seeks to seduce him, in an openly homo-erotic moment of behaviour, away from traditional concepts of patriotism and manhood. Silva is a de-racinated, postmodern orientalized Portuguese for the international world of internet technology and globalization, but the familiar basis of the stereotype, notably vindictiveness and brutality, is nevertheless present.

Finally, it would be untrue to suggest that Northern European imperial hubris went unanswered by its Southern European rivals. The fact is that all colonial nations extolled their own exceptionality in the great imperial contest. At about the same time that the elite schools of Britain were training the future administrators of the colonial empire in the virtues of stoicism and detachment, a Brazilian sociologist, Gilberto Freyre, was embarking on a social and cultural history of slavery in the North East of his country that would eventually lead to his re-interpretation of the nature and qualities of Portuguese colonialism, not only in Brazil, but in Africa and in Asia. Ultimately, what was to become the theory of Luso-Tropicalism turned some of the negative stereotypes of Portuguese colonialism 
as propounded by the British into essentialist, positive qualities: informality, unbridled sexual activity, and the blurring of social and cultural boundaries between colonizer and colonized through miscegenation. In the final stages of the Portuguese Empire, the exceptional quality of Portuguese colonialism, according to the political narrative of Lisbon, once it took on board Freyre's theories, lay in the selective 'orientalization' of its colonial agents as an antidote to that which was perceived as rival British arrogance, exclusiveness and ultimate colonial failure.

\section{References}

Allport, G. W. The nature of prejudice. Cambridge MA:

Addison-Wesley, 1954.

Glavell, James. Noble House. London: Hodder \& Stoughton, 1981.

PugA, Rogério. The picturesqueness of sleepy Macao: singularity of space in a short story by Charles A. Gunnison. Oriente, n. 1, v. 1, p. 108-118, 2001.

SHaw, D. In Macao: Charles A. Gunnison's gothic tale. Journal of the Macao Polytechnic Institute, n. 5, p. 31-38, 2011.

Brookshaw, David. Oriental(ized) Portuguese - anglophone literature, culture, and colonial stereotypes. In: Simas, Monica (Org.). Estudos sobre Macau e outros orientes. São Paulo: Paulistana, 2017. p. 95-110. 


\section{Wenceslau de Moraes, suas obras e o serviço exterior português na Ásia ${ }^{1}$}

\section{Sérgio Pereira ANTUNES ${ }^{2}$}

Wenceslau de Moraes, um dos poucos escritores do universo da língua portuguesa que conseguiu se despir de preconceitos de branquidade e viveu intensamente o mundo oriental, coloca-se ao lado de grandes personalidades universais a exemplo do francês Paul Gauguin e do norte-americano Lafcadia Hearn (FonsECA, 2003, p. 9).

Wenceslau de Moraes é fruto de um contexto marcado por importantes mudanças da história universal e, por consequência, traz sua vida imbuída de transformações observadas, anotadas e criativamente narradas em suas obras, refletindo a

1 Versão deste texto foi publicada na Revista de Cultura, Macau, n. 49, p.35-43, 2015. Edição Internacional.

2 Graduando em Economia pela Pontifícia Universidade Católica de São Paulo e em Direito e Letras pela Universidade de São Paulo. Mestre em Integração da América Latina, Doutor em História Econômica e Pós-doutorado em Direito Constitucional Comparado e em Cultura Chinesa, pela Universidade de São Paulo. Membro do Grupo de Pesquisa Pt Oriente e do Laboratório de Interlocuções com a Ásia (LIA); santunes@usp.br 
compreensão do universo oriental que quis voluntária e profundamente conhecer.

Foi também por meio das observações narradas por Wenceslau, com exímia beleza literária, que o mundo ocidental, em especial o de língua portuguesa, foi brindado com importantes obras que revelam o Oriente por um testemunho ocular. Delas vale lembrar: Traços do Extremo Oriente (1895) - obra que apresenta as primeiras sensações em terras de exótica beleza por toda Ásia, destacando Macau, China e Japão; Paisagens da China e do Japão (1906) - obra mais madura explorando e revelando ao ocidente contos, lendas e fábulas imemoriais do Oriente; Dai Nippon (1897), talvez a mais completa obra a tratar do mundo nipônico; entre outras tantas obras dedicadas à cultura do extremo oriente.

Pelas observações traçadas por Wenceslau de Moraes, em suas obras, podemos compreender a dedicação do oficial da marinha portuguesa no cumprimento de importantes missões e inestimável apoio para as políticas externas do governo português.

Assim, para a adequada compreensão da importância de Wenceslau de Moraes no quadro proposto, parece-nos recomendável averiguar o contexto histórico de sua época; traçar, brevemente, aspectos de sua vida e de sua carreira; delinear características essenciais de algumas obras; e, por fim, analisar o conteúdo de cariz diplomático com que Wenceslau brindava seus leitores, descortinando o mundo oriental daquela época.

\section{Contexto histórico}

O século XIX assistiu a uma inédita evolução da sociedade em diferentes campos, desde o tecnológico, o social, até o econômico, que mudou o rumo da própria história mundial. 
No contexto mundial, a história revela o espraiamento da Revolução Industrial iniciada na Inglaterra no século XVIII, bem como o seu reflexo no ordenamento econômico internacional. A industrialização da Inglaterra e de outras nações criou um excedente de produção que, em princípio, não encontrou a prontidão de um mercado consumidor. Assim, o enriquecimento e o poder econômico dessas nações dependiam da criação de um mercado favorável, que só pôde ser construído com a imposição de tratados desiguais, nos moldes do pioneiro tratado de abertura dos portos brasileiros às nações amigas, ou seja, o Tratado de Amizade e Comércio.

As rotas comerciais também se alteraram. Desde a inauguração e abertura à navegação internacional do Canal de Suez, não era mais necessário contornar a África para a Europa alcançar o Extremo Oriente. Da mesma forma, a evolução tecnológica aparelhou as embarcações com equipamentos mais precisos de navegação além de torná-las mais seguras. As naus de madeira com mastros e velas foram substituídas por embarcações com casco de metal e motores propulsores. Novas atividades econômicas emergiram: surgiram o turismo e o interesse por conhecer novos lugares, em especial aqueles exóticos, que passam a ser muito explorados pela literatura especializada a exemplo das narrativas de viagem. Surgiram, então, as companhias de turismo, os hotéis de luxo e todo o aparato de apoio necessário a essa atividade. No final do século XIX, o turismo contava já com o poder de uma máquina maravilhosa: a câmara fotográfica. A dependência pelos produtos orientais, em especial os artesanais, passou a ser relativizada ante a possibilidade de substituição pelos produtos criados pela Revolução Industrial.

Portugal também assistiu, nesse período, a uma série de mudanças. No início do século XIX, as guerras napoleônicas 
levaram a sede da metrópole portuguesa para terras brasileiras. Mais tarde, em 1822, com a independência do Brasil, Portugal perdeu uma importante parcela de sua economia. Restou, então, transformar suas demais colônias em um "grande Brasill". Para novos processos de exploração e de atendimento do interesse econômico, novas políticas foram lançadas em face de Angola, Moçambique, outros pequenos territórios na África (Cabo Verde, São Tomé e Príncipe, Guiné Bissau), os territórios coloniais na Índia (Goa, Damão e Diu, já que havia negociado e cedido Bombaim para a Inglaterra), e os longínquos territórios de Macau e Timor.

A China, por sua vez, até 1840, dominava a ordem econômica mundial como o grande fornecedor da economia global e hegemonia em toda a Ásia. Entretanto, a partir da I Guerra do Ópio, perpetrada pela Inglaterra, cujo desfecho se deu com a assinatura de um tratado desigual (Tratado de Amizade e Comércio), impondo à China a cessão da ilha de Hong Kong e a possibilidade de estabelecimento comercial inglês em território chinês sob jurisdição britânica, além do livre comércio de benefício unilateral. Tais medidas acabaram por levar a China a uma estagnação econômica inédita e uma severa crise social nunca antes vistas. Outras potências imperialistas (Estados Unidos da América, Países Baixos, França, etc.) seguiram e se aproveitaram dos passos britânicos em face à China, piorando sua situação econômica e social. Se, no começo do século XIX, a China tinha a hegemonia econômica no Oriente, ao final desse mesmo século, restou-lhe assistir ao crescimento dos imperialistas, incluindo o Japão, com pretensões hegemônicas na região.

Nesse contexto, a autonomia de Macau perante a China torna o território uma verdadeira colônia portuguesa. Fato que impingiu a Portugal o incremento de sua presença, tendo, a partir da assinatura do Tratado de Amizade e Comércio Sino-portu- 
guês, de administrar o território e toda a sua gente, não só os portugueses e estrangeiros, mas também os chineses. É desse período a introdução de escolas luso-chinesas. Além disso, a língua portuguesa passou a ser ensinada aos chineses, o território ganhou seu primeiro instituto de ensino médio, o Liceu de Macau, e fluíram para Macau altos funcionários da coroa portuguesa: juízes, agentes aduaneiros, professores, imprensa, etc. Assim, embora Macau tenha que compartilhar sua hegemonia do comércio sino-internacional com Hong Kong, acaba recebendo atenção de Portugal.

\section{Aspectos da vida e da carreira de Wenceslau de Moraes: Marinha e Macau}

Wenceslau de Moraes, nascido em 1854, assistiu a essa transformação histórica. Ingressou na Escola Naval em 1872 e logo se engajou na Marinha Portuguesa, que também assistia à evolução tecnológica daquele século. Tanto que Wenceslau iniciou, em 1874, sua carreira, embarcado na Corveta Bartolomeu Dias - uma embarcação simplória de casco de madeira e ainda movido pela força do vento. No correr dos anos, assumiu postos embarcado em navios cada vez mais evoluídos, chegando a Macau servindo como oficial na Canhoneira Rio Lima, uma embarcação encouraçada e moderna.

Nem só de tecnologia evoluía a Marinha, eis que, com a independência do Brasil e a necessidade de Portugal fazer de suas demais colônias um grande Brasil, conforme vimos, a Marinha Portuguesa foi incumbida de nova missão, tornando-se o abraço executivo das relações exteriores e da diplomacia portuguesa.

Assim, a Marinha marca a formação e a vida de Wenceslau de Moraes, que faz uma carreira de marítimo, mas também de diplomata. 
Macau igualmente marcou a formação, a vida e, sem dúvida, o ponto de partida para o processo de orientalização de Wenceslau de Moraes. Foi em Macau que, pela primeira vez em sua carreira na Marinha Portuguesa, assumiu um cargo em terra firme. Foi, por consequência, em Macau que fixou residência, montou seu lar, casou, teve seus dois filhos, lecionou, participou ativamente da vida social do lugar, fez várias viagens ao Japão, apaixonando-se pela cultura nipônica, escreveu e de lá fez publicar seus dois primeiros livros Traços do Extremo Oriente e Dai Nippon.

Foi também em Macau, que Wenceslau se decepcionou com a Marinha. Por se sentir preterido na nomeação do Superintendente do Porto, pediu exoneração e decidiu a grande guinada de sua vida, abandonando tudo e seguindo só para o Japão com intento claramente de orientalização.

\section{Entre as obras de Wenceslau de Moraes, algumas características}

Wenceslau de Moraes escreveu grande gama de obras literárias que revela as complexas relações internacionais de sua época. Nesse complexo contexto, o autor trata do universo chinês, destacada e expressamente, em duas de suas obras: Traços do Extremo Oriente e Paisagens da China e do Japão.

É na obra Traços do Extremo Oriente que os primeiros contatos orientais são reportados e há, portanto, importantes informações sobre a Tailândia, Singapura e Indonésia. Todas essas paragens são cenários de seus contos e de suas narrativas de viagem. O Japão predomina a maior parte de sua obra, que é composta de várias publicações de peso, além de Traços do Extremo Oriente, de 1895, e Paisagens da China e do Japão, de 1906; Dai Nippon, 
em 1897; Cartas do Japão, em 1904; O culto do chá, em 1905; O Bom-Odori de Tokushima, em 1916; O-Yone e Ko-Haru, em 1923; Fernão Mendes Pinto no Japão, em 1920; Relance da História do Japão, em 1924; Os Serões no Japão e Relance da Alma Japonesa, ambas em 1926.

Traços do Extremo Oriente, o primeiro livro de Wenceslau de Moraes, que veio a ser publicado em Lisboa em 1895, apresenta características peculiares. Escrito aos moldes das narrativas de viagem, descrevendo rotas, lugares e paisagens, tem o narrador presente e que, com alguma cerimônia, dialoga com o leitor. A referida obra é composta por uma carta dirigida a sua irmã e por vários contos escritos e recolhidos pelo autor desde 1885. Além de um post scriptum e um conto tratando de Batávia, a capital holandesa da ilha de Java (hoje Jacarta). A obra está dividida em três partes: as "Recordações do Sião", "Lembranças da China" e "Saudades do Japão". Por esses subtítulos, já se percebe sua predileção peloJapão, uma vez que dali tem saudades, da China, só lembranças e da Tailândia, recordações.

A obra Paisagens da China e do Japão, publicada em 1906, também tem suas peculiaridades. O teor da escrita revela um amadurecimento acerca do conhecimento daquelas paragens orientais. No contexto das obras produzidas para leitores ocidentais de língua portuguesa, seu teor é de extrema importância, eis que traz à luz do universo lusófono contos e lendas do mundo chinês e japonês, sendo que muitos deles, até hoje, são obras únicas a respeito desse imaginário literário oriental. A obra congrega 17 contos, tratando especificamente da China e do Japão, sendo que, em três deles, o ambiente do enredo é Macau: a) "O ano novo"; b) "Pau-Man-Chen"; e c) "Amores".

Em ambas as obras aqui tratadas (Traços do Extremo Oriente e Paisagens da China e do Japão), podemos observar que: a) o ambiente é oriental (Tailândia, Indonésia, Singapura, Macau, 
Hong Kong, China, Japão); b) os personagens se assemelham são chineses ou japoneses (orientais no geral), europeus, e elementos culturais que acabam sendo tratados como personagens; c) há qualificações pejorativas, quase sempre vinculadas à China, e qualificações próprias de exaltação, quando trata de Macau e Japão.

A respeito das menções feitas a Macau, em Traços do Extremo Oriente, encontramos adjetivações interessantes: "pequenino", "dia belo, montanhas doiradas pelo Sol", "boa gente chinesa", "existência fácil, clima salubre", "viver modesto... ingênuo e bom", "encosta coberta de relva, um veio de águas límpidas". Em Paisagens da China e do Japão, Macau é igualmente bem referido: "um canto exótico, longe muito longe do torrão em que nasceu”, “... a brandura dos costumes".

Em ambas as obras, Macau aparece como um longínquo território português na Ásia: "Portas do Cerco, limite de nosso domínio colonial", "Pequenino Macau português", "Macau, onde, pela primeira vez, a raça branca implantou poderes no império" (Moraes, 2012), e "Aqui no fim do mundo, no seio desta colônia nostálgica", "exíguo penedo asiático, onde Portugal implantou a sua bandeira" (Moraes, 2007).

Macau, entretanto, na obra Traços do Extremo Oriente, é também referido como um território chinês: "esse pobre torrão chinês onde me encontro". O mesmo não acontece em Paisagens da China e do Japão, onde apenas referência a Macau portuguesa foi localizada.

\section{Conteúdo diplomático na obra de Wenceslau: serviço exterior português}

Como já dissemos, Wenceslau de Moraes é produto do contesto histórico de sua época. Logo cedo em sua carreira de 
oficial da Marinha, abraçou e desempenhou a missão atribuída àquela força armada de ser o braço executivo das políticas externas portuguesas, lidando em suas funções com a plena realização do serviço exterior português.

No desempenho dessas funções, vale lembrar suas primeiras ações, à semelhança dos atos próprios do serviço exterior, embora não fosse à época funcionário diplomático ou mesmo de generalidade das funções dos negócios estrangeiros. Assim, participou da celebração do Tratado de Amizade com o Sultão de Zanzibar, em 1883.

A respeito, é interessante comentar que os tratados da espécie eram extremamente comuns à época e tiveram origem no molde daquele que pioneiramente foi assinado entre Portugal e Inglaterra, abrindo os portos do Brasil às nações amigas. Esses Tratados de Amizade e Comércio constituíram, na verdade, os expedientes que ficaram conhecidos como tratados desiguais, por não conter equidade no tratamento das partes, criando verdadeiros tratos de exclusividade e benesse para apenas um dos lados. No caso brasileiro, a abertura dos portos às nações amigas, em princípio, teve única e exclusivamente a Inglaterra como beneficiária.

Esses tratados se espalharam pelo mundo criando os privilégios dos europeus e americanos na construção da hegemonia mundial, consolidando o imperialismo em detrimento das demais partes, que ficaram reduzidas a uma segunda categoria de nações.

Como homem de seu tempo, Wenceslau, por seu tino diplomático e humanista, identifica muito bem a problemática desse período, o abuso europeu baseado nos canhões ou nos tratados da espécie. Consciência que revela com clareza em Paisagens da China e do Japão: 
[...] período de frenesi da Europa, de curiosidade, de cobiça, em face da morna inércia deste canto do mundo; e as esquadras que o devassam, que o visam com os canhões; e os diplomatas que intrigam, que teimam, conduzindo-o finalmente, à força, ao convívio das nações. (MORAEs, 2007, p. 101)

Igualmente, Wenceslau de Moraes atuou na representação de Portugal em sua visita ao Reino do Sião (atual Tailândia), como ficou muito bem registrada no conto "Em Bangkok" (Banguecoque), no capítulo "Recordações do Sião" de sua obra Traços do Extremo Oriente. Ali Wenceslau reporta essa visita em detalhes ao ser recebido por amável príncipe, já que Sua Majestade Somdetch P'ra Paramindr Mahah Chulalongkorn estava ausente, e ilustra, ainda, seu olhar europeu sobre os costumes exóticos, relatando o ataque de um felino de estimação no Palácio Real.

Uma curiosidade a observar é um soberbo leopardo, solto, livre, passeando ao seu sabor, aproximando-se de nós, fixando-nos por vezes as suas pupilas nostálgicas. _ "Manso como um gatinho" - é a frase de sua alteza. No entanto o dulcíssimo animal encara de quando em quando, carrancudo, os grupos de escravos quase nus, que enxameiam nos vestíbulos. Provoca risos o seu mau humor. Uma mulher, por brincadeira empurra para frente um rapaz que está próximo. O rapaz solta uma gargalhada. O leopardo, ao que parece, não gosta de gargalhadas; dá dois pulos, chameja-lhe o olhar. $\mathrm{O}$ rapaz foge, a rir-se ainda; e o leopardo avança em ondulações, sem ruído, com patas de veludo; envolve-se 
com ele, abraça-o, rasga-lhe as carnes, deixa-o morto. (Moraes, 2012, p. 11)

É também em Traços do Extremo Oriente que Wenceslau nos reporta muito sobre o Japão, cumprindo missões governamentais: em 1889, a primeira de importância; em 1892, quando foi ao Japão para aquisição de defesa para Macau; depois, em 1894 e em 1897, quando, na companhia do Governador de Macau, foi recebido pelo Imperador do Japão, momento raro da diplomacia portuguesa.

A título ilustrativo, basta lembrar a descrição feita por Wenceslau sobre Yokohama, demonstrando a forte presença estrangeira e consignando a ausência do outrora pujante comércio português que, no século XVI, havia inaugurado essa atividade internacional por aquelas terras nipônicas:

Ingleses, americanos, franceses, chineses, judeus, vendilhões de todo o mundo, invadiram há já longos anos o país, e aqui assentaram de preferência arraiais, para estendal dos seus produtos e colheita dos alheios; abrindo ruas, erguendo edifícios - habitações, armazéns, fábricas, - com a feição cosmopolita duma babel qualquer comercial. Aqui é um hotel, ali um clube, além um campo do tennis ou uma igreja protestante; e casinhas entre jardins, garridas, no gosto britânico. Mas nada disto é japonês; nem quase japonês é este povo, descaracterizado pelo contato com estranhos... (Moraes, 2012, p. 166)

Essa abertura comercial e a presença marcante do mundo ocidental em Yokohama são explicadas por Wenceslau, em 
Paisagens da China e do Japão, onde resta bem claro que tal poderio estrangeiro em terras do Oriente, mais uma vez, só foi conseguido por tratados desiguais, ou seja, pelos Tratados de Amizade e Comércio celebrados:

O shogun, generalíssimo do imperador, com residência em Yedo, assinara por conta própria tratados de amizade e de comércio com a América e com a Europa, e os estrangeiros, em Yokohama, pisavam já afoitamente o solo japonês. (MoRAEs, p. 114)

\section{É em Traços do Extremo Oriente que Wenceslau representa e apresenta seu país ao Oriente:}

[...] pergunta-me se o meu país é um poderosíssimo estado. Digo-lhe que não, o que ele bem sabe; e acrescento que já o fora.

- Sim, - acode-me o garoto com ares de profeta, - é a sorte das nações. Portugal já foi o primeiro país do mundo; hoje é a Inglaterra; amanhã será a Rússia; depois de amanhã será o Japão. (Moraes, 2012, p. 259)

Talvez o mais importante a se destacar nos escritos de Wenceslau é sua diplomacia humanitária, quando, por exemplo, dá a receita para os imperialistas alcançarem admiração por uma vertente mais humana:

[...] ódio intransigente que todo o chinês vota aos europeus...

Foi nesse meio tão insólito, que eu... me entretive a fazer brotar simpatias... Sorria-me para os bebés; afagava... 
suas mãozinhas papudas; mostrava por qualquer forma que eles me interessavam. A boca, que ia vomitar uma obscenidade, calava-se; a expressão canalha dum olhar tornava-se meiga, transluzia um agradecimento no fogo da pupila. E era tão franco o rosto que me acolhia, tão limpo de maldade, que eu iria confiante... (MORAES, 2012, p. 63-64)

Traços do Extremo Oriente é ainda importante documento histórico, eis que Wenceslau fez ali incluir a tradução da declaração da Guerra Sino Japonesa. Trata-se de um panfleto em que o Imperador do Japão conclama seus súditos a promover a guerra contra a China. E as razões? Ora às razões! Para guerra não há arrazoado plausível; assim foi também no conflito armando do Japão contra a China: não há razões ou melhor, como aquelas declaradas pelo Imperador japonês só se pode concluir a mera vontade bélica promovida pela corrida armamentista típica do período

Nós, pela graça do céu, Imperador do Japão, assentado no mesmo trono ocupado pela nossa dinastia desde tempos imemoriais, proclamamos o seguinte aos Nossos leais e bravos súditos.

Declaramos, por este, guerra contra a China, e ordenamos a cada uma e a todas as autoridades competentes, em obediência aos Nossos desejos e a fins de glória da nação, que fomentem por mar e por terra a guerra contra a China, com todos os meios ao seu dispor, conformemente as leis das nações.

Durante as passadas três décadas do Nosso reinado, o que temos sempre almejado, é o progresso pacífico 
do país por meio da civilização, e sendo sensível aos males que sempre acompanham as complicações com as potências estrangeiras, sempre foi de o nosso agrado dar instruções aos Nossos ministros de Estado a respeito das relações amigáveis com as Nossas potências dos tratados. Congratulamo-nos por saber que as relações do Nosso império com estas potências aumentaram sempre satisfatória e amigavelmente. Por aquelas circunstâncias, não estávamos preparados para uma tão evidente falta de amizade e boa fé, como há pouco manifestou a China, na sua conduta para com este país, concernente à questão coreana.

A Coreia é um estado independente. Mereceu ela entrar no grêmio das nações, aconselhada e guiada pelo Japão. Foi, contudo, costume da China designar a Coreia como dependência sua, e os impérios japonês e chinês interferiram nos seus negócios, tanto aberta como secretamente. Por ocasião da última rebelião civil da Coreia, a China enviou para ali tropas, alegando ser propósito seu defender um estado seu dependente. Nós, em virtude do tratado concluído com a Coreia cm 1882, e olhando a acontecimentos futuros, ordenamos também que se enviasse para aquele país uma força militar. Desejando procurar que a Coreia esteja para sempre isenta de perpétuos distúrbios, e por isso manter também a paz do Oriente em geral, o Japão convidou a China a cooperar com ele para a realização deste fim. A China, porém, alegando vários pretextos, recusou o convite do Japão. Depois disso o Japão aconselhou a Coreia a que reformasse a sua administração, de maneira a manter-se no país a ordem e a tranquilidade, podendo assim este 
reino desempenhar-se dos deveres e responsabilidades dum estado independente perante o estrangeiro. A Coreia consentiu neste Nosso desejo. Porém a China secreta e insidiosamente tem diligenciado iludir e estorvar os planos do Japão. Além disso tem procrastinado e procurado fazer preparativos bélicos tanto por mar como por terra. Depois de estes preparativos estarem prontos, não só enviou grandes reforços à Coreia a fim de forçosamente conseguir os seus desígnios ambiciosos, mas levou ainda a arbitrariedade e insolência a fazer fogo sobre os Nossos navios nas águas coreanas. O plano da China é tornar duvidoso onde reside a responsabilidade de preservar a paz e a ordem na Coreia, e não só enfraquecer a posição deste país no grêmio das nações - posição obtida para a Coreia pelos esforços do Japão - mas também obscurecer a importância dos tratados, reconhecendo e confirmando essa posição. Tal conduta por parte da China é não somente uma injúria direta aos direitos e interesses deste império, mas também uma ameaça à paz permanente e à tranquilidade do Oriente. Julgando pelas suas ações, deve concluir-se que a China, desde o princípio, se inclinou a sacrificar a paz para atingir os seus sinistros fins. Nesta situação, como é Nosso ardente desejo promover o prestígio do país no estrangeiro por métodos restritamente pacíficos, achamos impossível evitar uma formal declaração de guerra contra a China. É nosso ardente desejo que, pela lealdade e valor de Nossos bravos súditos, em breve se estabeleça a paz permanente, e que a glória do Império aumente e se complete. Dado no $1^{\circ}$. dia da oitava lua do ano $27^{\circ}$ de Meiji. (MORaes, 2012, p. 253-255) 
O cargo próprio de Wenceslau de Moraes no serviço exterior português só viria muitos anos mais tarde, em 1899, quando, por intervenção de Vicente d'Eça, seu editor e amigo, assumiu os serviços nos consulados de Kobe e Osaka, onde, em 1913, se tornaria Cônsul Geral.

Um pouco antes de sua nomeação oficial no serviço exterior, Wenceslau de Moraes atuou como honorário para a Itália. Essa ocupação, embora por curto período, revela o reconhecimento do governo italiano por seus préstimo e atitudes diplomáticas perante a colônia e cidadãos italianos junto às autoridades japonesas.

A nomeação de Wenceslau de Moraes como cônsul no Japão é consequência de uma guinada traumática de sua carreira e, por outro lado, a coroação de sua vida diplomática. É que, em 1895, por se sentir preterido na sucessão de cargos na Superintendência do Porto de Macau, Wenceslau abandonou tudo, sua casa, sua mulher e seus filhos, em Macau, e seguiu para se exilar voluntariamente em terras nipônicas que tanto lhe enchiam a alma e páginas de sua escrita.

\section{Considerações finais e conclusões}

Como vimos, a diplomacia no contexto do universo oriental aparece, por várias vezes, nas obras de Wenceslau de Moraes, e, especialmente, nas obras aqui analisadas, mais pontualmente Traços do Extremo Oriente e Paisagens da China e do Japão. As dificuldades diplomáticas do serviço exterior português também aparecem nas narrativas de Wenceslau de Moraes, onde, por exemplo, Macau é tratada ora como "o torrão português" no Extremo Oriente, ora como uma terra chinesa.

Desde seu primeiro livro, Traços do Extremo Oriente, o mundo oriental surge como um lugar explorado com grande 
curiosidade e prazer, ao início reportando didaticamente fatos demasiadamente exóticos ao olhar europeu. Com Paisagens da China e do Japão, a evolução da sua narrativa vai se complementando, compreendendo, orientalizando e se acostumando com aquele universo vis-à-vis um mundo europeu justaposto naquelas paragens. Contos, lendas, personagens e a própria vida do autor no Oriente constroem narrativas emocionantes para a compreensão do mundo asiático daquele período histórico.

A obra de Wenceslau de Moraes, além da beleza estética de sua narrativa, tem o condão de revelar ao mundo da língua portuguesa um universo oriental pitoresco que ali fica muito bem registrado como merecedor da compreensão e da efetivação de laços na construção de diplomáticas e amigáveis relações.

\section{Referências}

Fonseca, Edson Nery da. Nota do organizador. In: Freyre, Gilberto. China Tropical. Organizado por Edson Nery da Fonseca. Brasília: Editora da Universidade de Brasília; São Paulo: Imprensa Oficial, 2003.

Moraes, Wenceslau de. Paisagens da China e do Japão. Macau: COD, 2007. [1ª edição em 1906].

Moraes, Wenceslau de. Traços do Extremo Oriente. São Paulo: Sésamo, 2012. [1ª edição em 1895].

Antunes, Sérgio Pereira. Wenceslau de Moraes, suas obras e o serviço exterior português Na Ásia. In: Simas, Monica (Org.). Estudos sobre Macau e outros orientes. São Paulo: Paulistana, 2017. p. 111-127. 


\title{
No descanso eterno entre lápides e epitáfios: São Miguel Arcanjo e Consolação
}

\author{
Maria Célia LIMA-HERNANDES ${ }^{1}$ \\ Roberval TEIXEIRA e SILVA ${ }^{2}$
}

\section{Apresentação}

A cessação da vida é temida por todos, mesmo pelos cristãos que - segundo sua doutrina - irão ao encontro do Pai Eterno, mas eles não são os únicos que a temem. Entre os maometanos, por exemplo, é comum que se use uma cauda nas roupas para que seus rastros não sejam deixados na areia do deserto a fim de que a morte não os encontre (cf. Silva; Carvalho; Toledo, 1968, p. 1158).

Duas correntes antropológicas, o Difusionismo e o Migracionismo, amparam os interesses que revelamos nesta pesquisa.

\footnotetext{
Universidade de São Paulo (USP), Conselho Nacional de Desenvolvimento Científico e Tecnológico (CNPq), Fundação de Amparo à Pesquisa do Estado de São Paulo (Fapesp); mceliah@usp.br

2 Universidade de Macau; roberval.ts@gmail.com
} 
Ambas as correntes consideram que "grupos diferentes apresentam características culturais semelhantes a partir da transferência entre grupos" (Ribeiro, 2007, p. 50). A última corrente, como o próprio nome antecipa, foca a mobilidade geográfica de sujeitos, os quais passam a integrar um outro espaço em cujas rotinas e práticas sociais se inspiram, integrando-as à sua rotina. O mesmo se costuma afirmar da comunidade local, que pode absorver práticas dessa comunidade imigrante. O Difusionismo, por sua vez, prioriza a concepção de "contato cultural e imitação de um grupo por outro" (RibeIRo, 2007, p. 50).

Quem conhece Macau ou São Paulo e a dinâmica social que nessas cidades se desenha, ao tentar classificar a corrente que melhor se adequa ao caso, ficaria sem saber como tomar essa decisão, pois, a depender das experiências vivenciadas em tais espaços multiculturais, uma ou outra poderia ser atestada. Conhecer Macau e também São Paulo pressupõe viver esferas tão diversas quanto as camadas sociais (e migratórias) historicamente incorporadas (ou mesmo politicamente ignoradas) à sua população.

Em seu estudo, Ribeiro (2007) já evidenciara a importância de voltar a atenção para as práticas mortuárias como locus de reconhecimento do grau de interpenetração cultural. Considerando Macau como espaço de observação, logo nos sentimos obrigados a concordar com as descobertas de vários antropólogos que se detiveram no estudo de rituais dessa natureza: não se trata de uma mudança de uma cultura pelo contato já que "as mudanças tendem a ocorrer em ambos os grupos, o que alteraria ambas as culturas” (RiBeIro, 2007, p. 53). Também obras diversas já exibiram o choque cultural que têm lugar nessas cenas rituais. ${ }^{3}$

3 Vomero (2002) lembra o episódio "Povoado do Moinho", do filme Sonhos (1992), 
Como podemos notar e como bem afirmou Ruffié (1988), esses rituais ocupam um lugar tão especial na vida dos humanos ${ }^{4}$ que podem ser equiparados ao da sexualidade. Assim é que, para se falar de uma cultura, por assim dizer, será fundamental a observação do modo como os rituais de morte se consolidam nos diferentes grupos humanos.

Segundo Bertolli Filho e Meihi (1983), é possível analisar a temática de dois modos: por reconhecimento direto e também indireto. No primeiro caso, o fenômeno da morte é observado em sua plenitude, sem restrições, o que faz com que o investigador a focalize como núcleo de análise, como ponto de partida e de chegada. Na segunda perspectiva, alcança-se a morte por meio de discursos evasivos, suficientemente agregados de simbologia e metaforismos. É um caminho contraditório, pois, ao mesmo tempo que se busca a compreensão da morte, é a vida que assume importância suprema. É um caminho em si paradoxal, mas o fenômeno é rico em complexidades e perspectivas.

Justamente por isso, antropólogos, quando em contato com outra cultura, descrevem ritos e hábitos ligados à morte. Benedict (s.d.), por exemplo, relata que os índios Pueblo do sudoeste se preocupam em auxiliar a pessoa enlutada a esquecer a dor vivenciada e o rito é levado a cabo para esse fim:

\footnotetext{
dirigido por Akira Kurosawa, em que um forasteiro presencia um ritual funerário de um vilarejo. Ali, pessoas locais celebravam a morte de uma mulher idosa, cantando e dançando, alegremente, pelas ruas. Sentimento similar, mas às avessas, vivenciou o monge budista, Sogyal Rinpoche, autor de O livro tibetano do viver e do morrer, em seu choque com relação à forma de morrer ocidental.

4 De acordo com Ruffié (1988, p. 223), "em todas as civilizações [...] a morte está presente no centro da vida social, e notadamente através dos ritos mortuários. A comunidade toma parte no desenlace: família, vizinhos, vilarejo ou tribo assistem o moribundo[...]". "Nada de parecido nas sociedades industriais, onde a morte é cuidadosamente ocultada [...]” (Ruffié, 1988, p. 225).
} 
Reúnem-se para alimentar o morto pela última vez e despedi-lo. Um dos padres asperge todos os presentes com a água sagrada do vaso e abre a porta da casa. $\mathrm{O}$ chefe dirige-se ao morto ordenando-lhe que venha comer. Ouvem os seus passos fora, e o seu tatear à porta. O morto entra e come. Então o chefe asperge o caminho que ele agora seguirá e os padres "expulsam-no da aldeia". Levam consigo as varas-de-orar pelo morto, os artigos de vestuário e os de seu uso pessoal, a escova de cabelo e o cesto com alimentos. Levam-no para fora da aldeia, partem a escova e o vaso, enterrando tudo. Voltam a casa a correr e sem olhar para trás, e trancam a porta contra o morto, gravando nela com uma faca de silex uma cruz para evitar que ele entre, o que corresponde ao formal rompimento com o morto. O chefe fala às pessoas dizendo-lhes que o esqueçam para sempre. Despedem-se as pessoas e terminou o luto. (p. 77)

Se seguirmos lendo esses materiais da antropologia social, logo verificaremos que, em grande medida, diferem-se as culturas $^{5}$ nessas situações de enfrentamento da morte.

A posição do corpo parece ser um dado relevante para estudos dessa natureza, como demonstraram Durkheim e Mauss, ${ }^{6}$ por exemplo, mas também o papel social do morto, numa abordagem da Antropologia Social Inglesa (Funcionalismo ${ }^{7}$ ) parece

5 Em Benedict, ainda lemos sobre as peculiaridades dos Zuñi e dos Dakotas.

6 Esses autores (apud Ribeiro, 2007) mostraram que, a depender do grupo totêmico, a cabeça do morto estaria voltada para um específico ponto cardeal.

7 Essa corrente de estudos parte de pressupostos de Malinovski (1922), que priorizou o entendimento das ações humanas e do sistema social a partir de necessidades biológicas, e de Radcliffe-Brown (1922), que priorizou o entendimento do papel social dos 
ter muito a dizer sobre o que identificamos em trabalho de campo. Nessa abordagem, constatamos a correlação entre o papel social do morto e os rituais de funeral, dentre os quais a escolha do jazigo. Em São Paulo, na mesma medida e com a mesma intensidade, pode-se falar em geografia de rituais. A multiculturalidade paulistana provoca a reflexão sobre o poder e o local de ritual de 'despedida'.

Esse tema não é novo e não são ineditismos do século XX ou de sociedades multiculturais o tratamento e a diferenciação entre mortos. Desde a Idade Média, ter túmulo individual constitui-se uma deferência (RoDRIGUEs, 1999²), e também o lugar geográfico do túmulo sempre foi uma diferença básica entre alguns. Lidar, contudo, com esse tema à luz dos hábitos coloniais pode ser, de algum modo, uma perspectiva diferente e uma contribuição à reflexão sobre a construção cultural do espaço.

Os lugares que confrontamos aqui são complexamente diferentes, mas guardam um traço comum: a colonização portuguesa. Essa semelhança permite discutir aspectos culturais de Macau e de São Paulo, sob a ótica da geografia humana e, a cada recorte, uma Macau diferente se apresentará assim como uma São Paulo diferente se revelará. No entanto, se propiciarmos um mesmo recorte temático para essa aproximação, acreditamos que experiências interessantes poderão nos surpreender.

indivíduos (cf. Ribeiro, 2007).

8 "Os sepulcros privados começaram a existir primeiro dentro, depois nas adjacências das igrejas, e por fim em lugares especialmente destinados a finalidades cemiteriais. [...] Síntese desse processo: a multiplicação dos túmulos individuais de início contemplou, é óbvio, os poderosos, nobres e clérigos; em seguida, os burgueses; depois, os pequenos burgueses; finalmente, os proletários, operários e camponeses. Todos passaram lentamente a ter, não apenas a vontade, mas, ao menos em teoria, o direito a uma sepultura individual" (Rodrigues, 1999, p. 130). 
Neste capítulo, o recorte escolhido para essa dupla visitação será aquele desenhado pelos cemitérios e pela temática que os abarca melhor: a morte e seus rituais, pois, segundo Magalhães (1997, p. 147), resenhando Braet e Verbeke (1996), esse é um tema rico que permite desvendar a estrutura das mentalidades humanas ou, como queria Vovelle (1996), favorece tomar contato com o "termômetro" da sociedade, que assume um comportamento grupal frente à morte.

\section{Duas ex-colônias e suas heranças culturais}

Tanto o Brasil quanto Macau são ex-colônias portuguesas e guardam em sua sociedade traços da longa estada de portugueses e da miscigenação ocorrida. No Brasil, não se distinguem filhos de portugueses ou descendentes desses de modo marcado. Há uma distinção comum como em outra parte qualquer haveria. Invariavelmente, somente por autodenúncia é que se identifica esse sujeito, pois a miscigenação foi bastante intensa e extensa no território brasileiro.

Em Macau, dado ser um território fincado no Oriente, a diferença entre portugueses e o povo asiático, mais especificamente o chinês, é marcada. No entanto, há filhos dessa miscigenação que pouca diferença revelam pela aparência. As diferenças vão se somando, na verdade, pelos hábitos e costumes locais que são integrados de modo 'misturado' na rotina dos macaenses, filhos da terra.

As rotinas e os hábitos em contexto de féretro não são claros quanto às tradições portuguesas, razão pela qual se torna interessante conhecer como eram esses costumes na idade média em Portugal. 


\subsection{A morte e o tratamento a cadáveres na Idade Média portuguesa}

A idade do velho era principiada, na lógica da Idade Média, com os cinquenta anos ${ }^{9}$. Essa realidade permite entender que todas as ações derivadas de uma sociedade em ebulição fossem, à época, adiantadas em experienciamento ${ }^{10}$. A taxa de mortalidade era, nesse período, grande e as faixas etárias de morte, muito baixas também. Isso se devia ao "incremento das epidemias e uma menor resistência às infecções" (apud Marques, 1971, p. 219) no século XIV. Era comum que famílias perdessem filhos em idade tenra, o que elevava, sobremaneira, a mortalidade infantil. Esse evento tão frequente fez com que a Igreja assumisse um discurso sobre "o fim dos prazeres do mundo e sobre a necessidade de cada cristão meditar na passagem para a vida eterna. Daí um surto no fervor religioso e nas práticas devotas" (Marques, 1971, p. 210).

Já nessa época, os cadáveres recebiam tratamentos distintos a depender de sua categoria social. Se de família nobre, o embalsamento era feito com substâncias aromáticas, o corpo

9 Na edição de Leal Conselheiro, feita por J. Piel, em 1942 (apud MArQues, 1971, p. 209), o rei D. Duarte apresenta a distribuição de fases da vida: "e as idades são por muitas maneiras repartidas, mas uma que põem os letrados, que bem me parece, chama infância até 7 anos, puerícia até 14 , até 21 adolescência, mancebia até cinquenta, velhice até 70 , senyum até 80 , e dali até o fim da vida decrepitude."

10 D. Duarte afirma que a melhor idade para o casamento é aos 14 anos de vida. Raramente alguém ultrapassava os 70: "Dos reis de Portugal só os dois fundadores de dinastia - D. Afonso Henriques e D. João I - ultrapassaram os setenta anos. À 'velhice' apenas chegaram quatro - D. Sancho I, D. Afonso III, D. Dinis e D. Afonso IV. Os demais ficaram-se pela 'mancebia'. Com as rainhas e infantas sucedia coisa parecida" (Marques, 1971, p. 210). 
era trajado com vestimentas ricas e enfeitado com joias ${ }^{11}$. Não é preciso dizer que outras classes não recebiam esse cuidado. As classes populares adotavam um tratamento mais simples e não havia cuidados diferenciados com roupas ou tecidos.

Quanto ao local do enterro, a situação social também era critério decisivo. Eclesiásticos, senhores de grande importância social e os que em vida pagaram ou testamentaram essa forma eram sepultados dentro das igrejas. Outro caminho era o destinado aos mais simples. Invariavelmente, eram enterrados junto às igrejas em terrenos anexos denominados passais (MARQUes, 1971) ou em terrenos particulares. As valas comuns eram destinadas a servos, escravos, indigentes e menos favorecidos.

\subsection{Um panorama pré-colonial da morte no Brasil}

A colonização foi tão impactante no Brasil que os hábitos e costumes alteraram muito a padronização de usos, o que era bem diverso antes. Os rituais de morte, segundo Fontes (1976), de tribo para tribo, eram diferentes.

Na tribo Urubu-Kaapor, a morte equivale à passagem para o reino de Maíra. Já, entre os Bororo, a morte

\footnotetext{
11 "A rainha Santa Isabel, cujo corpo teve de ser conduzido de Estremoz para Coimbra, depois de amortalhada no hábito de clarissa, foi enrolada num lençol de linho fino. Sobre ele ainda se puseram uma colcha de pano mais espesso, um envólucro de linho cru, muito grosseiro, cosido à agulha, e finalmente uma outra colcha de algodão branco e grosso. Foi depois metido o cadáver num ataúde rectangular de madeira, sobre o qual se pregou para maior resguardo um couro de boi com o pelo voltado para fora, revestido tudo de um pano de púrpura, também cuidadosamente pregado." (MarQues, 1971, p. 212)
} 
equivale a um ritual longo que começa com o 'falecido' ainda vivo e dura o tempo de aproximação da morte ${ }^{12}$. O corpo é colocado numa vala alongada, recoberta de terra. Autoflagelação e choros são comuns nesse momento. Essa vala é todos os dias regada, para que a carne entre mais rapidamente em decomposição. Depois de quinze dias, cava-se a vala novamente para a retirada das partes apodrecidas e lavagem dos ossos, que são, então, transferidos para o centro da aldeia, onde a cerimônia é iniciada. Os ossos são pintados de tinta vermelha, feita de urucum e, depois, colocados numa cesta, que é pendurada na cabana do morto. Dias depois, os familiares e um membro da tribo levam a cesta para a lagoa mais próxima, em cujo trecho de maior profundidade é fincada numa estaca.

Para os Yanomâmi, diferentemente, a pintura no rosto na cor cinza é o começo de tudo. Os homens enfeitam-se com araxina (enfeites de penas de arara, papagaio, cujubim e mutum) por meio de braçadeiras e brincos, com folhas de tabaco na arcada dentária e lábio inferior e com horoma-ép (penugem branca em flocos) nos cabelos.

Esses ritos não encerram toda a diversidade brasileira, mas permitem evidenciar o quão diferentes eram os rituais anteriormente ao período de chegada dos portugueses.

12 É interessante notar que é o próprio indivíduo que, ao se sentir adoentado, avisa aos companheiros para iniciar o ritual de colar com resina uma porção de penas brancas sobre todo o corpo doente, que vai tomando a aparência de uma grande ave. Cantos e lamentos acompanham essa tarefa. 


\subsubsection{Um quadro paulistano}

Atualmente, a cidade de São Paulo possui 40 cemitérios, dos quais 22 são públicos ${ }^{13}$ e 18 particulares ${ }^{14}$ (cf. Rezende, 2008), mas nem sempre foi assim.

O mais antigo cemitério paulistano, criado a céu aberto, ficava no que hoje conhecemos como bairro da Liberdade, muito próximo ao Largo da Forca, onde escravos ou outros indivíduos que tivessem pendências com as leis de então eram enforcados. Ao centro do terreno, ficava a Capela de Nossa Senhora dos Aflitos. ${ }^{15}$ Trata-se do Cemitério dos Aflitos (ou dos Enforcados), criado no final do século XVIII (1774, cf. JaVovitch, 1996).

Ali, enterravam-se indigentes, escravos e supliciados. Funcionou até 1856, quando já estava em curso a criação do

13 Cemitério do Araçá (1887), Cemitério do Campo Grande (1953), Cemitério da Consolação (1858), Cemitério Dom Bosco (1971), Cemitério da Freguesia do Ó (1908), Cemitério de Itaquera (1929), Cemitério de Lajeado (1903), Cemitério da Lapa (1918), Cemitério de Parelheiros (1956), Cemitério da Penha (1910), Cemitério da Quarta Parada (1893), Cemitério de Santana (1897), Cemitério de Santo Amaro (1856), Cemitério São Luís (1981), Cemitério São Paulo (1926), Cemitério São Pedro (1971), Cemitério da Saudade (1960), Cemitério do Tremembé (1937), Cemitério de Vila Formosa (1949), Cemitério de Vila Mariana (1904), Cemitério de Vila Nova Cachoeirinha (1968).

14 Cemitério de Colônia (1829), Cemitério Gethsêmani (s/d), Cemitério Israelita do Butantã (1953), Cemitério Israelita de Vila Mariana (1923), Cemitério da Ordem Terceira do Carmo (1862), Cemitério da Irmandade do Santíssimo Sacramento da Catedral de São Paulo (s/d), Cemitério dos Protestantes (1862), Cemitério do Redentor (1924), Cemitério de Congonhas (1969), Cemitério da Paz (1965), Cemitério do Morumbi (s/d), Cemitério Parque das Cerejeiras (1993), Cemitério Parque da Cantareira (s/d), Cemitério Parque dos Girassóis (s/d), Cemitério Parque Jaraguá (s/d), Cemitério Parque dos Pinheiros (1997).

15 A igreja dos Aflitos ainda se mantém entre a Rua dos Estudantes e a Rua da Glória, no bairro da Liberdade. 
Cemitério da Consolação, ${ }^{16}$ mas, somente em 1883, foi demolido. Dedicou-se uma parte do cemitério aos protestantes (a partir de 1862). As ossadas do cemitério, acredita-se, ainda estejam no mesmo lugar, embora o terreno tenha sido loteado e vendido a particulares como podemos notar, nas fotos a seguir, pelo seu entorno.

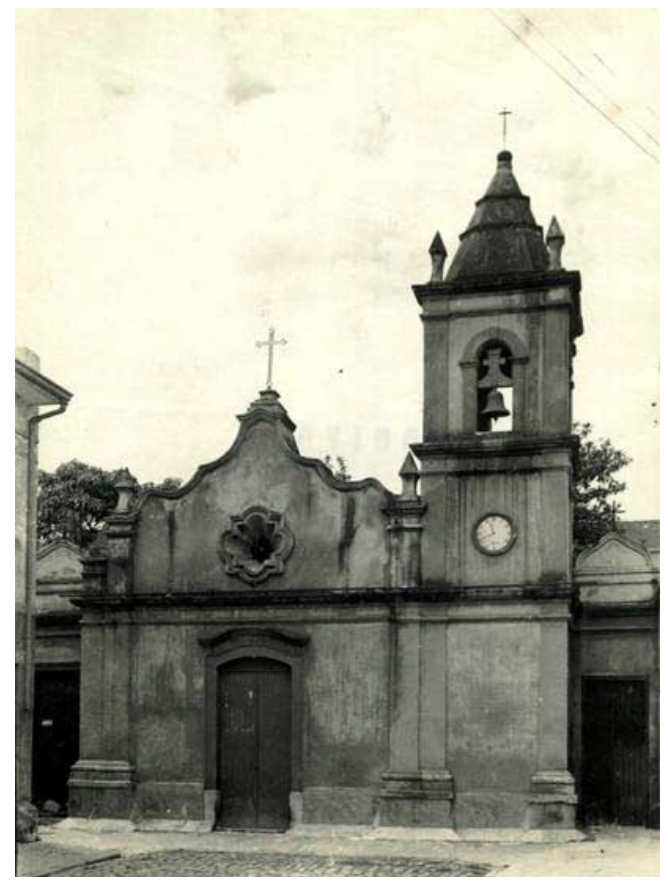

Antiga Capela de Nossa Senhora dos Aflitos (1939).

16 Marques (s/d, p. 179) apresenta informações conflitantes. Segundo ele, o cemitério da Consolação iniciou a construção em 1854 e foi aberto em 1858 em virtude da epidemia de varíola em São Paulo. 


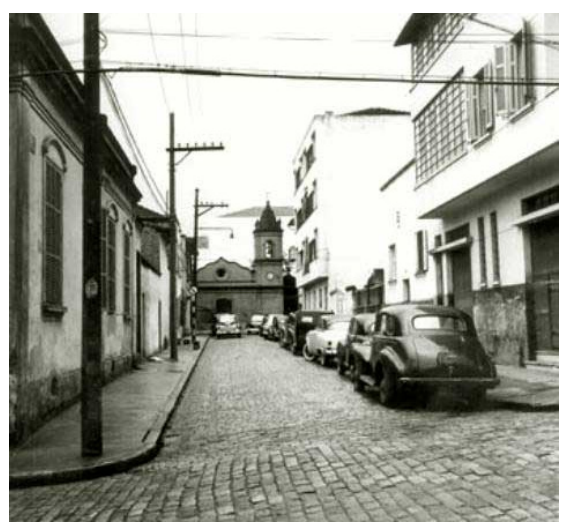

Rua dos Aflitos (1958). ${ }^{17}$

O Cemitério da Colônia (antigo Cemitério dos Alemães), situado até hoje em Parelheiros, foi o primeiro cemitério particular de São Paulo. Ele surgiu em decorrência da instalação de 200 imigrantes alemães não católicos na região Sul de São Paulo para trabalhar na colônia agrícola. No período da segunda Grande Guerra, permaneceu fechado, reabrindo somente mais recentemente (ano de 2000), depois de restaurado por uma associação de descendentes alemães.

17 Antiga Capela de Nossa Senhora dos Aflitos. Capela dos Aflitos, 1939 (photo20061105214016) e Rua dos Aflitos, 1958 (photo20070130154811) Fonte: [saudadesampa.nafoto.net]. Disponível em: http://www.girafamania.com.br/primitiva/cemiterios. htm>._Acesso em: 28 fev. 2014. 

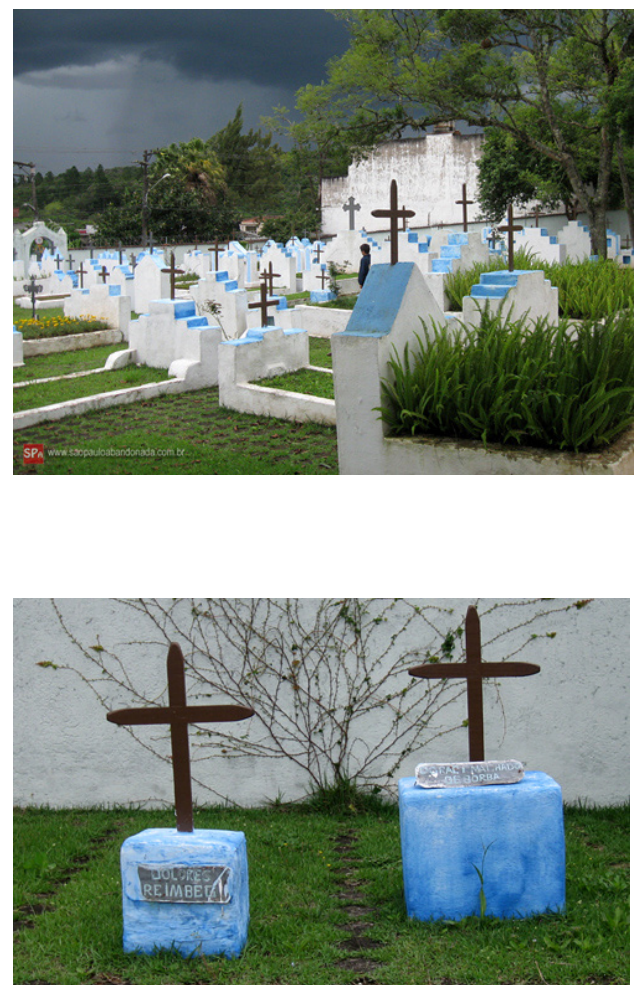

Cemitério da Colônia (Parelheiros). ${ }^{18}$

O cemitério de Santo Amaro foi inaugurado em 1856, uma solução à proibição régia de sepultamentos no interior de igrejas (Lei Régia de 01.10.1828). Hoje, é um cemitério público que atende a grande população, especialmente da zona Sul.

18 Disponível em: 〈http://www.saopauloantiga.com.br>. Acesso em: 28 fev. 2015. 

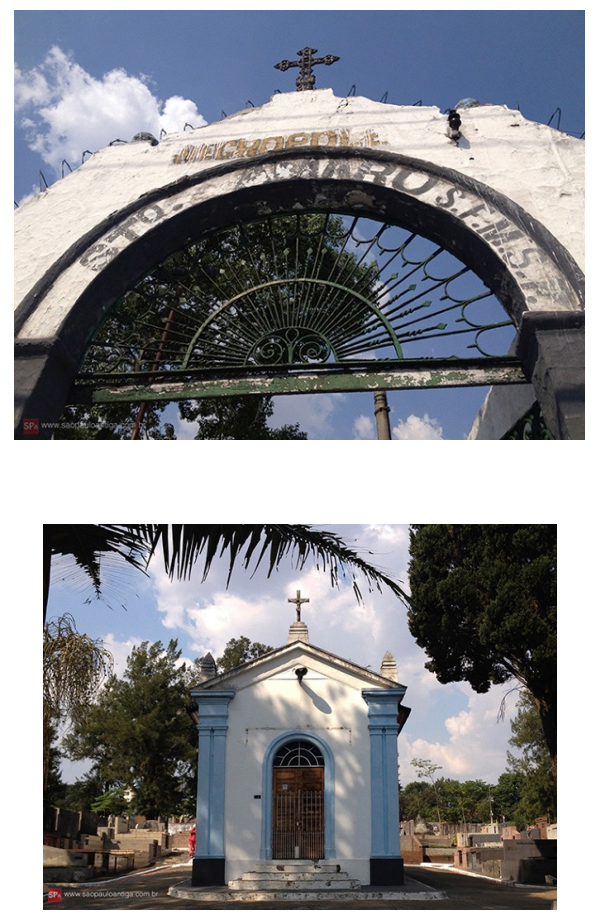

Cemitério de Santo Amaro. ${ }^{19}$

Ainda um outro cemitério esteve por anos contíguo ao Convento da Luz (desde 1845). ${ }^{20}$ Nele, seriam sepultadas religiosas e os capelães. Em 1851, metade do terreno foi cedido para um cemitério de estrangeiros católicos. Uma parte deste foi destinado aos estrangeiros não católicos, o que ficou conhecido à ocasião como o Cemitério dos Protestantes.

19 Disponível em: 〈http://www.saopauloantiga.com.br/cemiterio-de-santo-amaro/>. Acesso em: 28 fev. 2015.

20 Hoje é conhecido como Mosteiro da Luz. 

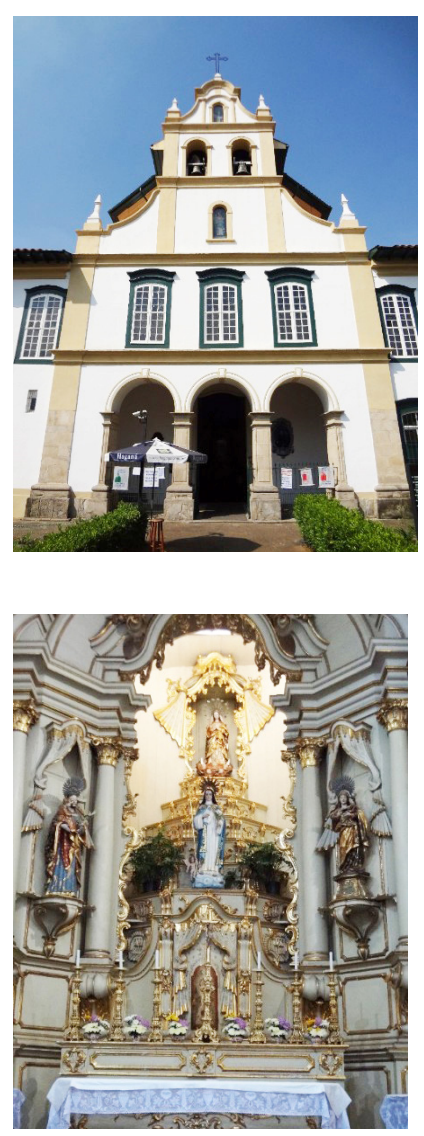

Mosteiro da Luz. ${ }^{21}$

Devido ao recorte metodológico que prioriza o cotejo de um desses cemitérios com outro de Macau, em momento oportuno trataremos do cemitério da Consolação, que teve uma função primordial na organização da cidade de São Paulo. Sua

21 Disponível em: 〈http://www.mosteirodaluz.org.br/category/galeria/fotos/>. Acesso em: 28 fev. 2015. 
fundação auxilia a compreender as razões para que uma área tão grande no centro de São Paulo fosse transformada em cemitério e, ao mesmo tempo, fornecerá informações igualmente importantes para o conhecimento da cultura dos habitantes do primeiro decênio do século XX. Antes, porém, visitaremos o espaço da China e de Macau.

\subsection{Tradição chinesa relativa à morte}

Tratar da China pressupõe lidar com uma extrema diversidade cultural. Se considerarmos, por exemplo, sua história milenar, sua diversidade (tecnicamente, são identificadas ao menos 56 etnias), sua dimensão geográfica, suas variadas tradições filosófico-religiosas (taoísmo, budismo, confucionismo, xamanismo), sua contemporaneidade política e tecnológica e seus contrastes (centros cada vez mais urbanos e espaços mais rurais ${ }^{22}$ ), seremos levados ao reconhecimento de um processo de variação e de mudança nos rituais fúnebres praticados no País do Meio. Assim é que oferecemos aqui um olhar mais genérico, mas adequado aos propósitos deste texto.

Esse espaço asiático prevê diferenças de tratamento ao morto a depender do nível social, estado civil e causas que motivaram a morte. Segundo essa concepção, e em função da profunda hierarquização entre gerações, os mais velhos não têm obrigações de respeito pelos mais jovens, o que faz com que o enterro de um mais jovem seja iniciado na casa funerária e não no lar, como aconteceria com os mais velhos. Nessa perspectiva,

22 Matéria do jornal Epoch Times, da China, revela esse contraste de atitudes ao relatar o caso de um idoso que, aos 92 anos, fugiu de casa para não ser cremado. Retornou à sua vila natal para ter direito a um sepultamento apropriado segundo sua concepção. 
os pais não fazem preces para os filhos e, como cabe aos filhos fazerem o ritual aos pais, os mais jovens ficam sem alguém que assuma essa função. É por isso que bebês e crianças não necessariamente têm rituais fúnebres. O silêncio é, salvo engano, a regra mais adotada nesses casos.

Assim como vimos com algumas tribos brasileiras, os preparativos para o funeral começam também antes mesmo que a morte ocorra:

Quando morre alguém na família, todas as estátuas dos deuses na casa são cobertas com um papel vermelho e retiram-se os espelhos do lugar. Acredita-se que se alguém vê o reflexo do caixão em um espelho, em um breve tempo haverá uma morte na própria família. Uma tela branca é colocada sobre a porta da casa e coloca-se um gongo à esquerda da entrada se o falecido for homem, e à direita se for mulher.

Antes de colocá-lo no caixão, se limpa o cadáver com uma toalha molhada, passa-se talco nele e veste-se com sua melhor roupa. Veste-se o corpo completamente, inclusive os sapatos, e faz-se a maquiagem se for mulher, porém nunca o vestem com roupas vermelhas (isso faria que ele se transformasse num fantasma). Em geral, se usam as cores preta, marrom ou azul. Antes de colocar o cadáver no caixão, cobre-se sua face com um pano amarelo e o corpo com um pano azul. (ЕРоcH Times, 2012) $)^{23,24}$

23 Atualizado em 11/09/2012 às 23h19. Acesso em: 28 fev. 2015.

24 Disponível em: https://www.epochtimes.com.br/funerais-tradicionais-chineses-um-ritual-profundo-trocado-pela-cremacao-2/\#.WcK7yNOGO-U Acesso em: 20 set. 2017. 
Também o lugar do velório dependerá do lugar em que a pessoa morreu. Caso a pessoa tenha morrido dentro de casa, o caixão permanecerá nesse local, mas, se a morte ocorreu fora, então o caixão deverá permanecer no jardim, em suportes e numa posição adequada ${ }^{25}$. É típico que haja comida para o falecido e que seu pente seja dividido em duas partes (uma vai para o caixão e outra, para a família). Não se pode usar joias ou vestidos vermelhos. Até hoje, os mais velhos impedem que os netos do falecido cortem o cabelo por 49 dias após o enterro e as cores das roupas também devem ser diferenciadas. ${ }^{26}$

Durante todo o velório, queimam-se incensos e papel "joss" (papel especial usado nesses rituais), e "dinheiro de oração" para prover ao falecido ingressos suficientes para a sua vida além-túmulo. Também é comum que as pessoas joguem jogos de azar durante o velório na casa do falecido, o que os faz distraírem-se da dor da perda.

Como no Ocidente, os rituais ligados à morte mantêm os simbolismos e a hierarquia da sociedade. Assim, a forma de ritualizar expressa a posição que ocupa o morto nas relações de poder. Como podemos depreender da imagem a seguir, enterrar os mortos em colinas também simboliza uma hierarquização. A construção em semicírculo, de forma paralela, representa a ideia de que o céu é redondo.

25 O caixão é posto sobre suportes a uns $30 \mathrm{~cm}$ de distância do solo, e a cabeça do caixão põe-se de frente para a parte interior da casa. As coroas, presentes e retratos ou fotos do falecido colocam-se na cabeceira do caixão. O caixão não é fechado durante o velório. 26 Crianças e noras vestem-se de preto, uma cor simbolizadora da angústia, e usam chapéus. Os netos vestem azul e os bisnetos azul claro. Genros utilizam cores mais chamativas e brilhantes, como o branco, por não integrarem o núcleo central da família. 


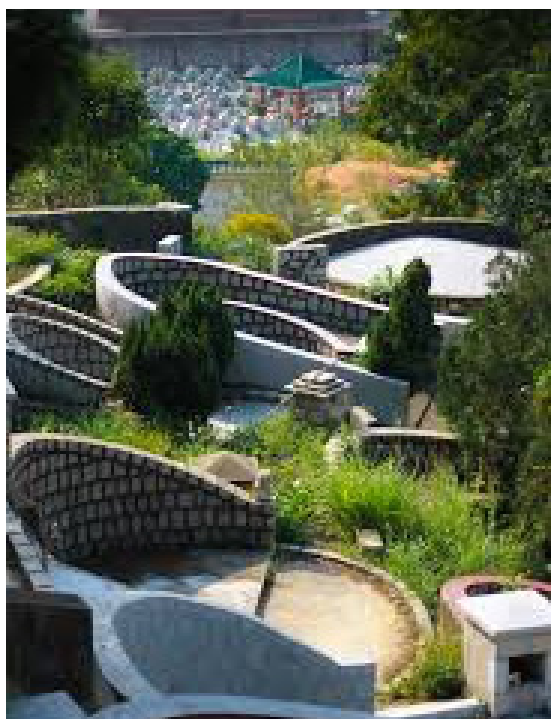

Cemitério Budista. ${ }^{27}$

Mais recentemente, grandes mudanças foram operadas nesses rituais. Nos centros urbanos e cada vez mais em regiões circunvizinhas a eles, os mortos têm sido cremados. O que surge desses rituais, não como uma constante ou um traço fixo chinês, mas como uma tendência bastante evidente, é uma relação familiar extremamente forte proveniente desse culto ancestral que se mantém no dia a dia de Macau, mesmo nas ruas, seja a partir do funeral, seja a partir dos sacrifícios. No caso do funeral, o milenar ritual de o morto levar os seus pertences ou, ao menos, ter a possibilidade de os ter na outra vida, continua também nas práticas cotidianas de queima de papéis.

27 Disponível em: <http://macauelogoali.blogspot.com.br/2011/12/cemiterio-budista. html>. Acesso em: 30 jun. 2015. 


\subsubsection{A morte entre os habitantes de Macau}

Macau, hoje conhecida como Região Administrativa Especial de Macau (RAEM), foi crescendo ao longo do século XX em direção às demais ilhas próximas, duas das quais incorporadas ao seu território (Coloane e Taipa). Nesse espaço geográfico, circulam, em grande maioria, chineses da China Continental, com hábitos e costumes diferentes, em grande medida, da população local de Macau, 'colonizada' por portugueses até 1999.

A chegada dos costumes católicos portugueses ocorreu no século XVI, gradativamente incluindo pessoas chinesas a esse campo de rituais. Um grupo especialmente citado é o dos macaenses, filhos da terra ${ }^{28}$.

Assim como há muito tempo há a escola, o cinema, o hospital, o bairro, a freguesia mais ou menos tipicamente chinesa, também, desde muito tempo, há o cemitério mais ou menos chinês. Os ritos funéreos, em Macau, realizam-se em 18 cemitérios $^{29}$. Todos eles são regidos pelo artigo $6^{\circ}$, Regulamento

28 Até bem recentemente, hoje cada vez menos, uma distinção entre macaenses, chineses e macaenses $100 \%$ era prioritária para o acesso aos serviços públicos diversos. Cada vez menos, há essa preocupação, que foi se alterando desde o handover, em 1999, quando a China retomou o poder sobre Macau.

29 Cemitérios públicos: Cemitério de S. Miguel Arcanjo (Península de Macau); Cemitério de Nossa Senhora da Piedade (Península de Macau); Cemitério do Carmo da Taipa (Ilha da Taipa); Cemitério Sá Kong da Taipa (Ilha da Taipa); Cemitério Municipal de Coloane (Ilha de Coloane); Cemitério Va Ian de Coloane (Ilha de Coloane). Disponível em: <http://www. iacm.gov.mo/p/facility/introduction/grave>. Acesso em: 20 set. 2017.

Cemitérios particulares: Cemitério Novo de Mong Há (Península de Macau), Cemitério dos Parses (Península de Macau), Cemitério Protestante (Península de Macau), Cemitério da Mesquita (Península de Macau), Cemitério Kai Fong (Ilha da Taipa), Cemitério Hao Si (Ilha da Taipa), Cemitério Pao Choc (Ilha da Taipa), Cemitério Ka Ho (Ilha de Coloane), Cemitério Son I (Ilha de Coloane), Cemitério Kok Ip (Ilha de Coloane) e Cemitério Hac Sa (Ilha de Coloane). Disponível em: <http://bo.io.gov.mo/bo/i/2003/47/regadm37.asp?mobi- 
Administrativo $\mathrm{n}^{\circ} 37 / 2003$, que orienta o respeito e a tranquilidade nos cemitérios. ${ }^{30}$

Um dos cemitérios mais visitados em Macau é o Protestante, justamente por estar em um espaço privilegiado de turismo, no bairro Santo Antônio:
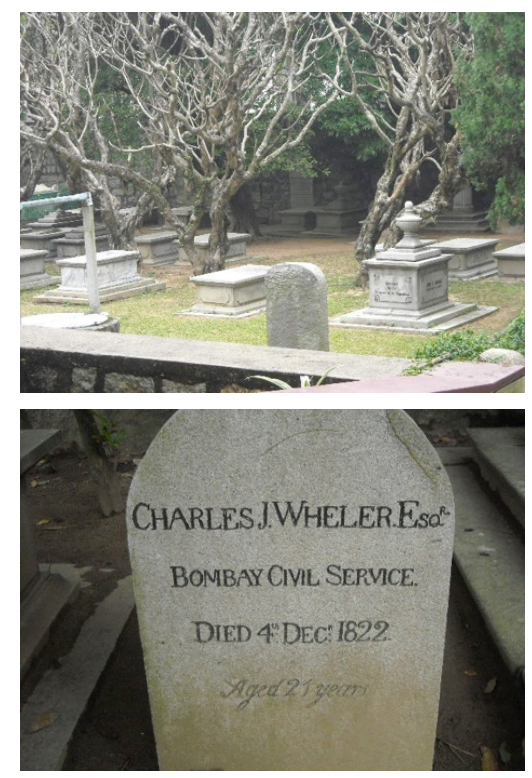

Cemitério Protestante. ${ }^{31}$

le=1>. Acesso em: 20 set. 2017. Há, ainda, o United Chinese Cemetery (o Cemitério Budista). 30 "1. Nos cemitérios é proibido: 1) Proferir palavras ou praticar actos adequados a impedir ou perturbar, ainda que sem ameaça, o exercício do culto de religião, bem como a realização de cerimónia fúnebre; 2) Proferir palavras ou praticar actos adequados a ofender o sentimento de reverência dos vivos para com os mortos; 3) Fazer publicidade comercial ou exercer a venda ambulante; 4) Exercer a mendicidade.

2. Depende de autorização prévia da entidade gestora do cemitério, a captação de fotografias e a realização de filmagens que tenham finalidades comerciais, bem como reportagens dentro do cemitério." Disponível em: <http://bo.io.gov.mo/bo/i/2003/47/ regadm37.asp?mobile=1>. Acesso em: 20 set. 2017.

31 Arquivo pessoal, fotografia de 2010. 
Esses cemitérios seguem uma estética diversa a depender do grau de entrosamento com a sociedade portuguesa da Macau 'colonial', mas uma coisa é certa: cada vez mais, os habitantes chineses de Macau foram aderindo ao féretro (e a outros rituais) ocidental durante o século XX por razões diversas. Isso justifica por que não se veem símbolos católicos, como harpas, anjos e cruzes no cemitério Protestante, tão apartado da cultura predominante local no século XX.

Podemos dizer que o Cemitério São Miguel Arcanjo, um cemitério público encrustado entre o bairro de São Lázaro e o Centro, é um cemitério tipicamente macaense. Ao longo do século XX, foi incorporando a nata da sociedade e, depois, outros tantos habitantes em seus estreitos espaços.

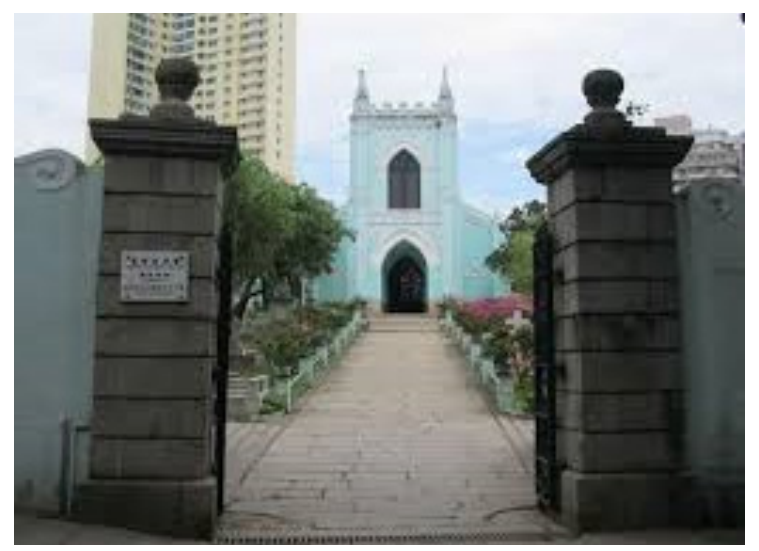

Cemitério de S. Miguel Arcanjo. ${ }^{32}$

32 Disponível em: <http://www.iacm.gov.mo/p/facility/introduction/grave>. Acesso em: 30 jun. 2015. 
Outros cemitérios marcam a multiculturalidade, a multifiliação filosófico-religiosa, como o Cemitério dos Parses (Península de Macau), o Cemitério da Mesquita (Península de Macau) e o conhecido Cemitério Budista (Ilha de Taipa).

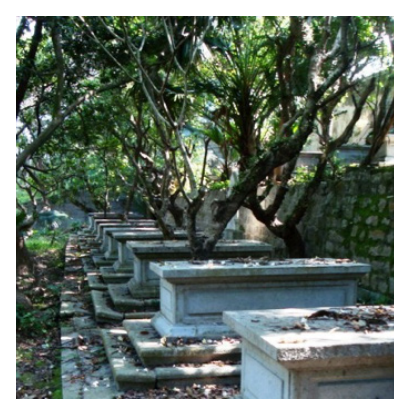

Cemitério dos Parses ${ }^{33}$

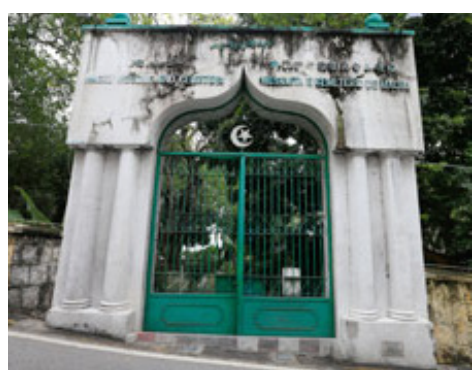

Cemitério da Mesquita ${ }^{34}$

33 Disponível em: <http://macauantigo.blogspot.com.br/2014/02/cemiterio-dos-parses. html>. Acesso em: 30 jun. 2015.

34 Disponível em: <http://pt.macaotourism.gov.mo/sightseeing/sightseeing_detail. php?c=8\&id=315\#.WoQjF0xFy71>. Acesso em: 30 jun. 2015. 


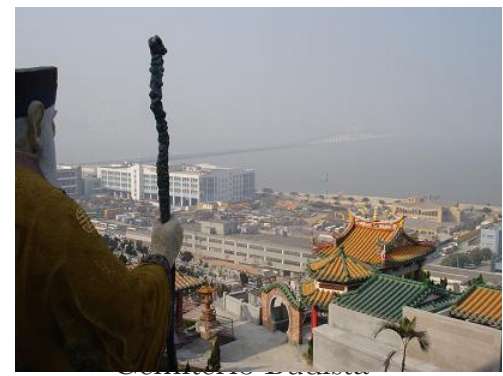

A presença de diversos grupos étnicos em Macau, muitas vezes com presença social muito discreta, fica marcada pelos cemitérios. Como podemos ler no site da Direç̧ão dos Serviços de Turismo de Macau a respeito do Cemitério da Mesquita (Península de Macau), "As sepulturas, algumas das quais com mais de cem anos, atestam uma vez mais a tolerância multicultural de Macau, ao longo dos séculos, e servem de prova histórica da ligação islâmica ao território" ${ }^{36}$.

Como um espaço multiétnico que herda culturas de povos asiáticos e não asiáticos milenares, diferentes rituais de morte também têm lugar em Macau. Os cemitérios, entretanto, como espaços de rituais fúnebres, são espaços privilegiados que espelham toda essa diversidade cultural.

35 Disponível em: <http://www.itravelnet.com/photography/asia/macau/taipa/united-chinese-cemetery.html>. Acesso em: 30 jun. 2015.

36 Disponível em: <http://pt.macautourism.gov.mo/sightseeing/sightseeing_detail.php?c=8\&id=315\#.VZLgYxNViko>. Acesso em: 30 jun. 2015. 


\section{Viver é se manter vivo na memória}

Philippe Ariès (2003) afirmou, em algum momento de sua produção, que a morte foi banida das preocupações do homem ocidental do século XX, razão pela qual acabou por ser marginalizada. Essa marginalização teve como consequência a criação de um tabu em torno do tema e também a terceirização das relações com a morte (cf. Consorte, 1983; QueIroz JR., 1983; Santos, 1983).

Uma das trajetórias da morte, no Ocidente, tem início com sua aceitação na Idade Média, quando todo o ritual era socializado, e a despreocupação com o destino do corpo era ge$\mathrm{ral}^{37}$. Com o século XII, o 'mundo pleno' da Europa Medieval, as mudanças já estão agindo, lentamente, no sentido de que a morte passe a ser vista com maior dramaticidade, individualidade: as sepulturas vão se tornando individualizadas, identificadas, dentro das igrejas ou em capelas mortuárias ${ }^{38}$. O homem vai

37 Segundo os autores consultados, os corpos eram enterrados, na mesma vala, algumas vezes no interior da igreja, outras vezes em volta desta, sem o cuidado de identificação pessoal.

38 Segundo informações extraídas no site da Assembleia Legislativade São Paulo, que, por sua vez, recolheu em Antônio Egydio Martins, o serviço de enterramento dentro das igrejas era realmente dramático: "O serviço de enterramento de cadáveres nas igrejas ou nos cemitérios contíguos às mesmas era feito, antigamente, por pretos africanos, que, à proporção que iam pondo terra sobre o cadáver, socavam este com uma grossa mão-de-pilão, contando o seguinte: Zóio que tanto vê. Zi boca que tanto fala. Zi boca que tanto zi comeu e zi bebeu. Zi cropo que tanto trabaiô. Zi perna que tanto andô. Zi pé que tanto zi pisô. E assim iam eles cantando esses e outros despropósitos até acabarem de cobrir com terra a sepultura, sendo que, em conseqüência de quase todas as irmandades possuírem um só caixão, o cadáver de qualquer dos seus irmãos era sepultado sem o mesmo caixão, voltando este, depois de enterrado o cadáver, para a sacristia da igreja, na qual ficava guardado até o dia em que novamente era pedido para servir a algum irmão falecido de uma daquelas irmandades. Os moradores das proximidades das mesmas igre- 
descobrindo a "morte de si mesmo" e esta adquire características eróticas e de morbidez.

Com o século das Luzes e do Barroco, a morte começa a ser dramatizada, exaltada. Toma sentido a "morte do outro", e a morte assume o significado de ruptura, passa a ser indesejável, embora admirada pela beleza que lhe dá o romantismo. A morte do século XIX é acompanhada no leito moribundo, por ritos e manifestações de choros, gestos dramáticos, uma afetividade macabra, que Ariés explica pela religião emotiva do catolicismo romântico ou do pietismo protestante ${ }^{39}$. "Surge o culto contemporâneo com túmulos individuais ou familiares, da sepultura como propriedade particular e perpétua e o culto da saudade, com as periódicas peregrinações aos cemitérios" (MARCílio, 1983, p. 63). É a morte suscitando vida.

Segundo Marcílio (1983), a civilização urbana e industrial altera o quadro funerário. Mais especificamente a partir de 1950, não se morre mais em casa, mas no hospital. A morte é algo escondido, as pessoas são desenganadas, os médicos se

jas e cemitérios, por causa de tais cantigas e socamentos de cadáveres, ficavam bastante amedrontados com isso, ouvindo, a alta hora da noite, naqueles lugares, certo rumor que lhes parecia estarem cantando e socando, tratando, logo que podiam, de mudar dos mesmos lugares para outros pontos da Cidade mais distantes das igrejas e cemitérios." [sic]. 39 "No período colonial foi escassa a presença de protestantes no Brasil. Somente no início do século 19, após a transferência da corte portuguesa para o Rio de Janeiro, o protestantismo começou a inserir-se de modo mais amplo na sociedade brasileira. Essa inserção teve duas fases bem definidas. Inicialmente, a partir de 1810, houve o surgimento do chamado 'protestantismo de imigração', ou seja, todos os protestantes existentes no Brasil eram estrangeiros que para cá tinham vindo como imigrantes, especialmente ingleses (anglicanos) e alemães (luteranos). Posteriormente, surgiu o 'protestantismo de missão', como resultado do trabalho de missões européias e norte-americanas entre os brasileiros. Essa modalidade implantou-se definitivamente a partir de 1855, com a chegada do Rev. Robert Reid Kalley, seguido, em 1859, pelo Rev. Ashbel Green Simonton.” (Matos, s/d, s/p.) 
calam diante do processo de chegada da morte ${ }^{40}$, os familiares fazem o mesmo. A partir desse período, as manifestações que tornem presente a morte ocorrida são condenadas e, por isso, vão caindo em desuso na sociedade. Surge com força a incineração ou cremação, muito mais adotada pela camada de elite e, depois, pelos populares.

Não se deve perder de vista que, com a cremação, desaparecem os restos mortais que não serão mais cultuados em cemitérios, e toma seu lugar o ritual de espalhar as cinzas, que se dispersam. Nessa dispersão, simboliza-se a dissipação da dor da perda, o minimizamento do sofrimento. E a morte, como no ritual anterior, representa a eternização da vida, pois servirá de adubo ou de alimento a outra vida, e a vida ressurgirá em vida, numa outra vida. E a metáfora se faz.

\subsection{A construção da memória e da saudade}

Outro elemento que compõe o cenário como espelho é a língua, em suas modalidades falada e escrita, a qual se presta como espaço de vazão das sensações humanas diante da morte. Essa vazão se mostra em ditos populares, em frases feitas de condolências, e especialmente em epitáfios.

Uma expressão italiana de alta recorrência diz que, para receber elogios, o melhor meio é morrer. Esse dito revela muito sobre o comportamento das pessoas diante da morte. As últimas

\footnotetext{
40 De acordo com Jacques Ruffié (1988, p. 216), o médico enfrenta a morte de seus pacientes de um modo diferente: "Primeiro existe a morte do outro, do doente. Eu a vivi, acabrunhado, como médico, sem jamais aceitá-la (sic), sobretudo nos jovens, no estudante que não voltará ao colégio, na mãe que vai deixar os seus filhos, no pai que já não sustentará o lar. Pode acontecer que sintamos esses falecimentos prematuros como uma injustiça revoltante, e que meçamos por eles toda a precariedade da vida."
} 
palavras que ficam sobre o morto, invariavelmente num epitáfio, garantem que não há um único traço de maldade ou de ressentimento que envolva os mortos. Se os mortos pudessem ler os epitáfios que seus herdeiros lhes consagram, achariam que entraram no cemitério errado.

Os epitáfios fazem com que as mensagens sejam marcas de saudades e de profunda lacuna que se abre como uma ferida entre os membros de uma família. No entanto, quando redigidos pelos próprios futuros mortos, ganham em lirismo. É o que lemos nos epitáfios elaborados por célebres autores, como João Cabral de Melo Neto ${ }^{41}$, Charles Baudelaire ${ }^{42}$, André Malraux ${ }^{43}$ e Oswald de Andrade ${ }^{44}$.

\subsubsection{Por meio de epitáfios: homenagens e sentimentos ecoados}

A história dos epitáfios e das inscrições tumulares entrecruza-se quanto a soluções familiares encontradas. É raro que o próprio morto tenha pensado em deixar algo para ser colocado

41 Nesta terra ninguém jaz, | pois também não jaz um rio | noutro rio nem o mar | é cemitério de rios $\mid$ Nenhum dos mortos daqui $\mid$ vem vestido de caixão. |Portanto, eles não se enterram | são derramados no chão.|| Vêm em rêdes (sic) de varandas | abertas ao sol e à chuva.|Trazem suas próprias moscas.| O chão lhes vai como luva.|| Morto ao ar-livre, que eram, | hoje à terra livre estão. | São tão de terra que a terra $\mid$ nem sente sua intrusão. João Cabral de Melo Neto (1965, p. 128).

42 Ó Morte, velho capitão, é tempo! Às velas! | Este país enfara, ó Morte! Para a frente!| Se o mar e o céu recobre o luto das procelas, | Em nossos corações brilha uma chama ardente! (Charles Baudelaire, In: Le voyage).

43 A morte transforma uma vida em destino. Malraux-

44 Eu sou redondo, redondo $\mid$ Redondo, redondo eu sei $\mid$ Eu sou uma redond'ilha $\mid$ Das mulheres que beijei.

Vou falecer do Oh! Amor $\mid$ Das mulheres de minh'ilha $\mid$ Minha caveira rirá ah!ah!ah!| Pensando na redondilha (Oswald de Andrade, 1976) 
em seu túmulo. A família é quem decide o que fica exposto, às vezes elaborando algo criativo e totalmente personalizado ao indivíduo que morreu, motivado pelo sofrimento vivenciado com a perda. Desde o início do século XX até meados desse mesmo século, escolhia-se entre frases prontas aquilo que melhor agradava à familia do morto. Mais recentemente ainda, nada se inscreve. A morte tornou-se efetivamente o silêncio familiar, o luto verbal.

A palavra epitáfio ${ }^{45}$, do grego epitáphion, entrou no português pela língua latina (epitaphiu), um substantivo masculino que remete a quatro acepções: 1. Inscrição tumular; 2. Por extensão, lápide ou tabuleta com epitáfio; 3. Elogio fúnebre; 4. Espécie de poesia satírica (em geral uma quadra) feita sobre um vivo como se se tratasse de um morto (Holanda, 1999, p.780). Vejamos alguns epitáfios:

Aqui jaz hum que em outro tempo foi grande varom Sabedor e muito eloquente e avondado e rico e agor He pequena cinza encarrada em este moimento E com el jaz hum seu sobrinho dos quaes hum Era já velho e o outro mancebo e o nome do Tio Sesnando e Pedro avia nome o Sobrinho (Epitáfio do Conde D.Sesnando, apud LeOni, 1858) ${ }^{46}$

45 De acordo com a Encyclopaedia Britannica (1768, p. 661-662), as mais antigas inscrições tumulares, escritas, são dos antigos egípcios em sarcófagos e caixões. Em Esparta, os epitáfios eram destinados a herois de guerra, em Atenas, a todos indiscriminadamente. No Museu Britânico, há inscrições de várias urnas, com pouca variação.

46 "Ainda que na lingua vulgar se não empreguem hoje todas as formas da construcção latina, não é, todavia, possivel deixar de reconhecer essas formas em nossas antigas escripturas, onde apparece a mais completa analogia de syntaxe. - Para prova citaremos o Epitaphio do Conde D. Sesnando, que se conserva 'numa das paredes de Sé Velha de 
Os epitáfios ${ }^{47}$, que são as inscrições tumulares, ocupam um papel antigo na história do homem, sendo as mais antigas localizadas nos sarcófagos e caixões egípcios. As já decifradas continham todas a mesma forma: começavam por uma reza dedicada a uma divindade e depois ao nome e função do falecido na sociedade (cf. Encyclopaedia BRITANNICA, 1768, p. 661-662). Nos dois cemitérios selecionados para esse levantamento, um em São Paulo (Cemitério da Consolação) e outro na RAEM (São Miguel de Arcanjo), encontramos epitáfios com características similares, o que nos conduz à ideia de uma interferência cultural portuguesa, pois distanciam-se dos costumes locais anteriores à chegada portuguesa. Vejamos os quatro padrões que identificamos:

a) epitáfios como simulacro da fala do morto

Eu vou para Deus. Mas não| esquecerei aqueles a quem | amei na terra. |Sto. Agostinho | Eterna saudade da sua | esposa, filhos e família | À saudosa memória | de| Luís Braga | Nasceu em 02-07-48 | Faleceu em 14-01-84 (Cemitério de S.Miguel Arcanjo - Macau)

Coimbra, e que mostrando pela construcção ser trasladado de outro escripto em latim, está, comtudo, no estilo e gosto de nossa antiga linguagem. J. Pedro Ribeiro, ao passo que não duvida da procedencia latina d'esta inscripção, confessa com bastante ingenuidade para um partidario do systema celtico, que pela phrase indica ser do tempo de D.João $1^{\circ}$ até D.Manuel. Vid. Dessert. Chron. T. 1º p. 193, nota.”' (Leoni, 1858).

47 Em cada cultura, o epitáfio se presta a um fim específico. Na Esparta, eram destinados a heróis de guerra somente; em Atenas, tinham uso geral; em Roma, registravam fatos importantes, ao contrário do que ocorria na Grécia Antiga. 
José Tavares | de Miranda | 16-11-1916. + 20-08-1992 | "Maior do que a lua, | do que o sol e as | outras estrelas é o | lampião que alumia | a esquina da rua | onde nasci.” (J.T.M.) (Cemitério da Consolação - São Paulo)

b) epitáfios como síntese de vida e dos feitos

Aqui jaz | Francisco Antonio Fernandes | Natural de Chander de Salsete - Gôa | Cavalleiro da antiga ordem de Torre e Espada| Nasceu aos 4 d'outubro de 1818| Falleceu n'esta cidade aos 20 de março de 1882| R.I.P. | (Cemitério de S.Miguel Arcanjo)

Viveu, sofreu e morreu | amando Jesus. | 19-10-1918. +21-12-1930 (Cemitério da Consolação)

c) epitáfios como mensagens de saudades na voz de familiares

Esta lousa | encobre as cinzas | d'uma mulher virtuoza e| d'uma may carinhosa|Emilia Maria | D'Encarnação e Silva | nasceo aos 17 de mayo de | 1820| E voou para o eterno | em 27 do mesmo mez do anno | de 1864 |É dos sentidos filhos | esta homenagem (Cemitério de S.Miguel Arcanjo)

Ao adorado Álvaro. | Meu inesquecível filho, carinhoso e | santo. | Faz dois annos que morreste, filho. | Dois longos annos sem jamais te ver! | Filho querido, que deixaste o mundo, I e os meus carinhos, para aqui jazer! | Oh! Tu deixaste tua mãe tão cedo! | Trocaste a vida pelo frio chão. | Eu só queria que pudesse ainda 
| cingir-te, filho, junto ao coração! | Eu só queria que pudesse, filho, | voar alegre para a eternidade, | e lá risonha, como branca estrella, | seguir-te comtigo pela immensidade! | 25-09-1921. | Tua desventurada mãe, de $\mid$ eterna saudade pungida. (Cemitério da Consolação)

\subsubsection{Esculturas: emoções e sentimentos pela arte}

Nos dois cemitérios públicos que selecionamos para estudo neste texto, identificamos outra forma de escoar os sentimentos e emoções que envolvem toda a família e os visitantes dos cemitérios nesse sentimento de esquiva da morte: as esculturas. Tanto no Brasil quanto na RAEM, as formas de manifestação da arte são muito parecidas, e os símbolos utilizados para manifestar a saudade e a homenagem são derivados da interpenetração da cultura 'colonial'.

\subsubsection{A cruz}

Entre os cristãos, a cruz tem um significado forte e redentor. Durante o século XX, todo católico carregava consigo uma corrente (ou cordão) ao pescoço com esse símbolo pendurado. As freiras, invariavelmente, usam um anel em que uma cruz está impressa, marcando a entrega de sua vida aos propósitos de Jesus.

Historicamente, a crucificação era uma forma romana de punição e de tortura a pessoas que fugiam de algum modo às leis romanas. Jesus Cristo, filho de Deus para os católicos (os cristãos), foi crucificado e desse advento surge metonimicamente o espaço do martírio como o símbolo que une os cristãos. 


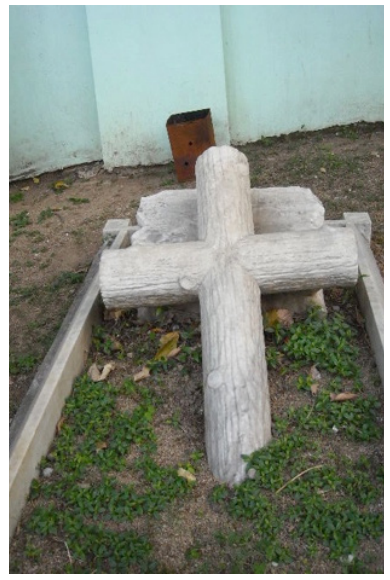

Cemitério S. Miguel Arcanjo. ${ }^{48}$

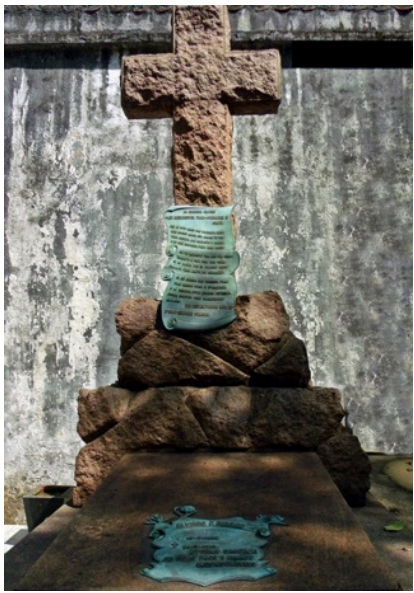

Cemitério da Consolação. ${ }^{49}$

48 Arquivo pessoal. Registro em 2010.

49 Arquivo pessoal. Registro em 2010. 
Muitas são as expressões que incorporam os valores semânticos da cruz para construir outras expressões cristalizadas na língua. Vejamos algumas delas:

Quadro I: Síntese de usos e equivalências - cruzes

\begin{tabular}{|c|c|}
\hline Expressão & Sentido equivalente \\
\hline $\begin{array}{c}\text { Estar entre a cruz e a } \\
\text { espada }\end{array}$ & sentir-se em dúvida entre duas coisas importantes \\
\hline $\begin{array}{c}\text { Estar entre a cruz e a } \\
\text { caldeirinha }\end{array}$ & sentir-se em dúvida entre duas coisas importantes \\
\hline Carregar uma cruz & Fazer o serviço pesado ou tarefas mais difíceis \\
\hline Levar a cruz ao calvário & Esforçar-se por concluir uma ação difícil \\
\hline Fulano é minha cruz & Ser um peso demasiado na vida de outra pessoa \\
\hline Cruz credo! & Interjeição que significa repúdio \\
\hline
\end{tabular}

\subsubsection{Anjos celestiais}

Anjos simbolizam um ser puramente espiritual (cristianismo, judaísmo e islamismo), e essa pureza invariavelmente é associada às crianças (inocência) e às moças (virgindade). 


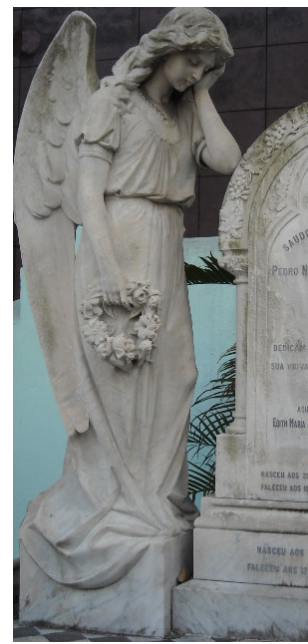

Cemitério S.Miguel Arcanjo. ${ }^{50}$

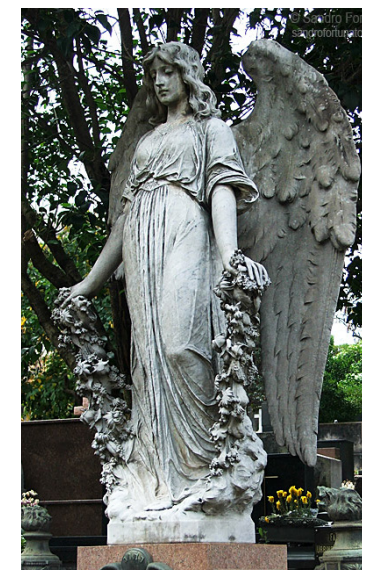

Cemitério da Consolação. ${ }^{51}$

50 Arquivo pessoal. Registro em 2010.

51 Arquivo pessoal. Registro em 2010. 
Quadro 1I: Usos e equivalências - Anjos

\begin{tabular}{|c|c|}
\hline Expressão & Sentido equivalente \\
\hline Ser um anjo & Ser bom, ser gentil, auxiliar \\
\hline Ser um anjinho & Não ser travesso \\
\hline Anjo da guarda & Protetor, segurança \\
\hline Dormir como um anjo & Dormir profunda e tranquilamente \\
\hline Cantar como um anjo & Cantar afinadamente \\
\hline
\end{tabular}

\subsubsection{Mulheres em sofrimento/desolação}

As mulheres são as que geram uma nova vida em qualquer sociedade, pelo menos numa perspectiva mais tradicional. Homens e mulheres, salvo engano, são seres que experienciam o sofrimento ao longo da vida e, como efeito, da perda por morte.

Nos cemitérios, no entanto, é bastante incomum encontrar imagens masculinas conotando desolação e sofrimento. Homens enfrentam a morte com força e coragem, pelo menos é o que os semblantes em esculturas de cemitérios nos permitem ler. Mulheres representam melhor o sofrimento sem fim, a desolação e o luto. Na maioria das culturas, há alguma diferença entre a mulher que perde o marido e a mulher que perde qualquer outro parente da família. Também há diferença entre a mulher que perde o marido e o marido que perde a mulher. As mulheres culturalmente marcam essa passagem na vida com roupas, costumes e hábitos diferentes, talvez por isso sejam as imagens perfeitas para a marca do sofrimento nas estátuas dos cemitérios que visitamos. 


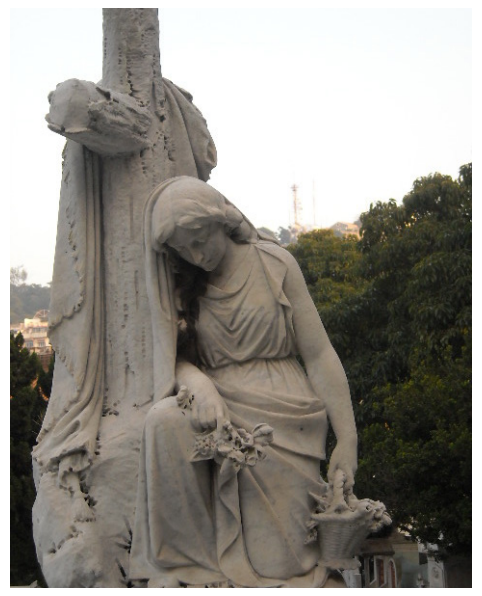

Cemitério S.Miguel Arcanjo. ${ }^{52}$

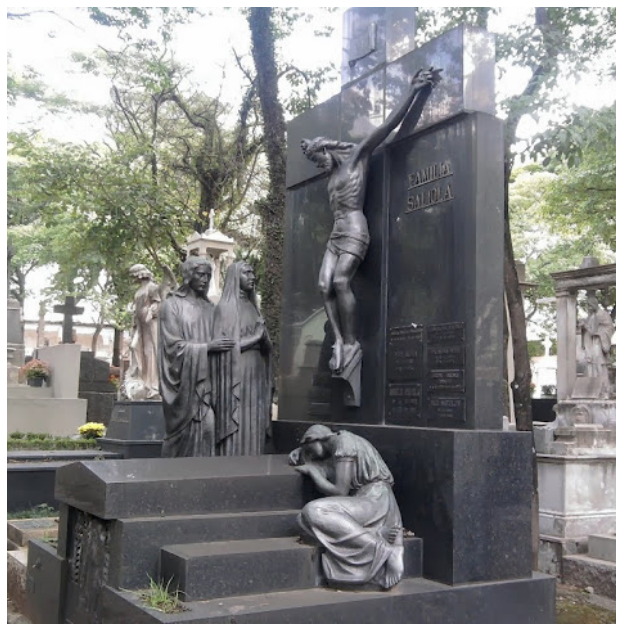

Cemitério da Consolação. ${ }^{53}$

52 Arquivo pessoal. Registro em 2010.

53 Arquivo pessoal. Registro em 2010. 


\section{Considerações finais}

Investigar a morte é uma forma de entender como, historicamente ou sincronicamente, os homens têm criado as relações de poder na sociedade e as cristalizado em suas culturas. O que quisemos apontar aqui foi, além disso, o fato de que a morte em ambientes tão distantes geográfica e culturalmente acaba sendo ritualizada de uma forma semelhante. Base para essa constatação é não apenas a relação contraditória que muitas sociedades têm com esse aspecto da vida, mas sobretudo a perspectiva de que a viagem portuguesa pelo mundo criou, de certa forma, essas aproximações que duram no tempo e no espaço.

Aproximar Macau e São Paulo, dois contextos tão diversos, termina por abrir espaço para fazer outras aproximações. Não no sentido do apagamento, mas no sentido da busca de diferentes formas de viver uma herança cultural, como a que praticamos aqui e acolá para ritualizar a morte e ritualizar a vida.

\section{Referências}

Andrade, Oswald de. Poesias reunidas. São Paulo: Círculo do livro, 1976. p. 197.

ARIÈs, Philippe. História da morte no Ocidente. Rio de Janeiro:

Ediouro, 2003.

Baudelaire, Charles. As flores do mal. Tradução de Ivan Junqueira. Rio de Janeiro: Nova Fronteira, 1985.

Braet, Herman; Verbeke, Werner (Ed.). A morte na Idade Média. Tradução de Heitor Megale, Yara Frateschi, Maria Clara Cescato. São Paulo: Edusp, 1996. 
Benedict, Ruth. Padrões de cultura. Lisboa: Livros do Brasil, s/d. Bertolli Filho, Gláudio; Meiny, José Carlos Sebe Bom. Morte e sociedade em Lima Barreto. In: Martins, José de Souza (Org.). A morte e os mortos na sociedade brasileira. São Paulo: Hucitec, 1983. p. 142-169.

Consorte, Josildeth. A morte na prática médica. In: MARTins, José de Souza (Org.). A morte e os mortos na sociedade brasileira. São Paulo: Hucitec, 1983. p. 38-57.

Enclyclopaedia Britannica: a new survey of Universal Knowledge. Vol. 8. Chicago, London, Toronto, Encyclopædia Britannica, Inc., 1768.

Fontes, Ofélia. O indio brasileirinho. Rio de Janeiro: Primor, 1976.

Holanda, Aurélio Buarque de. Novo Aurélio Século XXI: o dicionário da língua portuguesa. Rio de Janeiro: Nova Fronteira, 1999.

Javovitch, Paula. Além muros. Revista Cidade, n. 4, p. 126-129, 1996. Disponível em: https://versaopaulo.wordpress.com/2013/11/18/alem-muros/. Acesso em: 20 set. 2017.

Leoni, Francisco Evaristo. Genio da Lingua Portugueza, ou causas racionaes e philologicas de todas as formas e derivações da mesma lingua, commprovadas com innumeraveis exemplos extrahidos dos auctores latinos e vulgares. Tomo I. Lisboa: Typographia do Panorama, 1858.

Magalhães, Ana Paula Tavares de. Resenha de $A$ morte na idade média. Revista de História, São Paulo, n. 137, p. 145-149, 1997. Disponível em: www.revistas.usp.br/revhistoria/article/ view/64540 Acesso em: 20 set. 2017. 
Malraux, André. Romans: Les conquérants. La condition humaine. L'espoir. Gallimard, 1952. Disponível em: <http://www. frasesdepensadores.com.br/frase/morte-transforma-vida-em-destino/>. Acesso em: 20 set. 2017.

Marcílio, Maria Luiza. A morte de nossos ancestrais. In: Martins, José de Souza (org:). A morte e os mortos na sociedade brasileira. São Paulo: Hucitec, 1983. p. 61-75.

Marques, António Henrique Rodrigo de Oliveira. A sociedade medieval portuguesa: aspectos da vida cotidiana. Lisboa: Sá da Costa, 1971.

Marques, Manuel Eufrásio de Azevedo. Apontamentos históricos, geográficos, biográficos, estatísticos e noticiosos da Província de São Paulo seguidos da Cronologia dos acontecimentos mais notáveis desde a fundação da Capitania de São Vicente até o ano de 1876. Publicações comemorativas sob o alto patrocínio da Comissão do IV Centenário da Cidade de São Paulo. São Paulo: Biblioteca Histórica Paulista, s/d.

Martins, José de Souza. História e Arte no Cemitério da Consolação. Folder para visitação pública da Prefeitura da Cidade de São Paulo. s/d.

Matos, Alderi Souza de. O cemitério dos protestantes de São Paulo. Disponível em: <http://www.mackenzie.br/10221.html>. Acesso em: 23 fev. 2015.

Melo Neto, João Cabral de. Antologia poética. Rio de Janeiro: Editora do Autor, 1965.

Queiroz JR., Teófilo de. Dos mortos e sua volta. In: Martins, José de Souza (Org.). A morte e os mortos na sociedade brasileira. 
São Paulo: Hucitec, 1983. p. 103-112.

Rezende, Eduardo Coelho Morgado. O enigma dos cemitérios da cidade de São Paulo. In: Rezende, Eduardo Coelho Morgado; FErreira, Ricardo Vicente (org.). A Geografia fora da sala de aula. São Paulo: Necrópolis, 2008. p. 99-109.

Ribeiro, Marily Simões. Arqueologia das práticas mortuárias. São Paulo: Alameda, 2007.

Rodrigues, José Carlos. O corpo na história. Rio de Janeiro: Fiocruz, 1999.

Ruffié, Jacques. O sexo e a morte. Tradução de Carlota Gomes. Rio de Janeiro: Nova Fronteira, 1988.

Santos, Célia Almeida Ferreira. Os profissionais de saúde enfrentam-negam a morte. In: Martins, José de Souza (Org.). A morte e os mortos na sociedade brasileira. São Paulo: Hucitec, 1983. p. 15-24.

Silva, Da Costa e; Carvalho, Myrtis de; Toledo, Caio Alves de. Dicionário Universal de Curiosidades. São Paulo: CIL, 1968. Vomero, Maria Fernanda. Morte. Superinteressante, São Paulo, n. 173, p. 36-44, fev. 2002.

Lima-Hernandes, Maria Célia; Teixeira e Silva, Roberval. No descanso eterno entre lápides e epitáfios: São Miguel Arcanjo e Consolação. In: Simas, Monica (Org.). Estudos sobre Macau e outros orientes. São Paulo: Paulistana, 2017. p. 128-168. 


\section{Goa e Macau: às margens do macrossistema literário de língua portuguesa}

\section{Hélder GARMES}

Benjamin Abdala Junior publicou, em 2000, na revista Veredas, órgão da Associação Nacional de Lusitanistas, o artigo intitulado "Terra morta e outras terras: sistemas literários nacionais e o macrossistema literário da língua portuguesa", no qual

1 Hélder Garmes é professor da Faculdade de Filosofia, Letras e Ciências Humanas da USP - Universidade de São Paulo, e pesquisador do GNPq - Conselho Nacional de Desenvolvimento Científico e Tecnológico. Atua nas áreas de Literatura Portuguesa e de Estudos Comparados de Literaturas de Língua Portuguesa. Coordena dois grupos de pesquisa: Pensando Goa, registrado no Laboratório de Interlocuções com a Ásia da USP, e Grupo Eça, registrado no CNPq. Coordena o projeto temático Pensando Goa (proc. n. 2014/15657-8) financiado pela Fapesp, ao qual as reflexões do presente texto estão vinculadas; helder@usp.br 
retomava a noção de "macrossistema literário", que já aparecera em seu livro Literatura, história e política, de 1989, concebida como "um conjunto invariante abstrato", que se materializa em cada um dos sistemas literários nacionais, constituindo assim um "conjunto dialético que envolve a antiga metrópole e suas ex-colônias sem imposições e sem falácia de padrões pretensamente superiores" (ABDALA Junior, 1989, p. 18). No artigo acima referido, a noção de macrossistema literário de língua portuguesa foi retomada nos seguintes termos:

Seria um ponto de encontro dos polissistemas literários da língua portuguesa - um paradigma, logo modelo abstrato, decorrente das articulações dos sistemas literários nacionais. Esse conceito teve sua origem no desejo de se buscar uma base teórica para aproximar as literaturas de língua portuguesa, estabelecendo uma área comum de convergência dos sistemas literários nacionais. Não nos motivava apenas a busca de repertórios provenientes de raízes histórico-culturais comuns, mas também em termos prospectivos de criar bases para aproximações comunitárias, conforme tivemos oportunidade de enfatizar em várias ocasiões. Ao enfraquecimento dos Estados nacionais, parece-nos estratégico, na atualidade, relevar fatores comunitários - uma forma de se contrapor à estandartização dos produtos culturais ligados aos processos de mundialização da economia capitalista. (Abdala Junior, 2000, p. 527)

Poder-se-ia contestar a referida proposição da existência de um macrossistema literário de língua portuguesa, argumentando que ele só se aplicaria a Portugal e ao Brasil, já que não são 
consensuais a existência e consolidação de sistemas literários nacionais nos países africanos de língua oficial portuguesa e muito menos no Timor Leste. Também poderia ser contestada a ideia prospectiva de que uma comunidade linguística supranacional em língua portuguesa propiciaria uma forma de resistência à estandartização dos produtos culturais em escala global, uma vez que, também nesse contexto periférico, sempre há a busca de poder hegemônico de uma parte sobre a outra, reproduzindo em menor escala o que acontece no plano global - como ocorre, por exemplo, na relação do Brasil com o Mercosul, no âmbito, sobretudo, da política e da economia.

No entanto, tais possíveis críticas não desqualificam aquilo que há de mais profícuo na proposição de Benjamin Abdala Junior: a ideia de que o compartilhamento da língua portuguesa em diversas partes do mundo criou certos vínculos históricos e culturais. Tais vínculos não gerariam necessariamente a Comunidade dos Países de Língua Portuguesa que hoje conhecemos sem que a vontade política desses países assim o quisesse. Por razões diversas, questiona-se hoje o sentido e valor dessa comunidade, mas, ainda que amanhã venha a se extinguir, as consequências desses vínculos não serão facilmente apagadas e continuarão a merecer atenção, já que nesse processo houve, em graus e contextos muitos distintos, o vínculo entre literatura e sociedade, entre língua e cultura.

A sobreposição entre língua e cultura não se faz sem diversos graus de complexidade, notadamente quando tomada da perspectiva dos estudos da cultura. Em seu livro A idéia de cultura (2005, p. 52), Terry Eagleton contesta Raymond Williams, que definia cultura por meio de sua sobreposição com o campo de influência de uma língua. Eagleton nota que a língua inglesa, por exemplo, abarca diversas culturas distintas. 
Se é verdade que podemos facilmente identificar várias culturas empregando uma mesma língua, como é o caso do português, é do mesmo modo verdade que, quando uma cultura nacional traz em seu interior várias línguas (como é o caso exemplar da Índia, que possui centenas de línguas), essa cultura nacional compartilha de distintas matrizes culturais. Vale lembrar que o Brasil, apesar de sempre caracterizado como país de uso exclusivo da língua portuguesa, está nessa última categoria, pois conta com a existência das diversas línguas e culturas indígenas. Mesmo Portugal não estaria livre dessa diversidade, se lembrarmos os chamados dialetos guadramilês, rionorês, mirandês e barranquenho.

Estabelecendo uma diversificada gradação de relações, língua e cultura se sobrepõem em diversos aspectos. É quase impossível dissociar completamente uma coisa e outra, ainda quando, por razões históricas, essa relação torna-se muito tênue, como é o caso, por exemplo, do crioulo de Korlai, da costa oeste indiana, cujo povo, além da cristandade, quase nada guarda culturalmente da presença portuguesa naquela região.

Observado dessa perspectiva, o chamado "mundo de língua portuguesa" convive cotidianamente com outras línguas e culturas, sobretudo no antigo espaço colonial: quer no Brasil, quer nos países africanos ou outras partes do globo que sofreram dominação lusitana. Não há como conceber um virtual macrossistema literário de língua portuguesa como um bloco uníssono e coerente. Deve-se tomá-lo em conexão com todas essas outras línguas e culturas, o que acaba se revelando uma tarefa bastante complexa, que só pode se realizar fragmentária e gradualmente.

Faz-se necessário, entretanto, observar que, ao tratarmos de literatura - objeto de nosso interesse - e não de oratura -, estamos lidando com a língua em sua forma escrita. Isso apresenta especificidades, pois sempre nos referimos a uma parcela da 
população desses países que têm acesso a essa forma. Em todos os países de língua oficial portuguesa, há um número, maior ou menor, de indivíduos que não têm acesso à língua escrita. É certo que, em alguns casos, a imensa maioria compartilha desse acesso e, em outros, apenas uma pequena minoria, e isso faz muita diferença na configuração do que se pode designar por cultura nacional letrada de língua portuguesa em cada uma dessas localidades. De qualquer modo, todas as nações que adotaram o português como língua oficial têm hoje uma produção letrada de maior ou menor significação para os membros daquelas comunidades nacionais.

Há, entretanto, casos em que a língua portuguesa foi minoritária culturalmente e que jamais chegaram a constituir nações independentes de língua oficial portuguesa. Ainda assim, geraram uma produção escrita significativa durante séculos e que, após o final do período de dominação lusitana, entraram em franco recuo. Goa e Macau são exemplares nesse aspecto e é sobre tais casos que pretendemos nos deter, pois também a produção literária dessas localidades, em nosso entendimento, pode fazer parte do macrossistema literário de língua portuguesa.

Como é sabido, ambas as localidades foram ocupadas pelos portugueses no século XVI. Goa venceu o jugo lusitano em 19 de dezembro de 1961 e passou a fazer parte do Estado da Índia. Macau deixou de ser território português em 20 de dezembro de 1999, tornando-se uma região administrativa especial da China. Entendemos que refletir sobre essa produção tendo no horizonte o macrossistema literário de língua portuguesa é uma das maneiras mais propositivas de lê-la, já que poderemos retirá-la de seu encapsulamento.

Se é verdade que o trabalho de entender essa produção a partir de seu local de enunciação - Goa e Macau - encontra-se ain- 
da muito incipiente, e temos, com muitos colegas, tentado cerrar fileiras para a concretização dessa tarefa, um outro passo tão importante quanto esse para o entendimento e valorização dessa produção é definir seu lugar, ainda que periférico, no âmbito das literaturas de língua portuguesa.

Sabemos o quanto os países africanos de língua oficial portuguesa têm trabalhado no sentido de se afirmar no cenário literário. Hoje podemos encontrar facilmente nas livrarias brasileiras Mia Couto, Pepetela, Luandino Vieira, Ondjaki, o que há dez anos só ocorreria em Portugal. Esse fenômeno, além da parcela que podemos atribuir ao mercado de livros, se deve a um trabalho bastante denso e arguto de professores universitários brasileiros, que criaram áreas de estudos, centros, departamentos, com o intuito de institucionalizar a literatura de língua portuguesa produzida na África, tratando-a como necessária para a formação do aluno brasileiro. No artigo supracitado, por exemplo, Abdala Junior, ao tratar de Terra morta (1949), de Castro Soromenho, estabelece conexões desse romance com Gaibéus (1939), de Alves Redol, e com a obra de Jorge Amado, assim como com O segredo da morta (1935), de Assis Junior, e com todo o movimento dos Novos Intelectuais de Angola, empenhados na constituição de uma literatura angolana. Vincula, assim, literatura angolana, portuguesa e brasileira, permitindo vislumbrar o que designa de macrossistema literário de língua portuguesa.

A tradição literária africana de língua portuguesa, fosse qual fosse, até recentemente estava marginalizada do processo de formação institucional do leitor brasileiro, que considerava apenas as tradições literárias brasileira e europeia - e alguma coisa da latino-americana. A pressão dos movimentos negro e indígena acabou culminando na Lei n. 11.645/08, de 10 de março de 2008, que instituiu a obrigatoriedade do ensino de "história e 
cultura afro-brasileira e indígena" no ensino fundamental de nossas escolas. Isso possibilitou a valorização das literaturas de língua portuguesa da África, assim como a valorização das culturas e línguas indígenas brasileiras. Consequentemente, o mercado de livros passou a atender também esse novo filão.

É evidente que, em relação à literatura de língua portuguesa produzida em Goa e em Macau, não podemos contar com esse gênero de engajamento social que venha a incluir, algum dia, tais literaturas no currículo escolar brasileiro, português, angolano ou de qualquer outra nação da Comunidade dos Países de Língua Portuguesa. No entanto, temos, no repertório que foi deixado no decorrer de quase cinco séculos, um conjunto de textos que pode contribuir para o entendimento de como literaturas assumidamente periféricas se constituíram às margens de sistemas nacionais. Propicia ainda o estudo, no caso específico de Goa e de Macau, de como aquilo que se convencionou chamar de Oriente e de Ocidente ganhou centralidade constitutiva nessas literaturas, isto é, como tais literaturas se conceberam enquanto expressão dessa tensão entre polos geográficos distintos, que, tal qual postula Edward W. Said (2001), são de fato a forma como designamos a experiência histórica do colonialismo europeu, sobretudo desde o final do século XVIII, tomados aqui no âmbito das literaturas de língua portuguesa. Até o século XVIII, a oposição que vigorava era entre cristãos e "hereges".

Assim, no corpo de textos que hoje constitui a literatura de língua portuguesa de Goa e de Macau, podemos identificar ao menos dois grandes conjuntos de obras: textos publicados antes e depois do século XIX. Até o advento do liberalismo em Portugal, a imprensa de Goa funcionou com alguma regularidade nos séculos XVI e XVII, perdendo força no século XVIII, enquanto a de Macau manteve-se ativa ainda nesse século, até a sua proi- 
bição, por parte do Marquês de Pombal. A primeira imprensa enviada para o espaço colonial foi instalada em Goa em 1556, no Colégio de São Paulo, estampando naquele mesmo ano as Conclusiones philosophicae, tese defendida pelo jesuíta Francisco Cabral. Em Macau, a primeira publicação data de 1588 e intitula-se Christiani Pueri Institutio, do padre Juan Bonifácio de Salamanca (MAtos, 1991-1992, p. 156). Dominada pela Igreja de Roma, a imprensa desses primeiros séculos foi eminentemente católica e, em grande parte, em latim, como é de conhecimento de todos.

A imprensa laica ocorre de fato após o advento do liberalismo. Com o retorno do D. João VI a Portugal em 1821 e a assinatura da Carta Constitucional em 1 de outubro de 1822, Goa e Macau se viram em condições de importar máquinas impressoras e assim teve início a produção do segundo conjunto significativo de textos dessas duas localidades. Os goeses, antecipando-se à assinatura da Carta, trouxeram de Bombaim uma máquina impressora já em 1821, saindo o primeiro número da Gazeta de Goa em 22 de dezembro daquele ano. Macau também se antecipou à assinatura da Carta, sendo o primeiro número do periódico Abelha da China publicado em 12 de setembro de 1822. A partir daí, temos nesses dois espaços de domínio português uma imprensa muito mais dinâmica e volumosa do que aquela promovida pelas missões católicas em séculos anteriores (cf. GARMes, 2004, p. 15-86).

Nesse segundo conjunto de obras, que recobrem os séculos XIX e XX, adentrando ao XXI, faz-se necessário assinalar uma relevante distinção entre a produção de Goa e a de Macau. Enquanto Goa deixa de ser território português em 1961, fazendo com que a produção literária em língua portuguesa sofresse um profundo corte, Macau manteve-se sob domínio português até 
1999, mesmo depois da independência das colônias africanas e do Timor Leste, ocorridas entre 1975 e 1976. A assinatura da Declaração Conjunta do Governo da República Portuguesa e do Governo da República Popular da China sobre a Questão de Macau, de 13 de abril de 1987, que previa o término da administração portuguesa em 20 de dezembro de 1999, acabou por promover, por parte do governo português, uma série de iniciativas que resultaram no estímulo à produção literária de língua portuguesa em Macau, fazendo com que seu escopo literário fosse significativamente ampliado nos últimos anos daquela administração.

Portanto, temos na dinâmica literária em língua portuguesa dessas duas localidades aspectos muito semelhantes, mas também muito distintos. Apenas para citar os trabalhos mais recentes, as especificidades da produção de Macau foram investigadas, por exemplo, por Mônica Simas. Em Margens do destino - Macau e a Literatura de Língua Portuguesa, de 2007, fazendo intersecções com outras literaturas em nossa língua, Simas revela-nos a dinâmica da produção literária de e sobre Macau, de uma perspectiva sobretudo interna, demonstrando o quanto, aos poucos, se desenvolveu ali uma memória do território, assim como um "olhar intérprete", que busca as especificidades daquela cultura. As particularidades da produção de Goa podem ser identificadas, por exemplo, no trabalho de Eufeminano de Jesus Miranda, Oriente e Ocidente na literatura goesa: realidade, ficção, história e imaginação (2012), que reconstitui historicamente aquela tradição de textos literários e procura apontar o que possui de mais específico. Esses dois exemplos demonstram a existência de trabalhos importantes que conseguiram localizar, sistematizar e apresentar interpretações para a dinâmica sobretudo interna dessas literaturas e já delinear algumas de suas relações com o universo literário de língua portuguesa. 
À parte o trabalho de continuidade no aprofundamento do conhecimento de tais especificidades, e contribuindo nesse sentido, faz-se necessário colocá-las mais substancialmente no âmbito do macrossistema literário de língua portuguesa, espaço privilegiado, em nosso entendimento, para evidenciar aquilo que lhes é mais peculiar: seus traços locais. Além dos acima referidos, alguns estudos pontuais e de fôlego já foram realizados nessa perspectiva. No caso de Goa, que é de nosso maior conhecimento, além dos estudos já considerados "clássicos", como os de Filinto Cristo Dias (1963) e Vimala Devi e Manuel de Seabra (1971), podemos lembrar o trabalho de Ana Cristina Kerbauy (2008), que elabora um estudo comparativo entre duas revistas literárias do período do Romantismo: a Ilustração Goana (1864-1866) e a Minerva Brasiliense (1843-1845), abordando as diferentes concepções da relação entre literatura, sociedade e autonomia intelectual que cada uma daquelas publicações apresentava em relação aos contextos nos quais emergiram, concluindo que, tanto no Brasil, ex-colônia de Portugal, quanto na então colônia indiana portuguesa, o processo colonial gerou uma série de contradições que obrigou os emergentes campos de produção erudita a se constituírem sob forte e diversificada ambivalência.

Já o trabalho de João Cunha (2010) aproxima a literatura goesa de língua portuguesa da sua matriz colonial, realizando um estudo comparativo entre o romance Jacob e Dulce: cenas da vida indiana (1896), do goês Francisco João da Costa, e o conjunto da obra de Eça de Queirós, envolvendo ainda uma crítica ao romance elaborada pelo brasileiro Visconde de Taunay e publicada na Revista Brasileira em 1897, revelando dimensões insuspeitas das relações literárias entre Portugal, Brasil e Goa.

Se Everton Machado (2006) demonstrou o quanto o romance Os brahamanes (1866), do goês Francisco Luís Gomes, 
estabelecia uma relação intertextual não somente com a literatura portuguesa, mas também com o romantismo europeu em geral, sobretudo com o francês, em trabalho recente, de 2011, tive a oportunidade de analisar os sentidos da apropriação que o mesmo romance fazia de um dos postulados mais caros ao imaginário colonialista português: a ideia de mestiçagem. Em estudo comparativo (2011) entre o romance de Francisco Luís Gomes e $O$ guarani (1857), de José de Alencar, procurei demonstrar o quanto o imaginário português em torno da mestiçagem, tomada como solução simbólica para o conflito colonial, informa ambos os romances, cumprindo papel muito distinto em cada um deles, por conta dos sentidos que ganha em cada uma dessas localidades.

No caso de Macau, ainda não pude ler investigações pontuais e de fôlego dessa natureza no âmbito da literatura comparada. Além daquele de Mônica Simas, o único trabalho de que tive notícia é de autoria de Wang Suo Ying (1996) e diz respeito à comparação de Amor de perdição (1862), de Camilo Castelo Branco, com o romance $O$ sonho do pavilhão vermelho, de Cao Xueqin, escrito em meados do século XVIII, confrontando, portanto, um texto em português com um texto originalmente escrito em mandarim. Evidentemente trabalhos dessa natureza são muito importantes, uma vez que a literatura comparada não se encontra subordinada à língua original do texto literário. Tratando de comunidades que conviveram e convivem com mais de uma língua, como é o caso de Goa e de Macau, é mesmo fundamental estudar o quanto as tradições literárias das línguas empregadas nessas localidades se encontram entrelaçadas. Todavia, essa é uma outra tarefa.

Quanto ao macrossistema de literaturas de língua portuguesa, vale ainda lembrar uma abordagem muito produtiva a ser adotada: comparar a literatura de Goa com a de Macau, uma 
vez que ambas são forjadas na tensão Ocidente/Oriente, como foi anteriormente observado. Como essa tensão é peculiarmente configurada em cada uma dessas tradições é algo que ainda está para ser descrito e analisado.

No contexto das literaturas de língua portuguesa, as de Goa e de Macau constituem um paradigma diferenciado por serem pouco afeitas ao "instinto de nacionalidade", para empregar a expressão de Machado de Assis (1873/1959, p. 28). São literaturas caracterizadas por aspectos regionais, moldadas, como foi observado, pela tensão entre cristãos e "hereges", entre Ocidente e Oriente, e conectadas de formas diversas com o virtual macrossistema literário de língua portuguesa. Nunca tendo sido a língua hegemônica dessas sociedades, o português promove a constituição de um meio literário bastante entrelaçado às línguas dominantes nessas localidades, como o cantonês e o mandarim em Macau e o concani e o marathi em Goa. Além disso, a produção literária de língua inglesa surge como uma referência importante para essas duas comunidades, por conta da zona de influência de Hong Kong na China e da colonização inglesa na Índia.

Ao propor um esforço mais acentuado e sistemático de leituras comparativas entre as literaturas de Goa e de Macau e as outras literaturas do macrossistema literário de língua portuguesa, nosso intuito é tanto buscar um sentido mais amplo e denso para os textos produzidos naquelas localidades, quanto reconfigurar, a partir da inserção desse novo paradigma, aquilo que já foi escrito sobre a dinâmica das literaturas de língua portuguesa no mundo, redimensionado essa história a partir de suas margens.

Vale finalmente observar que estudar tais literaturas não significa atribuir positividade ao colonialismo português, como já ocorreu no passado, quando A literatura indo-portuguesa, de Vimala Devi e Manuel de Seabra (1971) serviu aos interesses da ditadura 
portuguesa, na busca de demonstrar a suposta portugalidade de Goa. Ainda que marcada muitas vezes pelo ponto de vista do colonizador, é possível estudar de forma crítica essa produção literária, pois apresenta conflitos, contradições e impasses que desafiam o leitor mais perspicaz. O importante é não perder de vista o contexto de enunciação desses textos, que é complexo, contraditório, dinâmico, e no qual sempre vigora a exploração colonial. Ali, velhas formas literárias ganham novos sentidos, novas formas são criadas e, sobretudo, são colocados, ao pesquisador, problemas relativos ao conjunto de valores que se defende quando se procura definir os textos canônicos dessas literaturas, demonstrando que não há como falar de qualidade literária sem que isso envolva referências éticas, políticas, sociais e culturais.

\section{Referências}

Abdala Junior, Benjamin. Terra morta e outras terras: sistemas literários nacionais e o macrossistema literário da língua portuguesa. Revista Veredas, Porto, v. 3-II, Porto, 2000, p. 523-536, 2000.

. Literatura, história e política: literaturas de língua portuguesa no século XX. São Paulo: Ática, 1989.

Alencar, José de. O guarani. Rio Grande: Tipografia do Diário, 1857.

Assis, Machado de. Instinto de nacionalidade. Machado de Assis: crítica, notícia da atual literatura brasileira. São Paulo: Agir, 1959. p. 28-34. Primeira edição publicada em 1873.

Costa, Francisco João da. Jacob e Dulce: cenas da vida indiana. Margão: Tipografia do Ultramar, 1896. 
Gunha, João Figueiredo Alves da. Uma leitura crítica de Jacó e Dulce: cenas da vida indiana à luz do realismo de Eça de Queirós. 2010. Dissertação (Mestrado em Literatura Portuguesa) Faculdade de Filosofia, Letras e Ciências Humanas, Universidade de São Paulo, São Paulo, 2010. 2 v.

Dias, Filinto Cristo. Esboço da história da literatura indo-portuguesa. Bastorá, Goa: Tipografia Rangel, 1963.

Eagleton, Terry. A idéia de cultura. Tradução de Sandra Castello Branco. São Paulo: Editora Unesp, 2005.

GARMes, Hélder. Ímpar entre pares - personagens mestiças e mestiçagem nos romances O guarani e Os brahamanes. 2011. Tese (Livre-docência em Literatura Portuguesa) - Faculdade de Filosofia, Letras e Ciências Humanas, Universidade de São Paulo, São Paulo, 2011.

. Origem e estabelecimento da imprensa e da literatura de Goa. In: Garmes, Hélder (Org.). Oriente, engenho e arte: imprensa e literatura de língua portuguesa em Goa, Macau e Timor Leste. São Paulo: Alameda, 2004. p. 15-86.

Gomes, Francisco Luís. Os brahamanes. Lisboa: Typ. da Gazeta de Portugal, 1866.

Kerbauy, Ana Cristina. Ilustração Goana e Minerva Brasiliense: a sedimentação do romantismo em Goa e no Brasil. 2008. Dissertação (Mestrado em Literatura Portuguesa) - Faculdade de Filosofia, Letras e Ciências Humanas, Universidade de São Paulo, São Paulo, 2008.

LeI n. 11.645/08, de 10 de março de 2008. Disponível em: <http://www.planalto.gov.br/ccivil_03/_ato2007-2010/2008/lei/11 1645. 
htm>. Acesso em: 10 jul. 2017.

Machado, Everton. Christianisme, castes et colonialisme dans le roman Les brahmanes (1866) du goannais Francisco Luis Gomes (1829-1869). 2006. Tese (Doutorado em Literatura Comparada) - Université Paris IV, Paris, e Universidade de São Paulo, São Paulo, 2006.

Matos, Manuel Cadafaz de. A tipografia quinhentista de expressão cultural portuguesa no oriente veículo de propagação dos ideais humanísticos (no quarto centenário da introdução da imprensa jesuítica no Japão). Revista Humanitas, Coimbra, n. 43-44, p. 153-171, 1991-1992.

Miranda, Eufeminiano de Jesus. Oriente e Ocidente na literatura goesa: realidade, ficção, história e imaginação. Bardez: Goa 1556, 2012.

SAID, Edward W. Orientalismo. Tradução de Tomás Rosa Bueno. São Paulo: Companhia das Letras, 2001.

SEAbra, Manuel; Devi, Vimala. A literatura indo-portuguesa. Lisboa: Junta de Investigações do Ultramar, 1971. 2 v.

Simas, Mônica. Margens do Destino: Macau e a Literatura de Língua Portuguesa. São Caetano do Sul: Yendis, 2007.

YING, Wang Suo. Estudo comparado sobre duas tragédias amorosas: O sonho do pavilhão vermelho e Amor de perdição. Macau: Instituto Cultural de Macau, 1996.

GARMES, Hélder. Goa e Macau: às margens do macrossistema literário de língua portuguesa. In: Simas, Monica (Org.). Estudos sobre Macau e outros orientes. São Paulo: Paulistana, 2017. p. 169-183. 
DOI: 10.4322/85-99829-93-6j

\title{
Museus e ruinarias: o orientalismo indiano na poesia de Alberto Osório de Castro
}

\author{
Duarte Drumond BRAGA ${ }^{1}$
}

\section{Introdução}

Embora possa parecer inusitado, faz todo o sentido que o presente volume de estudos, centrado na China e em Macau, contemple a obra de Alberto Osório de Castro (1868-1946). Esse pouco lembrado autor foi um poeta e erudito português, mas também botânico, arqueólogo amador e magistrado da carreira colonial em Goa, Timor e Angola. Além dessa singular combinação de atividades, Osório de Castro foi ainda um dos grandes

\footnotetext{
1 Doutor (2014) em Estudos Comparatistas pela Universidade de Lisboa, seu trabalho se debruça sobre poesia portuguesa do século XX, literatura finissecular, orientalismo na literatura portuguesa e literaturas de Goa e de Macau. O presente texto, desenvolvido a partir da tese de Doutorado Ao oriente do Oriente: transformaçôes do orientalismo em poesia portuguesa do século XX: Camilo Pessanha, Alberto Osório de Castro e Álvaro de Campos (2014), foi terminado com o apoio da Fapesp, no âmbito de bolsa de Pós-doutorado 2014/008298 e do Projeto Temático Pensando Goa 2014/15657-8; duartedbraga@gmail.com
} 
instigadores de um gosto oriental na poesia e prosa portuguesas da virada do século, no que é acompanhado por outros autores de sua geração como Jaime do Inso, Venceslau de Morais e Camilo Pessanha. Mas o caso de Osório Castro é determinante e singular, pela amplitude e intensidade de seu trabalho poético e erudito. Trata-se de uma obra poética pensada em torno do Oriente, o centro do seu investimento enquanto estética e enquanto fonte de conhecimento, devido à sua riqueza referencial e erudita. Nesse duplo sentido, a poesia osoriana consegue ser como que o mostruário poético de um Oriente plural: a recuperação lírica da Índia dos Vedas e do século XVI, o japonismo e chinoiserie europeus que também atravessa sua primeira obra; a Oceânia com o exotismo indonésio de Flores de Coral (1909), são esses alguns dos Orientes com os quais contactou de modo directo. Temos ainda toda uma série de Orientes históricos, como o Egipto, a Pérsia e a Assíria, o que se traduz em poemas de erotismo decadente, mas também em pioneiras traduções de géneros líricos desses mundos. $\mathrm{O}$ conjunto de tais práticas estéticas diz respeito às tradições internas, bem como às geografias diversas do orientalismo europeu.

Assim, o orientalismo de Osório de Castro prende-se ao facto de a sua poesia nunca perder a sua dimensão europeia e cosmopolita, na qual se funda ideológica e sobretudo simbolicamente. Essa dimensão cosmopolita admite a errância por lugares que estendem esse mesmo cosmopolitismo ao não europeu, mas que fazem sempre do lugar onde está a solidez, ao modo do exota de Victor Segalen, uma casa de onde nunca se perde de vista a cultura europeia. E, se o sujeito, tal como na proposta de teorização do exotismo de Segalen (2007), se assume como inscrito na 
cultura europeia, ${ }^{2}$ ele não vai deixar de exibir conexões vitais ao discurso imperial e colonial. Com efeito, essa obra poética dá voz a uma dimensão de poder que parte de um eu lírico masculino, instituído a partir do texto e do paratexto, protagonizador de vários poemas de cenário marítimo, colonial e oriental a partir de Exiladas, tecendo óbvios laços com a instância autoral, sobretudo com o burocrata colonial e representante do Estado Português que é o autor empírico, fazendo com que o seu Oriente nunca deixe de se fundar na prática e num percurso imperial, o que força a remeter para o modelo crítico de Edward Said (2004).

\section{Saber e culturalismo: a Índia em A Cinza dos Mirtos}

Arqueólogo e botânico amador, Alberto Osório de Castro funda em Goa, ${ }^{3}$ onde vive entre 1893 e 1907, a densa, erudita revista com o programático nome O Oriente Português, longeva publicação (durará até os anos 1940) da Comissão Arqueológica da Índia Portuguesa. Desde 1903, faz parte dessa comissão. Para quem poderia não ter sido mais do que um mero burocrata da ordem colonial, é notável encontrar nos artigos aí editados a valoração social das línguas e das artes locais. ${ }^{4} \mathrm{O}$ afastamento

2 "L'exote, du creux de sa motte de terre patriarcale, appelle, désire, subodore des au-delà" (SEgalen, 2007, p. 67).

3 Aqui desempenhou, antes de mais, os cargos de Procurador da Coroa e Fazenda e Juiz de Direito entre 1894 e 1907 (Oliveira, 1959, p. 32). Em 1907, é juiz de direito da comarca de Moçâmedes (Angola). No mesmo ano pede transferência para Timor. Em 1911, está em Angola, na relação de Luanda, de onde pede transferência (definitiva) para a Metrópole. Afirma a mesma autora: "Esteve primeiro em Margão e depois em Nova-Goa".

4 É em O Oriente Português que defende o ensino artístico na colónia: "Urge encontrar os veios puros de todas as artes indígenas" (Osório DE CASTro, 1906b, p. 483) e o ensino do mahratti e do concani em escolas do estado, tal como Cunha Rivara havia defendido 
da metrópole não encontrará, pois, um Osório de Castro entregue apenas à literatura, mas um cidadão política e culturalmente muito activo, inteligindo o seu percurso no contexto do orientalismo académico nacional e internacional. $\mathrm{O}$ autor é, aliás, em todos os territórios onde poderá ser encontrado, figura muito activa na intervenção sócio-cultural e na investigação erudita, sendo que a poesia, tardando sempre a ser reunida em volume, dir-se-ia não uma actividade de segundo plano mas, mais interessantemente, uma actividade que recebe evidente interpenetração daquelas áreas. A Cinza dos Mirtos (1906), por exemplo, livro de versos publicado em Nova Goa, em muito se articula com os treze anos aí passados, como que coroando o termo dessa estada. É do território do Estado da Índia (não apenas de Goa) que são datados a esmagadora maioria dos poemas, em articulação com um "Glossário de termos indiáticos e indo-portugueses", cheio de erudição e de conhecimento da realidade local e um amplo material iconográfico. Tudo isso relaciona-se de forma muito directa com a sua permanência na colónia, embora o livro extravase tal ambiente.

O volume, fixando-se nas preocupações esculturais da poesia parnasiana da qual, porventura, nunca se evadirá totalmente, integra, de forma mais madura, já longe da necessidade de épater le bourgeois, a herança estética decadentista do livro anterior, a começar pelo título que, retomando o do livro anterior, possui o timbre "simbolista" da flor consumida, isto é, das desenganadas esperanças da juventude. Porém, quer a flor, quer a sua simbologia, nada têm de indiano, enviando de forma clara para

em relação ao concani, considerado, contudo, menor face ao primeiro. Osório de Castro afirma, de forma surpreendente: "Um povo que não perdeu de todo a língua de seus maiores, nem adoptou por completo a língua dos estrangeiros dominadores, é, [...] como um amputado, sempre dolorido da amputação" (Osório DE CASTRO, 1906c, p. 485). 
a mitologia greco-latina, o que significativamente coroa um livro dedicado, na sua quase totalidade, ao cenário indiano.

A Cinza dos Mirtos é, pois, um livro que quer ser lido como um museu poético-visual da Índia, em particular da chamada Índia Portuguesa ou Estado Português da Índia (Goa, Damão e Diu), mas também da Índia clássica ${ }^{5}$. Essa poesia torna-se aqui, mercê desse gesto, culturalista, a que corresponde uma pesada carga de erudição, plasmada num enciclopedismo baseado nas "artes" e nas "ciências". Por culturalismo se entende que são, antes de mais, os modelos histórico-culturais e literários que se colocam como lentes primeiras para a observação da realidade. As fórmulas culturais, fixadas a priori, assumem-se como enquadramentos básicos nos quais se vem inscrever a realidade empírica. A constante inserção de termos, em A Cinza dos Mirtos, bem como em Flores de Coral, de diversas línguas que não o português é um aspecto formal, bem visível, do seu culturalismo. Impressiona a poliglossia dessa poesia, com recurso a várias línguas europeias, citadas no original nas notas, ou incluídas nos poemas (inglês, francês, mas também neerlandês e alemão) e asiáticas (toda a panóplia de línguas locais, como o concani, o mahratti e outros idiomas da Índia, na primeira obra, e o malaio ou o tétum na segunda), o que perturba de forma muito interessante a língua portuguesa $^{6}$.

5 "Sati", por exemplo, é dos poucos exemplos poéticos de um interesse, ainda que aprofundado, pela Índia clássica. Esse interesse presentifica-se, contudo, de uma forma mais clara ao longo das fartas notas.

$6 \mathrm{Na}$ primeira obra, o glossário ainda desempenha de forma clara a função elucidativa que lhe é esperada, o que não será o caso das notas de Flores de Coral, como se verá. A poesia de Osório de Castro pretende ser um mostruário de aspectos culturais do Oriente português. Deste modo, não se trata apenas do estranhamento vocabular, mas sobretudo da preservação de um vocabulário local, como mostra o poema «Bahisinha»: "Vestidinha de cassa, a boca purpurina/ Como as ixoras de madrugada,/ Na quitunde de rota e a 
O catálogo, ${ }^{7}$ instrumento básico de classificação museológica e de condução do olhar pela exposição do saber, é uma forma que estrutura visualmente esse livro. Verifica-se, com efeito, que todas as imagens que ilustram a obra são retiradas da revista que funda e dirige em Goa, O Oriente Português, compiladas num catálogo elaborado pelo próprio Osório de Castro (1907, p. 42-48). Trata-se de reproduções de antiguidades, na sua maioria anteriores à chegada dos portugueses, tais como fragmentos de templos e de outros edifícios por eles destruídos, a cuja recolha e até mesmo musealização o poeta esteve ligado. Vai, assim, semeando nas margens dos textos esses significantes pictóricos.

É, com efeito, nas margens dos textos que se revela o museu colonial em todo o seu vestigial esplendor, reunido a partir dos detritos heteróclitos pelo olhar do esteta, duplicado em cientista. É o que, segundo Helena Buescu, podemos designar como o "não-moderno" (2005, p. 21), o arcaico metonimizado nos objectos artísticos arcaicos, que se torna aqui perceptível enquanto fronteira com o moderno, enquanto um conjunto de elementos convocados para marcar essa fronteira, como a ensaísta portuguesa propõe sob essa categoria crítica. Esse processo tra-

cêlha acharoada/ Guarda os pilouros de linha fina./ Com seu claro cabelo os dois nomes bordara/ Da longa espada sobre o talim./ Ai! Se a boca inda à de ele à noite não colara,/ Ente os quisquális do varandim!...” (Osório DE CASTRO, 1906a, p. 270).

7 As imagens da edição de 2004 apenas parcialmente reproduzem as que se encontram na primeira. É de notar ainda que o baixo-relevo representado na capa da revista a partir do ano de 1907 é o mesmo que será reproduzido na capa brochada de A Cinza dos Mirtos. Nas notas a essa obra, explica tratar-se do cenotáfio de D. Catarina, mulher do Governador Garcia de Sá, existente na Igreja do Padroado do Rosário em Velha Goa: "É persa o túmulo? Hindu antes? Um produto das duas artes talvez, mas feito em Ormuz, provavelmente" (Osório dE CASTro, 1906a, p. 287). Consultou-se a esse respeito o historiador Doutor Sidh Mendiratta, que confirmou ser esta peça, provavelmente originária de Diu, ainda visitável na dita igreja. 
duz-se no seguinte: os materiais culturais desenterrados do passado luso-oriental ascendem aos modelos - outro tipo de arqués, para continuar a metáfora arqueológica - da moderna representação estética, bebidos na literatura orientalista francesa e britânica. $\mathrm{O}$ arcaico, que contém em si a arqué - étimo de arqueologia, remetendo para princípio ou modelo primevo - de valor histórico-cultural, torna-se o conteúdo usado para preencher uma forma sensível: o poema. De facto, a metáfora arqueológica pode aqui tornar-se literal, representativa do que o texto faz, além do que $d i z^{8}$, como a certa altura o glossário deixa transparecer, ao referir-se a uma descoberta feita pelo próprio em Goa: "Encontrei os fundamentos desta porta" (Osório De CAstro, 1906a, p. 284). Não só descobre a porta, como inscreve tal descoberta no texto, que assim prolonga e mimetiza o gesto arqueológico.

Regressando à figura do museu, este é já o locus moderno da performatização do conhecimento europeu do arcaico. O museu auto-figura-se como atemporal, de acordo com o carácter pretensamente trans-histórico da razão eurocêntrica, a única que possuiria a visão totalizante de todas as eras. Segundo a leitura de Anne McClintock, o museu define-se como " $\mathrm{t}] \mathrm{he}$ modern fetish-house of the archaic" (Mccintock, 1995, p. 40), espaço onde o que é performatizado seria o que a autora denomina como o espaço anacronístico; isto é, a relação entre um certo arcaico que é tido como contemporâneo ao moderno. Naturalmente, o outro "oriental" surge como uma boa ilustração de tal noção, enquanto pré-histórico que subsistiria na contemporaneidade, enquanto o outro africano corresponderia ao elemento

8 Trata-se de uma passagem da nota "Serra", do glossário: "Afonso de Albuquerque mandou levantar às duas portas dos Baçais [...] a sua ermida ou capela [...]. Numa capela deste templo foi enterrado, e que ficava sobre a porta ocidental dos Bachares. Encontrei os fundamentos desta porta" (CASTRO, 1906a: 284). 
que, de forma plena, seria a-histórico. A linearidade da ideologia do progresso é responsável pela espectacularização, como nota a mesma autora, da produção do saber europeu colonial como conhecimento unificado ao nível espácio-temporal - "unified world time" (Mcalintock, 1995, p. 57) -, apresentado ao seu próprio consumo como nova forma de comodidade cultural ${ }^{9}$.

Não interessa, porém, listar na obra de Osório de Castro os ecos esperáveis dessas manifestações do pensamento e da cultura europeia oitocentista. Será menos óbvio retirar de toda essa reflexão a forma como Goa, ou melhor, o livro que a representa, se torna - ao jeito da figura do museu com seu tempo e espaço de simulacro - um simulacro de museu, enquanto exibição (no sentido museológico) intersemiótica da Índia. Ora, tal dar-se-ia, no caso da estrutura de um livro como A Cinza dos Mirtos, pela exposição de elementos pictórico-visuais dentro da esfera textual, de forma comprometida com um programa concreto de exposição do saber. Nesse sentido, o orientalismo português que se pode retirar dessa obra é não apenas um espaço estético-poético, mas também disciplinar-institucional.

É ainda no sentido dessa última leitura que deve ser interpretada a inscrição intersemiótica das artes plásticas e da música no poema, como se evidencia na inclusão de pautas de canções tradicionais goesas, denunciando a presença da investigação etnográfica ${ }^{10}$. Muitos desses elementos marcam de forma gráfica os poemas. É curioso notar que a escrita poética dessa obra não acompanha - presa a um esteticismo de signo parnasia-

\footnotetext{
9 Na expressão da autora: "[...] mass consumption of time as a commodity spectacle" (MCGLINTOCK, 1995, p. $5^{7)}$

10 Com efeito, a relação entre literatura, etnografia e antropologia voltará a estar presente em Flores de Coral. Seria merecedora de toda uma investigação que, nese contexto, não é possível ser empreendida.
} 
no e a uma dicção neo-romântica e neo-épica - a intensidade do seu pensamento do livro enquanto objecto. Esse, que de algum modo já se encontra presente no duplo índice de Exiladas (1895), manifesta-se sobretudo a partir do volume de 1906. De toda a forma, o esteticismo que caracterizaria, segundo Drucker (1994), o chamado livre d'artiste, permite explicar o que acontece em A Cinza dos Mirtos, no sentido de um decorativismo que procura as marcas gráficas e editoriais ${ }^{11}$ do exótico. Esse interesse pela materialidade da página prefigura, por outro lado, a atenção que as Vanguardas lhe concederão. É, sem dúvida, todo o carácter instável do livro, em Osório de Castro, que levou um crítico como Fernando Cabral Martins a buscar uma solução inesperada para a classificação estético-periodológica dessa poesia:

Aí [Em Flores de Coral] torna-se modernista no sentido próprio, não só por esse redobramento do poeta e do observador científico, mas pela injunção a Marinetti [...] ou D'Annunzio [...] e sobretudo pelo carácter compósito do livro, múltiplo, livre, solto, indo em varias direcções ao mesmo tempo. (MarTins, 2008, p. 150)

Porém, o mais decepcionante para um leitor de hoje, relativamente à manifestação poética daquela pulsão museográfica que atrás se debateu, é a acomodação de $A$ Cinza dos Mirtos ao registo estético neo-romântico, que, contudo, não passa para o seguinte, Flores de Coral (1909). Tal registo possui um vínculo com a intenção de fixar uma museografia e arqueologia poéticas da Índia Portuguesa, dos seus episódios românticos de paixão e morte

11 Ao nível da escolha exótica de papel para uma das tiragens de Flores de Coral. 
da era heróica do Império, ainda que o orientalismo osoriano conviva com um conhecimento muito aprofundado da cultura clássica indiana. Tal demonstra, de uma forma muito evidente, o filtro do conhecimento orientalista inglês, mas também francês e holandês, ainda que em menor grau. Nesse sentido, o Neo-romantismo terá surgido ao autor como o registo que melhor catalisaria tal pulsão museográfica ${ }^{12}$. Uma das coisas que interessa ressaltar é que esse tipo de composição, flexão epocal de cenas da Goa do século XVI e XVII, é feito com base na leitura de crónicas portuguesas do século XVI como Lendas da Índia (1858-1863), de Gaspar Correia, ou a História Trágico-Marítima (1735-1736), bem como d'Os Lusíadas, denunciando o uso das fontes portuguesas ${ }^{13}$ na construção de um imaginário orientalista da Índia. A esse respeito, há contudo a fortíssima contribuição do conhecimento britânico sobre a Índia clássica, muito insistente nas notas. A recuperação poética das fontes portuguesas deve ser contextualizada na efusão patriótica de signo neo-româno que deu origem a várias produções literárias em torno do Quarto Centenário da Índia (1898), como algum teatro, ficção e poesia de circunstância.

12 Liga-se esse tom a variados poemas de A Cinza dos Mirtos: «Diu», «Sombras de Diu», «Na Cerca de são Francisco de Goa», «A Morte de Dom João de Eça», entre outros.

13 Trata-se de fontes uma vez que, em rigor, não são apenas obras literárias mas, muitas delas, fontes históricas averbando o conhecimento português sobre a Índia. Dos textos portugueses antigos, comparecem não só os literários, como Camões, mas sobretudo os históricos, como o famoso Colóquio dos Simples (1563) de Garcia da Orta (1501-1568); Fernão Lopes Castanheda (1500-1559), com sua volumosa História do Descobrimento \& Conquista da Índia pelos Portugueses (1552-1561); a Descrição da Fortaleza de Diu (1634) de António Bocarro e ainda, de Gaspar Correia (1495-1565), as Lendas da Índia (1858-1863). Encontram-se, outrossim, as fontes portuguesas e indo-portuguesas modernas, como a obra de Sebastião Dalgado, de Cunha Rivara, ou ainda de António Emílio d'Almeida Azevedo (1857-1923), bem como a própria revista Oriente Português. 
Vejamos agora um poema de A Cinza dos Mirtos que de alguma forma procura sintetizar um orientalismo português em torno da Índia:

Ó novenas de Goa, ardentes e floridas,

Alma de um tempo morto a envolver todo o altar,

Já nada me dizeis, vozes estremecidas

De um pobre Portugal naufragado além-mar.

São ruinarias só, parasitas crescidas

Nos bastiões da muralha e o brasão do solar.

Só chama o Sino de Oiro, entre igrejas caídas,

Ao tigre que dormita e à cobra a rastejar.

Dos mortos nem o pó recobrem os moimentos.

Passaram as monções, os grandes sóis, os ventos,

E foi disperso tudo, o nosso pó levado!

Uma gota de sangue apenas, nada mais!

Mas em flores ocultas escombros do passado,

Índia escarlate! e alarga as raízes imortais.

(Osório De CAstro, 1906a, p. 204)

Em poemas de ambiência similar de A Cinza dos Mirtos, como "Goa" ou "Chiquinha", a ex-colónia portuguesa é denominada a "Cidade Morta", termo que deverá referir-se às ruínas portuguesas de Velha Goa e, por sinédoque, a toda a Índia Portuguesa e mesmo a todo o Oriente Português. O tema da Cidade Morta sugere, com efeito, o declínio da Roma do Oriente após o período quinhentista e seiscentista. Goa é ainda uma sinédoque 
do que Osório de Castro, em nótula, designa "tragédia luso-oriental" (Osório De CAstro, 1906a, p. 192). Esse é um tema recorrente na poesia e ficção portuguesas dos séculos XIX e XX acerca da Índia, como é o caso de Tomás Ribeiro, António Manuel Couto Viana ou de José Augusto Seabra.

O soneto explicita uma situação de "lamento sobre as ruínas" como cenário-chave da relação do "pobre Portugal naufragado além-mar" com a Índia e o Oriente. De alguma forma o topos clássico da lamentação sobre as ruínas de Cartago seria um dos motivos centrais no relacionamento do moderno poeta português com o Oriente, no qual sempre surge a oposição entre o Oriente imperial de outrora e o Oriente contemporâneo, que já não espelha nem permite resgatar as "glórias" do Quinhentos. Tal como no poema "Sino de Ouro", do livro Vésperas (1880), de Tomás Ribeiro, explicitamente aludido na segunda quadra ${ }^{14}$, são os elementos religiosos que, abrindo a primeira estrofe, sinalizam a presença toldada de um Portugal que já dificilmente se deixa ler em seus sinais "orientais": Ó novenas de Goa, ardentes e floridas,/ Alma de um tempo morto a envolver todo o altar,/Já nada me dizeis, vozes estremecidas/ De um pobre Portugal naufragado além-mar" (Osório DE CAstro, 1906a, p. 204).

Esta elegia da memória imperial apenas pode contemplar um conjunto de ruínas dessa Índia gloriosa do século XVI, numa sobreposição fantasmática à matéria do presente. Trata-se, assim, de um processo que pode ser aproximado àquele a

14 "Tange, sino d'ouro, tange/ Na velha torre da Sé,/ Que se o teu som se refrange/ nos ecos da solidão,/se das abóbadas rotas,/que estão ruindo a pedaços,/ te responde o furacão,/ talvez que aos heróis d'Ormuz,/ de Chaul, Diu e Ceilão,/ Quebres o selo da morte/ E acordes o coração./ Era tão grande e tão forte!.../ Puderam com tantas mágoas/ e ganharam tanta glória/ sobre a terra e sobre as águas.../ E são tão vivos na história!" (Ribeiro, 1880, p. 138). 
que Camilo Pessanha se referira, num artigo de jornal publicado em Macau em 1924 e intitulado «Macau e a Gruta de Camões» (1924), como um enternecimento "ante as ruínas da antiga grandeza da pátria" que caracterizaria o que, no mesmo texto, denomina a "reduzida obra poética colonial" (Pessanha, 1924, p. 304) de autores como Tomás Ribeiro, Alberto Osório de Castro e o goês Fernando Leal. Vejamos a passagem central do texto:

Os poucos [poetas] que vagueiam e se definham por longínquas regiões, se acaso escrevem em verso, é sempre para cantar a pátria ausente, para se enternecerem (os portugueses) ante as ruínas da antiga grandeza da pátria e, sobretudo, para dar desafogo à irremediável tristeza que os punge E se na reduzida obra poética colonial desses escritores - Tomás Ribeiro, Alberto Osório de Castro, Fernando Leal (este último nascido na Índia, mas nem por isso menos exilado ali, português como era pelo sangue e pela educação) - se encontram dispersos alguns traços fulgurantes de exotismo, é só para tornar mais pungente pela evocação do meio hostil e inadequado pela sua estranheza à perfeita floração das almas - a impressão geral de tristeza - da irremissível tristeza de todos os exílios (Pessanha, 1992, p. 304).

Nesse poema, os dois tercetos que o encerram são a manifestação dessa ideia do texto de que, de alguma forma, a poesia orientalista portuguesa seria sempre uma forma de lamentação sobre as ruínas do império, o que a parece pôr em causa quando confrontada com outros orientalismos europeus, preocupados não tanto em encontrar fantasmas e fragmentos de Portugal no 
Oriente como forma privilegiada de escrita orientalista, mas em desenvolver uma evocação da pura alteridade, tais como Hearn, Moraes ou Loti, expressamente citados no texto em causa. Decididamente, o soneto de Osório de Castro trata mais de uma identidade posta em causa do que de uma alteridade, sendo que o império que o poeta retrata é uma espécie de devir póstumo de si mesmo, perante o qual o olhar não consegue ser mais do que a contemplação ruinosa do passado: "Dos mortos nem o pó recobrem os moimentos./ Passaram as monções, os grandes sóis, os ventos,/ E foi disperso tudo, o nosso pó levado!"' (Osório DE Castro, 1906a, p. 204).

Assim, e pegando na segunda ideia do fragmento crítico de Pessanha, a de que os "traços fulgurantes de exotismo" apenas serviriam para fazer contraste com "as ruínas da antiga grandeza da pátria" (1924, p. 304), e seria nesse sentido que poderíamos ler o "tigre que dormita e à cobra a rastejar" (OsóRIO de Castro, 1906a, p. 204), bem como todo o cenário hostil das "monções, os grandes sóis, os ventos", que, geração após geração, apagam os sinais da presença portuguesa, destroem os monumentos e fazem as árvores criar raízes sobre os brasões das famílias dos conquistadores. O poema termina assim a sua difícil arqueologia imperial: descobrir os sinais de um Portugal enterrado não só sob entidades omnívoras como a Índia e a China, mas também sob os restos de camadas de outros impérios europeus. O sangue dos heróis lusos torna-se assim parte espiritual da Índia, que surge sob o tópico orientalizante da Índia imortal, entidade omnívora que tudo digere, continuando a subsistir sobre os escombros de todos os impérios esquecidos, dissolvidos como meras faces suas: "Uma gota de sangue apenas, nada mais!/ Mas em flores ocultas escombros do passado,/ Índia escarlate! e alarga as raízes imortais" (Osório de CASTRO, 1906a, p. 204). 


\section{Conclusão}

A Cinza dos Mirtos (1906) é um livro que patenteia uma formação estética orientalista bebida nas literaturas oitocentistas francesa e inglesa, mobilizando tal herança para a representação dos enclaves coloniais portugueses na Índia. Por outro lado, a renovação da construção estética de uma geografia oriental na poesia portuguesa prende-se, de forma decisiva, com a memória cultural e mítica de um império que o tempo do poeta veio encontrar fragilizado nessas paragens. Nesse sentido, talvez o maior interesse que a poesia de Alberto Osório de Castro poderá ter para o leitor do dealbar do século XXI passe pelo facto de ser uma poesia "exterior" e "objectiva" (Pessanha, 1992, p. 109) - para usar aqui termos críticos da resenha de Camilo Pessanha ao livro Flores de Coral, publicada em 1910 - face aos territórios, culturas e literaturas com os quais contactou. Procuramos a poesia de Osório de Castro para conhecer uma proposta estética aberta ao elemento erudito, científico e didáctico acerca do Oriente colonial português da virada do século, abrindo-nos um vasto leque de informações, bem como uma visão global das linguagens internas do Orientalismo europeu, desde a recepção finissecular do orientalismo francês à construção de um orientalismo português em torno da Índia, muito vibrante no fim-de-século. Esse orientalismo de que aqui falamos deve ser lido, como esse texto procurou apontar, como linguagem ao mesmo tempo dependente das estruturas sociais que replicam a organização do saber colonial europeu, importando os epistemas produzidos no contexto disciplinar inglês e francês (museus, catálogos) e, por outro lado, revisitadora de uma narrativa própria, feita a partir dos temas, elementos estéticos e simbólicos e das paisagens de uma Índia que se inscreve na história imperial de Portugal. 


\section{Referências}

Buescu, Helena Carvalhão. Cristalizações: fronteiras da modernidade. Lisboa: Relógio d’Água, 2005.

Drucker, Johanna. The Visible Word: Experimental Typography and Modern Art. 1909-1923. Chicago: The University of Chicago Press, 1994.

Martins, Fernando Cabral. Alberto Osório de Castro. In: Martins, Fernando Cabral (Org.). Dicionário de Fernando Pessoa e do Modernismo Português. Lisboa: Caminho, 2008. p. 312.

Mcalintock, Anne. Imperial Leather: race, gender and sexuality in the colonial contest. New York: Routledge, 1995.

Oliveira, Ana Maria da Conceição. Alberto Osório de Castro: Ensaio Bio-Bibliográfico e Crítico. 1959. Tese (Licenciatura em Filologia Românica) - Faculdade de Letras da Universidade de Lisboa, Lisboa, 1959.

Osório de Castro, Alberto. Exiladas. Livro de Versos. Coimbra: Francisco França Amado - Editor, 1895.

Osório de Castro, Alberto. A Cinza dos Mirtos. Nova Goa: Imprensa Nacional, 1906a.

Osório de Castro, Alberto. Proposta de Reorganização do Ensino Profissional em Groa. O Oriente Português: Revista da Comissão Arqueológica da Índia Portuguesa, Nova Goa, v. 3, n. 12, p. 480-483, dez. 1906b.

Osório de Gastro, Alberto. Proposta sobre o Ensino de Concani nas Alas de Mahratti em Goa. O Oriente Português: Revista da Comissão Arqueológica da Índia Portuguesa, Nova 
Goa, v. 3, n. 12, p. 484-486, dez. 1906c.

Osório de Castro, Alberto. Catálogo do Real Museu da Índia Portuguesa. O Oriente Português: Revista da Comissão Arqueológica da Índia Portuguesa, Nova Goa, v. 4, n. 1-3, p. 42-48, jan./mar. 1907.

Osório de Castro, Alberto. Flores de Coral. Dili: Imprensa Nacional, 1909.

Pessanha, Camilo. Macau e a Gruta de Camões. In: Pires, Daniel (Ed.). Camilo Pessanha Prosador e Tradutor. Macau: Instituto Português do Oriente, 1992. p. 301-305.

Ribeiro, Tomás. Vesperas: poesias dispersas. Lisboa: Livraria Internacional de Ernesto Chardron, 1880.

SAID, Edward. Orientalismo. Lisboa: Cotovia, 2004.

Segalen Victor. Essai sur l'Exotisme: une Esthétique du Divers. Paris: Fata Morgana, 2007.

Braga, Duarte Drumond. Museus e ruinarias: o orientalismo indiano na poesia de Alberto Osório de Castro. In: Simas, Monica (Org.). Estudos sobre Macau e outros orientes. São Paulo: Paulistana, 2017. p. 184-200. 


\section{Os paclé (portugueses) em narrativas goesas de língua portuguesa ou o "mimetismo regrado"}

\section{Everton V. MACHADO'}

Há um termo indo-português, com origem na língua natural de Goa, para designar o português: pacló (plural paclé, feminino paclina). Supõe-se que venha do vocábulo concani $p a k h$, "“pena' ou 'pluma', que teriam os militares nos seus chapéus ou bonés" (DALGADO, 1921, p. 128). Não deixa de ser curioso tal termo se ter forjado sob a evidência ela mesma da autoridade colonial, já que servia, inicialmente, para nomear os agentes repressores numa maior proximidade com a população, os soldados da

1 Investigador Auxiliar da Faculdade de Letras da Universidade de Lisboa. Vice-diretor do Centro de Estudos Comparatistas e coordenador do grupo de pesquisa "Orientalismo Português - séculos XIX e XX". Docente nos programas de mestrado e de doutoramento em Estudos Comparatistas, Língua e Cultura Portuguesa e Comunicação e Cultura. Desenvolve o projeto "The Portuguese Representations of India: Power and Knowledge in a Peripheral Orientalism (XIX and XX centuries)", financiado pela Fundação para a Ciência e a Tecnologia de Portugal (IF/01452/2013), com duração de cinco anos (2013-2018); evermachado@gmail.com 
Coroa Portuguesa. Mais tarde, veio também a ser aplicado aos membros das elites locais, pelo seu grau de aproximação à cultura ocidental. Fala-se até em paclocultura, como recorda Maria Aurora Couto:

O resultado das políticas coloniais para erradicar a cultura e a língua materna tradicionais é bastante evidente: nas castas altas, os que trabalhavam dentro do sistema mudaram muito mais do que os que trabalhavam na terra, a menos que se tratasse de proprietários abastados. Como costumava dizer Raul Fernandes, professor de liceu e famoso humorista, a cultura de Panjim é a paclocultura, a cultura do homem branco. [...] Quanto à classe trabalhadora ou campesina, eram pessoas que viviam com a sua nova fé e tinham escolhido o que pretendiam e conseguiam preservar, sem dar muito nas vistas. Nunca aprenderam o português. Não tinham nada a perder nem a ganhar. (CouTo, 2012, p. 164-165)

Em textos escritos tanto por portugueses quanto por goeses, nota-se uma diferença de atitude destes para com os primeiros ou o que Portugal simboliza, diretamente relacionada com o tipo de aproximação que os locais mantinham com o poder colonial. No caso da classe campesina acima referida, o romance $O$ Signo da Ira (1960), de Orlando da Costa (1929-2006), sugere uma relação com os portugueses marcada sobretudo pelo medo. A narrativa aborda, já no século XX, a vida dos curumbins (agricultores) e um entorno que é o mesmo no qual terá surgido o termo pacló: o dos soldados portugueses. Não partilhando com as classes mais altas os costumes e a língua portugueses, apenas a religião cristã, essa classe sempre foi, de resto, mais permeável a práticas sociocultu- 
rais e religiosas oriundas do meio hindu, ${ }^{2}$ cuja visão dos paclé, por seu turno, e a julgar pelo que escreveu em finais do século XIX o agrónomo português António Lopes Mendes (1835-1894), não era diferente: "os gentios das Novas Conquistas 3 fugiam do pacló (europeu) como o diabo da cruz" (Mendes, 1886, p. 63). No caso das elites mimetizadas, beneficiárias do poder colonial e concorrendo para o bom funcionamento deste, o quadro é bem outro: os portugueses são objeto ou de fascínio ou de total desprezo. Para se compreender adequadamente as representações que daí derivam, faz-se necessário observar não apenas como os portugueses são retratados, mas também as próprias elites nativas, em articulação com a conjuntura sócio-histórica e política.

A representação dos paclé nas narrativas (conto e romance) da literatura chamada "indo-portuguesa" que aqui serão referidas confirmam, antes de mais, aquilo que a etnomusicóloga Susana Sardo, estudiosa da cultura de Goa, chamou de "mimetismo regrado", tal noção podendo ser utilizada na área dos Estudos Literários como grelha de leitura ou mesmo conceito operatório para se identificar com clareza as nuances dos discursos observados ou situá-los devidamente nos contextos que lhes são próprios. Escreve a especialista:

2 "O apego aos costumes é mais forte nas castas baixas, muito menos tocadas pela influência portuguesa e mais próximas da tradição hindu” (Thomaz, 1994, p. 274). Vejam-se os romances Bodki (1962), de Agostinho Fernandes, e O Último Olhar de Manú Miranda (2000), de Orlando da Costa, que abordam crenças e costumes originados a partir de cultos primitivos locais.

3 Chamadas desta forma as terras conquistadas pelos portugueses em Goa apenas em finais do século XVIII (Perném, Bicholim, Satari, Pondá, Sanguém, Quepém e Canácona), por oposição às "Velhas Conquistas" do século XVI (as "ilhas" de Goa e as províncias de Bardez e Salcete). 
[...] perante um quadro que apresenta por um lado uma organização política constituída por uma população flutuante de portugueses, minoritária, da qual dependem as decisões políticas, administrativas e militares de Goa e, por outro, uma população fixa, maioritária, profundamente organizada e hierarquizada, de consolidadas relações internas de poder, da qual depende o equilíbrio social e cultural da população católica e hindu de Goa, parece claro que a fragilidade natural do poder colonial só poderá ter sido superada através da cumplicidade de uma elite local que entretanto se sedimentou e cujo interesse de manutenção provinha das duas esferas de influência: a portuguesa e a goesa. Podemos dizer que se trata de uma elite que se enquadra claramente no conceito de mimetismo proposto pela teoria do pós-colonialismo. Porém, no caso dos goeses, trata-se de um mimetismo regrado, um mimetismo instigado pelos portugueses, aceite pelos goeses mas controlado por ambos. A proximidade com os estereótipos de portugalidade, propostos pelos portugueses com as regras a que a postura colonial obrigava - suficientemente portugueses, mas sem deixarem de ser indianos - era também controlada pelos goeses, ou seja, a proximidade com os portugueses era conveniente, tinha algumas vantagens sob o ponto de vista económico e social, mas não deveria ultrapassar algumas fronteiras que pusessem em causa a própria goanidade. (SARDO, 2011, p. 118; ênfase minha)

Ao contrário do primeiro romance de língua portuguesa de Goa, as narrativas seguintes trarão ao de cima as ambiguidades 
geradas no âmbito desse mimetismo. Em Retrato do Colonizado, publicado originalmente em finais da década de 1950 e referindo a esfera colonial francesa, Albert Memmi já tinha afirmado que "é este o drama do homem-produto e vítima da colonização: ele quase nunca consegue coincidir consigo mesmo" (2007, p. 181).

Em Os Brahamanes (1866), de Francisco Luís Gomes (1829-1969), para além de a trama do romance se desenrolar no norte da Índia, controlada pelos ingleses (nas narrativas posteriores, Goa será sempre o cenário privilegiado), o português surge-nos com uma espécie de natureza arquétipa, através da figura do missionário Frei Francisco de Santa Catarina, modelo de virtudes liberais e cristãs, exemplo de conduta para o Império britânico (Machado, 2012). Com a construção, ao longo do tempo, da goanidade, ou o que Ângela Barreto Xavier apontou como sendo a invenção de Goa, "as elites de origem local, [...] deixaram de se rever, de certa forma, no estatuto de colonizados", havendo ocorrido uma "transfiguração imaginária do colonizado em colonizador" (2008, p. 26). Repare-se que Francisco Luís Gomes foi até deputado por Goa no Parlamento português, em Lisboa, sendo fulcral para os argumentos que tece na sua obra o direito outorgado aos goeses católicos de acesso à cidadania portugue$\mathrm{sa}^{4}$ o que não acontecia com os indianos sob o jugo britânico. $\mathrm{O}$ romancista fazia parte de uma geração ainda de goeses diretamente exposta, como lembra por sua vez Maria Aurora Couto,

4 Como conta Sandra Ataíde Lobo: "durante a Monarquia Constitucional, a comunidade religiosa se estabeleceu como medida primordial da integração do nativo católico no conceito de cidadão português. Significando esta afirmação que neste discurso é recorrente a ideia de cidadão nativo católico como contemporâneo do cidadão metropolitano e por isso mesmo com autoridade para reivindicar o pleno usufruto dos seus direitos [...]" (2013, p. 112). 
[...] to the ideals of the French Revolution, the Enlightenment and aspirations born with the new Constitution of 1823 created an efflorescence in Goa. It produced a Goan sense of self and an elite society galvanized by its own concerns. [...] They built up collections in their bibliothecas, poured over classics and the work of great minds. They broadened it with Liberalism, learnt to question and to dare with the Encyclopaedists. (CouTO, 2007, p. 88-89)

Noutro romance, vindo a lume após um hiato de trinta anos, são personagens locais que são sobretudo retratadas através da sua adesão à paclocultura. Os reinóis (também soldados, mas ver-se-á que sem o estigma da ameaça, bem pelo contrário) não escapam à língua viperina do autor: percebe-se também um hiato na representação dos portugueses.

Em Jacob e Dulce - scenas da vida indiana (1896/1974), de Francisco João da Costa, estamos diante de uma sátira à dependência da burguesia média católica de Goa a hábitos ocidentais. O contexto sócio-histórico aquando do aparecimento dessa narrativa era bastante oportuno: a seguir à "luta surda entre a elite cristã local e a nobreza crioula" (esta última formada pelos descendentes dos portugueses) que veio atravessando o século, a primeira já tinha começado a dominar "a vida pública do território, [ocupando] a quase totalidade dos quadros, exceção feita aos postos-chaves de governador, de patriarca e de presidente da Relação, sempre reservados a europeus" (THOMAz, 1994, p. 264-267). Vejamos três exemplos de como a referida burguesia nos é apresentada em Jacob e Dulce: 
Aos 22 anos Jacob encetara o estudo de direito.

Era um mancebo guapo, um pouco trapalhão, acanhado diante de senhoras, meticuloso na questão de vestuário. Pouco lhe importava a limpeza do seu corpo, queria as calças à moda em vigor na cidade.

Afligia-se quando o casaco não tivesse o número de botões que marcavam os janotas conceituados e autorizados.

Para ele, o europeu que deparasse na rua, era a personificação da moda, embora o seu fato tivesse sido talhado, no século passado, em Banana.

Para cada vestuário tinha andar especial.

Com simples casaco, movia-se como fadista, mãos em leque impedindo a queda imaginária de punhos imaginários, chapéu à banda, gravata em desordem.

De sobrecasaca ninguém seria capaz de fazê-lo caminhar apressado. Ia pausado, imitando o juiz de direito ou o administrador do concelho, e, como eles, esperava que o saudassem primeiro, e a todos os que o cumprimentavam, retribuía galhardamente com um sorriso de proteção. (Costa, 1974, p. 7)

Nos fins de dezembro, dona Sabina, viúva, mãe da menina Tertuliana e irmã de Salvador Pereira, pediu a este que mandasse a Dulce passar alguns dias consigo.

Era o porcondo ou procondio.

Ignoro a origem do porcondo, e o que propriamente significa. Quando recorri ao dicionário português, só encontrei: porco s. m. quadrúpede. Disse.

Salvador desculpou-se cortesmente alegando incómodos da esposa e lições de piano de Dulce. 
Mas dona Dorotêa e os Dantas acoimaram a recusa de fonice. Diziam eles que Tertuliana estava para casar em maio, a quem também Salvador teria de convidar para sua casa como tio, o que importava despesas, que ele queria evitar.

Contudo dona Sabina tanto insistiu, tanto rogou, tantas vezes alegou a sua qualidade de tia da noiva, que Dulce obteve permissão para ir à casa da mãe de Tertuliana. O porcondo moderno é uma sensaboria. Europeanisou-se. Por via de regra, dá-se uma soirée como qualquer outra, onde a noiva vem e vai com os convivas. Um advogado, célebre pela sua eloquência nas polícias correcionais, faz o brinde da noiva, em que fala do noivo, e diz deste tudo o que não é.

A única coisa que há aí de notável, é a atitude da noiva, que se requebra demais, toma uma desenvoltura imprevista e inesperada, e para ser considerada menina desembaraçada quer responder a tudo e diz disparates, quer ser chistosa e torna-se pedante, assim como acha graça a tudo o que diz o noivo. (Costa, 1974, p. 9)

- É verdade, ainda há bocado, haverá um par de horas, quando o astro do dia ia banhar-se no oceano, deixando após...

- Está poético o amigo, atalhava Miguelinho.... Estimo ouvir-lhe falar com esse rendilhado de frases e com estilo tão facetado...

- É o meu feitio, que diz Celestino? À força de leitura de livros literários, adquiri essa maneira de falar, que é-me natural e de que até um europeu se admirou...

- Eu noto também isso em mim, interrompeu Casimiro, 
quando leio o Camilo; caem-me involuntariamente frases dos lábios, como gotas de orvalho em uma manhã de inverno.

- Não gosto tanto de Camilo Castelo, não escreve mal, é certo, sustentou Celestino com ar superior; algumas páginas que eu perlustrei; ainda ontem estendido no meu divã... não me desagradaram.

- O meu fraco é Júlio, fez Miguelinho.

- Que Júlio? inquiriu Casimiro.

- Júlio Dinis...

- Não é mau... Vi as Pupilas.

Estes três pelintras estavam na mesma tarde na igreja, de chinelos, vendo o casamento de Jacob, e na véspera furtando goiabas no quintal da casa paroquial, donde foram corridos pelo cozinheiro do pároco, deixando um deles no sítio os seus chinelos. (Costa, 1974, p. 106)

A crítica tem visto nessa obra de Francisco João da Costa um certo rechaço à cultura ou aos valores portugueses e, por conseguinte, uma defesa dos costumes locais ou de uma ideia de "indianidade", mas o discurso do autor não deixa de ser complexo. Tal como as suas personagens, Francisco João da Costa pertencia ao universo da paclocultura e o narrador de Jacob e Dulce não se mostrava ele próprio disposto a abandonar certas atitudes do seu meio, como se pode ver a seguir. Repare-se ainda que é o "índio" aquele que vem a ser sobretudo percepcionado como o Outro por um narrador também nativo do território:

[...] é indubitável que a Índia Portuguesa é a pátria do langotim [tanga]: os vestuários ocidentais dificilmente se aclimam aqui, ou se fazem necessários. 
O índio usa deles por convenção, sem nenhuma necessidade; e secretamente os odeia.

Coloque-se o índio, por mais graúdo que seja, por mais civilizado à europeia, independente dos respeitos humanos, fora do alcance dos comentários do vizinho, ele sucessivamente prescinde do casaco, da camisa, das calças, e passa a habitar na cabaia.

Da cabaia para o langotim não vai um passo.

É atavismo francamente acusado.

Tenho observado isto até no índio educado na Europa. Quando regressa a pátria, nos primeiros tempos, dir-se-ia que não pode separar-se das botas, peúgas e gravata. Pouco a pouco S. Excelência esquece-se de vestir estes objectos. Depois chega a vez do casaco e de outras roupas. Deixem-no longe dos comentos, e vão buscá-lo no fim de 4 anos.

Recebe-os de langotim e pedra verde! É atavismo.

Se eu observei os mesmos fenómenos comigo!

Estive uma vez no fundo das Novas Conquistas, no meio de uma povoação vestida de langotim e sem receio de ser surpreendido pelo índio civilizado à europeia e de calções. Ao cabo de uma semana, estava todo dia de ceroulas e camisola, e passei assim o mês inteiro.

Se não enfiei o langotim, não foi por falta de vontade, mas sim pelo medo de que me confundisse com os habitantes da localidade, e pelo receio de que os manducares [cultivadores] me tratassem por: Agá bauddi! [pessoa tosca] Já vi a influência do meio nos europeus reinóis. Tenho-os encontrado de langotim; eram soldados reformados que se deixaram ficar na Índia. 
Deparei outros de robe de chambre sobre o corpo nu: estavam no grau de cabaia. Havia 6 anos que se achavam na Índia; eram magistrados judiciais. Se estes senhores demorassem mais 10 anos no país, suponho que presidiriam as audiências de langotim com cinto de prata. Dantes, os governadores-gerais podiam estar na Índia, como tais 5 anos. Este tempo foi reduzido a 3 anos. Algum ministro, previdente, receou talvez que o general presidisse ao conselho do governo... de langotim, com cinto de ouro, pedra verde com volta de corais, além de lenço vermelho de Damão envolvido à cabeça. (Costa, 1974, p. 47-49)

Ao narrador não lhe cairia bem o vestuário nativo, por gozar de um estatuto social, enquanto católico das elites e aportuguesado, que o regime colonial proporcionava. O que parece estar, realmente, sob a mira das suas admoestações ao longo de Jacob e Dulce é o simples "macaquear" da cultura ocidental, a superficial assimilação por goeses católicos dos ingredientes da portugalidade. Na altura em que escrevia Jacob e Dulce, estimulava-se a ocidentalização "por via da educação e da apropriação dos costumes da modernidade europeia", em especial entre as mulheres das elites, que deviam corresponder a "um modelo de feminilidade" (LoBO, 2013, p. 50), e, na obra, Francisco João da Costa visava também, através da formação dada à personagem Dulce (para se casar), essa educação. Como defende Sandra Ataíde Lobo:

Ao remeter a necessidade de ostentar o domínio do português, da leitura e da escrita e as prendas musicais, como valorativos da mulher no mercado do casamento, 
GIP $^{5}$ omitia o suporte deste modelo, para melhor evidenciar a superficialidade da sua assimilação. Omitia o lugar que no quadro do conceito burguês de família enquanto suporte da moderna sociedade patriarcal vinha sendo preconizado para a mulher, sustentado o seu papel na organização da casa e na reprodução social de valores e padrões comportamentais. É neste âmbito que ganha consistência o discurso em prol da instrução feminina, vista como fundamental à aprendizagem do papel de educadora, de organizadora da economia doméstica e de zeladora do bem-estar da sociedade familiar. [...]. Nesse sentido, a denúncia de GIP aplicava-se ao parcial falhanço desse projecto, quando transformado em convenção social, sedimentada por práticas miméticas das elites subalternas. (2013, p. 52)

Se, por um lado, o autor pareceria, no fundo, não abrir mão da paclocultura, por outro, o que Susana Sardo chamava acima de "mimetismo regrado" reflete-se, no último excerto de Jacob e Dulce reproduzido, na ironia com que fala dos europeus reinóis. O próprio pacló é objeto de uma atitude eurocêntrica, numa clara inversão de papéis, já que se orientaliza, ao adoptar costumes indianos. Não será despiciendo perguntar-se se Francisco João da Costa não estaria ali a tirar partido do largo processo de subalternização dos portugueses por parte dos países europeus hegemónicos, pelo que se considerava ser a cafrealização (adoção dos costumes dos povos tidos por primitivos e selvagens) dos primeiros (SANTOS, 2001, p. 46-64), bastante em sintonia com a

5 Pseudônimo com que Francisco João da Costa publicou Jacob e Dulce - scenas da vida indiana. 
"lenda negra" construída em torno do Império português, associando a procura de indianização ou nativização por algum estrato de lusitanos "à ideia de que os portugueses eram incapazes de se governarem a si mesmos (i. e., de controlarem as suas paixões, de autodisciplinarem a sua natureza) e, por conseguinte, de governarem os outros" (XAvier, 2014, p. 112). O período de Francisco João da Costa é marcado por muitas críticas à administração portuguesa e por uma vontade de autodeterminação. Assim, tal excerto de Jacob e Dulce poderia ilustrar muito bem o que Boaventura de Sousa Santos caracteriza como "espaço de manobra adicional" para o colonizado "tentar a sua auto-representação para além ou fora da representação da sua subalternidade" (2001, p. 27), em virtude, justamente, da possibilidade aberta pelo caráter subalterno ou semiperiférico do colonialismo português face à "norma geral" (p. 26) de colonialismo representada pelo Império britânico e à própria dependência de Portugal à Inglaterra. De qualquer modo, numa certa goanidade - e não "indianidade", por uma elite acabar por preterir costumes locais em vista da sua "Ilustração" (rever Couto acima) - não entram certas atitudes, mesmo se em prática entre os portugueses.

Noutro autor goês de língua portuguesa, José da Silva Coelho (1889-1944), tido pelo herdeiro de Francisco João da Costa, há portugueses e portugueses. Num conto como "O Monserrate", o "mimetismo regrado" declina-se de uma maneira distinta, segundo a própria ação no interior da narrativa: através de um jogo especular entre a burguesia ilustrada e os reinóis, fazendo variar a imagem dos lusitanos consoante a posição destes na sociedade. Um bom português para o protagonista (Bonifácio Monserrate) era aquele cujo estatuto poderia corresponder ao 
seu, o de profissional liberal, ${ }^{6}$ abolindo-se assim, pelo menos ao nível do imaginário (como Ângela Barreto Xavier sugeriu antes quanto à generalidade das elites), a fronteira entre colonizado e colonizador. Um bom português devia ser o seu igual. Esse não era o caso, definitivamente, dos soldados. Vítima da ironia de José da Silva Coelho, tal como ocorre na obra de Francisco João da Costa, a superficialidade das convenções do meio de Goa de que o primeiro também fazia parte ${ }^{7}$. Vejamos o que nos diz o narrador de "O Monserrate":

A outra paixão do Bonifácio eram os bacharéis de Direito pela Universidade de Coimbra. Não os indianos formados na Metrópole - por estes nutria uma secreta inveja e tinha-lhes raiva -, mas os bacharéis europeus. E, ampliando a sua paixão, começou a adorar todos os europeus civis, porque aos militares, embora oficiais de engenharia, taxava-os de tarimbeiros e não lhes ligava importância. E não passava europeu algum à paisana, conhecido ou desconhecido, sem que o Bonifácio Monserrate o cumprimentasse logo, com rasgadas barretadas, e procurasse por todos os meios aproximar-se dele e ser-lhe agradável.

Ora, sucedeu que Cipriano Cantina, soldado de infantaria europeia, que estava em diligência nas Obras Pú-

6 Segundo Thomaz (1994, p. 268): "a élite goesa revelou sempre uma grande predilecção pelas profissões liberais, particularmente as de médico e advogado". Estas profissões gozavam de bastante status, revelando-se aí, provavelmente, a mesma "influência do $b a$ charelismo que na mesma época era dominante em Portugal como no Brasil, países pouco atingidos pela revolução industrial e portanto sem uma verdadeira burguesia capaz de substituir os seus valores pelos da pseudo-burguesia de letrados (saída, em grande parte, dos proprietários fundiários) que implantara o liberalismo e dominava a cena política". 7 Compare-se, aliás, o primeiro excerto reproduzido do segundo autor com os do primeiro a seguir, no que diz respeito aos sinais exteriores e às profissões. 
blicas, andasse à paisana enquanto olhava pelos consertos que se estavam fazendo na aldeia de Bonifácio. Este, apesar de o Cantina estar muito queimado pelo sol e mais escuro que um cantoneiro, conheceu pela fala que era europeu e, supondo-o civil, imaginou-o logo engenheiro. Daí a fazê-lo bacharel em Matemática não ia um passo, e logo o Bonifácio começou a fazer rasgados cumprimentos ao passar e repassar por Cipriano Cantina, que este ficou muito admirado de uma tão subida consideração por parte de um ilustre advogado. (Coelho, 1979, p. 159-160)

Posteriormente, foram ambos convidados a uma soirée de casamento. Cipriano Cantina, incomodado com a "sobrecasaca velhíssima" que arranjara, hesitava em entrar na casa onde decorria o serão. Bonifácio Monserrate, depois de se dar conta, pela janela, da chegada do primeiro, vai ter com ele à rua. Cantina pede a Monserrate a casaca deste por uns instantes, o tempo apenas de ir cumprimentar os noivos, para não passar por um indelicado. O goês acede ao pedido, mas o português, entusiasmado com a namorada que lá encontra, fica a dançar durante a noite toda, deixando a casa só de madrugada. Nesse ínterim, Monserrate

[... pela primeira vez duvidou da autenticidade do bacharel em Matemática e, como a noite esfriava, envergou a sobrecasaca do Cipriano Cantina que até então trouxera, respeitosamente, no braço. Mas, sentindo o cheiro a bafio e a coisas velhas a que tresandava a velhíssima sobrecasaca, percebeu o logro em que caíra: nunca uma pessoa que trazia uma sobrecasaca daquelas podia ser bacharel. [...] 
Hoje, quando vê um europeu, não o cumprimenta logo, nem mesmo de longe, com uma rasgada barretada: espera, prudentemente, que se aproxime, e depois de minuciosamente o observar, faz-lhe um vagaroso e respeitoso cumprimento. (Coelho, 1979, p. 161)

Na ficção goesa de língua portuguesa passada a integração de Goa na União Indiana em 1961, é através ainda das elites mimetizadas, mas também de setores marginalizados da população, que a percepção dos paclé pelos goeses nos é sugerida.

No conto "A subvenção", da coletânea Monção (1963), Vimala Devi (nascida em 1936 e vivendo há muitas décadas em Barcelona) fustiga certas idiossincrasias dos descendentes de portugueses, na primeira metade do século XX. Por causa de uma subvenção colonial que lhes vem a ser oferecida, Eucaristino, um oficial da Fazenda, entra em casa de forma diferente dos outros dias, a gritar para a mulher e os filhos que daí em diante tudo iria mudar, os utensílios domésticos seriam substituídos por aparelhos ocidentais, as apas (bolo de farinha assado em barro) por pães e o caril por bacalhau, já que agora eram considerados paclé: "nós agora somos civilizados, não somos como goeses" (Devi, 2003, p. 125). No romance O último olhar de Manú Miranda (2000), de Orlando da Costa (instalado em Portugal desde os 18 anos de idade e lá falecido), Ubaldino Antão, da elite autóctone, revolta-se com "a obsessão de uma camada culta da sociedade querer exibir a sua erudição e enaltecer, no seio das suas próprias famílias, figuras da cultura europeia”, para finalmente concluir com desgosto serem os goeses "uma espécie de macacos de imitação", uma prova disto residindo no "costume de uns quantos 
brâmanes ${ }^{8}$, que na ânsia de demonstrar a sua familiaridade com tudo quanto fosse europeu, consultavam em almanaques franceses nomes sonantes para de entre eles escolherem os que mais lhes agradavam" (Costa, 2000, p. 248). Em Casa Grande e outras recordações de um velho goês (2008), de Leopoldo da Rocha (nascido em 1932), a mãe de Bal, o protagonista, é marcada pela "mania de ostentação balofa do estilo português, embora ela, em família e entre os seus membros, falasse só o concani” (RochA, 2008, p. 86). Mais: "detestava tudo que não fosse do figurino colonial" (RochA, 2008, p. 86). O português é o modelo a seguir a qualquer custo para muitas personagens, enquanto outras e mesmos os narradores não são nada simpáticos para com os portugueses: veja-se ainda a narrativa de Leopoldo da Rocha, na qual, apesar de "pessoa inapta", o "director espiritual" do seminário por onde passara o protagonista era "o único português europeu de confiança do estado" (2008, p. 124). Na fase pós-colonial, no entanto, já não se trata mais para os escritores de controlar "os estereótipos da portugalidade" (cf. SARDO, 2011, no início): compreende-se que é a própria ideia de goanidade que é controlada, pela consciência dos autores quanto às ambiguidades que encerra e à difícil síntese a que se procura chegar. A distância para com a realidade objetiva da presença colonial em Goa o terá, sem dúvida, estimulado.

Se, em Jacob e Dulce, de Francisco João da Costa, no período oitocentista, era sinal de prestígio para as moças das elites dançar com os paclé, no conto novecentista "Esperança", de Vimala Devi, também incluído em Monção, algo semelhante significava uma ignomínia. Conta-nos o primeiro:

8 A casta mais alta no sistema hierárquico-social da Índia, tanto na esfera hindu como católica. 
D. Tatarícia queria que a filha sobrelevasse a todas as donzelas da cidade de Breda, e quando, na igreja, por ocasião do recebimento, viu a toilette pomposa de Tertuliana, perdeu a cabeça. Seria um escândalo que sua filha, que era da capital, que assistira às soirées do club, que uma vez dançou com um guarda-marinha europeu, e duas vezes com o capitão do porto (europeu) e mais uma vez com um alferes (europeu), fosse vencida por uma provinciana, que nunca dançou com um europeu!... (Costa, 1974, p. 112)

No segundo, as jovens goesas, se andassem "a dançar com os paclé", seriam mal faladas, tratadas por "malucas" (DEvi, 2003, p. 62.). Roberto é cioso da reputação das irmãs:

"Só não gosto nada que vocês dancem com os paclé. Porque não dançam só com os nossos rapazes? Os paclé não têm moral e dão mau nome às raparigas, sabes bem!" "Nisso tens razão", respondeu Mitzi, muito séria. "Nossos rapazes são tão diferentes dos paclé. Tu achas-me capaz de casar com um deles? Além disso, eles aqui fazem figura, mas quando estão na Europa são uns pelintras. E estúpidos, não reparaste ainda? Nossos rapazes são muito diferentes e quando casam é para toda a vida. Eles mudam de mulher como quem muda de camisa... Preferia casar com um sudra ${ }^{9}$ do que com um pacló! (Devi, 2003, p. 63-64)

9 A casta mais baixa, tanto na esfera hindu como católica. 
No que concerne à paclina (portuguesa), a aversão, em certos casos, podia ser a mesma, e não só na comunidade católica, mas também na comunidade hindu. No seu trabalho de campo, inclusive, o geógrafo português Orlando Ribeiro tinha reparado o que "dizem as mães goesas: 'Casou com uma paclina (=europeia) já está o meu filho perdido"' (RIBEIRO, 1999, p. 79-80). Em "Fidelidade", outro conto de Vimala Devi, um hindu que fora para Portugal tirar o curso universitário e deixara a mulher na Índia, envolve-se sexualmente com uma portuguesa, retratada pela autora como sobejamente frívola, desprezando tudo quanto diz respeito aos costumes da família do amante e incorrendo numa sistemática infantilização desse Outro oriental que quer manter como companheiro (Devi, 2003, p. 87-90). No romance O último olhar de Manú Miranda, se, por um lado, nascer com a pele clara das paclinas, é sinal de beleza e granjeia status social às goesas, por outro, consoante a situação e o meio, estas podem passar a vida sendo apodadas de paclinas não por respeito e admiração, mas por pura troça. Imagine-se, então, o caso das descendentes dos portugueses, como Martha Catarina, "mulher não [...] indicada" (Costa, 2000, p. 125) para Emílio, membro de uma das elites autóctones.

Noutro romance de Orlando da Costa, O Signo da Ira, mencionado na introdução, os portugueses são mesmo os soldados, na sua maioria. A classe agrícola dos curumbins é explorada tanto pelos paclé quanto por uma das elites locais, os batcarás, donos de terras, sendo os curumbins os seus manducares, cultivadores. É ali posta em cena a permanente tensão entre esses desvalidos da sorte e os soldados expedicionários portugueses, considerados maus e tidos até por violadores, uns "malditos demónios", verdadeiros "inimigo[s]" (Costa, 1996, p. 16 e 19). 
- Sabe, avô... - o seu olhar desviou-se, deixando suspenso um véu de malícia e ingenuidade. - No outro dia esteve aqui um pacló, um desses soldados que agora passam pela estrada...

- O quê? - admirou-se Jaqui. - Onde? Aqui?

- Sim, aqui mesmo, no povoado. Eu estava junto do poço e ele aproximou-se... [...]

- E o que queria ele? - a voz do velho erguia-se trémula sob o peso da ansiedade. Não ouvira já ele histórias estranhas e terríveis sobre esses homens? Talvez fossem inventadas, talvez simples mentiras, mas ele estava com medo, com medo, porque acreditava nelas. - E o que queria? - Água... - respondeu a rapariga. - Tirou-me o calão da cabeça... e bebeu. E eu fugi, cheia de medo. [...]

- Não quero que você lhe apareça mais, ouviu? - berrou Jaqui, erguendo a mão numa ameaça. Natél compreendeu que aquela mão se erguia não contra ela, mas contra o estranho de quem ele acabara de ouvir falar. - Lá porque é soldado julgará que tudo isto é seu?... - na sua voz irritada a raiva abriu um sulco. E Natél estremeceu. (CosTa, 1996, p. 54-55)

Para esta classe, ao contrário das outras, os portugueses seriam realmente "gente estrangeira, não são como nós" (CosTA, 1996, p. 28; ênfase minha). No caso das elites, das quais saíram os próprios escritores aqui abordados, estas são e não são como os portugueses, enredadas para todo o sempre na teia da paclocultura. Uma afirmação acerca dessa condição por parte de outro escritor saído também desse estrato social (mas autor de língua inglesa), João da Veiga Coutinho, constituiria um axioma perfeito do 
"mimetismo regrado". Afirma, pela boca do Padre Gabriel Saldanha (1853-1930), que escreveu uma História de Goa (1925/1926) e com quem imagina uma conversa: "sei que nós não somos 'os portugueses', mas somos 'portugueses"' (Coutinho, 2000, p. 36).

Isso não quer dizer que a cumplicidade das elites autóctones com o poder colonial ao longo do tempo autorize afirmar que "a assimetria e a violência [não tenham organizado], desde os primeiros momentos, a presença política portuguesa" em Goa: "a redução da distância entre estes dois grupos" no imaginário imperial e em estruturas do sistema não impediu que "a distância, a diferença e a hierarquia [permanecessem] até ao fim" (XAVier, 2008, p. 449). Daí o ressentimento que pode parecer mover muitas vezes tanto o discurso dos escritores quanto o de muitas das suas personagens, bem como a tentativa de expressão de uma individualidade que ultrapasse os limites de um simples mimetismo colonial?

\section{Referências}

Coelho, José da Silva. O Monserrate. Boletim do Instituto Menezes Bragança, n. 124, p. 158-161, 1979.

Costa, Francisco João da. Jacob e Dulce: scenas da vida indiana. 3. ed. Pangim: Tipografia Sadananda, 1974.

Costa, Orlando da. O último olhar de Manú Miranda. Lisboa: Âncora, 2000.

. O Signo da Ira. 4. ed. Lisboa: Temas da Actualidade, 1996. 
CoutinHo, João da Veiga. Uma espécie de ausência: viver na sombra da história. Versão portuguesa revista pelo autor. Lisboa: Cotovia/Fundação Oriente, 2000.

Couto, Maria Aurora. Goa: história de uma filha. Tradução de Vasco Pimentel. Goa: Fundação Oriente, 2012. In the land of Brahama. In: FigueIRA, Maria Inês; Noronha, Oscar de (Org.). Episódio Oriental: readings in Indo-Portuguese Literature. Pangim: Fundação Oriente/Third Millennium, 2007. p. 88-102.

Dalgado, Sebastião Rodolfo. Glossário luso-asiático. v. 2. Coimbra: Imprensa da Universidade, 1921.

Devi, Vimala. Monção. 2. ed. aumentada. Lisboa: Escritor, 2003. Fernandes, Agostinho. Bodki. Porto: Edição do Autor, 1962.

Loвo, Sandra Ataíde. O desassossego goês: cultura e política em Goa do liberalismo ao Acto Colonial. Tese (Doutorado em História e Teoria das Ideias) - Universidade Nova de Lisboa, Lisboa, 2013.

Machado, Everton V. Introduction. In: Gomes, Francisco Luís. Les Brahmanes. Tradução de L. de Claranges-Lucotte. Edição de Everton V. Machado. Paris: Classiques Garnier, 2012. p. 7-71.

Memmi, Albert. Retrato do colonizado precedido de Retrato do Colonizador. Tradução de Marcelo Jacques de Moraes. Rio de Janeiro: Civilização Brasileira, 2007.

Mendes, António Lopes. A India portugueza: breve descripção das possessões portuguezas na Asia. v. 2. Lisboa: Imprensa Nacional, 1886. 
Ribeiro, Orlando. Goa em 1956: Relatório ao governo. Organização de Suzanne Daveau. Lisboa: Comissão Nacional para as Comemorações dos Descobrimentos Portugueses, 1999.

Rocha, Leopoldo da. Casa Grande e outras recordações de um velho goês. Lisboa: Vega, 2008.

Santos, Boaventura de Sousa. Entre Próspero e Caliban: colonialismo, pós-colonialismo e inter-identidade. In: RAMALHO, Maria Irene; RibeIro, António Sousa (Org.). Entre ser e estar: raízes, percursos e discursos da identidade. Porto: Afrontamento, 2001. p. 23-85.

SARdo, Susana. Guerras de jasmim e mogarim: música, identidade e emoções em Goa. Lisboa: Texto, 2011.

Thomaz, Luís Filipe F. R. De Ceuta a Timor. 2. ed. Lisboa: Difel, 1994.

Xavier, Ângela Barreto. Parecem indianos na cor e na feição:

a "lenda negra" e a indianização dos portugueses. Etnográfica, n.18, v. 1, p. 111-133, 2014. Disponível em: http://etnografica. revues.org/3372. Acesso em: 14 dez. 2014.

. A invenção de Goa: poder imperial e conversões culturais nos séculos XVI e XVII. Lisboa: Imprensa de Ciências Sociais, 2008.

MACHAdo, Everton V. Os paclé (portugueses) em narrativas goesas de língua portuguesa ou o "mimetismo regrado". In: Simas, Monica (Org.). Estudos sobre Macau e outros orientes. São Paulo: Paulistana, 2017. p. 201-223. 


\section{A carnavalização hiperbólica da Macau Setecentista num soneto de Bocage (c.1789) em prol da figura do ouvidor Lázaro da Silveira Ferreira ${ }^{1}$}

Rogério Miguel PUGA

O presente estudo analisa a representação sócio-histórica de Macau no soneto "Um governo sem mando, um bispo tal", de Manuel Maria Barbosa du Bocage (1765-1805), detendo-se na estada do poeta no enclave, no contexto de produção e nos objectivos políticos do processo de carnavalização que caracteriza a composição poética, ocupando-se também forçosamente da relação entre o mundo possível textualizado por Bocage de forma realista e os referentes extra-textuais para os quais o soneto remete. Como já afirmámos anteriormente (PugA, 2009a, p. 31-32), o conceito de literatura - enquanto fenómeno social e construção

\footnotetext{
1 Artigo já publicado no n. 49 da Revista de Cultura (Instituto Cultural de Macau, Macau), em 2015, p. 6-22.

2 Doutorado em Estudos Anglo-Portugueses (2007), foi Professor Auxiliar na Universidade de Macau (2007-2009) e é Investigador Auxiliar na FCSH/Nova e Professor Adjunto Convidado no Instituto Politécnico de Lisboa; rogerio_puga@hotmail.com
} 
ou poiesis histórico-antropológica,$-{ }^{3}$ bem como as complexas relações entre a história e a literatura, e nomeadamente a poesia, ${ }^{4}$ são cada vez mais estudados de forma interdisciplinar. ${ }^{5}$ Como veremos, o poema de que nos ocupamos carnavaliza e caracteriza de forma hiperbólica o contexto histórico da Macau do final do século XVIII (o tempo da escrita), sendo actualmente um repositório textual desse período histórico da urbe para leitores que têm assim acesso a essa representação subjectiva e simultaneamente politica e literária. Maria de Fátima Marinho estuda as relações entre o passado e a sua transposição para a escrita, afirmando que estas são "sempre difíceis mas também sempre sedutoras", sobretudo devido ao facto de a história ter tomado consciência da impossibilidade de produzir um discurso único e definitivo sobre acontecimentos reais e de o romance não ser um género estável nem coerente. ${ }^{6}$ Maria Alzira Seixo, ao abordar a questão, resume essas relações a partir de quatro perspectivas de trabalho, a saber: 1) através da história literária (captação do sentido evolutivo dos modos de escrever, ler, ensinar e difundir a literatura); 2) através da interdisciplinaridade que convoca o conhecimento da história e da literatura, entendendo os estudos literários como intersecção do espaço das ciências da linguagem e dos estudos de estética com o das ciências históricas, ou seja, o estudo do relacionamento entre a poética (cenas de efabulação) e a historicidade (cenas de convocação histórica); 3) através

3 Vide Manuel Gusmão (2001, p. 181-224).

4 Roundell Palmer (1852), Emery Neff (1961) e Paul A. Bové (2008).

5 Sobre a relação entre literatura e história, vejam-se Lionel Gossman (1990, p. 227-256); Dirce Côrtes Riedel (1998); Luiz Eugénio Véscio e Pedro Brum (1999); David Der-wei Wang (2004, p. 1-40, 183-223); Maria de Fátima Marinho e Francisco Topa (2004), e Maria de Fátima Marinho (2005).

6 Maria de Fátima Marinho (2005, p. 9-20). 
do estudo da história em geral entendida como memória de um passado humano colectivo passível de ser reconstituída e alterada verbalmente e, portanto, tema ou motivo de textualização literária, e 4) através da acepção da história como movimento accional de um texto, como intrincado de problemas e actuações, e como intriga ou efabulação, pois contar uma história é remeter para situações idênticas que se reportam a um mundo "real" (circunstancial) e ao imaginário da memória comum. ${ }^{7}$ Para o estudo do soneto "Um governo sem mando, um bispo tal", de Bocage, interessam-nos sobretudo estas três últimas relações entre literatura e história, ou seja a história quer como efabulação quer como estratégia, tema ou motivo literário. Analisaremos assim de que forma a literatura e a história se podem questionar mutuamente no poema, de que modo a história se assume ou pode ser implicada ou convocada como elemento estruturante do poema e quais os limites da representação da ideologia e da história na literatura em geral. Só conhecendo a história da Macau Setecentista que o poema tenta caracterizar com base em fortes juízos de valor poderemos estudar esse texto em profundidade e descodificá-lo à luz da realidade extra-textual para que este remete.

A biografia de Manuel Maria Barbosa du Bocage é já bastante conhecida, bastando-nos reter apenas alguns factos para a compreensão da sua viagem-fuga até Macau, que lhe permite carnavalizar a urbe no referido soneto. A vertente carnavalesca da sua obra está presente inclusive num auto-retrato em que prevalece a auto-caricaturização algo dionisíaca:

7 Síntese elaborada a partir de Maria Alzira Seixo (2004, p. 231-241). 
Magro, de olhos azuis, carão moreno,

Bem servido de pés, meão na altura,

Triste de facha, o mesmo de figura,

Nariz alto no meio, e não pequeno;

Incapaz de assistir num só terreno,

Mais propenso ao furor do que à ternura;

Bebendo em níveas mãos, por taça escura,

De zelos infernais letal veneno;

Devoto incensador de mil deidades

(Digo, de moças mil) num só momento,

E somente no altar amando os frades,

Eis Bocage, em quem luz algum talento;

Saíram dele mesmo estas verdades,

Num dia em que se achou mais pachorrento. (1969, p. 3)

O carnavalesco (ou carnavalizado) mundo bocageano foi também descrito pelo excêntrico viajante britânico William Beckford após um encontro com o poeta luso entre 1793 e 1795. Em Italy, with Sketches of Spain and Portugal, o escritor descreve Bocage através de sugestivos adjectivos:

[...] the queerest, but perhaps, the most original of God's poetical creatures. He happened to be in one of those eccentric, lively moods, which, like sunshine in the depth of the winter, come on when least expected. A thousand quaint conceits, a thousand flashes of wild merriment, a thousand satirical darts shot from him, and we were all convulsed with laughter...Indeed, this strange and versatile character may be said to possess the true wand of enchantment, which, at the will of its master, either animates or petrifies. (1834, p. 204-205) 
Essa mesma imagem continua a ecoar na literatura portuguesa, como podemos verificar através de, por exemplo, o título do romance de Luís Rosa, Bocage, a Vida Apaixonada de um Genial Libertino (2006), e do anedotário popular que é, embora injustamente, associado a Bocage em Portugal e no Brasil.

\section{A viagem rumo ao Oriente}

Em 1786 o oficial da Marinha Bocage viaja para Goa no Nossa Senhora da Vida, Santo António e Madalena, visitando o Rio de Janeiro (junho) e Moçambique (setembro). O poeta chega a Goa no final de Outubro desse ano e torna-se amigo do juiz-poeta Sebastião José Ferreira Barroco (1777-1802), ajudando a controlar a chamada Conspiração dos Pintos (1787). ${ }^{8}$ Bocage descreve a capital do império português asiático e, mais tarde, Macau, como cidades decadentes. Goa encontrava-se então em ruínas, imagem que em 1851 também Sir Richard Francis Burton (1821-1890)9 enfatizaria, sendo esse mesmo simbólico e alegó-

8 Teófilo Braga (1902, p. 55-57).

9 Conforme Richard Francis Burton descreve em Goa and the Blue Mountains or Six Months of Sick Leave (1851) de Pangim, o viajante vitoriano parte para Velha Goa e descreve-a "as it was" no capítulo terceiro - através de intertextos históricos que convoca para o tecido arqueológico do seu próprio texto -, e "as it is" no capítulo quarto, textualizando o passado de monumentos imperiais então em ruínas. A velha e isolada Goa é apresentada como uma cidade cronotópica, um espaço histórico palimpséstico onde ser descobrem diversas camadas escondidas ou esbatidas pelo passado e reveladas por antigos relatos de viagem. Os diferentes edifícios simbolizam os diversos tipos de poder, o palácio remete para o poder religioso e político, a alfândega para o económico e comercial e para os cofres centrais da metrópole, enquanto as estátuas de Afonso de Albuquerque e o arco dos vice-reis (60) remetem para os poderes administrativo e militar, estando muitos desses monumentos, alegorias do poder colonial português, ao abandono (61). O choque do encontro-confronto de Burton com a realidade Outra e com o espectáculo duplo da alteridade é metaforizado através da arquitectura, como revela a expressão: "monotony of 
rico espaço colonial português apresentado de forma negativa pela voz crítica do sujeito poético, como um "ermo":

Das terras a pior tu és, ó Goa,

Tu pareces mais ermo, que cidade;

Mas alojas em ti maior vaidade que Londres, que Paris, ou que Lisboa. ${ }^{10}$

Em fevereiro de 1789, o poeta boémio é promovido a tenente da Infantaria e em março é transferido para Damão, onde chega a 6 de abril. Dois dias depois, acompanhado pelo alferes Manuel José Dióniso, Bocage deserta. Os dois fugitivos deslocam-se para Surrate e daí viajam, talvez a bordo de uma embarcação britânica, para Macau. Desconhecem-se os motivos da viagem para o Sul da China, no entanto o poeta cantou aventuras na província de Cantão - espaço alargado que poderá, no entanto, remeter metonimicamente para Macau - e perigosas deambulações que, no entanto, poderão ser estratégias literárias do processo de auto-glorificação, na senda de viagens picarescas (lendárias ou reais), como as de Camões ou Fernão Mendes Pinto e

ruins" (63). Essas ruínas católicas decerto recordariam o leitor britânico das ruínas católicas no seu próprio país, fruto da Reforma Protestante de Henrique VIII trezentos anos antes. As ruínas de Goa, remetendo para as ruínas de abadias e igrejas católicas extintas no século XVI por toda a Inglaterra, sugeririam o aparecimento de uma nova ordem, e talvez seja essa a mensagem subliminar do texto quando Burton afirma: que parece que "a curse has fallen upon Old Goa where the Inquisitio ruled" (62). Sobre as ruínas católicas de Velha Goa nascerá uma nova ordem protestante, vinda da Índia britânica. A Goa empobrecida e ofuscada pelas cidades portuárias britânicas na Índia, como Bombaim, já não é visitada por mercadores importantes, continua a tolerar a convivência de diferentes religiões e foi esquecida por Roma. O exercício da intertextualidade, como vimos, serve assim o propósito de enfatizar a velha glória de Goa, agora desaparecida, tal como a pujança do império luso, ao contrário do poderoso império britânico.

10 Vide Ethel M. Pope (1937, p. 180), Gomes Monteiro (1943, p. 63), e o romance de Luís Rosa, Bocage, a Vida Apaixonada de um Genial Libertino (2006, p. 102). 
que exigem o confronto com os elementos naturais, como também Os Lusíadas demonstram através de episódios e temas como os do Fogo de Santelmo e da tempestade. Bocage 'narra' da seguinte forma as suas viagens:

\section{Por bárbaros sertões gemi vagante}

Até que os mares da longínqua China.

Fui por bravos tufões arrebatado. ${ }^{11}$

O poeta auto-caracteriza-se assim como um escritor picaresco no Oriente de cariz lusófono, na senda de Mendes Pinto, que antecede Wenceslau de Morais e Camilo Pessanha. Na elegia de Bocage à morte do príncipe D. José (m. 11-09-1788), lemos ainda:

Triste povo! E mais mísero eu, que habito

No remoto Cantão, donde, Ulisseia,

Não pode a ti voar meu débil grito!

Misérrimo de mim que em terra alheia. ${ }^{12}$

O poeta desertor deverá ter residido em Macau entre setembro-outubro de 1789 e março de 1790, uma cidade governada pelos mercadores do Senado, ${ }^{13}$ pelo Ouvidor e pelo Governador, bem como pelo poder religioso, todos eles directa ou indirectamente visados no poema de que nos ocuparemos. Em Macau, Bocage tornou-se amigo do capitão-geral/governador Lázaro da Silva Ferreira, que juntamente com outro governador interino,

11 Teófilo Braga, (1902, p. 73).

12 Vejam-se Teófilo Braga (1902, p. 74) e Mário Domingues (1962, p. 149).

13 Arquivo Histórico Ultramarino (AHU), caixa 6, doc. 35. 
o major Manuel da Costa Ferreira, comandante do Presídio, substituíra Francisco Xavier de Mendonça Corte Real, em 16 de Julho de 1789 (após a morte deste último), governando até 29 de Julho do ano seguinte, altura em que Vasco Luís Carneiro de Sousa Faro se torna governador. O ouvidor-governador Lázaro da Silva Ferreira não acusa o poeta de desertar de Damão e inclusive tê-lo-á auxiliado a regressar a Lisboa, onde Bocage chega em Agosto de 1790, agradecendo ao governador através de um poema, uma prática que aliás se estende a outros seus benfeitores do enclave. O escritor teria sido apoiado em Macau e no regresso a Portugal também por Maria Joaquina de Saldanha Noronha e Meneses, ${ }^{14}$ a quem dedica a ode "O Adeus", ${ }^{15}$ redigida no final de 1789 e que elogia a beleza quer da "piedosa e magnânima" (TeixeIrA, 1997, p. 279) senhora "Marília" que "enche $[. .$.$] de glória a fertile China", quer das "lindas filhas"$ dela (TeixeIRA, 1997, p. 279), pedindo-lhe que o ajude a voltar para Portugal. O poeta escreve ainda outra ode dedicada a Maria de Guadalupe Topete Ulhoa Garfim, residente de Macau que é descrita como "semi-deusa gentil" (TeixeirA, 1997, p. 281). Como prova a 'Rua do Bocage' no território, o poeta viajante faz ainda hoje parte da memória colectiva de Macau.

Elmano Sadino instalou-se temporariamente em Macau e regressou à Europa também com o apoio do comerciante Joaquim Pereira de Almeida, que chegara ao território por volta de 1787, chamando-lhe o poeta "meu benfeitor, meu caro ami-

14 Casou em 1774 com Bernardo Aleixo de Lemos Faria, governador de Macau (17831788) e teve duas filhas, Ana Isabel de Lemos Saldanha e Mariana Xavier de Lemos Saldanha.

15 Bocage (2005); ode originalmente publicada em Noites de Évora (1897) e posteriormente no Jornal de Letras, Artes e Ideias (04-17 janeiro 2006, p. 19). Veja-se Adelto Gonçalves (2003, p. 147,458$)$. 
go" (GonçALVEs, 2003, p. 147) numa elegia que lhe oferece por ocasião da morte de seu pai, escrita em Lisboa, quando ambos já estavam em Portugal. Joaquim Almeida foi sobrecarga da nau Marquês de Angeja e talvez Bocage tivesse deixado Macau com destino a Lisboa nessa embarcação no início de Janeiro de 1790. No soneto "Aos Amigos", publicado em Improvisos de Bocage na sua mui Perigosa Enfermidade, o poeta caracteriza Almeida como "humano" (GonçALVES, 2003, p. 147), sendo o homenageado também amigo do já referido governador interino, ouvidor e juiz-administrador da alfândega Lázaro da Silva Ferreira.

O juiz-governador Silva Ferreira tomou posse na Ouvidoria de Macau quando esta foi restabelecida em 1785 e, como já referimos, beneficiou o poeta quando ele chegou ao território como desertor, ignorando esse crime (GonçAlves, 2003, p. 142-147). O poeta dedicou ao juiz a ode sáfica "A Gratidão", na qual confessa: "Tudo a ti devo, ó benfeitor, ó grande.../Tudo te devo: a gratidão não sofre/Que teus favores generosos cale...//Ó céus! Ó fados! Conservai Ferreira;/São necessários os heróis no mundo:/E tu ferrolha os porcelosos monstros,/Éolo amigo" (TeixeIra, 1997, p. 282-283). Após tomar posse, o juiz repôs a ordem nas finanças quer da administração pública da cidade, quer da Santa Casa da Misericórdia, gerando assim inimigos locais que desviavam verbas para causas pessoais e de grupos de interesse. No Verão de 1787, já o Senado e o governador Sousa Faro haviam tentado, em vão, junto de Goa, acusar o juiz de conflitos entre portugueses e chineses e destituí-lo, ${ }^{16}$ mas Ferreira apenas foi substituído como juiz, por António Pereira dos Santos, a 15

16 AHU, caixa 17, docs. 3 e 68; caixa 18, docs. 21 e 34; caixa 19, docs. 7 e 34; caixa 20, docs. 10-11; caixa 21, doc. 5; os parágrafos 30-37 das "Instruções", p. 13-16 e António Martins do Vale (1997, p. 16-17). 
de Maio de $1797 .{ }^{17} \mathrm{O}$ magistrado fora nomeado por um período de três anos, entre 1787 e 1789, e já conhecia as especificidades de Macau, pois quando da Instrução de 1783 fora incumbido de examinar os cofres públicos, estabelecer a alfândega e ajudar a instalar o Seminário de São José. Em 1787, o juiz não foi bem recebido pela população devido aos interesses instalados na urbe, pois ao acumular vários outros cargos (juiz dos órfãos, juiz de alfândega, provedor dos defuntos e dos ausentes e contador da comarca) retirava poder e espaço de manobra aos senadores que compunham o Leal Senado. O ouvidor e o governador são ainda estrategicamente culpados pelo Senado de causarem conflitos entre os portugueses e os chineses (1787), ${ }^{18}$ acusando o governador Sousa e Faro o ouvidor Silva Ferreira de corrupção e favorecimento de estrangeiros (1792, 1795, 1789). ${ }^{19}$ Já em 1783, o próprio Martinho de Melo e Castro descreve o Senado como um órgão composto "na sua maior parte de Degredados, que ali se refugiaram, ou de outros similhantes a eles, todos ignorantíssimos em matérias de Governo, e sem outras vistas mais, que as de procurarem a sua fortuna" (Melo E Castro, 1988, p. 11). Como veremos, o poema de que nos ocupamos ecoa quer essa imagem negativa sobre os (oportunistas) moradores de Macau - que era então repetida por parte do discurso político de Goa e de Lisboa (Martinho de Melo e Castro), e até de Macau [ouvidor Lázaro da Silva Ferreira, governadores Bernardo Aleixo de Faria (17831788) e Vasco Luís Sousa e Faro (1790-1793)], sobretudo a partir de 1770 - , quer os referidos jogos de interesses locais e a submissão dos moradores perante as autoridades chinesas devido a

17 AHU, caixa 18, docs. 21, 44.

18 AHU, caixa 18, docs. 21, 34, caixa 19, doc. 7, caixa 21, doc. 5 .

19 AHU, caixa 19, doc. 34, caixa 20, docs. 10-11, caixa 21, doc. 5 . 
interesses locais (lucros). ${ }^{20}$ Torna-se assim importante atentar no uso da história como temática literária e ferramenta ideológica no texto bocageano que transcrevemos de seguida.

\section{O Soneto}

Um governo sem mando, um bispo tal, A

De freiras virtuosas um covil B

Três conventos de frades, cinco mil B

Nhon's e chinas cristãos, que obram mui mal; A

Uma Sé que hoje existe tal e qual A

Com catorze prebendados sem ceitil; B

Muita pobreza, muita mulher vil, B

Cem portugueses, tudo em um curral; $\quad$ A

Seis Fortes, cem soldados e um tambor, C

Três Freguesias, cujo ornato é pau, D

Um Vigário Geral, sem promotor; C

Dois colégios, e um deles muito mau, D

Um Senado que a tudo é superior; C

É quanto Portugal tem em Macau. ${ }^{21}$ D

20 Veja-se António Martins do Vale (1997, p. xvi-xix).

21 Bocage, Obra Completa, vol. 1: Sonetos, edição de Daniel Pires, Porto: Edições Caixotim, 2004, soneto n. 196. A mais recente edição da Obra Completa é da responsabilidade de Daniel Pires, presidente do Centro de Estudos Bocageanos, de Setúbal e é publicada pela Edições Caixotim (Porto): vol. 1: Sonetos (2004), vol. 2: Cantatas, canções, idílios, epístolas, odes e cantos (2005), vol. 3: Apólogos ou fábulas morais, epigramas, poesia sobre mote, poesia anacreôntica, endechas, elegias, epicédios (2007), vol. 4: Sátiras, madrigal, poesias várias, epitáfios, improvisos, elogios dramáticos, elogios à família Real, dramas, prólogos de peças teatrais, fragmentos dramáticos, fragmentos, anexos (2007), vol. 7: 
Como revela a leitura do soneto 'político', o sujeito poético serve-se da enumeração, da adjectivação e de substantivos com carga negativa ("covil", "mal", pobreza", "vil", "curral", "mau"), bem como da aliteração (sibilante) para criticar, de forma hiperbólica, o ambiente social, religioso e político da urbe, detendo-se apenas nos aspectos negativos. O queixume acentua a imagem algo triste de um território decadente e abandonado por Lisboa. Trata-se de um crítica e de um possível pedido de ajuda para Macau, uma quase certidão de óbito através do exercício da carnavalização, sobrepondo-se claramente o projecto ideológico/político ao valor estético do poema, que é claramente reduzido. O verbo 'ter' remete simultânea e simbolicamente para a posse (sinónimo de manter) e, de forma irónica e crítica, para o abandono (sinónimo de má manutenção política por parte da metrópole imperial e do governo local, o Senado). São assim apresentados cumulativamente: o paradoxal covil de freiras virtuosas, o débil governo sem rumo político, bem como o fraco poder religioso que se faz simbolizar por uma sé catedral decadente, quando deveria exibir alegorias do seu poder com opulência e grandiosidade num território em que maioria das mulheres é vil. Se Bocage critica o Senado também afirma que o território se encontra no estado miserável de que ele é testemunha devido ao abandono por Lisboa, pelo que urge ajudar a manter Macau de uma forma digna, como aliás o discurso político advogava em Portugal, nem que para tal se tivesse que retirar autonomia à edilidade do território, medida a que os moradores resistem, por exemplo, logo entre 1741-1742, 1749-1752, passando a ser alvo da desconfiança de alguns políticos na metrópole. No en-

Poesias eróticas burlescas e satíricas. (2004), e contempla muitos poemas ausentes das (anteriores) edições de Inocêncio Francisco da Silva, Teófilo Braga e Hernâni Cidade. 
tanto, há diversas fontes em que religiosos e administradores elogiam os moradores de Macau. O bispo de Macau entre 1772 e 1789, D. Alexandre da Silva Pedrosa Guimarães, enaltece os moradores (1775), ${ }^{22}$ e o seu sucessor D. Marcelino José da Silva conclui, em 1791, já na cidade, que os seus moradores eram "mais dóceis" e "susceptiveis de rezão" do que se afirmava em Lisboa. ${ }^{23}$ Em 1776 o capitão-tenente Nicolau Fonseca descreve esses moradores como fieis ao reino. ${ }^{24}$ Ao contrario desses residentes, Bocage prefere enfatizar estrategicamente a imagem negativa dos habitantes de Macau, hiperbolizando-a. Sobre os juízos extremados acerca da acção dos moradores, António Vale (1997, p. xix) conclui que a conjuntura política portuguesa de então e o espaço reduzido de manobra desses mesmos agentes coloniais na China facilitou a primazia do discurso negativo. Independentemente das críticas e das medidas repressivas, os interesses locais muitas vezes falaram mais alto do que as leis de Lisboa ou Goa, sendo estas frequentemente ignoradas quando chocavam com os lucros da edilidade local. ${ }^{25}$

A caracterização de Macau como um curral pobre e decadente é elaborada através dos exercícios da enumeração e da carnavalização de elementos da sociedade macaense, onde também não parece haver educação, espiritualidade-religiosidade, nem justiça, mas apenas o poder altaneiro e déspota do Senado, órgão administrativo criado em 1583 e que sempre fora a voz dos interesses da edilidade local, ou seja, dos comerciantes macaenses. Desde cedo na história de Macau, o Senado é acusado de não cumprir as ordens régias em prol de interesses e de

22 AHU, caixa 9, doc. 8.

23 AHU, caixa 19, doc. 13.

24 AHU, caixa 10, doc. 2.

25 Arquivos de Macau, (1971, p. 222-223). 
negócios familiares e locais, pois, como é sabido, os comerciantes locais dominavam o Senado, dependendo o capitão-geral ou governador - o representante do poder régio e chefe militar - economicamente do Senado. O sujeito poético atenta assim apenas nas dimensões negativas de Macau, hiperbolizando-as sobretudo aos níveis arquitectónico e social. A administração do Senado - órgão que tem poder absoluto e parece não respeitar ninguém, nem mesmo os representantes régios (governador e ouvidor) - é criticada; daí que o texto adquira circularidade temática, pois abre com a questão do falta de governo e no final revela que esse desgoverno se deve ao poder (mau e) desmesurado do Senado, instituição que não se deixa disciplinar, nem mesmo pelo juiz provedor.

A textualização poética do mundo às avessas da cidade histórica e semi-colonial de Macau exige assim uma análise do soneto à luz do conceito bakhtineano de 'carnaval'. ${ }^{26}$ Como é sabido, podemos atribuir dois sentidos ao termo 'Carnaval': a) as festividades ritualizadas no mês de Fevereiro que reavivam a cultura popular quer da feira medieval, quer das festas que antecedem a Quaresma, e b) o carnaval enquanto aplicação dessa mesma consciência na literatura (paródia) de forma a usar esse espírito carnavalesco para denunciar e criticar excessos ao

26 Para análises da teoria do Carnaval de Bakhtin, vejam-se: Terry Castle (1987; 1984, p. 912) ("lirical theory"); Michael Gardiner (1992, p. 180) ("fulsome and naive"). Sobre críticas à visão essencialista da transgressão carnavalesca por parte de Bakhtin, vejam-se: Emmanuel LeRoy Ladurie (1979, p. 229); Terry Eagleton (1981, p. 148); Michael Bristol (1985); Linda Hutcheon (1985, p. 71-75); Robert Young (1985-1986, p. 71-92); Michael Andre Bernstein (1996, p. 9-121); Richard M. Berrong (1986); Leonard Tennenhouse (1986, p. 79); Peter Stallybrass e Allon White (1986); Gary Saul Morson e Caryl Emerson (1989, p. 433-472); Marvin K. Booker (1991); Paul Strohm (1992, p. 33-56); Konrad Eisenbichler, "Introduction" (1999); Caryl Emerson (2000); Rocco Coronato (2003); Meghan Christine Vicks (2007, p. 1-8), Benjamin Rollins (2012). 
modo, por exemplo, de Gil Vicente, processo a que chamamos carnavalização da literatura: "the transposition of carnival into the language of literature" (1984a, p. 122). O carnavalesco interessa-nos como forma de pensamento e como universo representado na literatura, ${ }^{27}$ sendo simultaneamente um modo de representação, um termo-conceito operacional, um fenómeno textual e um tropo para desconstruir e subverter parodisticamente que sobrevive principalmente como conceito no âmbito da Teoria Literária, e não tanto da História Social. ${ }^{28}$ De acordo com Lindley:

$[\ldots]$ it does so because it describes an element, a process of demystification, manifestly present in a great range of Western literature, whatever the social sources or political consequences, if any, of that element may have been outside the texts. Bakhtin is not writing [...] about social behaviour but about the ways in which social practice ("carnival") is refracted and remained in literary texts (“carnivalesque”). (1996, p. 22)

O carnaval(esco) de Bakhtin interessa-nos quer enquanto um modo literário de (compreender e) representar o mundo, quer enquanto ferramenta analítica ${ }^{29}$ para estudar o mundo às

27 David K. Danow (1995, p. 4-22), vejam-se também: Aron Gurevitch (1988, p. 176210); Ken Hirschkop, (1989, p. 3, 34); Arthur Lindley (1996, p. 17-27); Charles Platter (2001, p. 55).

28 Arthur Lindley (1996, p. 22, 70); Katherina Clark e Michael Holquist (1984, p. 304312); Peter Stallybrass e Allon White (1986, p. 6-8); Nancy Glazener (1989, p. 113); R. Stam (1989, p. 96); Sue Vice, Introducing Bakhtin (1997, p. 149-156); Dan Krier e William J. Swart (2012, p. 135-168).

29 Stallybrass e White (1986, p. 7-8) definem o carnavalesco como uma categoria epistemológica e uma potente inversão crítica de todas as hierarquias oficiais, um mundo onde tudo se encontra degradado e sem identidade. Emerson (2000, p. 203-204) sumari- 
avessas no soneto de Bocage. Como o poema revela, o carnavalesco é também uma visão parodística, subversiva e até indecorosa, uma estratégia literária através da qual a vida religiosa, política e social de Macau é reduzida ao universo de um indecoroso e vazio curral, sem lei nem qualquer traço de espiritualidade, civilidade ou cultura. Trata-se de uma visão (HirschKop, 1989, p. 35) que, no soneto, faz parte de um projecto político próximo do espírito do Carnaval que celebra "temporary liberation from the prevailing truth and from the established order" e marca "the suspension of all hierarchical rank, privileges, norms and prohibitions" (BAKHTIN, 1984b, p. 10), pelo que não há um poder legítimo vigente em Macau, nem disciplina, a não ser a dos interesses privados, tornando-se a urbe "a space of and for fantasy" (Chedgzoy, 2000, p. 56, 62). O Carnaval é a festa também da renovação, sendo usado por Bocage como ferramenta literária e ideológica (política) para satirizar e criticar os poderes e até a população de uma Macau deserta e animalizada, que se deve renovar. Se o Carnaval pode ser interpretado como uma metáfora crítica (STEWART, 1984, p. 143-145), a desordem institucional, o imaginário corporal grotesco, a cultura não oficial e a inversão ritual são elementos do "carnival sense of the world" estudado por Bakhtin (1984a, p. 107-108, 123, 158) e outros autores e que existe no poema bocageano, sobretudo ao nível temático.

Como é sabido, em Macau o governador dependia financeiramente do Senado pelo que nunca poderia gozar de autonomia plena, dedicando-se apenas à esfera militar. ${ }^{30}$ Não seria,

\footnotetext{
za as três principais linhas do 'carnival rethinking' no pensamento contemporâneo: como um ritual sacralizado, como uma alegoria demonizada ou estalinizada, com as formas mais neutrais de o encarar como um artifício analítico nos estudo literários: "we cultivate laughter as a route to knowledge. This was Bakhtin's point".
}

30 Veja-se António Martins do Vale (1997, p. 2-15.) 
portanto, de estranhar que quer o Conselho Ultramarino, em 1735 e 1750, quer o secretário de estado da Marinha e Ultramar, Martinho de Melo e Castro, em 1783, achassem que era "necessário dar maior autoridade aos Governadores de Macau, e muni-los de alguma força militar, que os faça mais respeitados". ${ }^{31}$ O político pretende que o governador passe a presidir no Senado e a intervir na administração da fazenda real para assim se fortalecer o mitigado poder do representante régio. No entanto, a corrupção era também comum entre os governadores, ${ }^{32}$ que se associavam ao Senado para obter lucros pessoais, como o próprio Silva Ferreira recorda a Martinho de Melo e Castro em 1784 relativamente a Salema de Saldanha. ${ }^{33}$ Se o governador era, em nome da Coroa, a primeira autoridade em Macau, não tinha qualquer poder real e eficaz, sendo a sua relação com o Senado marcada pela permanente tensão que advém da medição de forças. ${ }^{34}$

$\mathrm{O}$ último terceto do poema encerra a chave interpretativa do poema, ao revelar a crítica ao (des)governo do Senado, atribuindo-lhe as culpas pelo estado degradado da sociedade local. A leitura bakhtineana do soneto permite-nos concluir que o sujeito poético pede a Lisboa que ponha termo ao caos do Carnaval imposto pelo Senado e traga a ordem simbólica da Quaresma a Macau, pelo que seria o governo apolíneo e equilibrado do governador que travaria o séquito e a desordem dionisíaca na vida pública e na sociedade de Macau. Aliás, a documentação redigida pelo ouvidor (PIRES, 1988, p. 72) corrobora a imagem

31 Parágrafo 19 das "Instruções a D. Frederico Guilherme de Sousa" (Múrias, 1988, p. 7) e AHU, caixa 6, doc. 47.

32 AHU, caixas 17, doc. 26, e 19, doc. 30, parágrafo 18 da "Instrução", p. 18.

33 AHU, caixa 16, doc. 3

34 Cf. António Martins do Vale (1997, p. 15, 35-59). 
do território administrativa e socialmente degradado veiculada pelo poema escrito pelo seu amigo protegido Bocage, ou seja, o soneto ecoa apenas a opinião do juiz relativamente aos aspectos que ele critica em Macau. Os já referidos confrontos entre a população e o juiz Ferreira surgem do controle por ele exercido na administração do território, até então da responsabilidade do Senado e da edilidade local, levando a chegada do juiz a novas restrições na administração pública. O próprio Lázaro Ferreira reconhece em 1790 que todas as "reais providências têm sido sumamente odiosas aos moradores de Macau, quase todos clamam pela novidade delas, refugiando-se na calúnia, e na falsidade com que procuram iludi-las [...], não querem Ouvidor que lhes lembre as dívidas, que lhes dificulte empréstimos novos, ou os obrigue a pagarem os antigos". ${ }^{35}$ Não admira, portanto, que Bocage comece por cantar a falta de governo na cidade, servindo o propósito de elogiar indirectamente a acção de controle da administração por parte do juiz seu amigo, que pretende acabar com o desgoverno referido no poema. Com efeito, a população local rejeita o ouvidor sobretudo porque reage mal às reformas de 1873 (implementadas a partir de 1874), que passariam a controlar as contas e a administração da cidade, em detrimento dos interesses (financeiros) da elite local, que perdia assim parte do seu poder e da autonomia com que até então administrava a cidade. Após um período de pouca comunicação entre Portugal e Macau (1754-1770) devido ao esforço de reconstrução de Lisboa após o Terramoto, à expulsão dos Jesuítas, ao processo dos Távora e a prioridade colonial conferida ao Brasil, em finais da década de 1760 e no início da década seguinte, o Reino, tal como

35 Carta de Lázaro da Silva Ferreira a Martinho de Melo e Castro (20-01-1789): AHU, caixa 18, doc. 21 e António Martins do Vale (1997, p. 17-19). 
Bocage faria, reconhece o abandono de Macau e decide analisar a situação do enclave (organização político-administrativa, administração da fazenda real, sociedade e economia, história de Macau) para melhor o controlar e reformar. Martinho de Melo e Castro, Secretário de Estado da Marinha e Ultramar, pede a Goa e a Macau que lhe enviem informações detalhadas sobre o território luso-chinês para preparar essa reforma administrativa. Surgem assim as "Instruções de 1783" (a D. Frederico Guilherme de Sousa) que visam estreitar a relação entre Macau e Lisboa e reduzir a autonomia local. O Senado recusa as novas reformas com a justificação de que não servem à cidade (VALE, 1997, p. 19, 59-69). Como já afirmámos, a cidade calunia e critica o desembargador quando ele regressa a Macau em 1787 para assumir o novo cargo, e mais de dez anos depois da sua chegada ainda o caracterizam como um "espírito de vaidade" e referem as ameaças de prisão com que ele exercera o seu poder. ${ }^{36} \mathrm{O}$ soneto de Bocage reflecte directa e indirectamente o contexto histórico que acabámos de apresentar, ficando claro para o leitor informado que o poeta elogia indirectamente toda a acção e o controlo do seu amigo ouvidor e critica de forma hiperbólica o estado de degradação da cidade devido aos interesses dos senadores. É portanto óbvio que o conhecimento do contexto histórico em que Bocage residiu na urbe e redigiu o poema, bem como das instituições e práticas referidas no soneto nos permitem uma interpretação mais profunda da que surgiria se tivéssemos atentado apenas (ou sobretudo) na vertente estética/literária desse texto.

O incipit aliterativo do soneto remete para a administração portuguesa do enclave, tema que indica logo o cariz sobretudo políti-

36 Representação do Senado à rainha (20-03-1798), AHU, caixa 21, doc. 5 e António Martins do Vale (1997, p. 19). 
co do texto. Essa atitude por parte de Bocage não é de admirar se atentarmos no apoio dado pelo governador e pela elite local ao poeta após a sua chegada e quando do seu regresso a Portugal. No entanto, também o poder religioso não tem "mando". O segundo verso caracteriza as freiras através de um único termo negativo ("covil"), sendo também enumerados os três conventos de ordens masculinas, cinco mil nhons e chineses cristãos que prevaricam. O termo do crioulo macaense 'nhon' (ou nhum; feminino: nonha) utilizado no último verso da primeira quadra significa 'senhor' e designa os homens mestiços ou crioulos do enclave. ${ }^{37} \mathrm{O}$ importante grupo étnico ou comunidade macaense marca assim presença no poema, tal como noutros textos de residentes/viajantes portugueses, nomeadamente a narrativa de viagem de Adolfo Loureiro (1896, p. 23). É ainda curioso o uso da expressão "china cristão" - que então designava ambiguamente quer os naturais de Macau (macaenses), quer os recentemente convertidos (chamados cristãos novos) — que são assim associados pelo sujeito poético ocidental aos crioulos macaenses, enquanto os reinóis são referidos num outro verso do poema. Há, portanto, uma divisão étnica, social e religiosa da população, não sendo mencionados nem os escravos, nem os estrangeiros que aí já residiam (PugA, 2009b). Aliás, a fonte "Notícias e Reflexões sobre a Cidade de Macau", redigida nessa mesma altura, descreve a comunidade portuguesa (diríamos hoje, lusófona) como constituída por "habitantes da dita cidade que se compõem de Portugueses nascidos em Portugal [reinóis], de Portugueses nascidos na Índia, a que se chamam mestiços, de Chinas Cristãos que não têm sangue Português, a que chamam naturais, de escravos cafres e

37 Veja-se Graciete Nogueira Batalha (1977, p. 229-230). A autora afirma que a forma tem origem provável nos dialectos afro-portugueses (por exemplo, de Cabo Verde). 
Timores". ${ }^{38}$ Os chineses cristãos eram considerados e incluídos pelos portugueses no grupo dos vassalos do rei de Portugal, embora ficassem sob a alçada do Mandarinato, que administrava os 30000 chineses que em 1788 residiam em Macau. ${ }^{39}$ As freiras a que o sujeito poético se refere eram as clarissas (do Convento de Santa Clara), afirmando o padre Manuel Teixeira que "a palavra 'covil' referia-se à clausura rigorosa dessas freiras" (TeIXeIRA, 1997, p. 284). As clarissas eram consideradas "honradas" como revela o relatório do bispo de Macau D. Alexandre Guimarães (1775), que, por sua vez, critica os franciscanos e agostinhos por não viverem como religiosos mas em permanente festa, ${ }^{40}$ ou seja, preferindo o 'Carnaval' à 'Quaresma'. As clarissas encontravam-se em Macau, vindas de Manila, desde 1633 e eram sobretudo uma comunidade espiritual, que vivia em reclusão. O Convento de Santa Clara era a única instituição religiosa feminina, e, em Julho de 1831, a jovem unitária norte-americana Harriet Low, ao visitar a capela de Santa Clara, assiste aos votos de ingresso de uma noviça no Convento, cerimónia que tenta descodificar ao descrever o ritual de forma negativa (LOW, 2002, p. 242243). Já os três conventos referidos pelo sujeito poético são o de São Francisco - fundado no final de 1579 por franciscanos idos de Manila, e cuja igreja se encontrava em ruínas em 1780 - o Convento de São Domingos — que tem as suas origens por volta

38 AHU, caixa 6, doc. 47, fol. 9. Em 1774 existiam em Macau: 109 portugueses (reinóis), 200 filhos de portugueses, 669 naturais e nhons, 12 chineses cristãos, 23 clérigos seculares, 5 minoristas e tonsurados, 18 religiosos, 30 religiosas, 527 mulheres casadas, 321 viúvas, 1354 solteiras, 627 crianças, 6 indianos, 1060 escravos, 9 libertos e 2 estrangeiros, num total de 4973 moradores (AHU, caixa 8, doc. 6).

39 Carta do Senado à rainha D. Maria I (12-01-1788), in Arquivos de Macau, (1972, p. 52-54). Em 1791 a população de Macau contava com 5233 não chineses, 22000 chineses, num total de 27233 habitantes (AHU, caixa 19, docs. 20-21).

40 AHU, caixa 9 doc. 8. 
de 1586, com a ida de religiosos das Filipinas para Macau, tendo a igreja actual sido erguida/remodelada em 1721 —, e o Convento de Santo Agostinho, fundado no século XVI por padres espanhóis das Filipinas.

A primeira quadra inicia-se a construção da imagem negativa do enclave, encontrando-se a dimensão sínica (a maioria da população) praticamente ausente do texto, que se ocupa sobretudo da minoria lusa, com quem o poeta teria privado durante a sua curta estada em Macau. O sentimento anti-clerical e a imagem negativa e carnavalizada do espaço exótico são transportados para a segunda quadra, que nos apresenta um edifício de prestígio, a Sé Catedral, "com catorze prebendados, sem ceitil”, rodeada por miséria social e humana, prostituição em larga escala e uma centena de portugueses, número corroborado pelas fontes históricas que listam 100 portugueses idos de Portugal (reinóis) em Macau nos anos de 1773, 1774. ${ }^{41}$ Como revelam as fontes históricas, a prostituição era efectivamente um fenómeno generalizado no período em que Bocage visita o território. $\mathrm{O}$ peso da moral católica recai sobre as mulheres da cidade que vendem serviços sexuais e castiga-as ao recolhê-las no asilo de Maria Madalena e ao enviá-las para Timor. Mas os lucros do negócio da prostituição eram tão elevados que o bispo encontra oposição e um conflito com o desembargador Lázaro da Silva Ferreira, resignando o seu cargo quando o governo lhe ordena que feche o recolhimento. As prostitutas são 'corrigidas' no referido asilo e aprendem a coser roupa, e as reclusas incorrigíveis são enviadas para a prisão timorense, encontrando-se subjacente a essa medi-

41 AHU, caixa 6, doc. 47; caixa 8, doc. 6; caixa 19, doc. 17. Em 1791 a designação "português" (reinol) deixa de aparecer na documentação, sendo, como veremos adiante, a diferenciação da população a partir de então feita com base no sexo e estado civil (AHU, caixa 19, doc. 17, veja-se também caixa 12, doc. 9). 
da a representação do papel, das funções sociais da mulher europeia 'de boa conduta', que se deveria dedicar à vida doméstica. Por esta altura, o Senado informa D. João, príncipe regente de Portugal, que os estrangeiros, ao estabelecerem-se de forma permanente em Macau, "acarretariam" as suas diversas religiões, adiantando que a riqueza destes "tem conduzido lastimozamente à prostituição muitas Donzellas pobres [e] o seu luxo, costumes, vícios também $[\ldots]$ conduz $[\ldots]$ a muitas despezas", ${ }^{42}$ ideia repetida pelo bispo Marcelino José da Silva, em 1793, ao afirmar que alguns moradores vendem os serviços sexuais das suas filhas, mulheres e irmãs aos europeus, revoltando-se quando estes não os aceitam (TeIXeIrA, 1984, p. 679). Surgem assim na segunda metade do século XVIII medidas moralistas por parte da Igreja para erradicar a prostituição (VALE, 1997, p. 141-144, 168-169) que Bocage refere. O referido edifico da Sé Catedral, dedicado à Natividade de Nossa Senhora, encontrava-se numa das zonas mais elevadas da cidadela cristã, datava de 1622 e recebera poucos melhoramentos. Com é sabido, a 'prebenda' é o direito de um eclesiástico a receber um subsídio, mas, na altura, o Senado alegava não ter dinheiro para pagar prebendas. Os "catorze prebendados" referidos no segundo verso da segunda quadra eram os então três cónegos (José Antunes, José Simões de Carvalho e Gregório João Nepomuceno) e os demais padres que faziam serviço na Sé (por falta de cónegos) como capelões e cantores, bem como os prelados, que, como não recebiam o ceitil, requereram, por volta de 1785, à rainha D. Maria I que lhes fossem dadas as côngruas pelo rendimento da Câmara de Macau (VAle, 1997, p. 137-150). A ausência do pagamento de côngruas era decerto um dos motivos para a referida falta de zelo do clero secular. O

42 AHU, caixa 21, doc. 37, fls. 3-4 (31-12-1800). 
"Mapa da População de Macau" anexo à carta do governador de Macau (4-12-1791) lista os residentes das três freguesias de Macau, dos conventos e do Seminário de São José, e, ao contrário do que acontecera em 1773, já não os divide em "portugueses", "filhos dos portugueses e mestiços", "Chineses cristão ou naturais" e "escravos", ${ }^{43}$ mas em: mulheres e homens casados, solteiros e viúvos, crianças até aos doze anos, servos e escravos, chineses cristãos e enfermos. ${ }^{44}$

As três freguesias referidas são a da Sé, a de São Lourenço e a de Santo António, ${ }^{45}$ cujas empobrecidas igrejas exibiam apenas madeiras podres ou atacadas pela formiga branca ${ }^{46}$ ("ornatos é pau”). O vigário-geral (governador do bispado) entre 1780 e 1791 foi o padre António Jorge Nogueira, e se, de acordo com o soneto, o rei não detinha poder na cidade, as fontes revelam que também não havia bispo desde 1778, quando D. Alexandre Guimarães fora forçado pelo rei a regressar a Portugal. Já o vigário-geral era o governador do bispado, não havendo também promotor de justiça do Juízo Eclesiástico entre 1789 e 1790 (TeixeIra, 1997, p. 287). O sucessor de D. Alexandre Guimarães, o bispo Marcelino José da Silva, foi nomeado em 1789, mas só chegaria a Macau em Setembro de 1791, e, já no enclave, ecoa o conteúdo do poema de Bocage ao queixar-se, em carta a Martinho de Melo e Castro (1791), que a população vive como se não fosse cristã, criticando o luxo, o ócio e a prostituição. ${ }^{47} \mathrm{O}$ território carnavalizado é assim metaforizado e descrito como um peque-

\footnotetext{
43 "Relação das Casas Ricas de Macau": AHU, caixa 6, doc. 47.

44 AHU, caixa 19, doc. 17.

45 Em 1774, a freguesia da Sé, a mais populosa, tinha 2114 residentes, a de São Lourenço 1793 residentes e a de Santo António 1017 residentes (AHU, caixa 8, doc.6).

46 Frei José de Jesus Maria (1988, vol. 1, p. 150); AHU, caixa 7, doc. 41.

47 AHU, caixa 19, docs. 15 e 20.
} 
no "curral" (a cidadela cristã envolvida e defendida por muralhas) delimitado de um lado pelo rio das Pérolas, do outro pelas Portas do Cerco, outra cerca metafórica e a que possivelmente o sujeito poético também aludiria jocosamente através do trocadilho 'Cerco-cerca do curral', animalizando, portanto, a sociedade local e hiperbolizando algumas das suas características negativas. O curral poderá remeter também quer para o isolamento geográfico e politico de Macau, território chinês sob co-administração portuguesa, quer para a atitude passiva dos moradores face às exigências do Mandarinato, até porque dependiam dos chineses para obter víveres ${ }^{48}$ mão de obra e desenvolver o comércio. Essa obediência e as relações cordiais que Bocage poderá eventualmente ter criticado - ao ecoar discursos políticos que se ouviam em Lisboa - foram, no entanto, um dos fortes motivos da sobrevivência de Macau até 1999, até porque o território nunca foi uma colónia portuguesa, e os portugueses nunca aí tiveram plenos poderes, nem total soberania. Aliás o desrespeito pelas imposições chinesas teria levado ao abandono forçado do enclave pelos portugueses. $^{49}$

O primeiro terceto ocupa-se da dimensão militar e refere seis fortes, que, como sabemos, são: São Paulo do Monte (16121626), Santiago (1616-1629), Nossa Senhora da Penha de França (melhorado em 1622), Nossa Senhora do Bom Parto (c.1622), São Francisco (1622-1626) e Nossa Senhora da Guia (reconstruído em 1637-1638), não sendo obviamente contemplados os fortins de S. Jerónimo, de São Pedro e de São João. A dimensão militar enfraquecida é ineficaz, e são tantos os soldados como os

48 Em 1784, o próprio ouvidor Silva Ferreira refere o bloqueio de alimentos e o embargo ao comércio feitos pelos chineses aos portugueses até que estes últimos respeitem as suas exigências (AHU, caixa 16, doc. 11).

49 AHU, caixa 5, doc. 31. 
residentes portugueses referidos na estrofe anterior. Os militares contam com poucas armas e um só "tambor", marca da imagem acústica (silenciosa), que reforça a debilidade militar da cidade, que se encontra (e sente) abandonada por Lisboa. O número de soldados que o poema afirma residir no enclave é corroborado pelas fontes históricas, pois em Abril de 1783 Martinho de Melo e Castro informa que residiam em Macau 79 soldados, oito sargentos e dois tambores, que as tropas são comandadas por um sargento-mor e que cada fortaleza tinha um capitão. No Monte existia um capitão e cada sargento-mor tinha às suas ordens dois alferes, logo a guarnição militar da urbe rondava os 96 militares, ${ }^{50}$ um número próximo do avançado pelo soneto de que nos ocupamos, os cem militares que, em 1775, o bispo D. Alexandre da Silva Pedrosa Guimarães considerava ser o número ideal para defender a urbe. ${ }^{51}$

O segundo terceto revela o fraco nível da educação local ao criticar o 'Colégio' como "mau”, instituição que poderia ser: a) o abandonado Colégio de Madre de Deus, fundado pelos Jesuítas em 1594, b) o Colégio de São José, fundado também pelos Jesuítas em 1732 e que a partir de 1784 foi entregue aos Lazaristas, ou c) a escola elementar onde ensinava o clérigo António José Sales, a Escola de Ler, Escrever e Contar. O Colégio de Madre de Deus encontrava-se degradado, tendo sido já demolidas algumas oficinas que estavam em ruínas. Recorde-se os Jesuítas foram expulsos de Portugal em 1759 e do império em 1762, tendo a qualidade da educação decaído por falta de substituição das instituições de

50 Ver parágrafo 10 das "Instruções a D. Frederico Guilherme de Sousa, governador e capitão-general da Índia” (Múrias, 1988, p. 3), e AHU, caixa 6, doc. 47 e António Martins do Vale (1997, p. 5).

51 Cartas de D. Alexandre da Silva Pedrosa Guimarães para Martinho de Melo e Castro, 08-01-1775 e 01-12-1777: AHU, caixa 8, docs. 6, 8 e caixa 11, doc. 25. 
ensino da Sociedade de Jesus. Aliás, o amigo de Bocage indirectamente visado no poema, o desembargador e governador interino Silva Ferreira, informava Goa no final de 1784, que

[...] depois da extinção dos Jesuítas cessam aqui as escolas. Não houve mais uma cadeira de latinidade, nenhuma de moral ou teologia. Quem quis aprender foi Manila, e alguns para Goa e outros a quem os meios faltavam ficaram aqui, ouvindo lições de algum clérigo antigo [...]. O professor régio [Santos Baptista e Lima] com ordenado de 500 táeis ainda não formou um só estudante bom. As religiosas não dão aulas, nem estes conventos têm mestres. (TeIXeIRA, 1997, p. 287)

A ausência de um sistema educativo eficaz enfatiza a ignorância e a má formação da população local que facilitariam a corrupção e a defesa sobretudo dos interesses próprios dos moradores do enclave. $\mathrm{O}$ terceto final contempla ainda a administração local e critica o abandono de Macau por parte de Lisboa. Enquanto o todo-poderoso Senado tem mais poder que o governador, a Coroa abandonou o enclave, que vive na miséria e à mercê dos interesses pessoais dos senadores. O soneto assume-se como uma sintética e irónica enumeração que termina com uma crítica ao abandono de Macau e que exige um leitor informado e competente relativamente à história de Macau, pois muita da informação é sugerida nas entrelinhas. Ao longo de 14 versos, Bocage carnavaliza o enclave do seu tempo. Na primeira quadra critica os poderes administrativo e religioso, bem como a população transgressora, enquanto estabelece, na segunda quadra, um paralelismo simbólico ao equiparar a miséria da paisagem humanizada ou arquitectónica à da paisagem humana, ocupan- 
do-se dos edifícios e da sociedade decadentes. O primeiro terceto detém-se na dimensão militar enfraquecida, nas freguesias pobres e na ausência de um sistema de justiça eficaz, e, por fim, o segundo terceto refere o baixo nível da educação e da administração locais, enquanto critica o poder central colonial.

Uma das questões levantadas pela análise do soneto de Bocage é a capacidade de a poesia representar o mundo extra-literário. A partir do poema, podemos atestar a possibilidade da poesia para representar ou sugerir, mesmo que de forma subjectiva e até parcial (porque política), a realidade externa ao texto ao encapsular episódios, práticas, ideias e até conceitos de cariz historico-político, ou seja, os referentes extra-literários que não devem ser confundidos com os elementos reais assim poetizados. A relação entre poesia e história e a presença desta última na literatura enquanto tema e artifício narrativo supõe, desde logo, a existência de referentes extratextuais verificáveis, que sustentam parte da rede de significações do texto poético, mas que não devem ser considerados reflexos exactos da realidade. Até porque, como demonstra o soneto de Bocage, estes podem ser desfamiliarizados, ficcionalizados ou carnavalizados, por exemplo, em prol de interesses pessoais. Deveremos assim também ponderar as possibilidades e liberdades da poesia enquanto género, e da história como fenómeno capaz de ser textualmente representado. Se em 1972 Eduardo Lourenço refere, em O Labirinto da Saudade: Psicanálise do Destino Português, o longo processo literário de mitificação do Oriente (Lourenço, 1978, p. 2), o poema de Bocage de que nos ocupámos poderá ser considerado um exercício (com fins políticos e 'partidários') de crítica colonial e de desmistificação da empresa, missão e presença lusas nesse reduzido espaço cronotopicamente distante, construído e mantido nas fraldas do Império do Meio e do império português. O objectivo político 
do soneto, que aliás não tem grande valor literário, faz com que o sujeito poético omita muitas outras dimensões que enriquecem o território - a comercial, a económica, a intercultural e a chinesa -, e fá-lo estrategicamente em prol de uma enumeração descritiva deveras ideológica e parcial, como o costumam ser os universos carnavalizados.

\section{Bibliografia}

\section{Fontes manuscritas}

Arquivo Histórico Ultramarino (Lisboa)

Macau:

caixa 6 , doc. 47 ,

caixa 7 , doc. 41 ,

caixa 8 , docs. 6,8 ,

caixa 9 doc. 8 ,

caixa 11 , doc. 25 ,

caixa 17 , docs. $3,26,68$,

caixa 18, docs. 21, 34, 44,

caixa19, docs. 7, 15, 17, 20-21, 30, 34,

caixa 20, docs. 10-11,

caixa 21 , docs. 5,37 .

\section{Fontes Impressas}

Arquivos de Macau, $3^{\mathrm{a}}$ série:

vol. 16, n. 4,1971

vol. 17, n. 1, 1972.

Beckford, William. Italy: with Sketches of Spain and Portugal. v. 1. Londres: Richard Bentley, 1834. 
Burton, Richard Francis. Goa and the Blue Mountains or Six Months of Sick Leave. Londres: Richard Bentley, 1851.

"Instruções a D. Frederico Guilherme de Sousa". In: Múrias, Manuel (ed.) Instruções para o Bispo de Pequim e outros Documentos para a História de Macau. Macau: Instituto Cultural de Macau, 1988.

Loureiro, Adolfo. No Oriente: De Nápoles à China. Lisboa: Imprensa Nacional, 1896-1897. 2 v.

Low, Harriet. Lights and Shadowes of a Macao Life: The Journal of Harriet Low, Travelling Spinster. v. 1. Woodinville: The History Bank, 2002.

Maria, Frei José de Jesus. Ásia Sínica e Nipónica. v. 1. Macau: Instituto Cultural de Macau, 1988.

Múrias, Manuel (Ed.). Instruções para o Bispo de Pequim e outros Documentos para a História de Macau. Macau: Instituto Cultural de Macau, 1988.

\section{Textos Literários}

Bocage, Manuel Maria Barbosa du. Opera Omnia. ed. Hernâni Cidade. Lisboa: Livrara Bertrand, 1969. . Obra Completa, vol. 2: Cantatas, Canções, Idílios, Epistolas,

Odes e Cantos. ed. Daniel Pires. Porto: Caixotim, 2005.

\section{Estudos}

Bakhtin, Mikhail. Problems of Dostoevsky's Poetics. Minneapolis: University of Minnesota Press, 1984a. 
Rabelais and his World. Bloomington: Indiana University Press, 1984b.

Batalha, Graciete Nogueira. Glossário do Dialecto Macaense: Separata da Revista Portuguesa de Filologia, vols. xv-xvii, p. 229-230, 1971, 1974 e 1977.

Bernstein, Michael Andre. When the Carnival Turns Bitter: Preliminary Reflections upon the Abject Hero. In: Monson, Gary Saul (Ed.). Bakhtin: Essays and Dialogues on his Work. Chicago: University of Chicago Press, 1996. p. 9-121.

Berrong, Richard M. Rabelais and Bakhtin. Londres: University of Nebraska Press, 1986.

Booker, Marvin K. Techniques of Subversion in Modern Literature: Transgression, Abjection, and the Carnivalesque. Gainesville: University of Florida Press, 1991.

Bové, Paul A. Poetry against Torture: Criticism, History and the Human. Hong Kong: Hong Kong University Press, 2008.

Braga, Teófilo. História da Literatura Portuguesa, Bocage, Sua Vida e Época Literária. Porto: Livraria Chardron, 1902.

Bristol, Michael. Carnival and Theater: Plebian Culture and the Structure of Authority in Renaissance England. Nova Iorque: Methuen, 1985.

Castle, Terry. Masquerade and Civilization: The Carnivalesque in Eighteenth-Century English Culture and Fiction. Stanford: Stanford University Press, 1987.

The Carnivalization of Eighteenth-Century English Narrative. PMLA, v. 99, p. 903-916, 1984. 
Chedgzoy, Kate. "For Virgins Buildings Oft Brought Forth": Fantasies of Convent Sexuality. In: D’Monté, Rebecca; PoHL, Nicole (ed.). Female Communities, 1600-1800: Literary Visions and Cultural Realities. Houndsmills: St. Martin's Press, 2000. p. 53-75.

Clark, Katherina; Holquist, Michael. Mikhail Bakhtin. Cambridge: Harvard University Press, 1984.

Coronato, Rocco. Jonson versus Bakhtin: Carnival and the Grotesque. Nova Iorque: Rodopi, 2003.

Danow, David K. The Spirit of Carnival: Magic Realism and the Grotesque. Lexington: The University Press of Kentucky, 1995.

Domingues, Mário. Bocage, a sua Vida e a sua Época: Evocação Histórica. Lisboa: Romano Torres, 1962.

Eagleton, Terry. Walter Benjamin or Towards a Revolutionary Criticism. Londres: Verso, 1981.

EISENBICHLER, Konrad. Introduction. In: EISENBICHLER, Konrad; Hüsken, Wim (Ed.). Carnival and the Carnivalesque: The Fool, the Reformer, the Wildmen, and others in Early Modern Theatre. Amesterdão: Rodopi, 1999. p. 7-18.

Emerson, Caryl. The First Hundred Years of Mikhail Bakhtin. Princeton: Princeton University Press, 2000.

Gardiner, Michael. The Dialogics of Critique: M. M. Bakhtin and the Theory of Ideology. Londres: Routledge, 1992.

Glazener, Nancy. Dialogic Subversion: Bakhtin. The Novel and Gertrude Stein. In: Hüsken, Ken; Shepherd, David (Ed.). Bakhtin and Cultural Theory. Manchester: Manchester University Press, 1989. p. 151-176. 
Gonçalves, Adelto. Bocage, o Perfil Perdido. Lisboa: Caminho, 2003.

Gossman, Lionel. Between History and Literature. Cambridge-MA: Harvard University Press, 1990.

Gurevitch, Aron. Medieval Popular Culture: Problems of Belief and Perception. Cambridge: Cambridge University Press, 1988.

Gusmão, Manuel. Da Literatura enquanto Construção Histórica. In: Buescu, Helena; DuARTe, João Ferreira; Gusmão, Manuel (org.). Floresta Encantada: novos caminhos da Literatura Comparada. Lisboa: Dom Quixote, 2001. p. 181-224.

Hirschkop, Ken. Introduction. In: HirschKop, Ken; Shepherd, David (ed.). Bakhtin and Cultural Theory. Manchester: Manchester University Press, 1989. p. 1-31.

Hutcheon, Linda. A Theory of Parody: The Teachings of Twentieth-Century Art Forms. Urbana: University of Illinois Press, 1985.

KrIER, Dan; Swart, William J. The Dialectics of Carnival: From Bakhtin to Baudrillard. In: Braun, Jerome; LANGMAN, Lauren (Ed.). Alienation and the Carnivalization of Society. Nova Iorque: Routledge, 2012. p. 135-168.

Ladurie, Emmanuel LeRoy. Carnival in Romans. Nova Iorque: George Brazillier, 1979.

Lindley, Arthur. Hyperion and the Hobbyhorse: Studies in Carnivalesque Subversion. Londres: Associated University Presses, 1996. 
Lourenço, Eduardo. O Labirinto da Saudade: Psicanálise do Destino Português. Lisboa: D. Quixote, 1978.

Marinho, Maria de Fátima; Topa, Francisco (coord.). Literatura e História: Actas do Colóquio Internacional. 2 v. Porto: Campo das Letras, 2004.

Marinho, Maria de Fátima. Um Poço sem Fundo: Novas Reflexões sobre Literatura e História. Porto: Campo das Letras, 2005.

Monteiro, Gomes. Bocage, esse Desconhecido. Lisboa: Romano Torres, 1943.

Morson, Gary Saul; Emerson, Caryl. Mikhail Bakhtin: The Creation of a Prosaics. Stanford: Stanford University Press, 1989.

Neff, Emery. The Poetry of History: The Contribution of Literature and Literary Scholarship to the Writing of History since Voltaire. Nova Iorque: Columbia University Press, 1961.

Palmer, Roundell. The Connections of Poetry with History, A Lecture. Londres: Whittaker, 1852.

PIres, Benjamim Videira. Os Extremos Conciliam-se: Transculturação em Macau. Macau: Instituto Cultural de Macau, 1988.

Platter, Charles. Novelistic Discourse in Aristophanes. In: BARTA, Peter et al. (Ed.). Carnivalizing Difference: Bakhtin and the Other. Londres: Routledge, 2001. p. 51-78.

Pope, Ethel M. India in Portuguese Literature. Nova Déli: Asian Educational Services, 1937.

PugA, Rogério Miguel. A World of Euphemism. Representações de Macau na Obra de Austin Coates: City of Broken Promises enquanto Romance Histórico e Bildungsroman. Lisboa: Fundação para a 
Ciência e a Tecnologia-Fundação Calouste Gulbenkian, 2009a. . A Presença Inglesa e as Relações Anglo-Portuguesas em Macau (1635-1793). Centro de História de Além-Mar, Universidade Nova de Lisboa-Universidade dos Açores, Centro Cultural e Científico de Macau, Lisboa, 2009b.

Riedel, Dirce Côrtes (ed.). Narrativa, Fiç̧ão e História. Rio de Janeiro: Imago, 1998.

Rolusns, Benjamin. Carmival's Dance of Death: Festivity in the Revenge Plays of Kyd, Shakespeare, and Middleton. Tese (Doutorado em Literatura Inglesa) - Georgia State University, 2012.

Rosa, Luís. Bocage, a Vida Apaixonada de um Genial Libertino. Lisboa: Presença, 2006.

Seixo, Maria Alzira. Literatura e História: Poética da Descoincidência em Peregrinação de Barnabé das Índias, de Mário de Carvalho. In: Marinho, Maria de Fátima; TopA, Francisco (Coord.), Literatura e História: Actas do Colóquio Internacional. v. 2. Porto: Campo das Letras, 2004. p. 231-241.

Stallybrass, Peter; White, Allon. The Politics and Poetics of Transgression. Londres: Methuen, 1986.

Stam, R. Subversive Pleasures: Bakhtin, Cultural Criticism, and Film. Baltimore: Johns Hopkins University Press, 1989.

Stewart, Marilyn. Carnival and Don Quixote: The Folk Tradition of Comedy. In: Cowan, Louis (Ed.). The Terrain of Comedy. Dallas: Dallas Institute of Humanities, 1984. p. 143-162.

Stronm, Paul. Hochon's Arrow: The Social Imagination of Fourteenth-Century Texts. Princeton: Princeton University Press, 1992. 
Teixeira, Padre Manuel. Toponímia de Macau. v. 2. Macau: Instituto Gultural de Macau, 1997. . Macau no Século XVIII. Macau: Imprensa Nacional de Macau, 1984.

Tennenhouse, Leonard. Power on Display: The Politics of Shakespeare's Genres. Nova Iorque: Methuen, 1986.

Vale, António Martins do. Os Portugueses em Macau (1750-1800): Degredados, Ignorantes e Ambiciosos ou Fiéis Vassalos d'El-Rei? Macau: Instituto Português do Oriente, 1997.

Véscio, Luiz Eugénio; Brum, Pedro (Org.). Literatura e História. São Paulo: Edusc, 1999.

VIcE, Sue. Introducing Bakhtin. Manchester: Manchester University Press, 1997.

Vicks, Meghan Christine. The Postmodern Oranus: Carnival and Abjection in Victor Pelevin's Homo Zapiens. Tese (Doutorado) - Universidade do Colorado, 2007.

WANG, David Der-wei. The Monster that Is History: History, Violence, and Fictional Writing in Twentieth-Century China. Berkeley: University of California Press, 2004.

Young, Robert. Back to Bakhtin. Cultural Critique, v. 2, p. $71-$ 92, 1985-1986.

PugA, Rogério Miguel. A carnavalização hiperbólica da Macau Setecentista num soneto de Bocage (c.1789) em prol da figura do ouvidor Lázaro da Silveira Ferreira. In: Simas, Monica (Org.). Estudos sobre Macau e outros orientes. São Paulo: Paulistana, 2017. p. 224-259. 


\section{A dor que deveras sente}

\section{Carlos Morais JOSÉ}

"De la musique avant toute chose"

Haverá uma frase de Borges que nos remete para o devaneio de na poesia se encontrarem contidas a música e a pintura, pois a sucessão de palavras - para além das ideias - conteria ritmos, melodias e imagens. Deixando, por ora, de lado a vertente contemplativa e considerando unicamente a música, não será difícil atribuir o carácter encantatório do fluir poético à existência de uma musicalidade no poema, seja ela derivada da sonoridade das palavras ou do modo como se entrelaçam, para depois se sucederem as imagens e os conceitos.

1 carlosmoraisjose@gmail.com 
Existe na poesia um efeito vibratório, musical, onde reside, se não o seu principal pólo de interesse, pelo menos a fonte de parte considerável do seu fascínio. "Os estímulos visuais", refere Ester de Lemos, "não escapam tão facilmente à vigilância da razão, não são tão facilmente encarados em si mesmos como os estímulos auditivos, sobretudo os musicais" (1956, p. 30). Se a música escapa à vigilância da razão, ela será o meio excelente para arrebatar, para suster essa poesia que "eleva cada indivíduo através de uma ligação específica com o todo restante" (Novalis, 2009, p. 121).

Este carácter sintético da poesia, em grande parte ancorado nessa musicalidade, não deverá ser entendido como referido à dialéctica, que prevê um momento de negação, mas a um mero gesto de apropriação criacionista, capaz de proporcionar polaridades outras e sistemas de leitura, o que equivale a dizer reinventar universos e abrir uma miríade de possibilidades à expressão da vida.

A sintese, na dialéctica, exprime, afinal, o culminar do processo de aculturação; no criacionismo, a função da negação, fundamental na construção da identidade, só estará presente na expressão poética como condição de sinceridade do media, como se pretendesse operar uma regressão a um estado anterior onde a graça da criança (das três metamorfoses de Nietzsche/Zaratrusta) lhe permite apoderar-se do mundo num golpe. Não se tratará, contudo, de uma regressão propriamente dita mas de uma reaquisição - a saudade é do futuro.

Se, para Rousseau, a primeira linguagem era poética, tal seria no sentido em que uma palavra dessa primitiva língua encerraria muito mais sentidos que o seu significado literal (ou que este não existiria e muitos significados estariam contidos numa palavra só) e os homens de antanho falariam basicamente por metáforas, abarcando assim mais do mundo do que eles próprios poderiam compreender, sendo a Língua o repositório de um sa- 
ber que os próprios indivíduos que a falavam apenas entenderiam parcialmente.

A poesia inscreve-se numa ânsia de apropriação do mundo e dos seus sentidos ocultos, num claro sentir filosófico em que, para além da vibração musical (mas também em ela), o poema expressa uma visão, eventualmente, o esboço ou o castelo final de uma qualquer metafísica.

É com o primeiro Romantismo que poeta e poesia exacerbam essa ânsia, assumindo o conceito poético que elevará o "homem acima de si mesmo". Trata-se, no dizer de Novalis (2009), de uma poesia "transcendental", que é "mesclada de filosofia e poesia", e que prefigura a dissolução dos sistemas filosóficos, na medida em que, "se o filósofo ordena tudo, coloca tudo, então o poeta dissolveria todos os elos. As suas palavras não são signos universais - são sons - palavras mágicas, que movem belos grupos em torno de si". Novalis remataria: "Quando mais poético, mais verdadeiro".

Parece então que, com o Iluminismo, o poeta visa a ultrapassar o mero papel mediador do xamã para aspirar a ser ele mesmo - através dessa transcendentalidade que lhe proporciona o pensamento filosófico e mesmo a ciência - uma fonte de permanente problematização, expressão radical da vida mas também das volutas do espírito, sem abdicar também do modo - mágico - como eventualmente recuperará alguns restos dessa linguagem primordial, onde se rebatiam os mistérios do mundo e das coisas.

\section{Pessanha e as "nobres especulações do espírito"}

Sem deter o exclusivo ou sequer a preponderância, poesia e filosofia particularmente se entrelaçam no espaço da Língua Portuguesa, por razões que talvez passem pelo defeito da segun- 
da e o excesso da primeira. Após o milagre grego, raramente o Sul produziu um assertivo pensamento lógico, mas as preocupações metafísicas, lidas através dos penetrantes filtros da experiência do mundo e de particulares sensibilidades, cedo se imiscuíram em temáticas versejadas. Já em Camões, para não irmos mais atrás, ao vate, ao cantor épico, se sobrepunha o homem dilacerado pela dúvida, onde o recurso à mitologia soa - além da epocalidade renascentista - ao desespero de constatar uma diversidade percorrida, revivida, recebida e, portanto, a intuição de um mundo desencantado.

Na segunda metade do século XIX, a presença cimeira de Antero de Quental - o que “ensinou a pensar em ritmo; descobriu-nos a verdade de que o ser imbecil não é indispensável a um poeta" (Fernando Pessoa) -, com certeza deu um tom definitivamente filosófico à expressão da poesia lusófona e talvez poético à filosofia pensada em português. As crises, civilizacional na Europa e muito específica em Portugal, na sequência do Ultimatum britânico, eram demasiado profundas e dolorosas para que os poetas se limitassem aos devaneios dos salões, às rimas de ocasião, enfim às actividades dos que Pessanha define como "essa legião de poeta mínimos, cuja pobre musa toda a sua fecundidade esgota na concepção de cem páginas de lirismo".

Como explica Gustavo Rubim, Camilo Pessanha critica a poesia como "uma expressão directa dos sentimentos, das sensações ou da experiência vivida do poeta e opõe-lhe uma concepção mais abstracta que inscreve o discurso poético no campo das "especulações do espírito"'. Ora para sustentar a filosofia no discurso poético, para lhe garantir o carácter especulativo, implica, como diz o autor de Experiência da Alucinação, "uma certa dimensão impessoal" (Rubim, 1993, p. 142). Ou seja, o 
que Fernando Pessoa já exprimia, quando escreveu este revelador apontamento:

A cada um de só três poetas, no Portugal dos séculos XIX a XX, se pode aplicar o nome de "Mestre". São eles Antero de Quental, Cesário Verde e Camilo Pessanha. [...] O terceiro ensinou a sentir veladamente*; descobriu-nos a verdade de que para ser poeta não é mister trazer o coração nas mãos, senão que basta trazer nelas os simples sonhos dele. Estas palavras que não são nada bastam para apresentar a obra do enorme poeta Camilo Pessanha.

O mais, que é tudo, é Camilo Pessanha.

Este "trazer nas mãos os sonhos do coração" implicará um duplo distanciamento: uma consciência primeira que, se bem que sob o filtro da sensibilidade, exige a exterioridade; e uma exterioridade que permite a reflexão distanciada. $\mathrm{O}$ poeta adquire esse distanciamento em relação a si mesmo (ao lirismo óbvio) e à possibilidade de contemplar (teorizar) o que detém agora nas mãos, operando uma espécie de processo alquímico de destilação, decantação e, finalmente, sedimentação - de sensações, sentimentos e ideias - nas palavras finais do poema. Isso é de tal modo presente em Pessanha que, mesmo quando produzia "os seus poemas por uma premente necessidade espiritual", fazia-o "numa atitude eminentemente intelectual [...] vivendo e revivendo o sentir dos momentos de concepção poética" (Dias Miguel, 1956, p. 185).

É então a poesia o canto desses sonhos do coração? O que são eles? Parece-nos que Pessoa se refere, quase falando numa linguagem gémea da de Pessanha, a um processo poético. 
Curiosamente (e tal não deverá passar de uma coincidência), no pensamento tradicional chinês, seja ele confucionista ou daoísta, o coração (xin) é a entidade onde residem as emoções, os desejos, os sentimentos, o pensamento e a moral, ou seja, ali se entrelaça toda a fenomenologia da existência interna dos seres humanos. Se entendermos coração nesse sentido, teremos então o indivíduo e todos as seus rizomas culturais nas mãos.

Mas Pessanha, por outro lado, entregava-se "ao trabalho do aperfeiçoamento da expressão, preocupado até à angústia com o sortilégio e a magia verbal, condensando e polindo de tal modo, que muitas vezes obscurecia quase totalmente o sentido biográfico e directo que tinham essas poesias", nas palavras de António Dias Miguel (1956). Assim se revelam a existência de uma matriz filosófica e uma exigência de distanciamento biográfico, a par com a demanda extrema da musicalidade.

Seguindo essas referências, parece inegável que a reflexão filosófica ocupa um lugar fundamental na poesia de Camilo Pessanha. Ainda que nem sempre explícita, a sua concepção do mundo constituiu, talvez de forma dolorosa, uma das principais episteme onde a sua poesia lançou raízes e a partir da qual se desenvolveu.

\section{A pergunta e o gelo}

Já em 1887, no poema "Soneto de Gelo", o poeta explicitava algumas das preocupações derivadas do seu dispositivo ontológico:

Eu mesmo quero a fé, e não a tenho,

- Um resto de batel - quisera um lenho,

Para não afundir na treva imensa, 
O Deus, o mesmo Deus que te fez crente...

Nem saibas que esse Deus omnipotente

Foi quem arrebatou a minha crença.

Ou seja: a ausência da fé, uma existência num mundo sem Deus e, consequentemente, a morte como fronteira de dissolução do indivíduo. O poeta quisera uma pequena prova, ainda que só "um lenho", de "um resto de batel" (a barca, baraka - animal fantástico, montada de Abraão e Maomé, que na mitologia islâmica opera a comunicação entre dois mundos), algo onde se suster, que o não deixe "afundir na treva imensa" de um universo vazio de sentidos divinos ou de quaisquer outras satisfatórias respostas.

É precisamente essa "treva imensa", o segredo insondável, que provoca no poeta o início de uma profunda dor metafísica, quase revolta contra a divindade pelo seu silêncio/inexistência e sua consequente falta de fé. Se foi Deus "quem arrebatou a minha crença", é porque o estado de descrença é anterior ao próprio advento do raciocínio científico-filosófico ou da intromissão da cultura. É certo que a falta de fé surgirá também como decorrente do próprio ZeitGeist, da posição do poeta num dado momento civilizacional. É a religião na qual foi educado, as relações familiares, a escola frequentada, o valor atribuído ao conhecimento científico, a sociedade emergente, enfim, o conjunto global de valores e procedimentos que constituem uma Cultura num determinado momento da História, que tornavam problemática a existência de Deus. Mas Pessanha parece afirmar que sente a sua descrença, de algum modo, anterior, constitutiva e fatal, porque lhe foi arrebatada por Deus, o que não deixa de exalar uma paradoxal ironia.

A extinção da crença resultará como anteriormente resultava a sua afirmação: sem que o sujeito nela tenha uma real 
intervenção. Pessanha assume neste poema o seu ateísmo como condição (dolorosa) e não como decisão consciente. Até porque o novo universo, dessacralizado, não lhe fornece respostas. Simplesmente, efemeramente o admite, na sua fria indiferença, sem proporcionar qualquer consolo às angústias fundacionais dos humanos.

O poeta refere esse mal-estar matricial no poema "Estátua":

Cansei-me de tentar o teu segredo:

No teu olhar sem cor, - frio escalpelo,

O meu olhar quebrei, a debatê-lo,

Como a onda na crista dum rochedo.

Segredo dessa alma e meu degredo

E minha obsessão! Para bebê-lo

Fui teu lábio oscular, num pesadelo,

Por noites de pavor, cheio de medo.

E o meu ósculo ardente, alucinado,

Esfriou sobre mármore correcto

Desse entreaberto lábio gelado:

Desse lábio de mármore, discreto,

Severo como um túmulo fechado,

Sereno como um pélago quieto.

O cansaço de procurar respostas no olhar - acto que remete para a contemplação, a teoria - dá lugar à ousadia do beijo - acto amoroso, a poesia. No primeiro caso, a contemplação esbarra e quebra-se "como a onda na crista de um rochedo". No 
segundo, produz-se um esfriamento do que era "ardente, alucinado". Ou seja, nem a razão consegue penetrar o insondável; nem um extremo desejo e uma vitalidade transbordante obtêm outro resultado que não seja a sua própria dissolução. Em ambos os casos, sobrevém uma existência assombrada pelo silêncio.

Emana, de facto, deste poema uma sensação de horror perante um universo feito estátua, em cuja indiferença nem Razão nem Vida penetram. Estátua porque, se bem que gelado e silencioso, de olhar sem cor como as estátuas gregas, ainda assim, tal como a escultura clássica, o universo não deixa de exibir uma certa ordem e exalar uma profunda beleza. Tal acentua o sofrimento do poeta perante a impossibilidade de - não de o conhecer - mas de beber esse segredo. Não serão os conhecimentos científicos, racionais, que trariam satisfação a Camilo Pessanha, pois estes nem de perto pretendem responder às questões que o habitam. Mas, mesmo face às suas ousadias, de pesadelo, nada acontece a não ser o esfriamento perante a gravitas de um "túmulo fechado" ou de um "pélago quieto".

Pessanha habita um universo novo, que a ciência descreve através das teorias quânticas, do princípio da incerteza, da transformação sucessiva de matéria em energia e de energia em matéria, em que a própria matéria não é mais que uma vibração ou ondulação, obediente a ritmos misteriosos, desconhecidos mas dessacralizados.

Não será também o uno conceito de Vontade, de Schopenhauer - como tem sido repetidamente afirmado por uma ligação rápida ao dito pessimismo do alemão -, que aqui estará em jogo. Não existe uma Vontade (conceito eivado de metafísica), mas um palimpsesto de forças, de energias, de vibrações, num universo em que as formas se limitam a uma existência efémera como no poema "Imagens que passais pela retina dos meus olhos / Porque 
não vos fixais?”, em que tudo é transitório e de sentidos vagos. Os "olhos pagãos" somente vêem os "sucessivos desertos". E nem a sua presença deixará qualquer rasto: "Fica sequer, sombra de minhas mãos".

No lugar de Deus não existirá nada, sequer faz sentido o panteísmo de Espinosa. A ideia de um ser divino, antropomórfico ou disseminado, dará lugar a esse resfolgar contínuo de todas as coisas, essa dimensão pulsante que permite supor a existência de um ritmo primordial, incessante, inesgotável, sem face nem propósito, sem leis morais, mera energia e mera matéria, em permanente metamorfose, como o poeta sussurra ainda no seu leito de morte, à laia de despedida: "Tudo podridão... tudo matéria..." E podridão, o leitor do Octave Mirbeau de "O Jardim dos Suplícios", novela passada em Cantão no século XIX, que Pessanha certamente era, sabe que significa metamorfose.

Num plano mais pessoal, é a ausência de uma consciência divina que torna fútil a crença num destino, dando ao indivíduo a sensação solitária de à toa marear na vida, tornando-a também a ela fútil e levando à invocação da morte como acto estético último, no sentido borgesiano da iminência de uma revelação que não se produzirá.

Enfim, levantou ferro.

Com os lenços adeus, vai partir o navio.

Longe das pedras más do meu desterro

Ondas azuis do oceano, submergi-o.

Que eu, desde a partida,

Não sei onde vou.

Roteiro da vida

Quem é que o traçou? 
A sensação de inutilidade da vida ("Foi um dia de inúteis agonias"... "Floriram por engano as rosas bravas...") percorre a obra de Pessanha. A vivência num mundo desencantado, sublinhada pela decadência do país, estriba-se numa ontologia melancólica, onde a aura materialista acaba por ser, em confronto com a sensibilidade do poeta, fonte de uma inextirpável dor.

Camilo Pessanha será um daqueles primeiros homens a ter nascido no mundo de um Deus morto (Nietzsche), mas onde a estrutura religiosa se encontra profundamente imiscuída na Cultura e mantém a sua influência noutros domínios que não o filosófico. Por exemplo, nessa linha, Michel Onfray, no seu Tratado de Ateologia, classifica de ateísmo cristão o pensamento dos homens oitocentistas que não acreditam na existência de Deus, mas cuja moral se rege pelos valores do cristianismo.

No caso de Pessanha - também porque a sua poesia mergulha "as suas raízes no húmus natal" - existirá, não uma moral cristã, mas uma estética primeva que não dispensa uma concepção divina, um plano do mundo. É, sobretudo, em termos estéticos, imagéticos até, com todas as suas consequências, que esses arquétipos assombram Pessanha. Ele recorre aos mitemas da sua cultura, claramente perturbantes, para exprimir o seu desvanecimento no mundo contemporâneo e também na sua própria sensibilidade. Tal procedimento é recorrente quando o poeta se refere, por exemplo, a figuras femininas, segregando imagens como "Magra figura de vitral...", "Madalena, cabelos de rastos...", de nítida influência religiosa ou, num registo mais rural, mas igualmente irreal: a alma de sua mãe, pela neve, a mendigar à porta dos casais.

Repare-se ainda no poema "Transfiguração": 
Mulher forte, remiu-me a tua prece:

Penitente, pagão, bem lusitano

Ergo os braços ao céu quando anoitece.

Judas divaga, em espiras de pecado

Eis-me o Verbo de Deus, sacramentado

No rebuço dum capote alentejano.

A mulher (origem, cultura) fica como repositório da crença, que eventualmente, à la Pascal, o redimirá. Mas ele é Judas (traidor, em pecado) e, mesmo quando poeta, expressão divina, "sacramentado", acaba rebaixado à banal, prosaica, desencantada condição de existência "no rebuço dum capote alentejano".

\section{Fusão ou barbárie}

Uma das consequências principais de um universo dessacralizado é o surgimento da morte como espaço de dissolução do indivíduo. Deus existiu moribundo na poesia do século XIX, até encontrar a sua mais desesperada e última expressão no satanismo, que precedeu o nosso poeta. Tais caminhos mostraram ser becos sem saída, meras expressões contingentes de um problema que cavava mais profundo que uma inversão, na qual, afinal, se declarava um amor supremo edipianizado.

E não seria por aí que Camilo caminharia. Como refere Rubim (1993), a partir da crítica do poeta ao livro Flores de Coral, de Alberto Osório de Castro, nele a vida surge como "uma consequência lógica" da morte, a vida significa a morte, uma não é a negação da outra. "De que havia pois de lamentar-se, ou contra o que havia, pois, de insurgir-se, se a morte é, em relação à vida, não só o termo fatal, mas também a consequência lógica?”. 
Contudo, Pessanha não deixa de considerar a morte como algo de fatal, a par com uma consequência lógica. Daqui se entende a concepção da vida - apenas porque no humano existe à partida o conhecimento antecipado do fim - como fatalidade, embora esteja ausente o destino. O que parece aconchegar tal concepção da morte como dissolução do indivíduo, em que esta não passa de uma "consequência lógica da vida", parece ser um desejo último de fusão com o Cosmos, finalmente de participação total, expurgadas que serão a consciência e a dor.

Recortes vivos das areias,

Tomai o meu corpo e abride-lhe as veias...

O meu sangue entornai-o,

Difundi-o sob o rútilo sol [...].

Só o meu crânio, fique,

Rolando, insepulto no areal,

Ao abandono do simoun

Que o sol e o sal o purifique.

A morte será uma porta para a integração total no universo, integração que não será a de uma alma una mas da matéria que se transforma, de um corpo que se desfaz: "Róseas unhinhas que a maré partira... / Dentinhos que o vaivém desgastara... / Conchas, pedrinhas, pedacinhos de ossos..." é o que sobra de uma vida e da "fúlgida visão, linda mentira!". Poderá ser correcto afirmar que a biografia infantil do poeta, as suas desilusões amorosas e mesmo a sua frágil saúde terão sido razões importante para conferir à dor um lugar de relevância nos seus poemas. Mas creio que, aquém e além das referências biográficas, fará sentido outorgar a essa dor metafísica - consequência da cons- 
ciência da inexistência de Deus, do indivíduo após a morte e do Destino - um papel central na obra do poeta de Clepsidra.

\section{A dor que deveras sente}

De tal modo a questão da dor é central na poesia de Camilo Pessanha que o poeta a transforma em energia necessária, como se ela fosse o único instrumento que permitiria uma visão mais profunda do universo e, de um modo quase perverso, justificasse a existência humana: uma espécie de Sofro, logo existo, na medida em que seria um garante de Ser.

Tenho sonhos cruéis: n’alma doente

Sinto um vago receio prematuro.

Vou a medo na aresta do futuro,

Embebido em saudades do presente...

Saudades desta dor que em vão procuro

Do peito afugentar bem rudemente,

Devendo ao desmaiar sobre o poente,

Cobrir-me o coração dum véu escuro!...

Porque a dor, esta falta de harmonia, Toda a luz desgrenhada que alumia

As almas doidamente, o céu de agora,

Sem ela o coração é quase nada:

- Um sol onde expirasse a madrugada,

Porque é só madrugada quando chora. 
Sem a dor, o coração, os tais sonhos, "é quase nada". São as lágrimas que justificam a madrugada e sem elas o sol não seria sol, nele se extinguiria o que ele próprio proporciona. A importância atribuída à falta de harmonia remete para a frase de Rimbaud: "Finalmente, acabei por considerar sagrada a desordem do meu espírito". No caso do poeta português, essa desordem é fruto da dor, mas é também fonte de iluminação, de uma percepção outra do mundo, como se fora um método poético de absorção mais intensa das coisas. Este poema é de 1888. Mais tarde, o poeta acabaria por rever essa posição como adiante demonstraremos.

Ora a questão da dor fora colocada no debate filosófico, entre outros, por Soren Kierkegaard e por Nietzsche, que, na sua Genealogia da moral, a refere como a grande criadora de memória. O filósofo alemão evoca os grandes espectáculos públicos da dor: as matanças, as carnificinas, as execuções públicas e a tortura, a que a Humanidade tem paulatinamente assistido e cuja função, afirma, é precisamente a criação de uma memória; a dor como uma terrível mnemotécnica, que passa mesmo, em certas sociedades, por rituais extremos e pela inscrição dos corpos.

Num plano individual, a dor também proporciona a memória e demarca os limites de acção dos indivíduos, mas a sua persistência, nomeadamente de uma dor metafísica, impele o sujeito para a reflexão filosófica e - pretenderão alguns - estende o campo de percepção a outras realidades. Tal fará, em Pessanha, que a dor seja invocada: "Saudades desta dor que em vão procuro/ Do peito afugentar bem rudemente". Repare-se no paradoxo: sente-se a falta (heurística) de uma dor que se pretende eliminar, porque ela é "a luz desgrenhada que alumia as almas" e o "céu d'agora". Ou seja, a dor é ainda o que permite, no caos que desencadeia, um determinado conhecimento de si próprio e a intuição do universo. 
Veja-se o exemplo do poema "Branco e Vermelho", no qual a dor se transmuta em luz, em lúcida febre e proporciona a visão, a contemplação do mundo. E é toda uma humanidade agrilhoada que o poeta nos descreve, atravessando um mundo deserto, futilmente explorada e temente de um castigo, seres viventes nos charcos do medo, que só a morte liberta do sofrimento.

A dor induz o poeta a um estado de luminosidade/alucinação que lhe proporciona a visão da humanidade que desfila, açoitada ao ritmo dos seus versos. E que humanidade é essa? Um grande painel de sofrimento, de desconforto metafísico e também produto do crime cometido desde o alvorecer da História: a exploração do homem pelo homem.

Claro que neste poema existem outros cambiantes, outros caminhos interpretativos, nomeadamente (uma vez mais) para quem se quiser referir a conhecimentos esotéricos e à importância do maniqueísmo (a oposição luz/trevas) no pensamento templário e maçónico, sabida que é a filiação de Pessanha à maçonaria. Contudo, cremos que esta filiação, longe de ser religiosa, passava precisamente pela recusa da Igreja e por uma tendência de fraternidade social. É sabido em Macau que a loja a que Pessanha pertencia não tinha um carácter teísta, bem pelo contrário. Dela fizeram parte conhecidos ateus e republicanos.

\section{Alma lânguida e inerme}

À medida que em Macau Pessanha vai adensando os seus contactos com o pensamento chinês, podemos vislumbrar nos seus poemas alguns pontos de contacto com a tradição oriental, nomeadamente eventuais influências daoistas. De facto, a concepção de um mundo heraclitiano, em permanente movimento, não andará muito longe da ontologia proposta pelo 
pensamento daoista, mas será sobretudo o retorno à pureza original, que todo o pensamento clássico chinês prescreve, que encontra nos daoistas um método que nos surge como próximo de certos versos do nosso poeta.

Para o sábio daoísta, deve o homem retirar-se do mundo, afastar-se para o ventre da terra onde, no silêncio, num processo de metamorfoses, comparável ao de uma crisálida, se transformará no Feto Imortal. O daoista alimentar-se-á na sua gruta, sugando as estalactites, como se fossem os seios da Terra.

Pessanha abre precisamente a "Clepsidra" como o famoso poema "Inscrição":

Eu vi a luz em um país perdido.

A minha alma é lânguida e inerme.

Ó! Quem pudesse deslizar sem ruído!

No chão sumir-se, como faz um verme...

Ou mais à frente no mesmo volume:

Porque o melhor, enfim,

É não ouvir nem ver...

Passarem sobre mim

E nada me doer!

- Sorrindo interiormente,

Co'as pálpebras cerradas,

Às águas da torrente

Já tão longe passadas. -

Rixas, tumultos, lutas,

Não me fazerem dano...

Alheio às vãs labutas,

Às estações do ano. 
Passar o estio, o outono,

A poda, a cava, e a redra,

$\mathrm{E}$ eu dormindo um sono

Debaixo duma pedra.

$[\ldots]$

E eu sob a terra firme,

Compacta, recalcada,

Muito quietinho. A rir-me

De não me doer nada.

Ora não se trata aqui da morte mas de atingir um estado outro de consciência, em que a fusão com a Terra, que um psicanalista poderia atribuir a um desejo de fusão com a mãe, seria o passo principal para conseguir um determinado tipo de repouso, que eliminaria a dor.

Gaston Bachelard, curiosamente no mesmo livro em que refere Lúcio Pinheiro dos Santos, um filósofo amigo do poeta de Macau, entende

[...] o repouso como um dos elementos do devir", que se inscreve no "cerne do ser, que devemos mesmo senti-lo no fundo mesmo do nosso ser, ao nível da realidade temporal sobre a qual se apoiam a nossa consciência e a nossa pessoa. [...] Que cada um, à sua maneira, se liberte das excitações de circunstância que o põem fora de si. [...] o ser libertar-se-á de um impulso vital que o afasta para longe dos objectivos individuais, que se desgasta em actuações imitadas. [...] A consciência pura aparecer-nos-á como uma potência de espera e vigia, como uma liberdade e uma vontade de nada fazer. (BACHELARD, 2006, V-VI) 
Estamos então perante uma espécie de quietismo como panaceia para a dor, fonte de iluminação e, no sentido referido por Gustavo Rubim, de alucinação, na medida em que a percepção do mundo se altera, se refina, se torna rítmica através da escuta aproximada do pulsar do pensamento e da própria matéria. Também nessa crisálida emerge, finalmente, um fio de voz, plena de consciência e de musicalidade, que dará origem ao poema. Não se trata, portanto, de um desejo de morte mas de obter um lugar excelso de compreensão do mundo que passa, como no daoísmo, pela participação no todo, quase mineralização, onde a impessoalidade não significa necessariamente despersonalização mas, pelo contrário, a formação de um ser outro, como a borboleta Aurelia dos neo-platónicos de Alexandria, símbolo de uma nova sabedoria.

Podemos concluir que o ateísmo de Camilo Pessanha não o conduziu a um beco sem saída, como o poema "Estátua" parecia anunciar. Pelo contrário, permitiu-lhe navegar por territórios desconhecidos, não se fechar na sua própria cultura e dotar a sua poesia de uma universalidade e de uma atemporalidade inegáveis.

Quando nos subtraímos a essa ideia em que tudo cabe e que tudo explica, ficamos sós perante o Cosmos, mas é precisamente nesse momento que se revelam a tragédia e a beleza da condição humana, desse animal cujo dever é olhar o universo de frente, sem improváveis mediações, assumindo-se como filho das estrelas e do mar, assombrado pela ideia de infinito e orgulhoso por ser uma pequena chama no vasto incêndio do universo.

\section{Referências}

Bachelard, Gaston. La dialectique de la durée. Paris: Puf, 2006. 
Dias Miguel, António. Camilo Pessanha: elementos para o estudo da sua biografia e a da sua obra. Edição de Álvaro Pinto (“Ocidente”). Lisboa, 1956.

Lemos, Ester de. A “Clépsidra” de Camilo Pessanha: notas e reflexões. Lisboa: Tavares Martins, 1956.

Nietzsche, Friederich. Genealogia da Moral. Lisboa: Guimarães Editores, 1983.

Novalis. Fragmentos, diálogos monólogos. São Paulo: Iluminuras, 2009.

Onfray, Michel. Tratado de Ateologia. Lisboa: Edições Asa, 2007 Rubim, Gustavo. Experiência da alucinação: Camilo Pessanha e a questão da poesia. Lisboa: Caminho, 1993.

José, Carlos Morais. A dor que deveras sente. In: Simas, Monica (Org.). Estudos sobre Macau e outros orientes. São Paulo: Paulistana, 2017. p. 260-279. 
DOI: 10.4322/85-99829-93-6n

\title{
Pintar Macau e a Ilha dos Amores: José Rodrigues e Luís de Camões (intermedialidades)
}

\author{
Isabel Pires de LIMA ${ }^{1}$
}

Outros muitos [feitos] verias, que os pintores Aqui também por certo pintariam, Mas falta-lhe pincel, faltam-lhe cores; Honra, prémio, favor, que as artes criam (CAmões, Os Lusíadas, VIII, 39)2

A epopeia camoniana escrita à luz dos preceitos da retórica e da arte poética humanistas dará expressão ao secular debate

\footnotetext{
1 Professora Catedrática da Universidade do Porto. Investigadora do Instituto de Literatura Comparada Margarida Losa (Unidade I\&D da FCT). Áreas de especialidade: Literatura Portuguesa Moderna e Contemporânea e Estudos Queirosianos com dezenas de títulos publicados. Trabalha ainda em Estudos Interartísticos e em Literaturas Comparadas em Língua Portuguesa; piresdelimaisabel@gmail.com

2 Todas as citações da obra de Luís de Camões, Os Lusíadas, serão feitas a partir da edição organizada por Manuel dos Santos Alves (1971).
} 
em torno da relação entre pintura e poesia e da presumível superioridade de uma em relação a outra. Desde Simónides, nos séculos IV-V a.C., que a questão se coloca. Terá sido ele o primeiro a definir a pintura como "poesia muda" e a poesia como "pintura que fala", dando início a uma contenda que atravessou os séculos e que explorou as semelhanças e diferenças entre elas e a maior ou menor expressividade de cada uma levando tendencialmente a poesia a melhor. Aristóteles atentará no assunto na Poética, mas terá sido Horácio, na Arte Poética, no século I a.C., que definitivamente lançará as bases da polémica e fixará uma fórmula que se celebrizará até aos dias de hoje como referência no debate desse tipo de questões: "ut pictura poesis" ("como a pintura, assim é a poesia"). Teremos que aguardar pelo romantismo para ver Lessing, em LaoKoon (1766), pôr em causa a possibilidade de uma comparação entre artes de natureza distinta, adoptando critérios de análise similar para objetos bem distintos. Aliás, Lessing usa ironicamente para título do seu livro o nome de uma célebre escultura de Miguel Ângelo inspirada no episódio mítico narrado com imensa expressividade por Virgílio.

Camões, numa reflexão sobre a arte, desenvolvida no Canto VIII (39-42), na qual discorre sobre as condições que a favorecem e sobre as que lhe não são facultadas, refere-se à poesia como a "pintura que fala" (VIII.41), como antes se referira à pintura como "muda poesia" (VII.76). Aliás, pintura aparece aqui também para designar, como era comum na época, toda a forma de arte. Esta reflexão, é curioso lembrá-lo, surge no âmbito da meditação que atravessa Os Lusíadas sobre o herói, ou melhor, sobre o heroísmo, visto que, como nota Maria Vitalina Leal de Matos, Camões desenvolve a esse respeito "uma teoria impessoal, que ninguém personifica; um modelo, o que, aliás, está de acordo com a opção manifestada no título: um herói co- 
lectivo" (SILva, 2011, p. 499) E essa teoria defende a ideia de que não basta pertencer a uma estirpe nobre para se ser herói; implica uma conquista individual e o amor pela cultura - trata-se portanto de um modelo do herói culto.

Vem isto a propósito do facto de Camões não se ter alheado da disputa muito especialmente desenvolvida no seu tempo entre a "pintura que fala" e a "muda poesia", para usar de novo as suas expressões, e de ter dado corpo a uma poesia altamente plástica, a qual, dado o seu pendor descritivo, sobretudo n'Os Lusíadas, dialoga constantemente com o campo da pintura, quer a pintura erudita dos mestres do classicismo, quer com a linguagem da pintura.

Aliás a crítica camoniana, desde o século XIX, tem sido sensível a essa proximidade ${ }^{3}$. Já no presente século, Sara Paleri nota, a propósito de Os Lusíadas, que "Il poema si impone come epopea visiva che narra per far vedere" (PALERI, 2009, p. 14) e cita abundantemente o ponto de vista de Roncaglia, que tem desenvolvido múltiplos estudos reveladores de que Os Lusíadas se constituem como epopeia de excepção através de séries de imagens e cenas justapostas que se articulam com os retratos breves que Camões pinta com palavras, à imagem da mais cuidada pintura renascentista. Concluindo Sara Paleri, no seguimento daquele, que

Camões si tova a 'duettare com gli artisti del Cinquecento, con l'exemplum dei classici, con i colori ed i suoni di un' epopea colta e volutamente "difficile", con l'allegoria decorativa tanto cara ai pittori suoi

3 Cf. Carlos Ascenso André, "Poesia e Pintura na Poesia de Camões", in Dicionário de Luís de Camões (2011, p. 703-707). 
contemporanei, con l'emblema e la visione simbólica (PALeri, 2009, p. 13),

numa rede intertextual intensa com a arte do seu tempo.

Em síntese, a dimensão plástica da poesia de Camões é fortíssima e muitos são os passos d'Os Lusíadas que disso dão testemunho, desde pequenos episódios descritivos, a largos frescos narrativos. A título meramente exemplificativo, lembremos a descrição do escorbuto, terrível doença mortal que atacava os navegantes, no canto V. 81-2, ou a acção das Nereides barrando a entrada da armada em porto perigoso, no canto II.20-2. E toda a gente lembrará os grandes e célebres painéis do retrato de Vénus, no canto II, ou do Adamastor, na canto V, assim como os verdadeiros polípticos constituídos pelos episódios dos Doze de Inglaterra, no canto VI ou da batalha de Ourique, no canto III. Em todos eles, Camões revela uma atenção de artista aos matizes da cor e do brilho, aos contrastes do claro/escuro, ao rigor do pormenor, à expressão do movimento, tudo à maneira da pintura sua contemporânea, cujas temáticas visita. Carlos Ascenso André (2011, p. 705) faz notar a insistente presença, dez vezes acima do que era habitual na época, das ocorrências do verbo ver na epopeia camoniana: 444 ocorrências, só ultrapassado pelo verbo ser, que regista 697. Complementarmente, grande é a frequência de verbos que se reportam ao campo do olhar e de termos do campo das artes plásticas como pincel, pintor, tela, tinta.

Pode-se portanto afirmar com Roncaglia e Sara Paleri que

È possibile intravedere nei colori della pittura e nei colori della retorica camoniana un principio di 'addizione' grazie a cui l'intensità visuale e l' intensità intellettuale 
si legano in un vincolo intenso e inestricabile. (PALERI, 2009, p. 15)

Não admira portanto que a obra de Camões tenha suscitado a atenção de artistas plásticos de todas as épocas, que fizeram de múltiplos frescos da epopeia fonte de inspiração, produzindo obras plásticas nos mais diversos suportes.

E não admira também que o episódio mitológico da Ilha dos Amores com o seu excepcional colorido e a sua extraordinária beleza plástica tenha sido um dos mais desafiantes a esse nível.

$* * * * *$

José Rodrigues, um dos artistas plásticos portugueses que se tem deixado seduzir pelo canto da sereia camoniana, é um dos nomes maiores da cena plástica portuguesa contemporânea, nomeadamente do Porto, em cuja Escola Superior de Belas Artes se formou e onde desde logo se notabilizou a par de Ângelo de Sousa, Armando Alves e Jorge Pinheiro, como um dos "Quatro Vintes", designação que decorreu da classificação de vinte valores obtida pelos quatro nesses avaros anos sessenta. Com diminuta internacionalização para além do espaço lusófono, José Rodrigues é autor de uma vastíssima obra no campo da escultura e da pintura, muito difundida sobretudo a Norte de Portugal, e ajudou a criar um dos espaços artísticos mais significantes dos últimos 50 anos, no Porto, a Cooperativa Árvore, para além da Bienal de Cerveira, que tem lugar numa pequena vila do extremo Norte de Portugal, um dos primeiros exercícios de descentralização das artes plásticas contemporâneas em Portugal.

Desde os anos de 1960 até aos dias de hoje, José Rodrigues vem desenvolvendo um diálogo estreito com a literatura, em 
grande parte motivada pela intermediação de Eugénio de Andrade, poeta marcante das letras portuguesas da segunda metade do século XX, vizinho portuense e amigo do pintor. Para além do intenso contacto com a literatura contemporânea, José Rodrigues tem também dado corpo plástico ao seu encontro com textos da tradição clássica, de que se destaca, o diálogo com Camões e a epopeia. Para além de ter ilustrado, nos anos 1980, os 10 cantos d'Os Lusíadas, José Rodrigues tem duas séries de desenhos produzidos em décadas diferentes (1980 e 1990), com o título Variações para a Ilha dos Amores (1992), inspiradas nos cantos IX e X da epopeia camoniana. Esses trabalhos estiveram expostos, em 1992, juntamente com os quadros Macau e Camões, na Galeria do Leal Senado de Macau e, no ano seguinte, no Convento da Orada em Monsaraz (Alentejo). Daqueles trabalhos, os produzidos na década de 90, e apenas esses, foram também expostos em 1993 no Porto, no Espaço d'Arte TLP, com o título Fragmentos para uma Ilha dos Amores (1993).

A minha atenção irá deter-se nos referidos trabalhos inspirados pelo episódio camoniano da Ilha dos Amores, remetendo para outra oportunidade aqueloutros que ilustram os X cantos d'Os Lusíadas. A série de trabalhos dos nos 1980 (doravante identificados pela numeração de 1 a 14) é substancialmente diferente da da década de 1990 (doravante identificada pela numeração de 15 a 31); os primeiros são depuradas grafites sobre papel; os segundos são trabalhos em carvão e pastel sobre papel sobre tela, nos quais a componente figurativa é mais impositiva, a par de uma certa tonalidade expressionista, como a visualização exemplificativa de dois ou três trabalhos facilmente evidencia. Ora aquela primeira série é acompanhada por brevíssimos poemas de Eugénio de Andrade num diálogo inter-semiótico que envolve afinal um artista plástico e dois poetas (Camões e Eugénio de 
Andrade); o mesmo acontece de resto com a segunda série, cuja edição do catálogo abre com o poema, "a sua dinamene", do poeta nosso contemporâneo, Vasco Graça Moura, o qual entra ainda num jogo intertextual com a lírica camoniana. Dinamane terá sido uma escrava chinesa pela qual Camões se terá apaixonado e que imortalizou na sua poesia.

Acresce que essa série de trabalhos da década de 1990 inclui também alguns quadros que, pese embora o título do catálogo, Fragmentos para uma Ilha dos Amores, verdadeiramente extravasam o referido episódio, com evidentes alusões à saga da viagem marítima que a epopeia relata e à figura de Camões na sua relação com o Oriente, o Índico e a epopeia propriamente dita. Dos três quadros (16-17-26) que aludem a Camões, dois remetem para episódios biográficos atribuídos ao poeta: a sua relação amorosa com Dinamene com quem se terá refugiado na famosa gruta macaense (16) e o naufrágio que terá sofrido na viagem de regresso da Índia onde terá perdido a amada, um olho e terá estado prestes a perder o seu livro (26), Os Lusíadas; o terceiro quadro é um retrato de glorificação (17) mas, digamos assim, de glorificação trágica.

Trata-se de um Camões envelhecido e bastante despojado, monocromático, com um certo ar de ermita no deserto, magro e triste, embora altivo, empunhando a sua glória em primeiro plano, bem no centro, o livro do seu canto vitorioso. Aliás, nos outros dois quadros, também o livro lhe ocupa as mãos. Emoldura o retrato o ícone por excelência do estilo manuelino e que está presente de resto em diversos quadros dessa série, a corda e os nós da arte de marear. É portanto um estratagema de glorificação pelo qual o pintor optou. Por trás da moldura, uma espécie de linha de um horizonte costeiro, entre mar e terra, espaço de entre dois que camões sempre ocupou, como Graça Moura 
lembra na parte 5 do referido poema, que citaremos adiante. Em fundo e do lado esquerdo do rosto, uma estrela de cinco pontas alude ao signo venusiano sob o qual Camões viveu. Ora o pentagrama é um símbolo associado desde a Antiguidade à deusa Vénus e por extensão à própria representação no firmamento do planeta Vénus, isto para além de outras simbologias como por exemplo a de infinito. Aliás, noutros quadros da série, a estrela de cinco pontas aparece de modo mais camuflado ou mais explícito (15-21-24), indiciando a protecção de Vénus que acompanha a aventura marítima do Gama desde o início e muito especialmente marca presença de favorecimento e intermediação no episódio da Ilha dos Amores.

A representação de Dinamene e Camões naquilo que parece ser uma gruta (16) é atravessada por uma espécie de lirismo trágico, digamos assim. Se, por um lado, Camões contempla amorosamente a sua Dinamene desvelada e de sensuais mamilos proeminentes, em atitude próxima da evocada pelo poema de Vasco Graça Moura:

ao princípio era a ninfa dormindo-se, e a ninfa era uma moça china chamada dinameme, com quem vinha embarcado. ali ficava, reclinada e nua, a deixar-se lentamente contemplar; (Rodrigues, 1993, p. 15)

por outro lado, quer o seu rosto, quer o da amada, transmitem uma apreensão trágica, que os seguintes versos do mesmo poema dizem:

ao princípio era a ninfa adormecida e sem cendal ao princípio era a ninfa que depois naufragou, 
a que depois foi lastro de todos os navios.

(Rodrigues, 1993, p. 15)

A própria gruta sugere uma certa ameaça de sucção, como ameaçador e premonitório de amputação é aquele braço fantasmático de Camões.

O terceiro desses três quadros (26) confirma a amputação. Trata-se de uma clara alusão ao naufrágio de Camões no Índico no qual perdeu a sua Dinamene, episódio por ele recordado nos doloridos sonetos "Ah! minha Dinamene! Assim deixaste" e "Quando de minhas mágoas a comprida"4 e que a parte 5 do poema de Graça Moura evoca:
a sua dinamene, a pobre moça china,
ei-la cativa entre nenúfares brancos e tufos de junquilhos.
o seu corpo é uma inquieta deslembrança,
e de plácidas águas se faz agora o seu regaço.

4 Trata-se dos seguintes poemas:

"Ah! minha Dinamene! Assim deixaste/Quem não deixara nunca de querer-te!/Ah! Ninfa minha, já não posso ver-te,/Tão asinha esta vida desprezaste!//Como já pera sempre te apartaste/De quem tão longe estava de perder-te?/Puderam estas ondas defender-te/Que não visses quem tanto magoaste?//Nem falar-te somente a dura Morte/Me deixou, que tão cedo o negro manto/Em teus olhos deitado consentiste!//Oh mar! oh céu! oh minha escura sorte!/Que pena sentirei que valha tanto,/Que inda tenha por pouco viver triste?" (CAMÕEs, 1971, p. 230)

"Quando de minhas mágoas a comprida/Maginação os olhos me adormece,/Em sonhos aquela alma me aparece/Que pera mim foi sonho nesta vida.//Lá nua saudade, onde estendida/A vista pelo campo desfalece,/Corro pera ela; e ela então parece/Que mais de mim se alonga, compelida.//Brado: - Não me fujais, sombra benina! -/Ela, os olhos em mim c'um brando pejo,/Como quem diz que já não pode ser,//Torna a fugir-me; e eu gritando: - Dina.../Antes que diga: -- mene, acordo, e vejo/Que nem um breve engano posso ter." (CAMÕES, 1971, p. 192) 
vi, claramente vista, aquela ninfa.

e vi grutas e nuvens, revoltas sonoridades, águas transparentes, calcários, conchas, pedrinhas, pedacinhos de ossos, estrelas do mar, ânforas do esquecimento, fragmentos do canto a escapar sob a linfa clara.

e também a linha da costa, o recorte das fortalezas, os procelosos baixos, os sinais da terra e os sinais do firmamento,

e outros sinais do mar, e os náufragos por socorrer, tanto corpo por enterrar, tanta mágoa por reparar, tanto cabo por dobrar,

tanto nó, tanto dó, tanta paixão, tanto infortúnio, tanta cobiça, tanta ventura, tanto dano. (Rodrigues, 1993, p. 17)

O clima de catástrofe é dado pelos símbolos convocados no lado esquerdo do quadro, a corda quebrada e subitamente espiralada que a figura de Camões percepciona como ameaça a evitar do mesmo modo que essa força em forma de foice que parece querer engolir o poeta. Um outro quadro que alude à tragédia do naufrágio (22) também declina a experiência do desencontro.

$* * * * *$

Mas atentemos então no longo episódio celebrizado pela designação de Ilha dos Amores, que se estende da estância 18 do canto IX até a 143 do canto X (cerca de 20\% do poema) e que decorre numa ilha imaginada e imaginária, nunca assim denominada pelo poeta, que a designa primeiro "ínsula divina" (IX.21) e por fim "Ilha alegre e namorada" (X.143), classificando-a ainda de fresca, bela, formosa, alegre, angélica, e de "Ilha 
de Vénus" (IX.95). A denominação estabelecida pela tradição decorre do facto de nela ser facultada pelos deuses," (I.2), através da experiência do amor. $\mathrm{O}$ episódio em causa origina um hino ao amor como valor humano conquistado por merecimento e cuja mais exactamente por Vénus, aos nautas, a recompensa pelas suas "obras valerosas consecução abre as portas de um novo mundo, de uma nova era.

Ao ser iniciada a viagem de regresso, Vénus, a "Deusa Cípria" (de Chipre) quer premiar os nautas pelos longos trabalhos que lhes permitiram a glória de chegar à Índia, circum-navegando África (IX.18) e ordena ao seu filho Cupido que entre em acção; ele que "Os deuses faz descer ao vil terreno / E os humanos subir ao Céu sereno.”(IX.20), isto é, que aproxima homens e deuses, no caso nautas e ninfas. A ilha que os nautas avistam e para onde serão conduzidos por "aquáticas donzelas [...] - Todas as que têm o título de belas, / Glória dos olhos, dor dos corações - " (IX.22) será uma ilha imaginária cuja tentativa de identificação tem feito correr rios de tinta dos exegetas camonianos.

Trata-se de uma ilha que o texto camoniano permite localizar no Índico, visto que a frota do Gama está a iniciar a viagem de regresso, mas que na verdade corresponde ao topos clássico do locus amoenus aproximável de uma ilha mediterrânica. Com Vítor Aguiar e Silva, podemos sintetizá-la desse modo:

É uma ilha fresca e bela, recoberta de gramineo verde, onde limpidas fontes correm por entre verdura e pedras alvas. Verde do arvoredo e da relva e brilho cristalino das águas correntes ou represadas - eis os dois tons cromáticos que invadem a paisagem. Depois, numa profusão de perfumes e cores, o poeta pormenoriza e 
faz avultar os outros elementos que perfazem o quadro do locus amoenus: frutos variegados, árvores e flores, muitas delas dotadas de significado simbólico e mítico, cânticos de aves, velozes e elegantes animais de caça... E a coroar a beleza deste paraíso terreal, o bando das ninfas nuas ou semidesnudadas, tangendo cítaras, harpas, flautas, perseguindo, em fingida corrida venatória, veados, lebres ou frágeis gazelas, ou banhando os esplêndidos corpos nas águas argênteas. (SIlva, 1994, p. 135)

Esse locus amoenus transforma-se em verdadeira Ilha dos Amores pelo encontro nupcial das ninfas e dos nautas, configurando também um locus eroticus. Ouçamos essas duas esclarecedoras e belas estâncias camonianas:

Oh! Que famintos beijos na floresta,

E que mimoso choro que soava!

Que afagos tão suaves! Que ira honesta,

Que em risinhos alegres se tornava!

O que mais passam na manhã e na sesta,

Que Vénus com prazeres inflamava,

Melhor é experimentá-lo que julgá-lo,

Mas julgue-o quem não pode experimentá-lo.

Desta arte, enfim, conformes já as fermosas

Ninfas co'os seus amados navegantes,

Os ornam de capelas deleitosas,

De louro e de ouro e flores abundantes.

As mãos alvas lhe davam como esposas;

Com palavras formais e estipulantes, 
Se prometem eterna companhia,

Em vida e morte, de honra e alegria. (IX.83-4)

Tal rito nupcial, que se estenderá ao próprio Gama com a deusa Tétis, esposa do Oceano, a qual o fará subir a altaneiros paços de "cristal" e "ouro puro e fino", passando com ele grande parte do dia "Em doces jogos e em prazer contino." (IX.87), corporiza o princípio neoplatónico do amor enquanto fonte de regeneração. O quadro (31), da série dos anos 1990, um dos mais figurativos da série, sobretudo no que à figura do Gama diz respeito, dá o clima de fruição erótica continuada e múltipla oferecida por Tétis, mulher carnal e humana, de rosto identificável e princípio arquetípico do feminino, anja sem rosto que acompanhará eternamente Vasco da Gama como as Ninfas seguirão para sempre os nautas lusos. A cor que domina esse quadro mais que todos os outros indiciará essa plenitude alcançada: terra, mar, ilha, espaço sideral confluem rodeando o Gama e com ele o futuro dos portugueses.

Com efeito, esse rito nupcial regenerador propiciará o cumprimento do desejo manifestado por Vénus a Cupido, quando lhe ordena que faça as Nereides apaixonarem-se pelos Lusitanos: "Quero que haja no Reino neptuniano, / Onde eu nasci, progénie forte e bela" (IX.42). No seio lustral das águas que simbolizam o poder genesíaco primordial, nascerá um mundo novo, oposto ao "mundo vil, malino" que desconhece o amor. Uma geração de homens novos, há-de instaurar uma ordem nova, confirmando-se e anunciando-se assim a missão ecuménica do povo português. E veja-se desde já como um dos trabalhos de José Rodrigues, da série da década de 90 - (23) - dá expressão simbólica a essa dimensão ecuménica atribuída aos nautas pela deusa: um cordame da arte de marear engloba todo o universo, como a 
inclusão da rosa-dos-ventos encimando o desenho sugere, terra e mar unidos sob um símbolo cristão de paz e renovação, a pomba e ramo de oliveira ${ }^{5}$.

A corroborar o anúncio desse mundo novo está o desvelamento da máquina do mundo que no seu palácio cristalino Tétis fará ao Gama, após ter ascendido a um "monte espesso" por "um mato / Árduo, difícil, duro a humano trato"(IX.76), ascensão que obviamente simboliza o esforço do conhecimento e da prossecução da virtude:

Dando-lhe a entender que ali viera

Por alta influição do imóbil Fado

Para lhe descobrir, da unida Esfera

Da terra imensa e mar não navegado,

Os segredos, por alta profecia.

O que esta sua nação só merecia,

Tomando-o pela mão, o leva e guia

Para o cume dum monte alto e divino,

No qual uma rica fábrica se erguia

De cristal toda e de ouro puro e fino. (IX.86-7)

Essa célebre cena talvez seja a que origina o desenho - (21) -, aquele que dessas duas séries de José Rodrigues segue mais de perto o texto camoniano, o qual, aliás, acresce a seguinte precisão:

Não andam muito que no erguido monte

Se acharam, onde um campo se esmaltava

5 Noé, para se certificar do fim do Dilúvio, solta uma pomba que regressa com um ramo de oliveira no bico, anunciando o início de outra era de paz. 
De esmeraldas, rubis, tais que presume

A vista que divino chão pisava.

Aqui, um globo vêem no ar, que o lume

Claríssimo por ele penetrava,

De modo que o seu centro está evidente,

Como a sua superfície, claramente.

(X.77)

Trata-se com efeito de uma cena com uma força alegórica evidente e com uma acentuada propensão visual. $\mathrm{O}$ pintor coloca frente a frente a deusa e o Gama, num patamar que os iguala e no seio de uma espécie de divina esfera cristalina e sideral, insinuando uma atmosfera de profecias desenhada por uma linha costeira com a forma do universo. Dentro dela, dois outros mundos se concentram: o mundo que a deusa oferece e revela ao Gama na sua perfeição e totalidade absolutas e um outro mundo imperfeito na sua incompletude, dada pela corda de marear que não se fecha em círculo e por essa linha territorial em aberto, e também mundo imperfeito, nos desastres que pressupõe, sugeridos pela caravela invertida. A tudo preside em lugar central e de destaque o mesmo pentagrama na sua simbologia venusiana já aludida. Pentagrama que se destaca também na imagem (15) que parece mostrar o nauta anónimo (o Zé ninguém português) posto em descanso e em espanto perante o que lhe foi dado desfrutar junto das Ninfas e vislumbrar perante a revelação de Tétis, que a todos incitara - "tu [Gama] c'os mais" - a verem "co'os olhos corporais" (X.76).

O episódio da Ilha dos Amores tem pois no canto camoniano uma função alegórica, que aliás o próprio Camões um pouco surpreendentemente revela ${ }^{6}$, e uma função utópica, ao

6 Diz ele: "Que as Ninfas do Oceano tão fermosas, / Tétis e a Ilha angélica pintada, 
corporizar nos referidos esponsais a energia transformadora do ser e do mundo ${ }^{7}$.

\section{$* * * * *$}

Retomemos agora de modo mais detalhado a intermediação do episódio camoniano com a pintura de José Rodrigues, não sem citarmos mais uma vez Sara Paleri que lembra com muita propriedade que:

Camões afferma explicitamente che quest'isola è stata creata da Venere, l'isola è un dipinto della dea. E all'atto del dipingere e dell'ornare si rimanda continuamente: la "branca areia / pintou de ruivas conchas Citereia", l' "arvoredo gentil" che pende sul lago si specchia nel "cristal resplandecente / que em si o está pintando propriamente"; le ciliegie sono "purpúreas na pintura".

Ache Zefiro e Flora dipingono, e dipingono coi colori delle poesia:

Pintando estava ali Zéfiro e Flora

As violas da cor dos amadores,

\footnotetext{
/ Outra cousa não é que as deleitosas / Honras que a vida fazem sublimada. / Aquelas preminências gloriosas, / Os triunfos, a fronte coroada / De palma e louro, a glória e maravilha, / Estes são os deleites desta ilha.” (IX.89)

7 Cf. a este respeito a excelente leitura de Vítor Aguiar e Silva, intitulada "Imaginação e pensamento utópicos no episódio da «Ilha dos Amores»", no qual defende a sua dimensão utópica em função do conceito blochiano de utopia: "Na paisagem esplendorosamente erótica da ilha $[\ldots]$, os nautas descobrem, para usar as palavras de Bloch, «a paisagem do desejo ante rem, a própria mulher como paisagem que espera». O desejo e o amor abrem o horizonte da esperança e semeiam o futuro. A progénie forte e bela anunciada por Vénus será a encarnação da utopia como energia transformadora do ser.” (SiLvA, 1994, p. 152)
} 
O lírio roxo, a fresca rosa bela,

Qual reluze nas faces da donzela (IX.61)

Così, proprio mentre dipinge, la poesia si limita ad alludere al cromatismo della pittura - che contrae ad alcuni elementi selezionati -, perché quei colori splendano per colorare l'idea più che la realtà." (PALERI, 2009, p. 113)

Poderíamos dizer, recorrendo às palavras da ensaísta, que os trabalhos de José Rodrigues da década de 80 e as palavras de Eugénio de Andrade que os acompanham tomaram a "pintura" camoniana da Ilha dos Amores como uma pintura que pretende mais dar cor à ideia do que à realidade, tendo nós lembrado, como lembrámos, que essa é uma ilha imaginária e alegórica.

Esses desenhos de José Rodrigues são extremamente conceptuais e, não desdenhando alguns elementos figurativos, tendem para a abstracção, como se dialogassem com o texto camoniano naquilo em que ele persegue a construção alegórica. Dito de outro modo, a "pintura que fala" a que Camões recorre para pintar a Ilha dos Amores, modela poeticamente um extraordinário aparato cénico mas que acaba por criar propositadamente a atmosfera rarefeita de uma ilha inexistente, ou seja, que acaba por criar uma alegoria que se torna visível.

Desenhos de José Rodrigues e poemas de Eugénio de Andrade dão essa rarefacção, a depuração mítica que o texto camoniano exige. $\mathrm{O}$ trabalho (8) di-lo de modo exemplar, com essa ilha cristalizada fora da moldura da ilha real mas evanescente que vemos ao fundo, assim como o diz as palavras do poeta ao elencar nomes de várias ilhas da Antiguidade, reais e imaginadas, ilhas habitadas pelo mito e que sendo uma são múltiplas. 
Não será essa a ilha da utopia, das utopias humanas e até divinas?

Aliás, para a mesma ideia de ilha plural remete o texto que acompanha o primeiro desenho da série (2), o qual por seu turno também diz a aludida rarefacção cheia de sentido, atravessada pelo elemento humano do bastão, ceptro, falo (?) que assinala a intervenção, a presença, a coabitação do humano nessa ilha divina. De resto, nesse como em quase todos os quadros da série, temos a exibição desses dois planos que lembram a confluência entre dois mundos que o episódio da Ilha dos Amores descreve, com os deuses a "descer ao vil terreno" e os humanos a "subir ao Céu sereno" (IX.20). O desenho evoca o texto camoniano: "De longe a Ilha viram, fresca e bela, / Que Vénus pelas ondas lha levava" (IX.52), o qual mais adiante acrescenta: "Para lá logo a proa o mar abriu, / Onde a costa fazia uma enseada / Curva e quieta, cuja branca areia / Pintou de ruivas conchas Citereia. // Três fermosos outeiros se mostravam, / Erguidos com soberba graciosa" (IX.53-4). Como o evocam de modo menos explícito os trabalhos (3-5-10) e repectivos textos de Eugénio de Andrade, na medida em que reportam esse momento inaugural do deslumbramento que a descoberta e aproximação da ilha sempre convoca e a esperança de refrigério que comporta.

Talvez importe cruzar estes desenhos com dois da série dos anos 1990, (20-18): o primeiro parecendo evocar a erupção ou a aparição de uma ilha a partir do seio oceânico entre o trajecto da mareação dada pela corda e a linha de costa e convocando as palavras de Vénus quando refere a "Ilha que nas entranhas do profundo / Oceano terei aparelhada" (IX.40); o segundo explicitando a metáfora feminina e erótica, que os versos acima citados: "Três fermosos outeiros se mostravam, / Erguidos com soberba graciosa” (IX.54). Aliás, este trabalho é aproximável na confusão 
que estabelece entre ilha, terra e corpo erótico feminino quer de três outros desta mesma época - (24), (27) e (28) ${ }^{8}$ - quer de um dos desenhos da série dos anos 80 - (6). Este último é acompanhado de dois versos de Eugénio de Andrade - "Corpo ou ilha, colina verde, / prenúncio de aves ou de sede." - que afinal se entretecem com todos estes desenhos e com o próprio episódio camoniano da Ilha dos Amores onde a erotização da natureza atinge tal intensidade que a ilha e corpo das ninfas se con-fundem ou, na formulação de Vítor Aguiar e Silva: "Na paisagem esplendorosamente erótica da ilha [...], os nautas descobrem [...] a paisagem do desejo ante rem, a própria mulher como paisagem que espera" (SiLva, 1994, p. 152).

Diversos desenhos da década de 80 metaforizam de modo sempre depurado, num rigor plástico muito impressivo, a intensidade do encontro amoroso dos nautas e das ninfas que exemplarmente a estrofe 71 (IX) diz:

De uma os cabelos de ouro o vento leva,

Correndo, e da outra as fraldas delicadas;

Acende-se o desejo, que se ceva

Nas alvas carnes, súbito mostradas.

Uma de indústria cai, e já releva,

Com mostras mais macias que indinadas,

Que sobre ela empecendo também caia

Quem a seguiu pela arenosa praia.

8 Os trabalhos (27) e (28) evocam de modo próximo a estrofe 41 (IX): "Ali, com mil refrescos e manjares, / Com vinhos odoríferos e rosas, / Em cristalinos paços singulares, / Fermosos leitos, e elas mais fermosas, / Enfim com mil deleites não vulgares, / Os esperam as Ninfas amorosas, / De amor feridas, para lhe entregarem/Quantas delas os olhos cobiçarem." 
Os desenhos (2-4-7-9) cantam essa fusão regeneradora pronta a fecundar uma "progénie forte e bela" (IX.42) representando a penetração fálica da ilha, a total consubstanciação entre homem e ilha, que o desenho (9) e as palavras de Eugénio de Andrade dizem em plenitude: "Não há ilha / que não seja de amor". O amor, esse "fogo imortal" (IX.42), que Vénus quer ver arder nas águas que domina, é garante das ilhas, espaços da construção de utopias, de um mundo renascido. Na série da década de 90, talvez só o desenho (19) sugira uma metáfora de idêntico sentido com a mútua e consentida entrega desse corpo feminino "oferecido", para usar um adjectivo camoniano posto na boca de Vénus ${ }^{9}$ e esse punho masculino engrinaldado. Há, porém, um trabalho desta última série - (29) - que de um modo mais hermético e simbólico diz aquela íntima fusão: um triângulo dentro do qual ocupa lugar central um nó inextricável e onde os elementos brancos que noutros quadros da série representam o mar, confundem-se com a terra, com a ilha verde. Ora o triângulo é uma forma com alta densidade simbólica muitas vezes aproximada do púbis feminino, mas que por outro lado, quando exibe uma ponta no ar, como é o caso, indica uma polaridade masculina. O desenho remeterá assim também para o rito nupcial que a ilha alberga com a energia e o sentido renovadores a que dará origem e que a forma em flecha do triângulo também aponta.

Serão porém os dois desenhos (12-13), acompanhados das dessoradas palavras de Eugénio de Andrade, que lapidarmente dão a ver a plenitude: manhã inaugural, matéria elementar, luz silente - isto diz o pintor, isto dizem os poetas. É o recomeço do mundo, o começo de um outro mundo. Aliás, a poesia de Eu-

9 Cf. IX.50: "Ali, a fermosa Deusa lhe aconselha / O que ela fez mil vezes, quando amava; / Elas, que vão do doce amor vencidas, / Estão a seu conselho oferecidas." 
génio de Andrade mais uma vez aqui prova como sabe imprimir uma força energética a certas palavras que se tornam capazes de dimanar um excesso, pese embora a limpidez conquistada pela utilização de recursos mínimos, quase à beira da transparência, tal como estes desenhos de José Rodrigues. É o caso, nestes poemas, da palavra luz: "luz inicial", "luz verde", "luz salgada", "luz violeta", "luz dos cardos", "luz calada" ou da própria palavra ilha nas diversas declinações que o poeta dela faz, imprimindo-lhe novos sentidos que permitem o salto do domínio da evidência que os sentidos percepcionam para o domínio da essência, operando um alargamento e uma desocultação do mundo.

O desenho (11), a que ainda não aludimos, através da atmosfera difusa que cria e que parece registar fotograficamente uma realidade fantasmática, uma realidade por vir, não apontará visualmente para a desocultação do mundo a que Tétis procede perante o Gama? E repare-se na distância estética que separa este trabalho altamente abstracto daqueloutro que analisámos acima - (21) - ilustrativo da mesma cena.

Um último quadro reterá a nossa atenção - (25). Deixámo-lo para o fim porque lêmo-lo como uma metáfora do sentido último do episódio da Ilha dos Amores: o domínio do universo, no presente e sobretudo no futuro - terra e mar a norte, a sul, a leste e a oeste, como indicia a rosa-do-ventos no primeiro plano central do quadro - pelos portugueses, "barões de fortes peitos" (X.142), cujos feitos "Divinos os fizeram, sendo humanos"(IX.91). Símbolo desse domínio, confirmado pelo conúbio de humanos e divinos e pela progénie anunciada por Vénus, é o poderoso e inextricável nó de mareação que engloba o universo e abre à esquerda e à direita do quadro para o infinito. 
Iniciámos este trabalho com uma epígrafe proveniente do Canto VII, em que Camões exprime o seguinte lamento perante a falta de cantores, de pintores dos feitos "valerosos" dos portugueses:

Outros muitos [feitos] verias, que os pintores

Aqui também por certo pintariam,

Mas falta-lhe pincel, faltam-lhe cores;

Honra, prémio, favor, que as artes criam (VIII.39)

O trabalho plástico de José Rodrigues recorre a uma acentuada diversidade de processos, patente nas soluções estéticas radicalmente diferentes encontradas para as duas séries de desenhos que aqui trouxemos, uma, muito mais abstractizante e outra muito mais figurativa e simbólica, às vezes com um leve tom expressionista, o que se por um lado abona em favor de José Rodrigues a quem não faltou nem pincel nem cor, para usar a metáfora camoniana, por outro abona em favor da capacidade interpelativa da poesia camoniana mais de quatro séculos volvidos sobre a sua publicação. Com efeito, a polissemia da epopeia de Camões e capacidade por ele manifestada de fazer dela uma "pintura que fala" (VIII.41) têm desafiado artistas visuais ao longo dos séculos, suscitando um intenso diálogo inter-semiótico e numerosíssimas formas de intermediação artística. Tudo isso confirma, a nosso ver, que Os Lusíadas se construíram com sucesso como uma epopeia visual que narra para fazer ver. Trouxeram "Honra, prémio, favor, que as artes criam" a Camões e a todos os que, como José Rodrigues, pela sua intermediação têm sido induzidos à criação artística.

\section{Bibliografia}

André, Carlos Ascenso. Poesia e Pintura na Poesia de Camões. In: Silva, Vitor Aguiar e Coord.). Dicionário de Luís de Camões. 
Alfragide: Caminho, 2011.p. 703-707.

Camões, Luís de. Os Lusíadas. 4. ed. Lisboa: Instituto Camões, 2000. [Leitura, prefácio e notas de Álvaro Júlio da Costa Pimpão / Apresentação de Aníbal Pinto de Casto]

Camões, Luís de. Os Lusíadas. Porto: Livraria Figueirinhas, 1982. [Ilustrações de José Rodrigues em papel IOR]

Gamões, Luís de. Lírica. Círculo de Leitores, 1973. [Prefácio e notas de Hernâni Cidade]

Camões, Luís de. Os Lusíadas. Mafra: Parceria A. M. Pereira, 1971. [Edição com dicionário organizado por Manuel dos Santos Alves]

PALeri, Sara. Os Lusíadas di Camões: ut pictura poësis. Modena: Mucchi Editore, 2009.

Rodrigues, José. Fragmentos para uma Ilha dos Amores. Porto: Espaço d'Arte TLP/Árvore - CCA, 1993.

Rodrigues, José. Variações para a Ilha dos Amores. Macau: Leal Senado de Macau / Serviços Recreativos Culturais, 1992.

Silva, Vítor Aguiar. Camões: Labirintos e Fascínios. Lisboa: Cotovia, 1994.

Silva, Vítor Aguiar (coord.). Dicionário de Luís de Camões. Alfragide: Caminho, 2011.

SoAres, Maria Leonor Barbosa. José Rodrigues - Traduções do ser apaziguando o tempo: Vertentes e modos de um percurso. 4 v. Tese (Doutoramento) - Faculdade de Letras da Universidade do Porto, Porto, 2010. 
Pintar Macau e a Ilha dos Amores...

\section{Imagens}

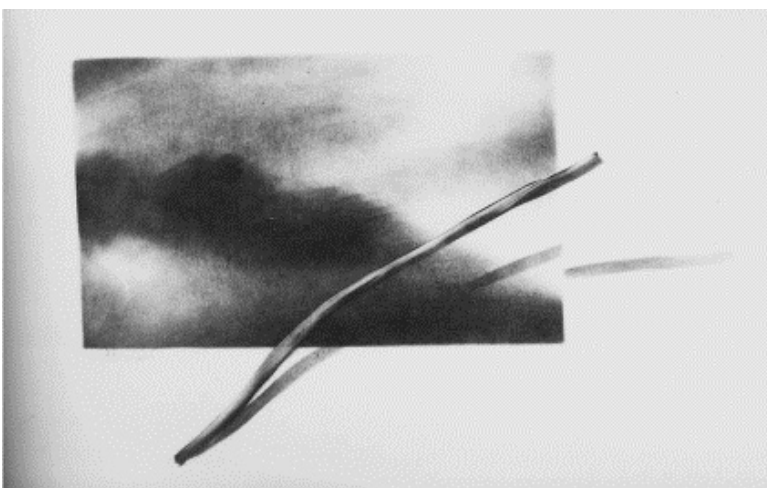

Misteriosa,

a primeira ilha,

a última, voluptuosa.

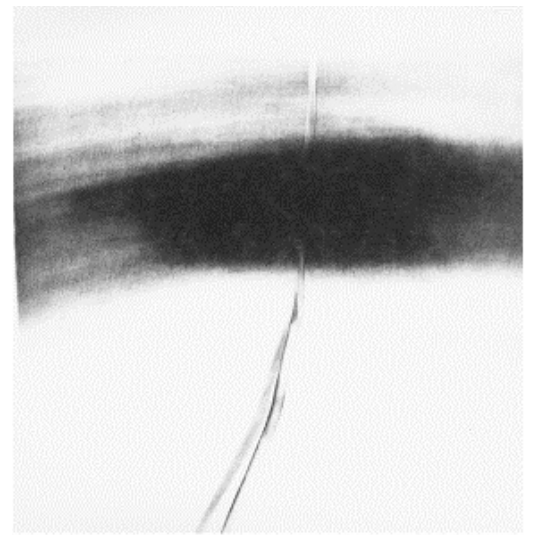

Luz inicial:

rouxinol de espuma. 


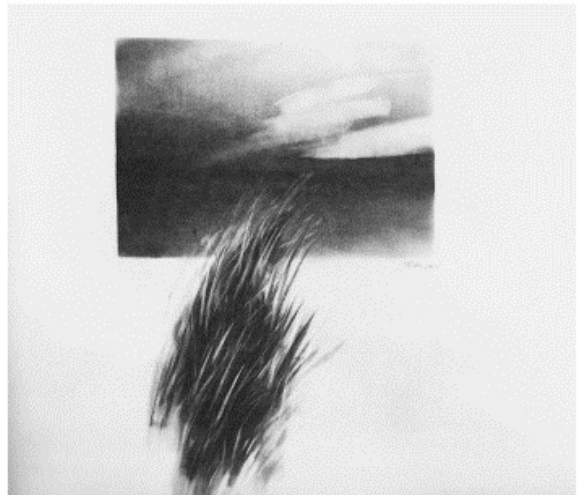

Ilha, de vaga em vaga, branca e bárbara.

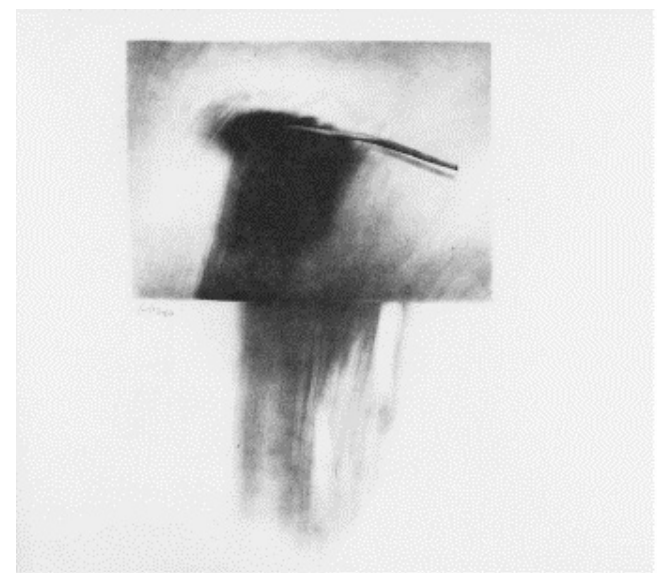

Luz verde das ilhas

jamais anoitecida. 
Pintar Macau e a Ilha dos Amores...

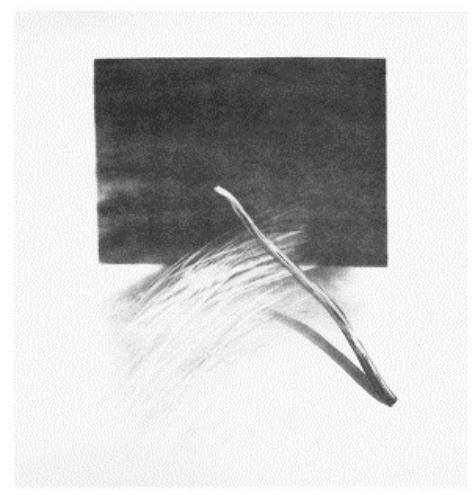

Aproximação da ilha:

luz salgada matutina

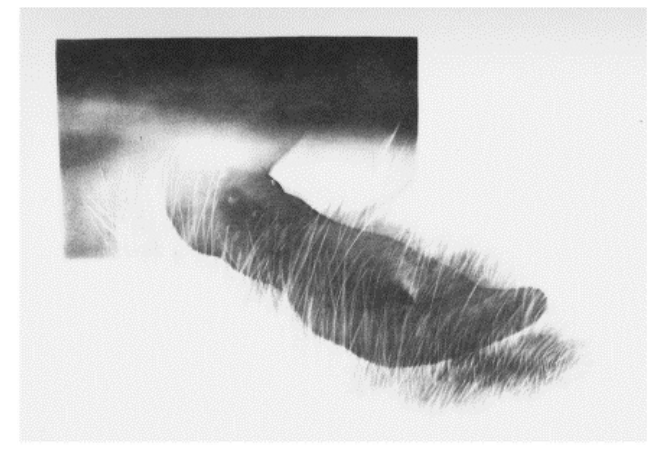

Corpo ou ilha, colina verde, prenúncio de aves ou de sede. 


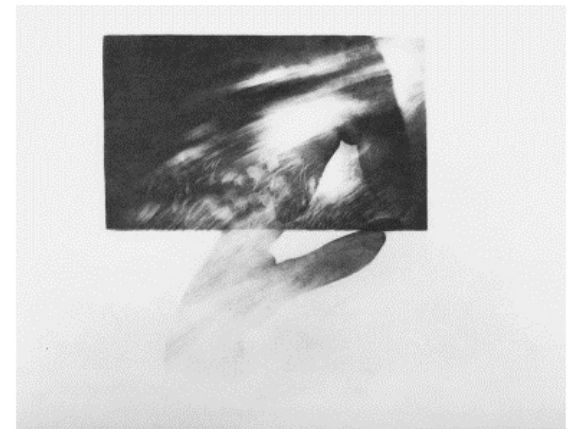

Todo homem é ilha.

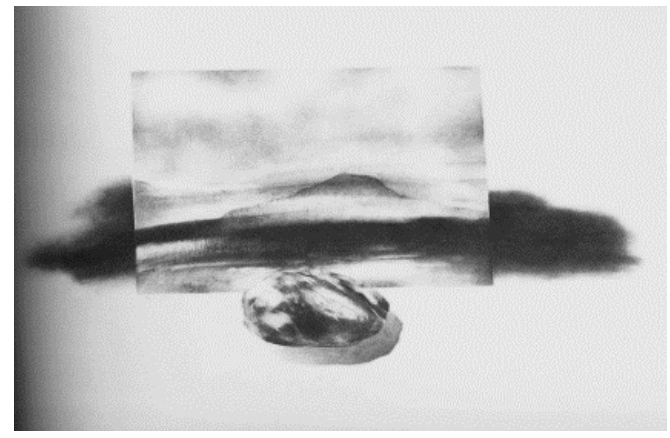

Ítaca, Skiros, Hidra;

Lesbos, Egina, Creta;

Naxos, Santorin, Kerkira. 
Pintar Macau e a Ilha dos Amores...

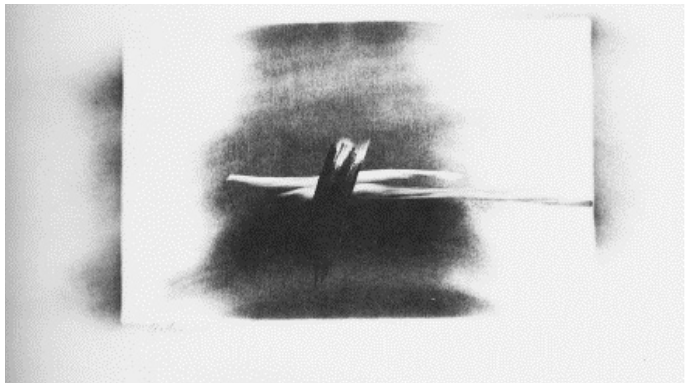

Não há ilha

que não seja de amor.

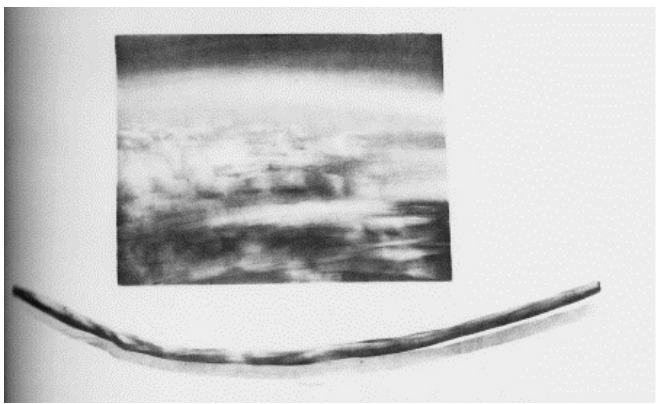

Há amigos que são um bosque no verão - assim as ilhas. 


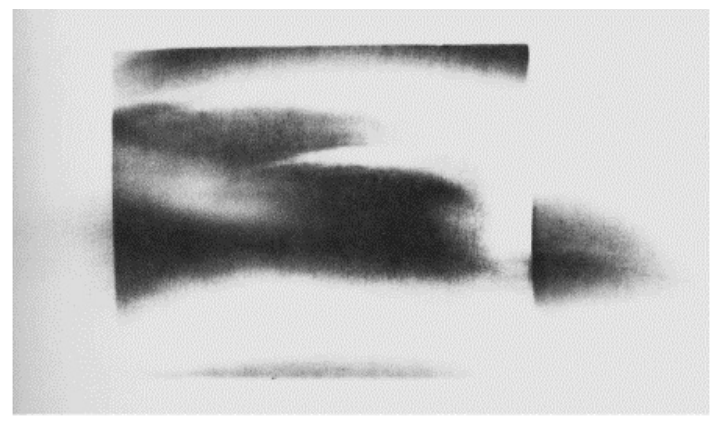

Melancolia -

luz violeta.

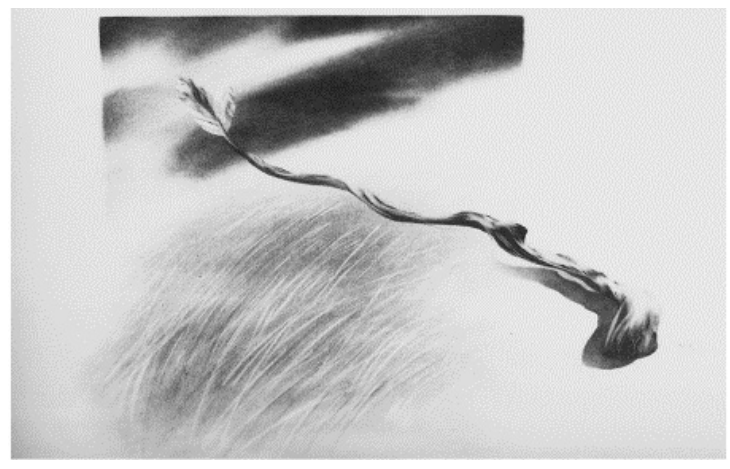

Mínima luz dos cardos. 
Pintar Macau e a Ilha dos Amores...

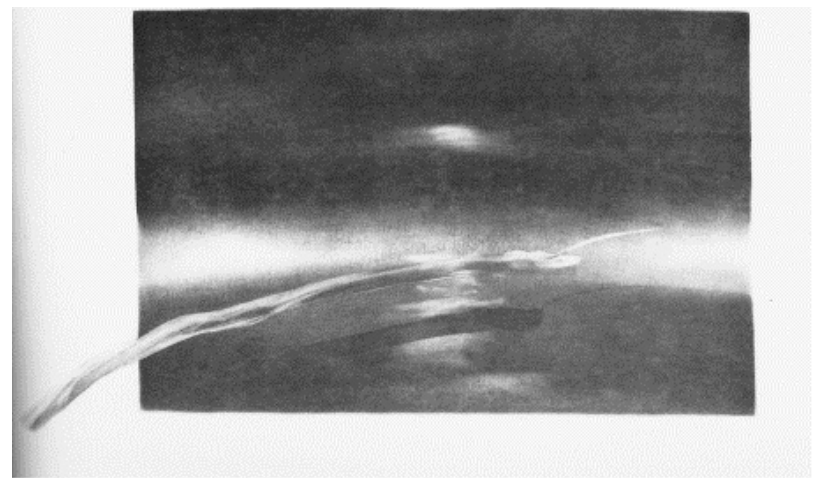

Manhã nua,

luz calada.

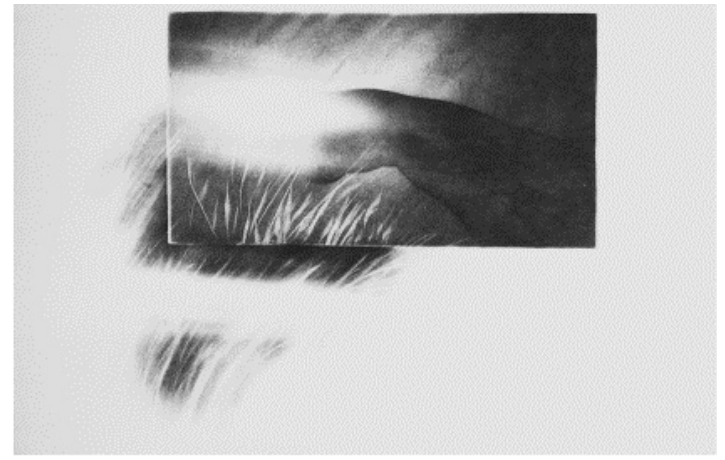

Rompe de noite a ilha

como o luto da alegria. 

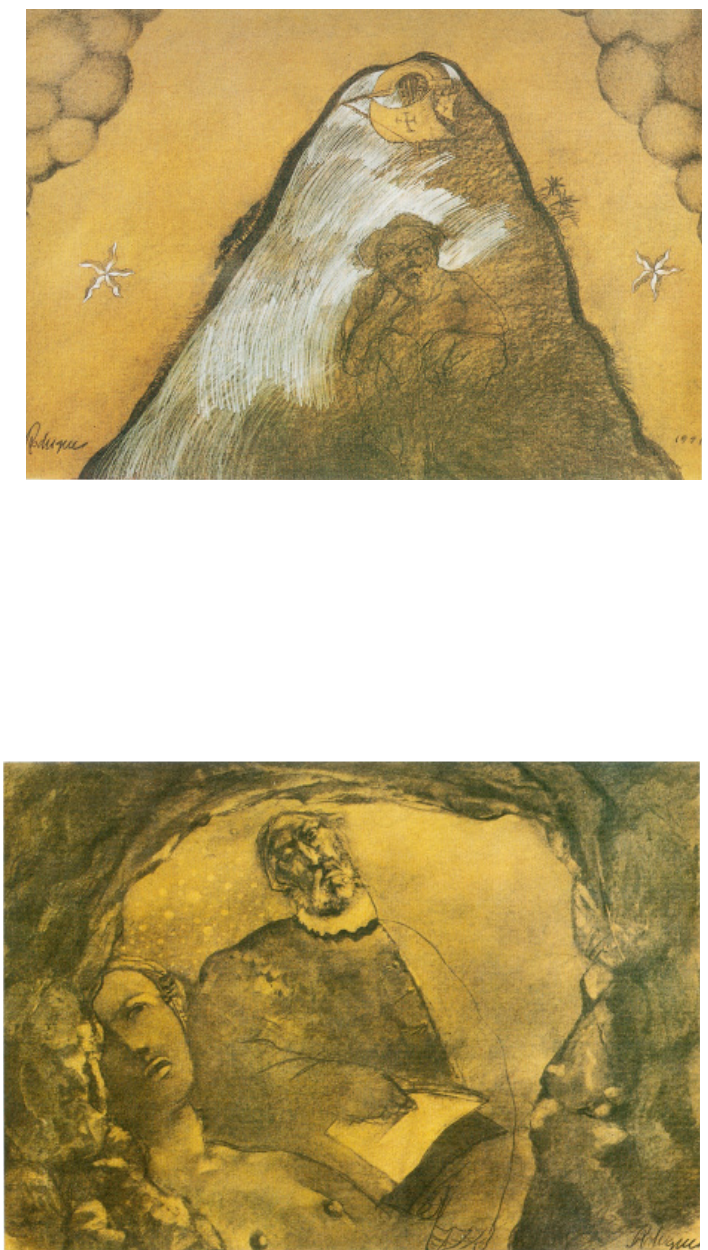
Pintar Macau e a Ilha dos Amores...
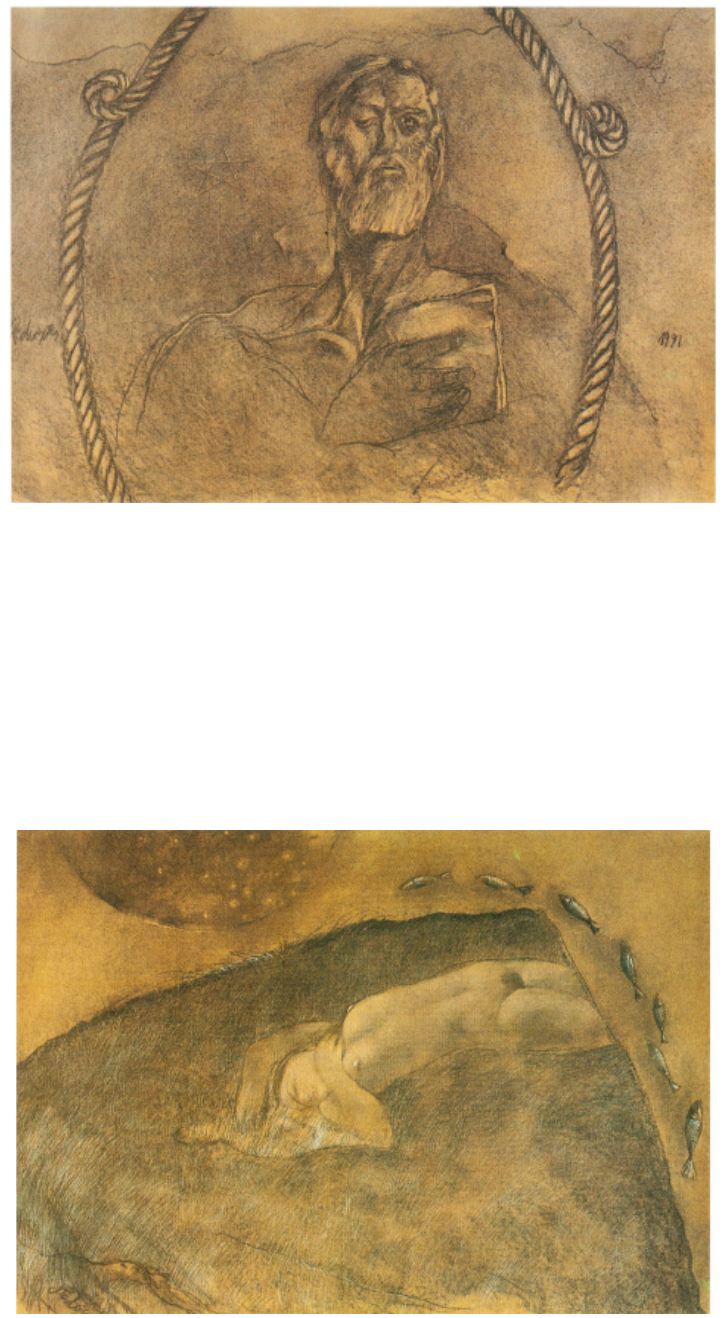

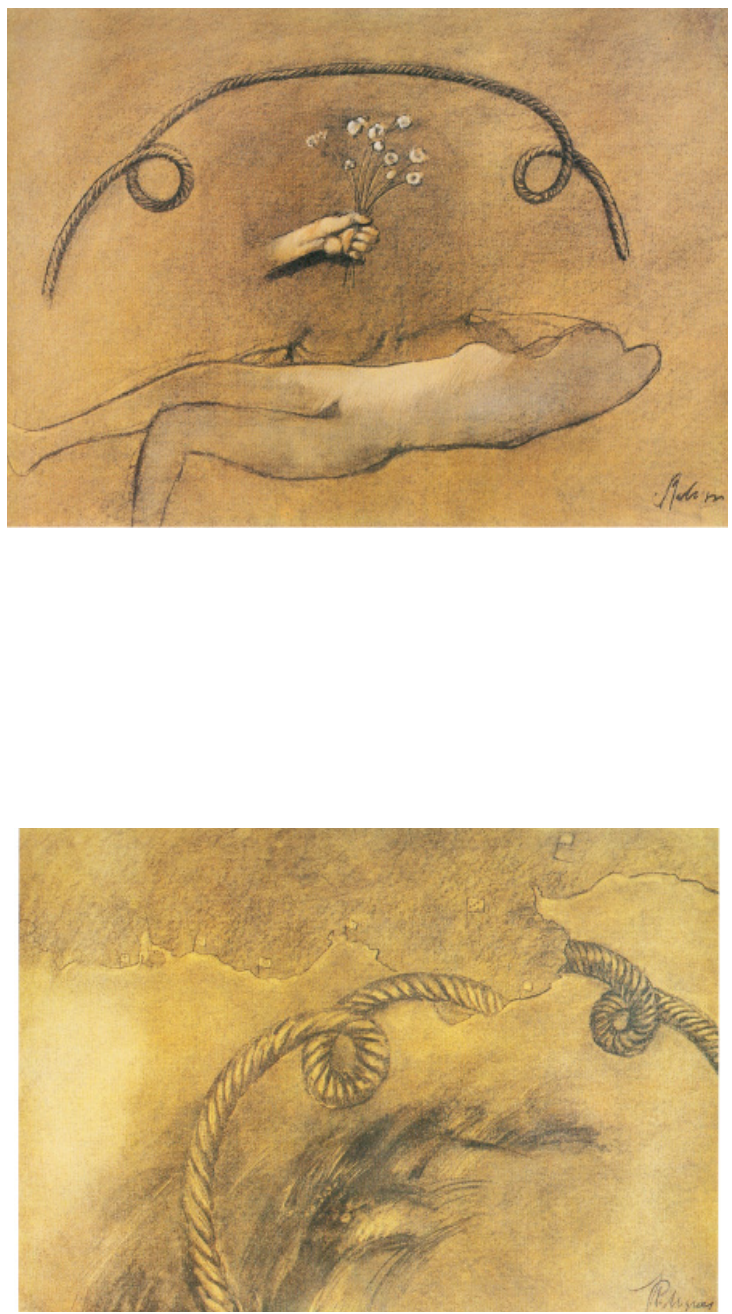
Pintar Macau e a Ilha dos Amores...
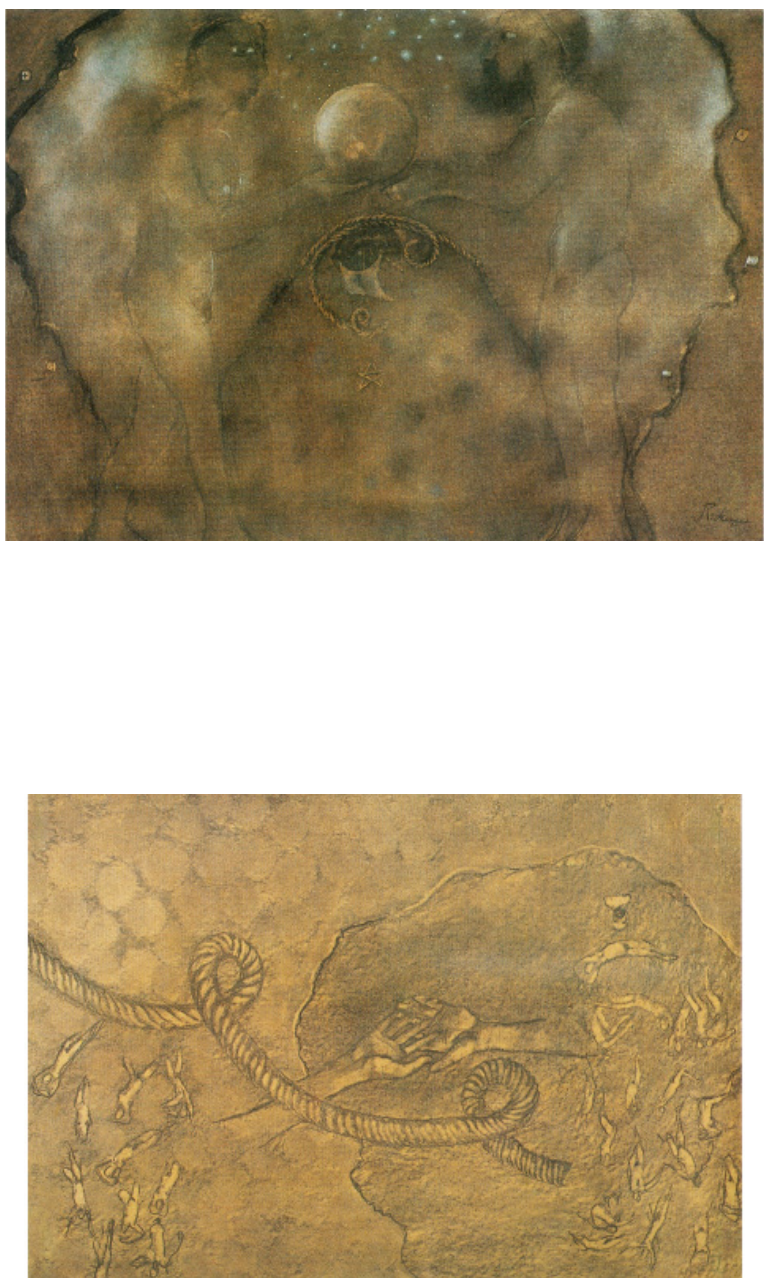

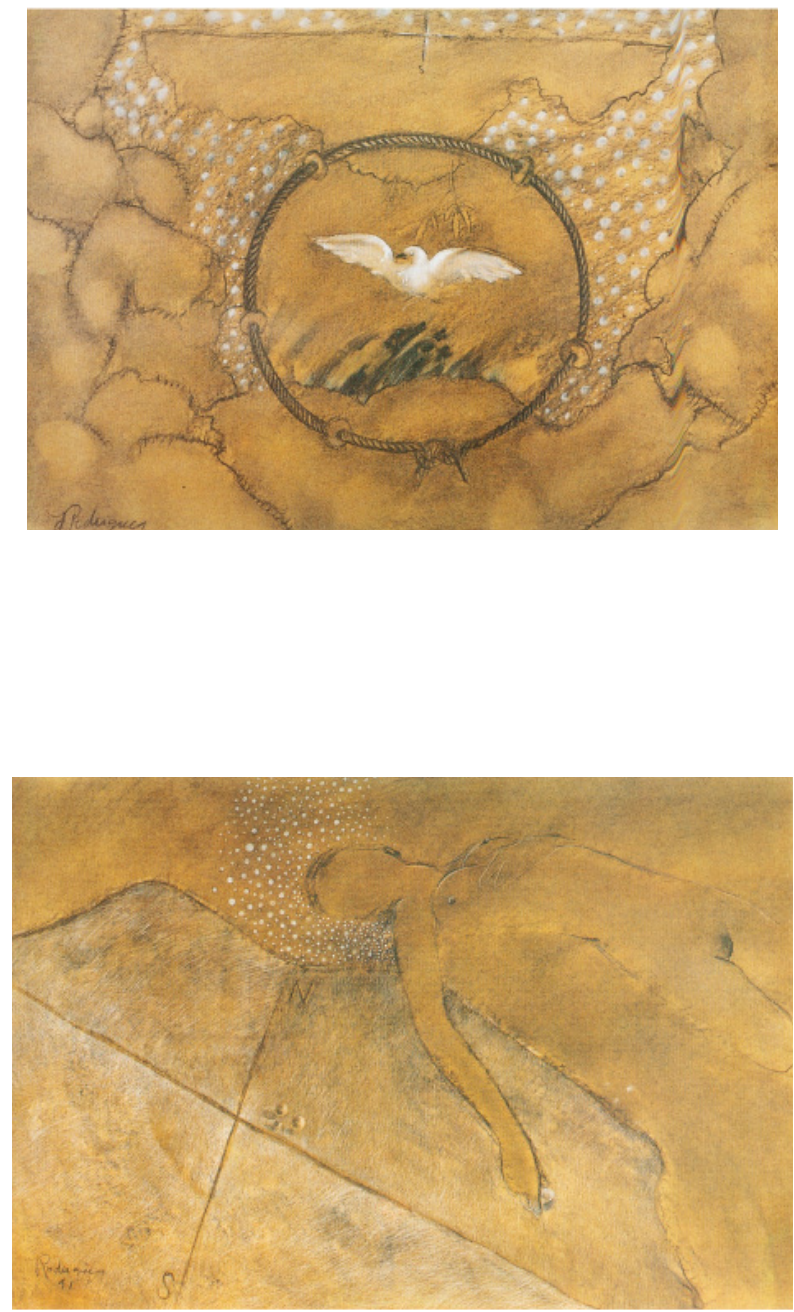
Pintar Macau e a Ilha dos Amores...
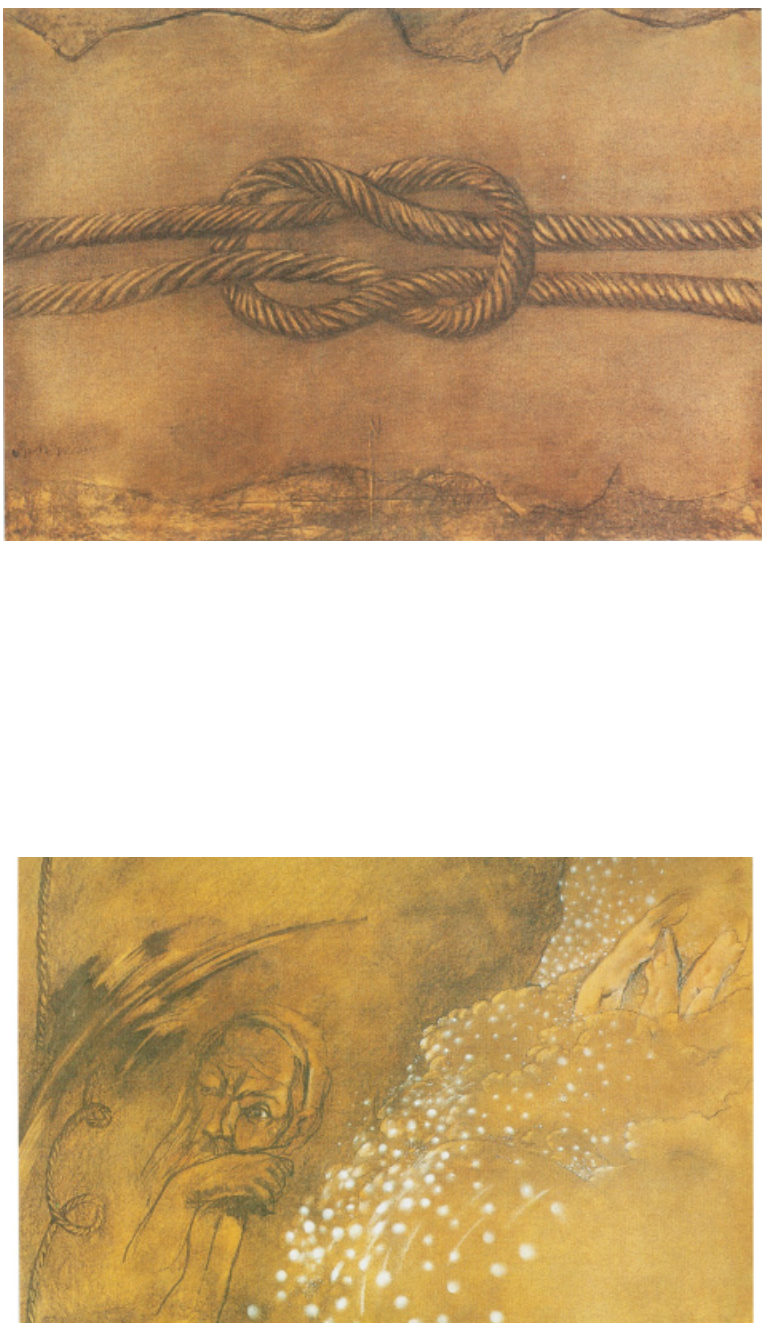

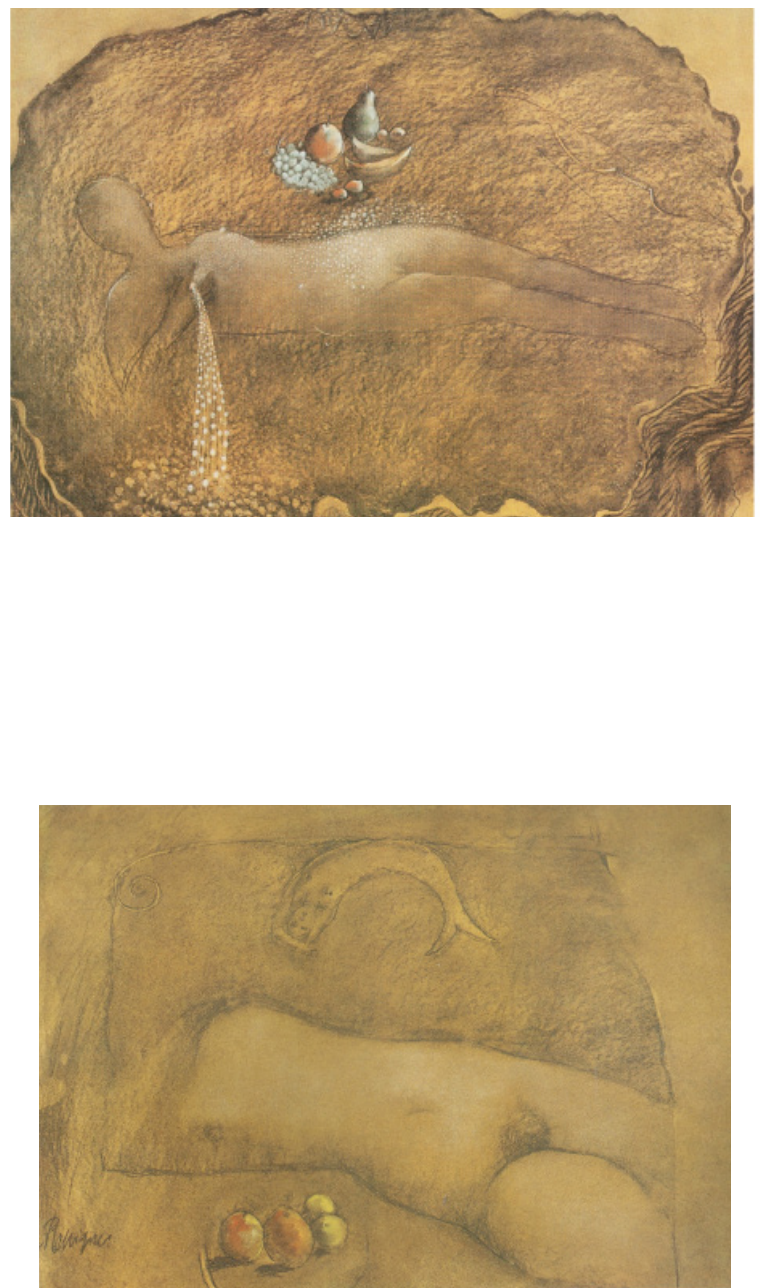
Pintar Macau e a Ilha dos Amores...
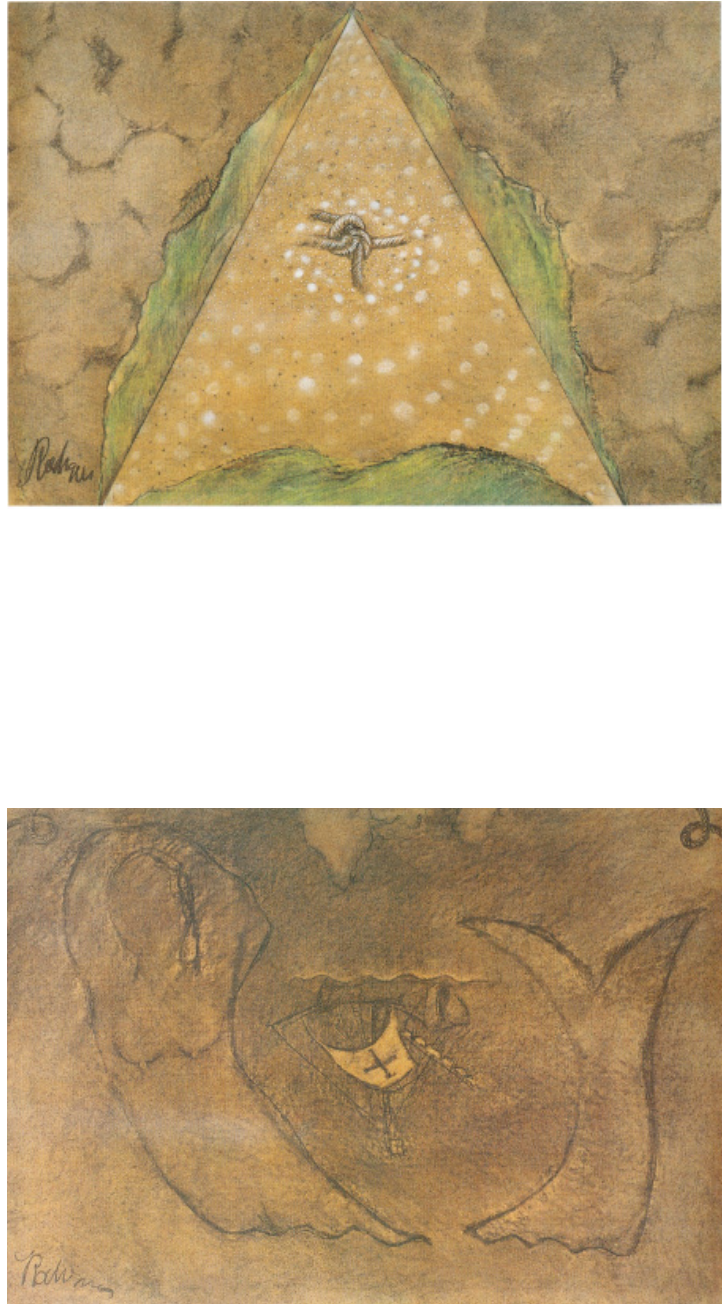


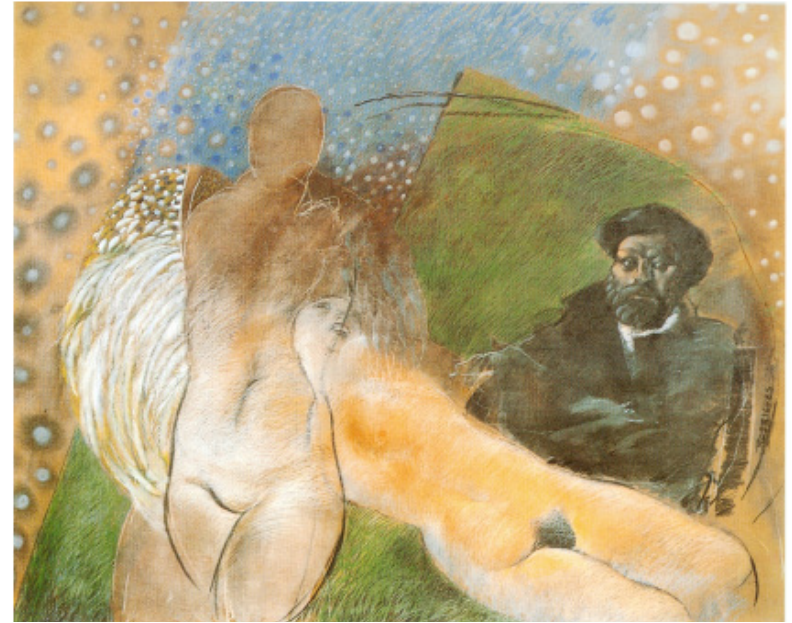

Lima, Isabel Pires de. Pintar Macau e a Ilha dos Amores: José Rodrigues e Luís de Camões (intermedialidades). In: Simas, Monica (Org.). Estudos sobre Macau e outros orientes. São Paulo: Paulistana, 2017. p. 280-318. 